\title{
Updating the taxonomy of the bee genus Megalopta (Hymenoptera: Apidae, Augochlorini) including revision of the Brazilian species
}

\author{
L.M. Santos* and G.A.R. Melo \\ Laboratório de Biologia Comparada de Hymenoptera, Departamento de Zoologia, Universidade \\ Federal do Paraná, Curitiba, PR, Brazil
}

(Received 14 August 2013; accepted 17 June 2014; first published online 2 September 2014)

\begin{abstract}
Megalopta (Smith 1853) is a nocturnal and/or crepuscular bee genus, with Neotropical distribution. The present work presents a taxonomic revision of Megalopta with emphasis on the Brazilian species through diagnosis and description of species and an identification key for most species that occur in South and Central America, with figures and distribution maps. Moreover eight new species are described: Megalopta guarani sp. n, M. mura sp. n, M. piraha sp. n, M. munduruku sp. n, M. yanomami sp. n, M. xavante sp. n, M. mapinguari sp. n. and Megalopta karitiana sp. n. Sex association for the male of M. chaperi (Vachal, 1904) is presented. Also we present taxonomical notes of valid species, with designation of lectotypes, new synonymies and checklist of valid species. Now, 32 valid species are recognized for the genus, with 19 in the Brazilian fauna. The present work enables correct identification of the species, which should facilitate further studies with Megalopta.

http://zoobank.org/urn:lsid:zoobank.org:pub:6DB510C5-259A-4A66-AB36-7745 AD4F53E9
\end{abstract}

Keywords: dim-light bees; Halictidae; neotropics; systematics; sweat bees; taxonomy

'Agora, imediatamente, é aqui que começa o primeiro sinal do peso do corpo que sobe. Aqui troco de mão e começo a ordenar o caos' (Cesar 1988).

'Instantly now, it is here that the first sign of the body begins, upwards. I then change gear, and begin to organize the chaos'. Free translation.

\section{Introduction}

Megalopta is a speciose genus within the bee tribe Augochlorini, with distribution from southern Brazil (state of Santa Catarina) to the state of Sinaloa, in Mexico (Michener 2007; Gonzalez et al. 2010). Currently, the genus has 30 valid species, most of them inhabiting the Amazon basin (Moure 2007; Santos and Silveira 2009; Engel 2011). Dating based on molecular analyses estimates that the genus diversification probably started in the Tertiary, with a range between 15 and 30 mya (Danforth et al. 2004; Tierney et al. 2012).

These relatively large halictine bees, with body length varying between 9 and $20 \mathrm{~mm}$, are conspicuous elements of the Neotropical wet forests. The species of Megalopta are well known for being obligate dim-light bees, with a specialized visual system that allows them to forage in twilight conditions, unlike diurnal bees (Greiner

*Corresponding author. Email: megalopta@gmail.com 
et al. 2004a, 2004b, 2005; Warrant et al. 2004; Wcislo and Tierney 2009; Baird et al. 2011; Berry et al. 2011). Due to their nocturnal behaviour, these bees can be easily captured by light traps, but can also be collected while visiting flowers with nocturnal or crepuscular anthesis, by Malaise traps and by traps baited with fragrances commonly used to attract male orchid bees (Knoll and Santos 2012).

Megalopta bees excavate their nests in dead wood, most frequently in fallen tree branches in the understorey (Janzen 1968; Wcislo et al. 2004; Tierney et al. 2008; Santos et al. 2010). The few species investigated are facultatively social, with nests containing up to 17 females and conspicuous variation in body size among females from a single nest. In these multifemale nests, dominating females are larger and coerce their subordinates to engage in trophallactic behaviour (Wcislo and Gonzalez 2006). Differences in female body size have been shown to depend on the amount of food received during larval development (Kapheim et al. 2011).

The main studies on the taxonomy of the genus are: Cockerell $(1900,1923)$, Ducke (1908, 1910), Schrottky (1906), Vachal (1904), Meade-Waldo (1916), Friese (1911,1923, 1926), Moure (1943, 1958), Michener and Moure (1964), Engel et al. (1997), Hinojosa-Diaz and Engel (2003), Engel (2006, 2011), Santos and Silveira (2009) and Gonzalez et al. (2010).

The genus was revised by Friese (1926), who included in it species currently placed in Megalopta proper, Megaloptidia Cockerell, 1900, Megommation Moure, 1943 and Xenochlora Engel, Brooks and Yanega, 1997. Although he dealt with almost all of the currently known species, the characters used in the identification key are extremely variable, which makes proper identification not reliable. In this context, Sakagami and Moure (1967) stated that it was virtually impossible to identify the species correctly, mainly due to female polymorphisms, involving macrocephalic and normal-headed females (Sakagami and Moure 1965). Janzen (1968) defined the taxonomy of the genus as chaotic and Engel $(2000,2006,2011)$ stated that the genus needed a modern revision and that many synonyms should exist, because new species described by authors in the first half of the twentieth century were based on extremely variable characters. An exception to the statement made by Engel is the work of Vachal (1904), who used structural characters with little intraspecific variation.

A few genus-group names have been proposed within Megalopta: Megaloptella Schrottky, 1906, for species with a distinct wing venation; Tmetocoelia Moure, 1943, for species whose males exhibits a mid longitudinal sulcus in the third sternum; and Noctoraptor Engel, Brooks and Yanega, 1997 proposed as a subgenus for cleptoparasitic species. Here, these three names are treated as junior synonyms of Megalopta, following Moure (2007).

The monophyly of Megalopta and its relationships with other genera of Augochlorini have been studied by Eickwort (1969), Danforth and Eickwort (1997) and Engel (2000). According to Engel (2000) the genus belongs to the clade named 'Megalopta group' (Xenochlora, (Megalopta, Noctoraptor)) and is supported by the broad distal labral process, the basal expansion of the distal labral keel, the formation of an acute angle by the epistomal sulcus that protrudes into the basal margin of the clypeus, the presence of the interocellar furrow, the shortened and declivitous basal area of the propodeum, and the use of wood substrate for nest construction (Engel 2000). However, a recent molecular analysis by Tierney et al. (2012) with three genes showed that Megalopta is paraphyletic, with Megalopta atra appearing as sister group of Xenochlora and separate from 
the remaining Megalopta. Only the analysis based in the gene for the longwavelength green opsin recovered a monophyletic Megalopta.

Previously to this study, 10 species were recorded from Brazil (Moure 2007; Santos and Silveira 2009): M. aegis Vachal, 1904; M. aeneicollis Friese, 1926; M. amoena (Spinola 1853); M. atlantica Santos and Silveira, 2009; M. cuprea Friese, 1911; M. guimaraesi Santos and Silveira, 2009; M. opacicollis Friese, 1926; M. purpurata Smith, 1879; M. sodalis Vachal, 1904 and M. sulciventris Friese, 1926. The present work revises most of the Brazilian fauna of Megalopta, and provides an identification key to the species found in Brazil and other South American countries, such as Bolivia, Ecuador, French Guiana, Guyana, Peru, Suriname, Venezuela and Trinidad and Tobago. Moreover, the study presents description of eight new species, lectotype designations, new synonymies, sex associations for the described species, comments on available names, and new morphological characters that improve the current knowledge of the genus. A checklist of all valid species in the genus is provided in Appendix 1.

\section{Material and methods}

For this study, more than 2500 specimens of Megalopta were examined. In addition to the material from the 'Coleção Entomológica Padre Jesus Santiago Moure', Universidade Federal do Paraná (DZUP), specimens were loaned from the following institutions and curators: CRC, Claus Rasmussen's private collection, Aarhus, Denmark; DZMG, Departamento de Zoologia, Universidade Federal de Minas Gerais, Belo Horizonte, Brazil - Dr. Fernando Amaral da Silveira; INPA, Instituto Nacional de Pesquisas da Amazônia, Manaus, Brazil Dr. Márcio Luiz de Oliveira; LEBIC, Laboratório de Ecologia e Biogeografia de Insetos da Caatinga - Fernando Zanella; MRRR, Museu Estadual de Roraima, Boa Vista, Brazil - Dr. Silvio José Reis da Silva; MUSM, Museo de Historia Natural, Universidad Nacional Mayor de San Marcos, Lima, Peru - Dr. Gerardo Lamas Müller; MEUFV, Museu Regional de Entomologia da Universidade Federal de Viçosa, Viçosa, Brazil - Dr. Lúcio Antônio de Oliveira Campos; MPEG, Museu Paraense Emílio Goeldi, Belém, Brazil - Dr. Orlando Tobias; MSNT, Museo Regionale di Scienze Naturale, Turin, Italy Dr. Luca Picciau; MZUSP, Museu de Zoologia da Universidade de São Paulo, São Paulo, Brazil - Dr. Carlos Roberto Brandão; SEMK, Snow Entomological Collection, Division of Entomology, Natural History Museum, University of Kansas, Lawrence, USA - Dr. Zachary Falin; RMNH, Nationaal Natuurhistorisch Museum, Leiden, Netherlands - Dr. Ing. C. van Achterberg; UFBA, Laboratório de Ecologia da Polinização, da Universidade Federal da Bahia, Salvador, Brazil - Dr. Mauro Ramalho; UFPB, Laboratório de Entomologia da Universidade Federal da Paraíba, João Pessoa, Brazil - Dr. Celso Feitosa Martins; ZMB, Museum für Naturkunde, Berlin, Germany - Dr. Frank Koch Berlin, Germany. Additional institutions mentioned in the work are: AMNH, American Museum Natural of History, New York, USA; BLCU, Utah State University, Bee Biology and Systematics Laboratory, Utah, Logan, USA; BMNH, Natural History Museum, London, UK; CUIC, Cornell University, Ithaca, New York, USA; MNHP, Muséum National d'Historie Naturelle, Paris, France; SNCBSH, State of North Carolina Biological Station, North 
Carolina, USA; and STRI, Smithsonian Tropical Research Institute, Balboa, Panama. The specimens of Megalopta collected in the pollination study of Parkia velutina (Hopkins et al. 2000) could not be studied, because they were not located in the INPA collection.

The terminology for the external morphology follows Eickwort (1969) and Michener (2000, 2007), except for the scutum, here referred to as mesoscutum, and the 'basal area of propodeum', here the metapostnotum, following Brothers (1976). The following abbreviations are used: F1-F11 for the flagellomeres; T1-T6, metasomal terga; and S1-S8, metasomal sterna. The punctation density is described in relation to the interspaces between punctures, measured in terms of puncture diameter (pd). Measurements of metanotum and basal area of metapostnotum were taken at their midline. The surface of the basal area of metapostnotum is defined as rugulose when possessing minute and fine rugulosities, or polished when shiny and lacking microsculpture. The longitudinal rugulosities are considered long when extending to posterior margin of basal area of metapostnotum, and short when not extending to the posterior margin. The mandible of nonparasitic species is bidentate, with a ridge on its inner surface forming two short supplementary inner teeth (Engel et al. 1997), while in the parasitic species the mandible is simple and lacks supplementary teeth.

The measurements presented, all in millimetres, are: approximate body length, maximum width of head, intertegular distance, length of forewing with tegula, and length of forewing. Measurements are not provided for Megalopta purpurata because the holotype was examined only through photographs.

In the description of species, the variable characters are marked by asterisks and are discussed below in the item 'Comments'. In the item 'Examined material', all label data are transcribed, with information from each label presented between quotation marks, and the different lines in the label by a backslash (I).

Specimens were photographed using a Leica DFC 500 camera attached to a Leica MZ16 stereomicroscope (Leica, Germany), and images were treated using the software Auto-Montage Pro (Syncroscopy) of the Projeto Taxon line, Rede Paranaense de Coleções Biológicas da Universidade Federal do Paraná (DZUP). Some of the photographs presented here appeared previously in Santos and Silveira (2009).

The geographical coordinates (latitude, longitude), when absent in the original labels were obtained through GeoLoc at http://splink.cria.org.br/geoloc? criaLANG=pt and Global Gazetteer Version 2.1 at www.fallingrain.com/world/. The distribution maps were prepared in ArcView ${ }^{\circledR}$ (ESRI, http://www.esri.com/). In the item 'Distribution' additional distribution records were taken from Moure (2007) and Santos and Silveira (2009), based on specimens not examined in this study.

Megalopta Smith, 1853

Megalopta Smith, 1853: 83. Type species: Megalopta idalia Smith, 1853.

Megalopta (Megaloptella) Schrottky, 1906: 312. Type species: Halictus ochrias Vachal, 1904.

Tmetocoelia Moure, 1943: 481. Type species: Megalopta sulciventris Friese, 1926.

Megalopta (Noctoraptor) Engel et al. 1997: 12. Type species: Megalopta byroni Engel et al. 1997. 


\section{Diagnosis}

Megalopta differs from other augochlorines, including Xenochlora, by the large ocelli and the closely packed series of hamuli in the hind wing (Engel 2000; Michener 2007), as well as in the morphology of the male S3-S5 (Santos and Melo 2013). Megalopta and Xenochlora differ from most augochlorines for their non-metallic, pale brown metasoma. A pale metasoma is present in Megaloptidia Cockerell, Megommation Moure, and some species of Megaloptina Eickwort, but these genera have a very slender proboscis, with the prementum 10 to over $20 \times$ as long as broad, and except for Megaloptina, also a serrate inner metatibial spur, while in Megalopta and Xenochlora the proboscis is not so slender, with the prementum about $4-8 \times$ as long as broad, and the inner metatibial spur is pectinate.

Three main lineages are recognized in the genus, the first one formed by the cleptoparasitic species, corresponding to the subgenus Noctoraptor, and treated here as the byrony group, the second one formed by the species in which the males have a conspicuous large process covered with velvety pilosity in the posterior upper margin of the metepisternum, and the last lineage comprises those species lacking a welldeveloped metepisternal process (Santos and Melo, unpublished data). The species of the second and third lineages can be further subdivided in four species groups: aegis, amoena, yanomami and sodalis. A subgeneric classification is not adopted here because the available name Megaloptella applies only to the amoena species group and Tmetocoelia has been shown to form a paraphyletic assemblage (Santos and Melo, unpublished data).

\section{Identification key to the species of Megalopta from Brazil}

This key includes species that occur in other South American countries (Bolivia, Ecuador, French Guiana, Guyana, Nicaragua, Peru, Suriname, Trinidad and Tobago, and Venezuela) and in Central America.

\section{Females}

1. Posterior upper margin of metepisternum modified into a conspicuously large process covered with velvety pilosity (Figure 1A, B)

- Posterior upper margin of metepisternum unmodified, lacking a velvety process (Figure 1C)

2 (1). Posterior margin of basal area of metapostnotum arcuate, gradually curved toward the metanotum laterally, the longitudinal rugulosities sometimes numerous and present laterally (Figure 1D); upper frons conspicuously convex, strongly declivous toward sulcus around median ocellus (Figure 1E)... aegis group

- Posterior margin of basal area of metapostnotum straight, abruptly bending laterally toward the metanotum, the longitudinal rugulosities restricted to mid portion, absent laterally (Figure 1F); upper frons flat, not strongly declivous toward sulcus around median ocellus (Figure 2A)... amoena 

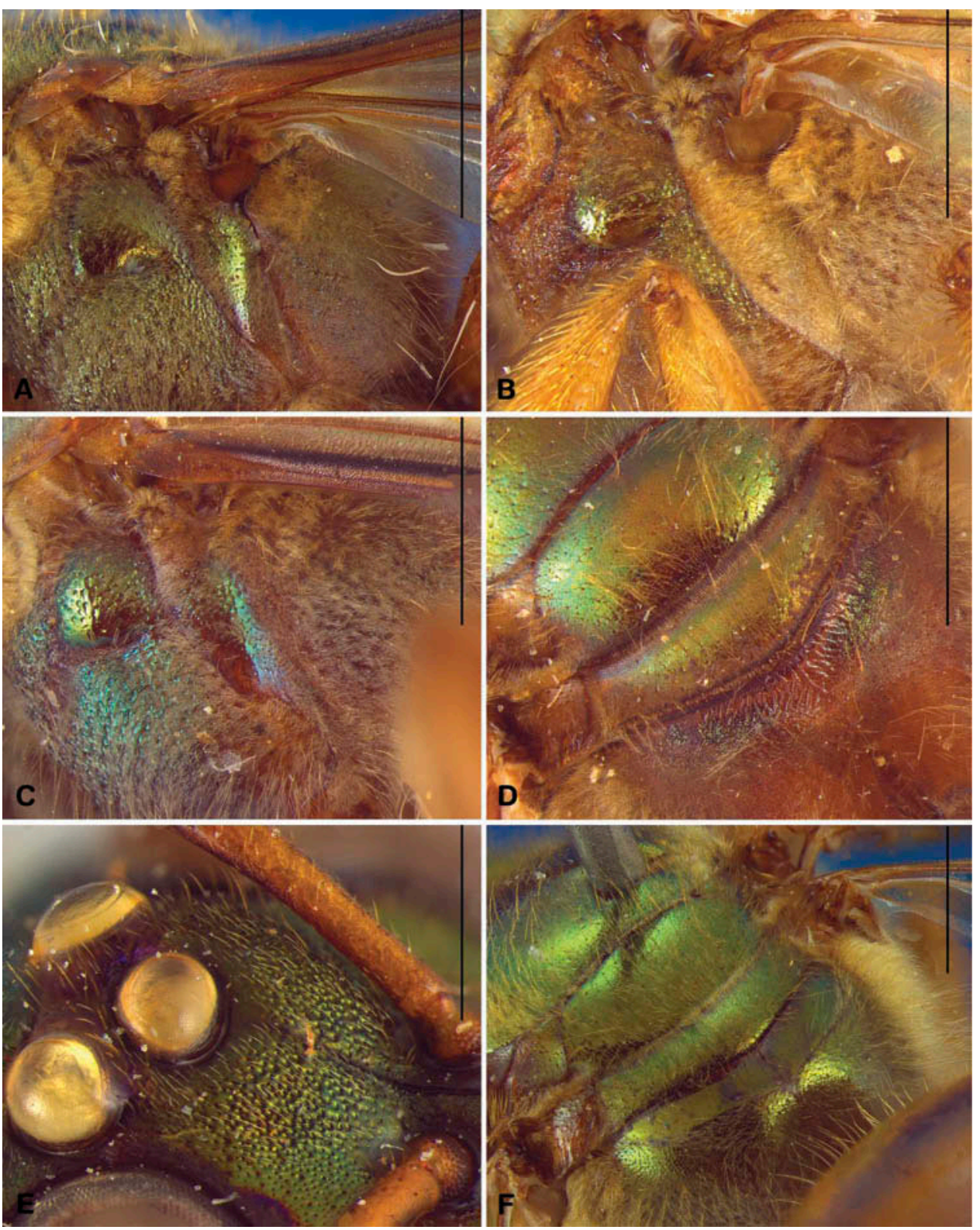

Figure 1. Females of Megalopta. (A-C) Lateral view of mesosoma; (A) M. aeneicollis Friese from Novo Airão, Brazil; (B) M. mura sp. n. from Manaus, Brazil; (C) Megalopta yanomami sp. n. from Parauapebas, Brazil; (D, F) posterolateral view of mesosoma; (D) M. sulciventris Friese from Manaus, Brazil; (E) lateral view of head of M. aegis Vachal from Caldas Novas, Brazil; (F) M. guimaraesi Santos \& Silveira from Alto Paraíso de Goiás, Brazil. Scale bar 1 $\mathrm{mm}$, except in part $\mathrm{E}$ scale bar $0.5 \mathrm{~mm}$. 

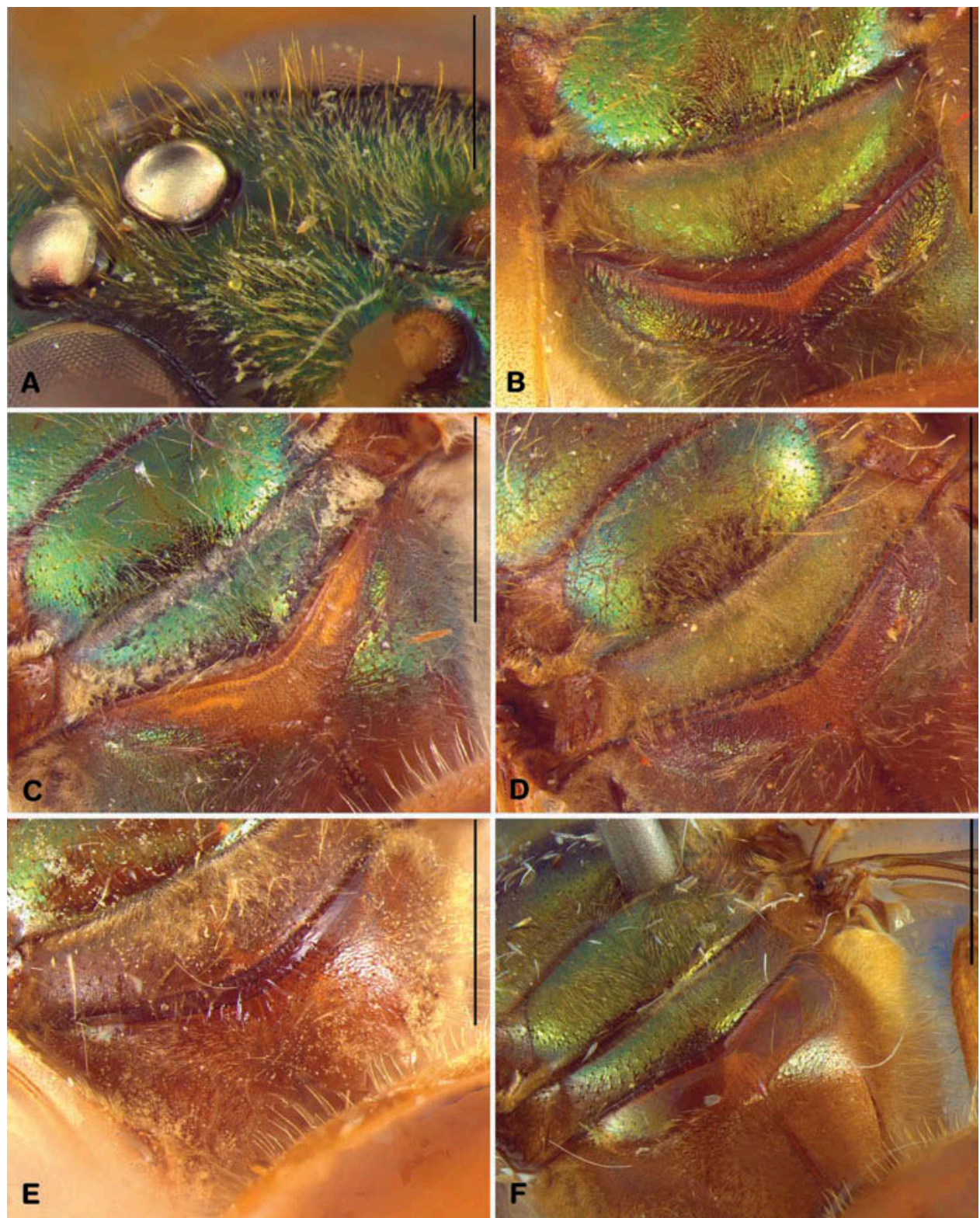

Figure 2. Females of Megalopta. (A) Lateral view of head of M. guimaraesi Santos \& Silveira from Alto Paraíso de Goiás, Brazil; (B-F). posterolateral view of mesosoma; (B) M. nitidicollis Friese from Rio Branco, Brazil; (C) M. aeneicollis Friese from Novo Airão, Brazil; (D) $M$. aegis Vachal from Caldas Novas, Brazil; (E) M. chaperi Vachal from Amajari, Brazil; (F) $M$. amoena Spinola from Alenquer, Brazil. Scale bar $1 \mathrm{~mm}$. 
3 (2). Basal area of metapostnotum with longitudinal rugulosities weakly impressed medially and more developed laterally, the integument often reddish brown on basal half and metallic green on apical half (Figure 2B)

M. nitidicollis

- Basal area of metapostnotum with weak longitudinal rugulosities along its entire surface (Figures 1D, 2C, D)

4 (3). Basal area of metapostnotum orangish, without metallic reflections, surface entirely finely rugulose, stronger rugulosities rectilinear and long along entire surface (Figure 2C)

M. aeneicollis

- Basal area of metapostnotum reddish brown or metallic green, the longitudinal rugulosities imbricated laterally (Figures 1D, 2D) 5

5 (4). Metanotum with dense short plumose pilosity, present on entire surface and obscuring the integument in oblique view (Figure 2D); basal area of metapostnotum with the integument entirely reddish brown, sometimes with green highlights laterally (Figure 2D)

M. aegis

- Metanotum sometimes with pilosity short and plumose, present only in two-thirds of disc, not obscuring the integument in oblique view (Figure 1D); basal area of metapostnotum with the integument metallic green with strongly imbricated longitudinal rugulosities (Figure 1D)

M. sulciventris

6 (2). Basal area of metapostnotum very short, about one-third as long as metanotum (Figure 2E) M. chaperi

- Basal area of metapostnotum longer, about as long as or only slightly shorter than metanotum (Figures 1F, 3A)

7 (6). Basal area of metapostnotum uniformly metallic green (Figure 1F); mesoscutum, adjacent to parapsidial line, densely punctured $(<1 \mathrm{pd})$, punctation sparser in direction to mesoscutal lip ( $\geq 1 \mathrm{pd}$ ) (Figure $3 \mathrm{~B}$ ); scutellum with posterior margin levelled to anterior margin of metanotum (Figure $3 \mathrm{C}$ )

M. guimaraesi

- Basal area of metapostnotum often reddish brown medially and metallic green laterally (Figure 3A); mesoscutum, adjacent to parapsidial line, with very dense contiguous punctation, in direction to mesoscutal lip punctures separated by $<1$ pd (Figure 3D); scutellum with posterior margin raised in relation to anterior margin of metanotum (Figure $3 \mathrm{E}$ ) ....

M. mura sp. n.

8 (1). Basal area of metapostnotum smooth laterally (Figures $2 \mathrm{~F}, 3 \mathrm{~F}, 4 \mathrm{~A}-\mathrm{C}$ ) ... 9

- Basal area of metapostnotum microreticulated laterally (Figure 4D, E)... sodalis group 13

9 (8). Mandible simple and lacking supplementary teeth; ocellocular distance longer than F1 length (Figure 4F); scopa absent; basitibial plate with undefined margins (Figure 5A)

M. xavante sp. $\mathrm{n}$.

- Mandible bidentate and with supplementary teeth; ocellocular distance shorter than F1 length (Figure 5B); scopa present; basitibial plate with defined margin (Figure 5C) 10 

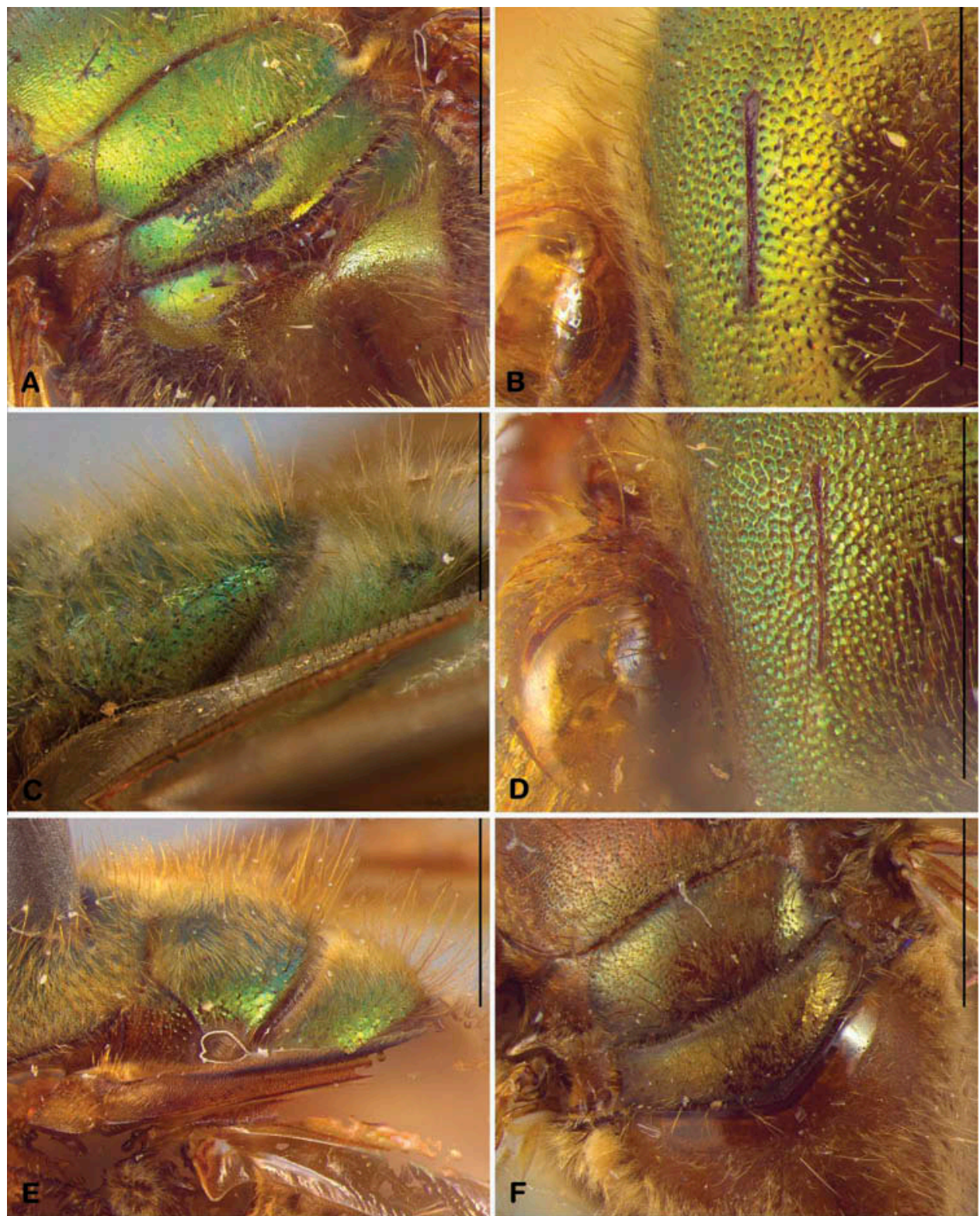

Figure 3. Females of Megalopta. (A, F) Posterolateral view of mesosoma; (B, D) dorsal view of mesoscutum; (C, E) lateral view of mesosoma; (A) M. mura sp. n. from Manaus, Brazil; (B, C) M. guimaraesi Santos \& Silveira from Alto Paraíso de Goiás, Brazil; (D, E) M. mura sp. n. from Manaus, Brazil; (F) M. xavante sp. n. (holotype) from Nova Xavantina, Brazil. Scale bar $1 \mathrm{~mm}$. 

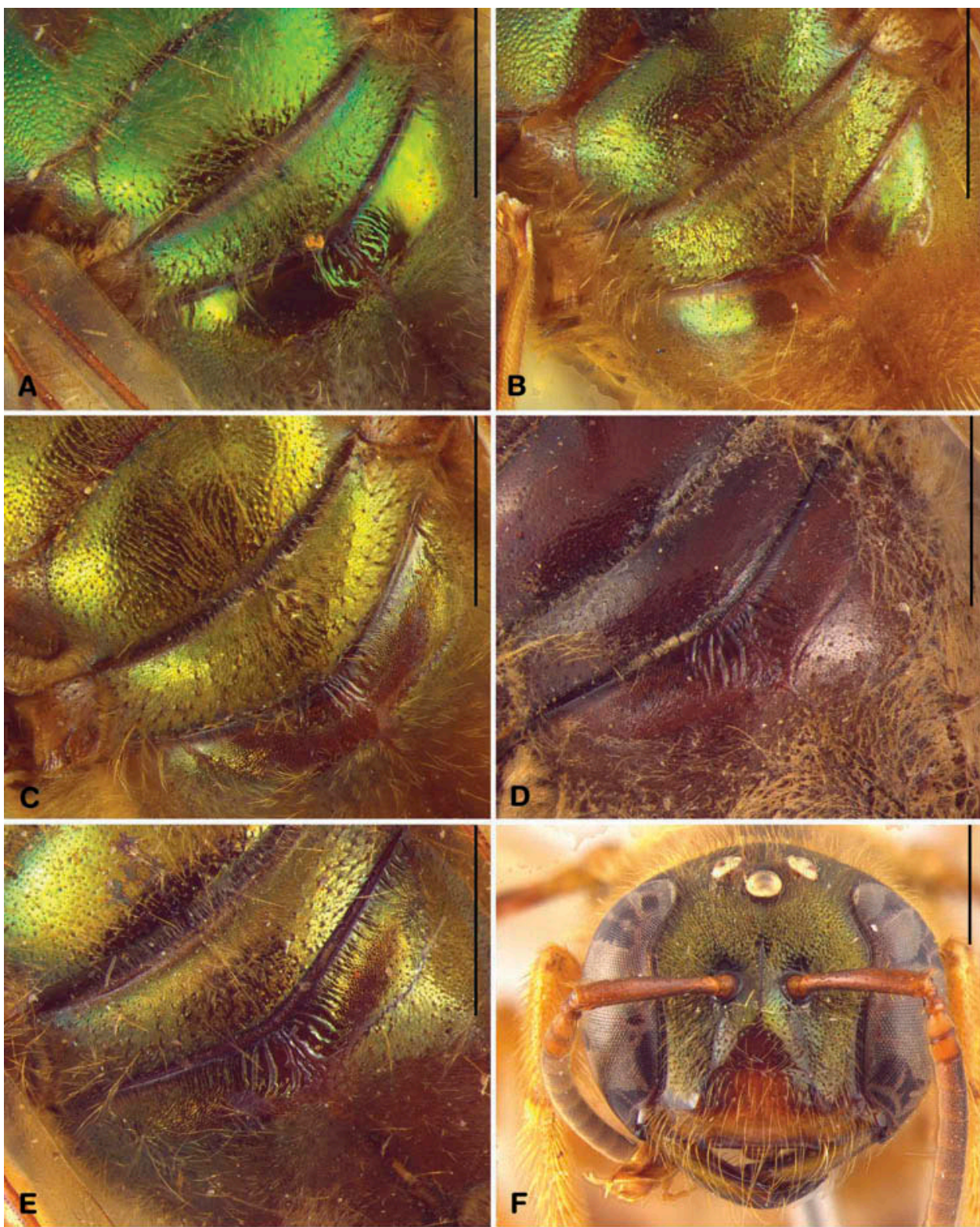

Figure 4. Females of Megalopta. (A-E) Posterolateral view of mesosoma; (A) Megalopta yanomami sp. n. from Parauapebas, Brazil; (B) M. piraha sp. n. from Manaus, Brazil; (C) M. munduruku sp. n. from Belterra, Brazil; (D) M. cuprea Friese from Nigrillani, Bolivia; (E) M. sodalis Vachal from Antonina, Brazil; (F) frontal view of head of M. xavante sp. $\mathrm{n}$ from Nova Xavantina, Brazil. Scale bar $1 \mathrm{~mm}$. 

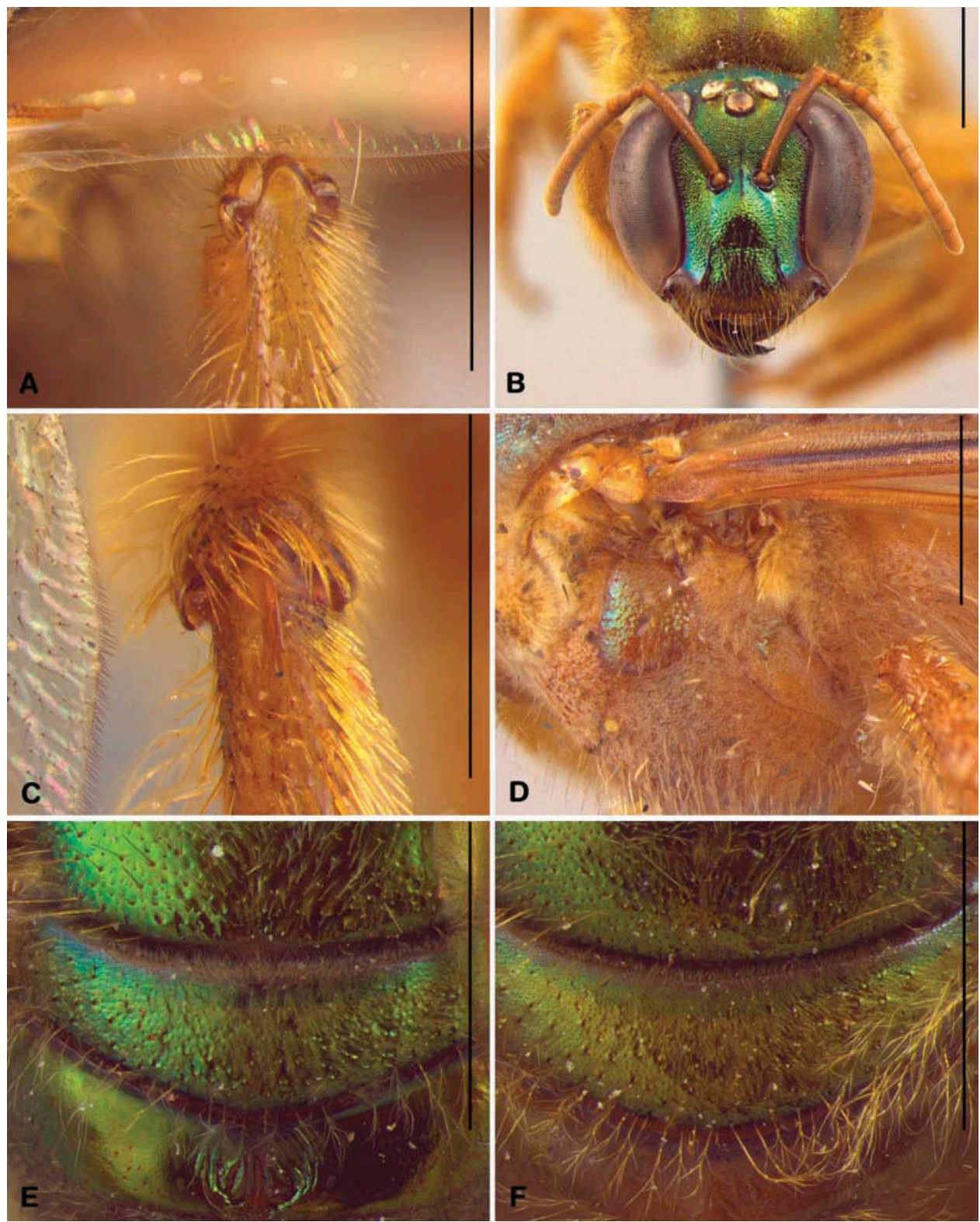

Figure 5. Females of Megalopta. (A, C) Lateral view of basitibial plate; (A) Megalopta xavante sp. n. from Nova Xavantina, Brazil; (B) frontal view of head in the female of $M$. piraha sp. n. from Manaus, Brazil; (C) M. piraha sp. n. from Manaus, Brazil; (D) lateral view of mesosoma of $M$. amoena from Alenquer, Brazil; (E, F) dorsal view of mesosoma; (E) $M$. yanomami sp. n. from Parauapebas, Brazil; (F) M. piraha sp. n. from Manaus, Brazil. Scale bar $1 \mathrm{~mm}$. 
10 (9). Basal area of metapostnotum without longitudinal rugulae (Figure 2F); metepisternum usually with dense pilosity obscuring at the least upper half of sclerite (Figure 5D)

\section{M. amoena}

- Basal area of metapostnotum with longitudinal rugulae (Figure 4A-C); metepisternum with sparse pilosity, integument not obscured by pubescence (Figure 1C)... yanomami group

11 (10). Basal area of metapostnotum with longitudinal rugulosities restricted to mid portion, external rugulosities strongly impressed and forming semicircles, integument often dark green (Figure 4A); metanotum with contiguous punctation (Figure 5E); T1 densely punctured $(<1 \mathrm{pd})$...... M. yanomami sp. n.

- Basal area of metapostnotum without defined external sulcus delimiting the longitudinal rugulosities, integument light green (Figure 4B); metanotum often densely punctured $(<1 \mathrm{pd}$ ) (Figure $5 \mathrm{~F}$ ); T1 with sparse punctation $(\geq 1 \mathrm{pd})$

M. piraha sp. $\mathrm{n}$.

12 (8). Basal area of metapostnotum with mid depression restricted to anterior half, not extending to posterior margin (Figure 4C) M. munduruku sp. n.

- Basal area of metapostnotum with mid depression extending to posterior margin

13(12). Head and thorax mostly dark brown, lacking metallic reflections (Figure 4D) M. cuprea

- Head and thorax metallic green (Figure 4E) M. sodalis

Males

1. Posterior upper margin of metepisternum modified into a conspicuously large process covered with velvety pilosity (Figure 6A)

- Posterior upper margin of metepisternum unmodified, lacking a velvety process (Figure 6B)

2 (1). Posterior margin of basal area of metapostnotum arcuate, gradually curved toward the metanotum laterally, longitudinal rugulosities sometimes numerous and present laterally (Figure 6C-F); pilosity of metepisternum sparse, not obscuring the integument; diameter of velvety metepisternal process about $0.5 \times$ the tegula length (Figure 6A); 1st and 2nd tarsomere of foreleg with longest simple setae longer than summed length of the three apical tarsomeres; longitudinal sulcus of S3 strongly impressed (Figure 7A)... aegis group

- Posterior margin of basal area of metapostnotum straight, abruptly bending laterally toward the metanotum, the longitudinal rugulosities restricted to mid portion, absent laterally (Figure 7B, E); pilosity of metepisternum dense, obscuring the integument; diameter of velvety metepisternal process about $0.75 \times$ tegula length (Figure 7F); 1st and 2nd tarsomere of foreleg with longest simple setae smaller than summed length of the three apical tarsomeres; S3 lacking a longitudinal sulcus or sulcus only weakly indicated (Figure $8 \mathrm{~A}-\mathrm{C}) \ldots$ amoena group 

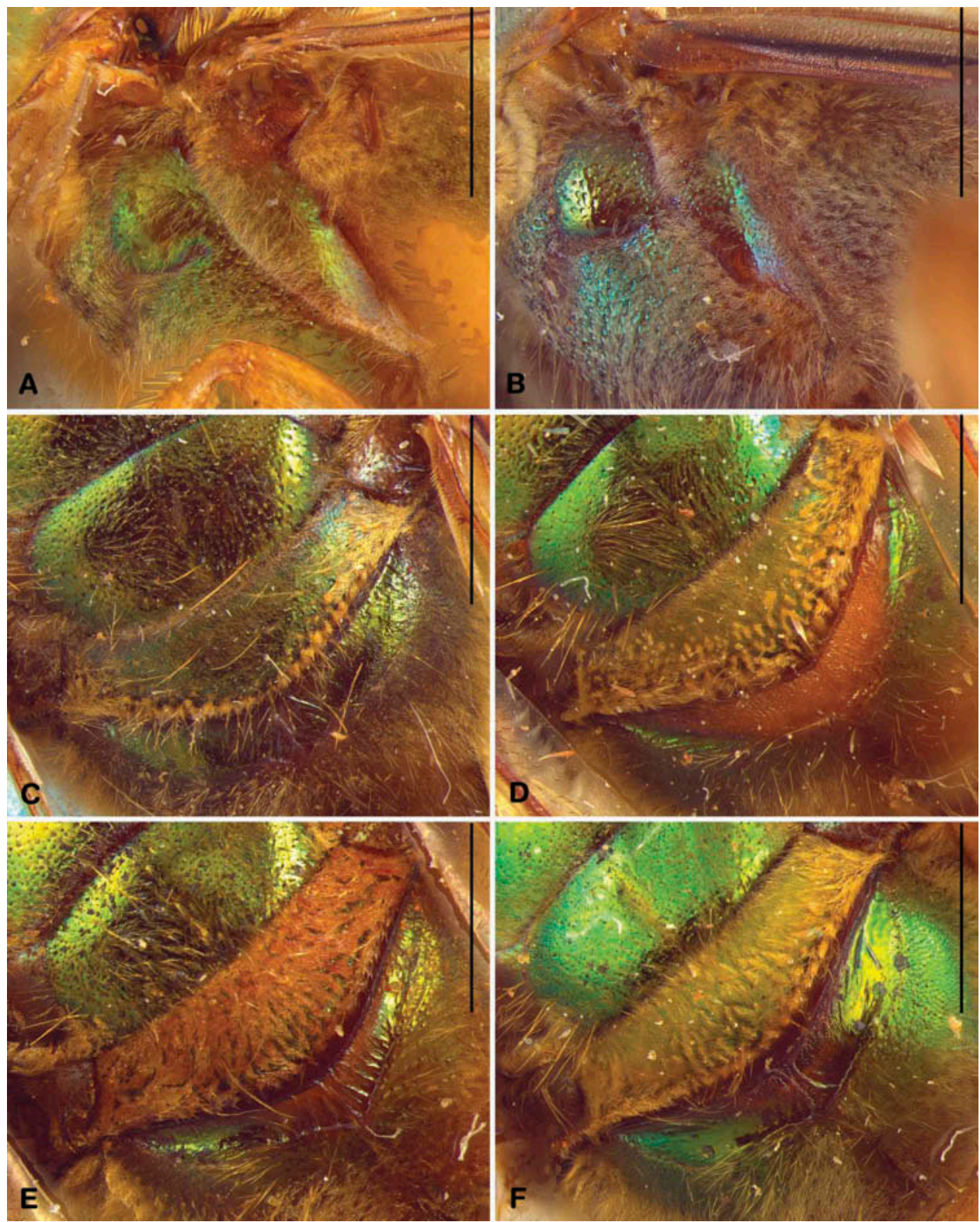

Figure 6. Males of Megalopta. (A, B) Lateral view of mesosoma; (A) M. aeneicollis Friese from Manaus, Brazil; (B) M. yanomami sp. n. from Parauapebas, Brazil; (C-F) posterolateral view of mesosoma; (C) M. sulciventris Friese from Manaus, Brazil; (D) M. aeneicollis Friese from Manaus, Brazil; (E) M. aegis Vachal from Caldas Nova, Brazil; (F) M. nitidicollis Friese from São Paulo de Olivença, Brazil. Scale bar $1 \mathrm{~mm}$. 

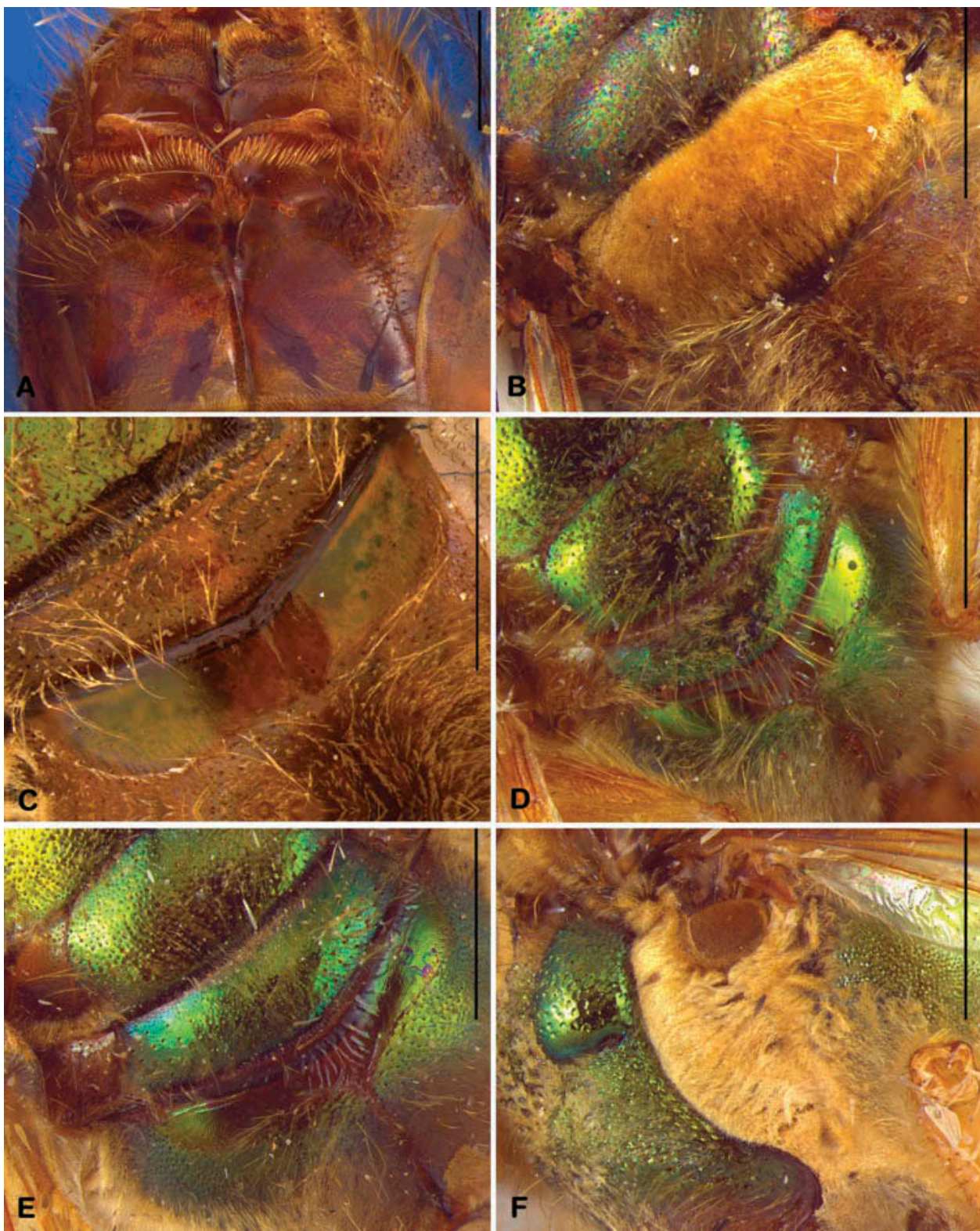

Figure 7. Males of Megalopta. (A) Ventral view of sternum 3-6 of M. aegis Vachal from Caldas Novas, Brazil; (B-E) posterolateral view of mesosoma; (B) M. chaperi Vachal from Amajari, Brazil; (C) M. amoena Spinola from Alenquer, Brazil; (D) M. guimaraesi Santos \& Silveira from Formosa, Brazil; (E) Megalopta mura sp. n. from Presidente Figueiredo, Brazil; (F) lateral view of mesosoma M. mura sp. n. from Ouro Preto do Oeste, Brazil. Scale bar $1 \mathrm{~mm}$. 

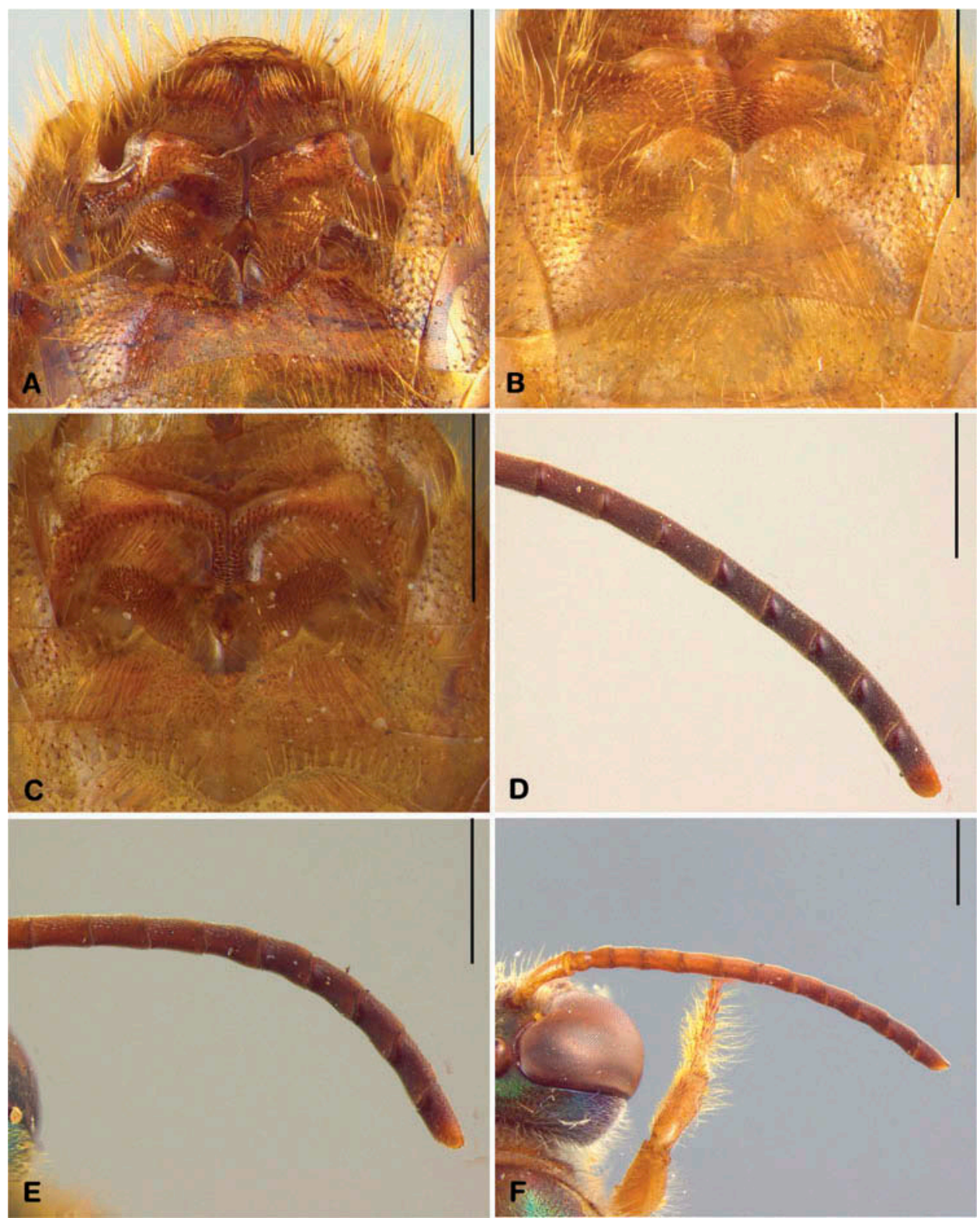

Figure 8. Males of Megalopta. (A-C) Ventral view of sternum 3-4; (A) M. chaperi Vachal Amajari, Brazil; (B) M. amoena Spinola from Alenquer, Brazil; (C) M. mura sp. n. from Parauapebas, Brazil; (D, E) Dorsal view of posterior surface of F6-F11; (D) M. sulciventris Friese from Manaus, Brazil; (E) M. aegis Vachal from Parauapebas, Brazil; (F) dorsal view of flagellum of $M$. amoena from Alenquer, Brazil. Scale bar $1 \mathrm{~mm}$. 
3 (2). Glabrous basal portion of F6-F11 raised in relation to remainder of flagellomere surface (Figure 8D); pilosity of metanotum restricted to two-thirds of disc, not obscuring the integument in oblique view (Figure 6C); basal area of metapostnotum entirely metallic green or sometimes reddish brown medially (Figure 6C)

M. sulciventris

- Glabrous basal portion of F6-F11 levelled to remainder of flagellomere surface (Figure 8E); metanotum often with very dense pilosity covering entire disc and obscuring the integument in oblique view (Figure 6D, F); basal area of metapostnotum reddish brown, orangish or reddish brown with metallic green, never entirely metallic green (Figure 6D, F)

4 (3). Surface of basal area of metapostnotum entirely finely rugulose, its posterior margin slightly raised but not forming a carina (Figure 6D)

M. aeneicollis

- Surface of basal area of metapostnotum variable, its posterior margin forming a carina (Figure 6E, F)

5 (4). Basal area of metapostnotum with strongly impressed longitudinal rugulosities along its entire surface, lateral portions with only short rugulosities (Figure 6E) M. aegis

- Basal area of metapostnotum lacking longitudinal rugulosities or only with a few weak rugulosities in its mid portion (Figure 6F)

M. nitidicollis

6 (2). Metanotum with dense pilosity; mid portion of basal area of metapostnotum very short, about one-third as long as metanotum (Figure 7B)

M. chaperi

- Metanotum with sparse pilosity; mid portion of basal area of metapostnotum short, about one half as long as metanotum (Figure 7D, E) 7

7 (6). F6-F11 about as wide as remaining flagellomeres (Figure 8F); basal area of metapostnotum often lacking longitudinal rugulosities, only rarely with a few weak rugulosities in its mid portion (Figure 7C); S3 mostly flat, lacking a mid longitudinal sulcus (Figure 8B); S4 with pilosity basally, its apical margin slightly notched laterally (Figure 9B) ....

M. amoena

- F6-F11 wider than remaining flagellomeres (Figure 9A); basal area of metapostnotum with longitudinal rugulosities in mid portion (Figure 7D, E); S3 with a weakly impressed longitudinal sulcus (Figure 8C); S4 lacking pilosity basally, its apical margin strongly notched laterally (Figure 8C) .. 8

8 (7). Mesoscutum, adjacent to parapsidial line, sparsely punctured ( $\geq 1 \mathrm{pd}$ )

M. guimaraesi

- Mesoscutum, adjacent to parapsidial line, densely punctured $(<1 \mathrm{pd})$

M. mura sp. $\mathrm{n}$.

9 (1). Inner orbit of eye only slightly angled; ocellocular distance longer than F1 length (Figures 9C-F, 10A); F2 about two-thirds of F3 in length; dorsal surface of flagellomeres flat (Figure 10B)... byroni group ... 10

- Inner orbit of eye strongly angled (Figure 10C); ocellocular distance shorter than F1 length; F2 about as long as F3; dorsal surface of flagellomeres strongly depressed (Figure 10D) ..... 

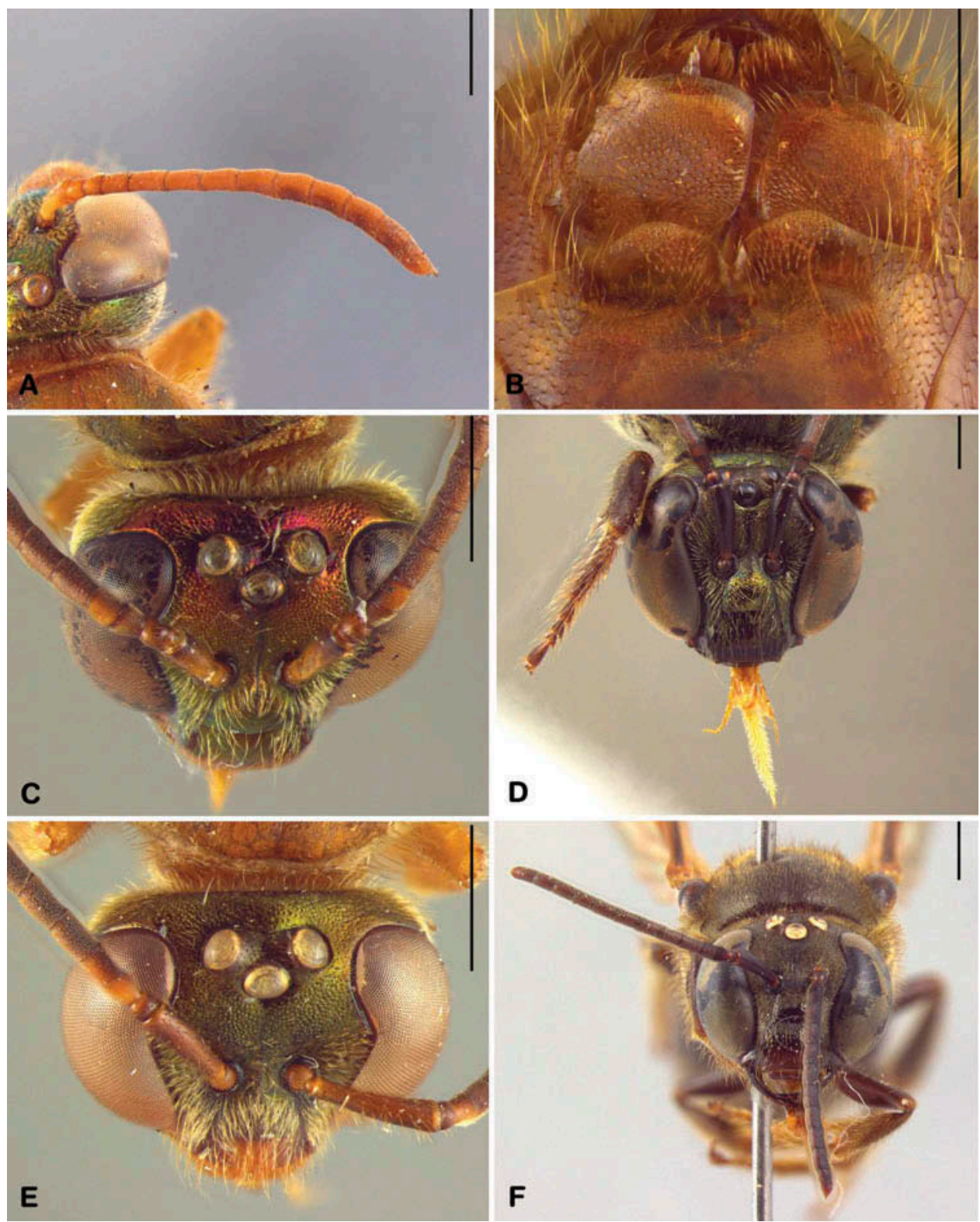

Figure 9. Males of Megalopta. (A) Dorsal view of flagellum of M. guimaraesi from Formosa, Brazil; (B) ventral view of sternum 3-4 of M. amoena from Alenquer, Brazil; (C, E) dorsal view of head; (D, F) Frontal view of head; (C) M. guarani sp. n. from Chapada dos Guimarães, Brazil; (D) M. mapinguari sp. n. from Rio Branco, Brazil; (E) M. xavante sp. n. from Nova Xavantina, Brazil; (F) M. atlantica Santos \& Silveira from Ipanema, Brazil. Scale bar $1 \mathrm{~mm}$. 


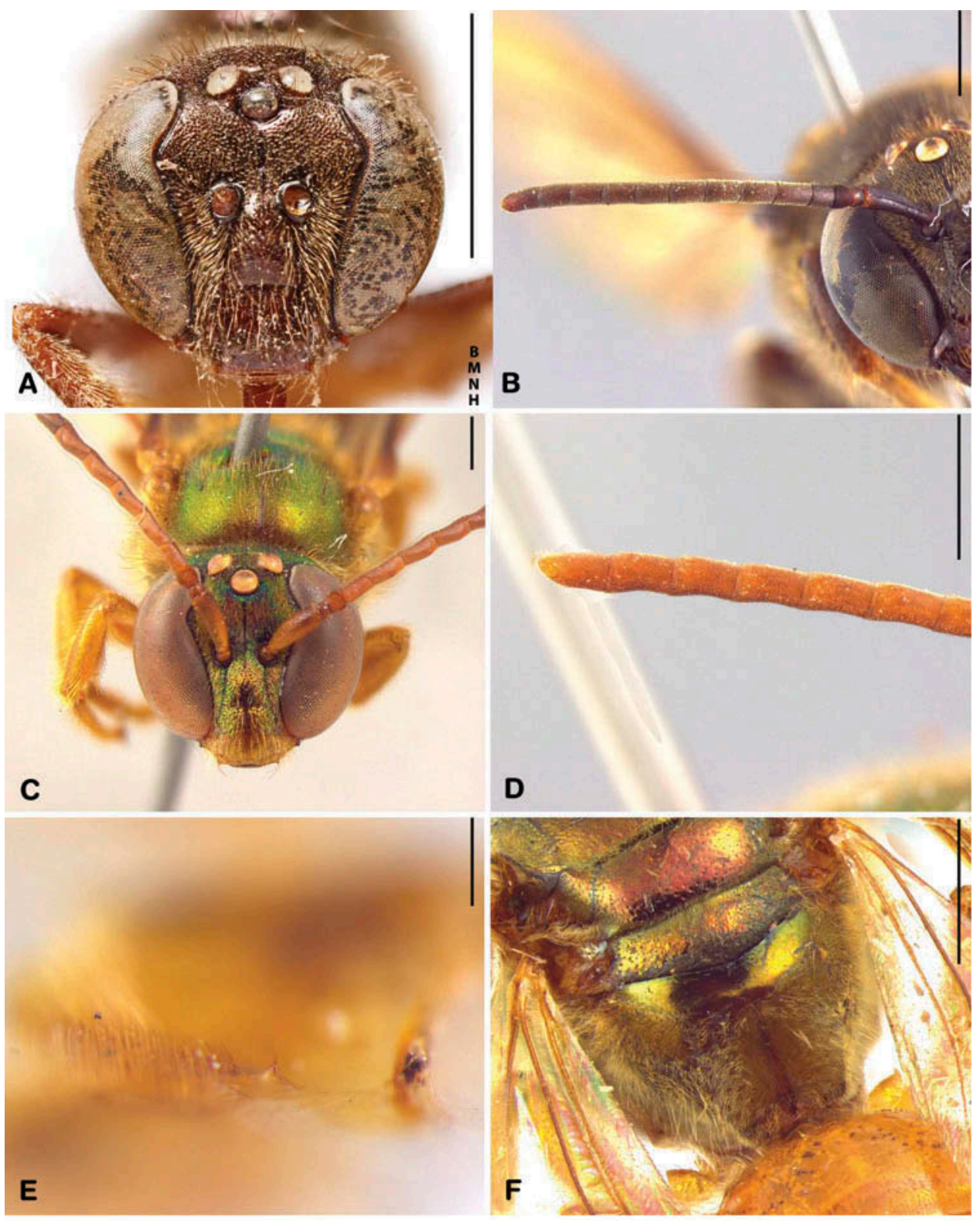

Figure 10. Males of Megalopta. (A, C) Frontal view of head; (B, D) frontal view of flagellomeres; (A) M. purpurata Smith (holotype) from Tefé, Brazil; (B) M. atlantica Santos \& Silveira from Ipanema, Brazil; (C) M. yanomami sp. n. from Parauapebas, Brazil; (D) $M$. piraha sp. n. from Manaus, Brazil; (E) lateral view of sternum 4 of $M$. guarani sp. n. from Chapada dos Guimarães, Brazil; (F) posterolateral view of basal area of mesosoma $M$. guarani sp. n. from Chapada dos Guimarães, Brazil. Scale bar $1 \mathrm{~mm}$, except in E, scale bar $0.1 \mathrm{~mm}$. 
10 (9). Protruding process of S4 short, triangular shaped in lateral view (Figure 10E); basal area of metapostnotum without longitudinal rugulosities 11

- Protruding process of S4 digitiform (Figure 11B); basal area of metapostnotum with longitudinal rugulosities, or if rugulosities absent then the integument mostly dark brown to black (Figures 11C-F) 12

11 (10). Head and mesosoma metallic green with coppery tints, metasoma reddish brown (Figures 9C, 10F) M. guarani sp. n.

- Head and mesosoma dark brown with metallic green reflections, metasoma dark brown with purple tints (Figure 11A) M. karitiana sp. $\mathrm{n}$.

12 (10). Mesosoma homogeneously metallic green (Figure 11C)

M. mapinguari $\mathrm{sp} . \mathrm{n}$.

- Mesosoma dark brown to black with metallic green tints on mesoscutum, scutellum, metanotum and basal area of metapostnotum (Figure 12A-C) 13

13 (12). Integument mostly brown with metallic green tints (Figure 12A)

M. xavante sp. $\mathrm{n}$.

- Integument mostly dark brown to black (Figure 12B, C) 14

14 (13). Basal area of metapostnotum with longitudinal rugulosities longer on mid portion, becoming shorter laterally (Figure 11E)

M. atlantica

- Basal area of metapostnotum smooth, without longitudinal rugulosities (Figure 11F) M. purpurata

15 (9). Mid portion of basal area of metapostnotum flattened, longitudinal rugulosities absent or only a few present (Figure 12D, E) .......................... 16

- Mid portion of basal area of metapostnotum weakly concave, numerous longitudinal rugulosities present (Figures 12F, 13A, B) 17

16(15). Scape uniformly enlarged (Figure 13C); flagellomeres with depressed and glabrous area (Figure 13D); basal area of metapostnotum dark green, longitudinal rugulosities strongly impressed and enclosed laterally by two sulci (Figure 12D) M. yanomami sp. $\mathrm{n}$.

- Scape gradually enlarging toward the apex (Figure 13E); flagellomeres without depressed and glabrous area (Figure 10D); basal area of metapostnotum light green, longitudinal rugulosities not enclosed by two lateral sulci (Figure 12E) M. piraha sp. n.

17 (15). Basal area of metapostnotum with shorter and weakly impressed longitudinal rugulosities (Figure 12F) M. munduruku sp. $\mathrm{n}$.

- Basal area of metapostnotum with longer and strongly impressed longitudinal rugulosities 18

18 (17). Integument mostly dark brown to black (Figure 13A, F)

- Integument mostly metallic green (Figure 13B) 

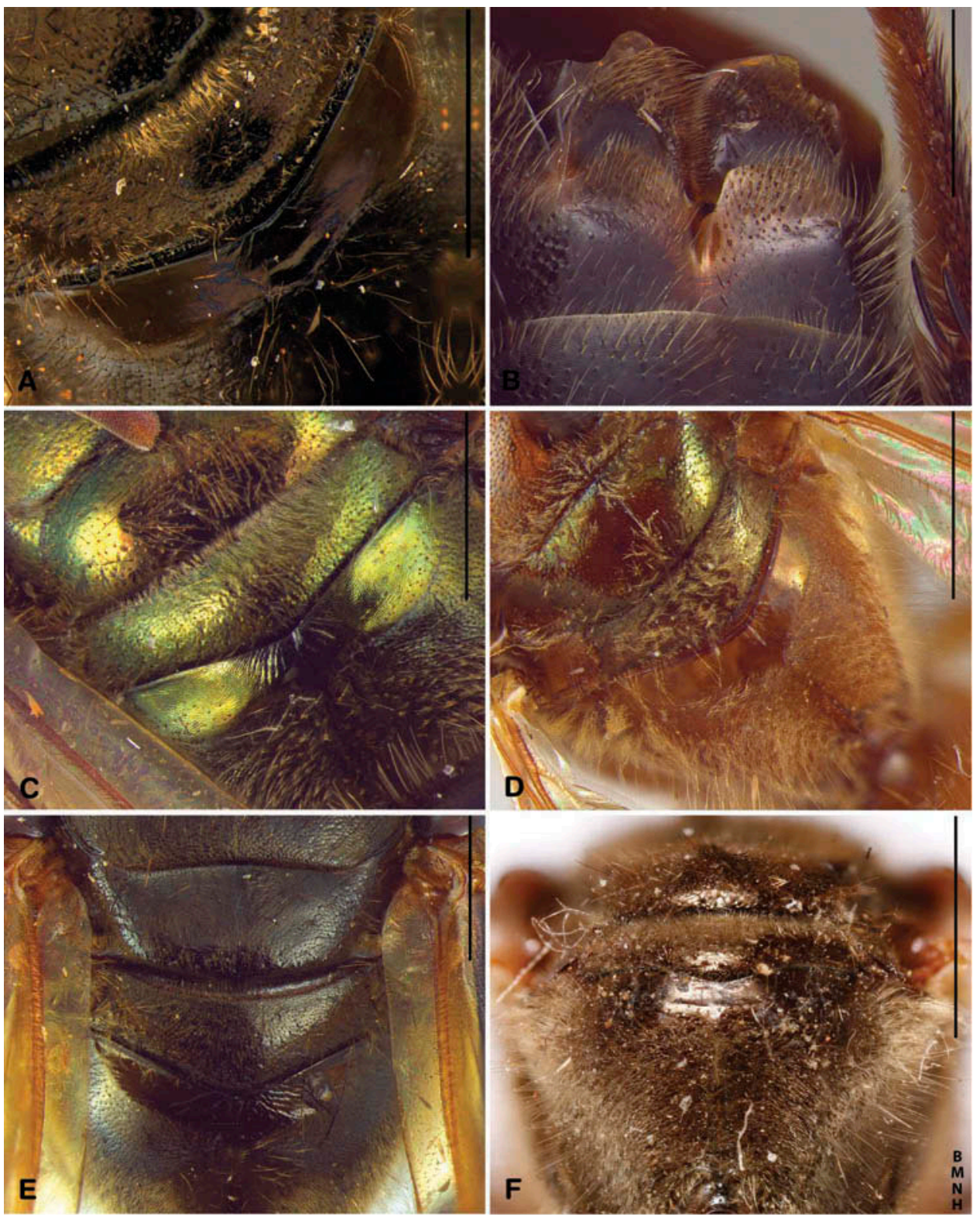

Figure 11. Males of Megalopta. (A, C, D). Posterolateral view of mesosoma; (A) M. karitiana sp. n. from Ouro Preto do Oeste, Brazil; (B) ventral view of sternum 3-4 of $M$. mapinguari sp. n. from Rio Branco, Brazil; (C) M. mapinguari sp. n. from Rio Branco, Brazil; (D) M. xavante sp. n. from Nova Xavantina, Brazil; (E) dorsal view of mesosoma of $M$. atlantica Santos \& Silveira from Ipanema, Brazil; (F) posterior view of mesosoma of $M$. purpurata Smith (holotype) from Tefé, Brazil. Scale bar $1 \mathrm{~mm}$. 

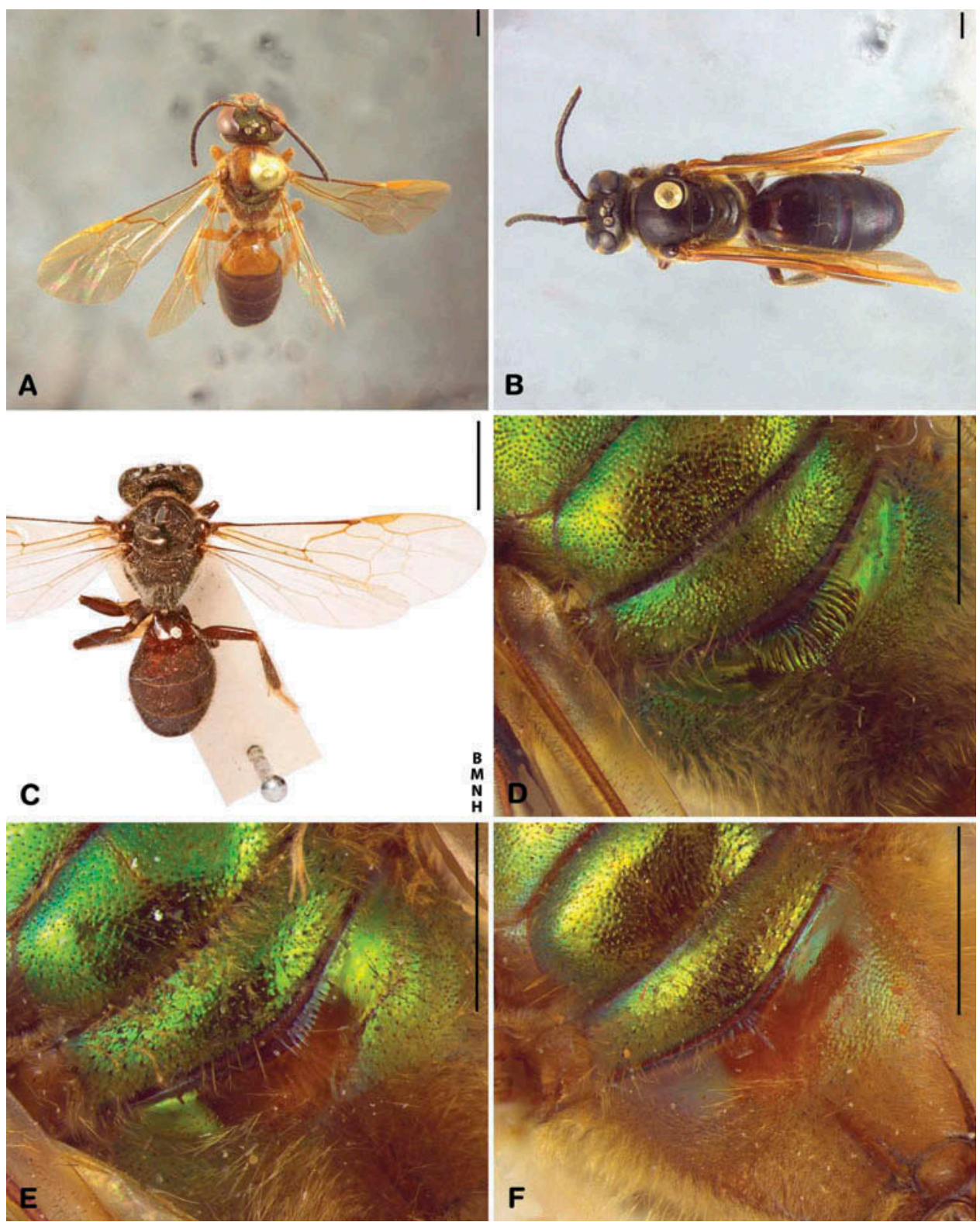

Figure 12. Males of Megalopta. (A-C) Habitus, dorsal view; (A) M. xavante sp. n. from Nova Xavantina, Brazil; (B) M. atlantica Santos \& Silveira from Ipanema, Brazil; (C) M. purpurata (holotype) Smith from Tefé, Brazil; (D-F) posterolateral view of mesosoma; (D) M. yanomami sp. n. from Parauapebas, Brazil; (E) M. piraha sp. n. from Manaus, Brazil; (F) M. munduruku sp. n. from Belterra, Brazil. Scale bar $1 \mathrm{~mm}$. 

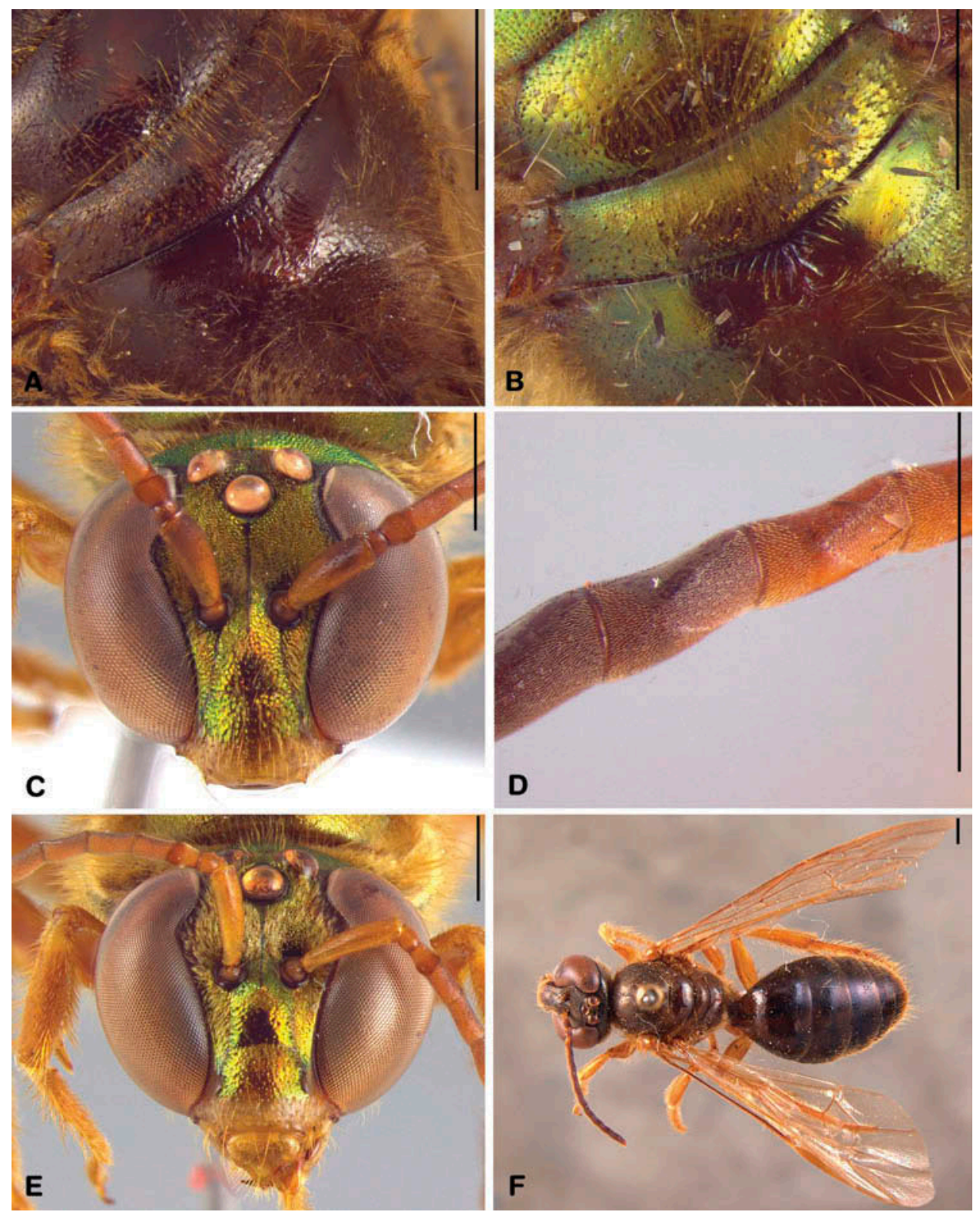

Figure 13. Males of Megalopta. (A, B) Posterolateral view of mesosoma; (C, E) frontal view of head; (D) frontal view of flagellomeres; (A) M. cuprea Friese from Santa Cruz, Bolivia; (B) M. sodalis Vachal from Antonina, Brazil; (C, D) M. yanomami sp. n. from Parauapebas, Brazil; (E) M. piraha sp. n. from Manaus, Brazil; (F) M. cuprea Friese from Espejo, Santa Cruz, Bolivia. Scale bar $1 \mathrm{~mm}$. 


\section{The aegis species group}

\section{Diagnosis}

The aegis species group includes $M$. aegis, $M$. aeneicollis, $M$. nitidicollis and $M$. sulciventris. Its species can be identified by the following characters: posterior margin of basal area of metapostnotum arcuate, gradually curved toward the metanotum laterally, the longitudinal rugulosities sometimes numerous and present laterally (Figure 1D); upper frons conspicuously convex, strongly declivous toward sulcus around median ocellus (Figure 1E); male with glabrous basal portion of F6-F11 expanded (Figure 8D, E); posterior upper margin of metepisternum modified into a conspicuously large process covered with velvety pilosity in both sexes, its diameter at least $0.5 \times$ the tegula length (Figure $1 \mathrm{~A}$ ); basal area of metapostnotum laterally with rugulose surface, the posterior margin arcuate, gradually curved towards the anterior margin laterally (Figure 1D, 2B-D, 6C-6F); 1st and 2nd tarsomere of foreleg with longest simple setae longer than summed length of the three apical tarsomeres and $\mathrm{T} 1$ with contiguous punctation.

Megalopta aeneicollis, M. nitidicollis and M. sulciventris inhabit the Amazon Basin (Figure 14A-C), while M. aegis occurs in the savannahs of central Brazil (cerrado) and in the Atlantic Forest of eastern Brazil (Figure 14A).

Megalopta aegis (Vachal 1904)

(Figures 1E, 2D, 6E, 7A, 8E, 14A)

Halictus aegis Vachal, 1904: 115. Lectotype male, Brazil: Goiás, Jataí (MNHP, not examined).

Examined material

(374우, 49ð). See Appendix 2.

\section{Diagnosis}

The female differs from that of $M$. nitidicollis by the weak longitudinal rugulosities along its entire surface of the basal area of metapostnotum; from $M$. aeneicollis by reddish brown basal area of metapostnotum and by the imbricated rugulosities in its lateral surface (Figure 2D); from $M$. sulciventris by metanotum with dense short plumose pilosity present on its entire surface and by colour of integument of basal area of metapostnotum, entirely reddish brown or reddish brown in the centre with green tints laterally (Figure 2D). The male differs from that of $M$. sulciventris by the F6-F11 basally with glabrous area levelled to remainder of flagellomere surface (Figure $8 \mathrm{E}$ ), metanotum with very dense pilosity covering entire disc, obscuring the integument in dorsal view, and by reddish brown basal area of metapostnotum; from $M$. aeneicollis and $M$. nitidicollis by basal area of metapostnotum with strongly impressed longitudinal rugulosities along its entire surface (Figure 6E). 

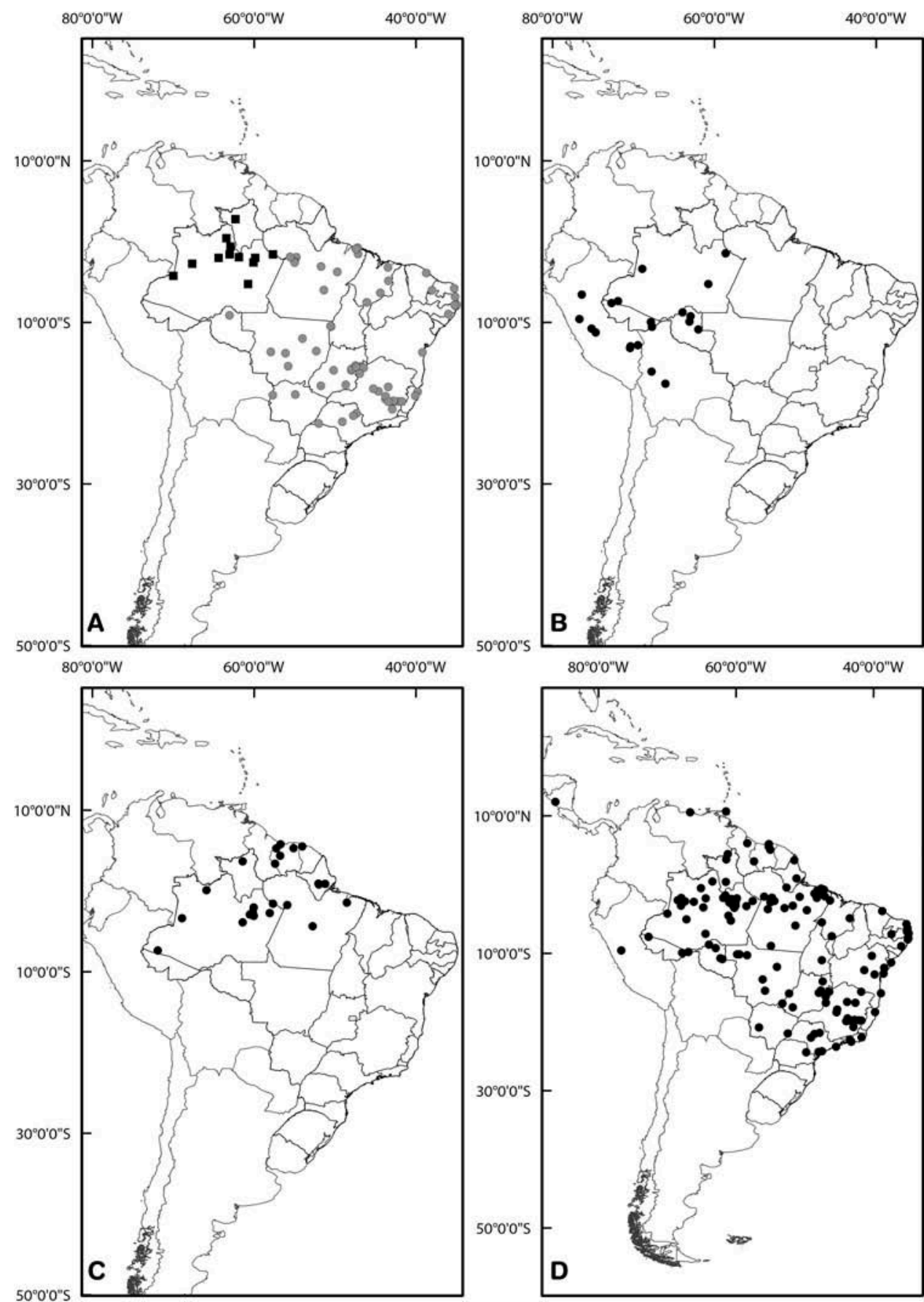

Figure 14. Distribution records of Megalopta species. (A) M. aegis Vachal (grey circles) and M. aeneicollis Friese (black squares); (B) M. nitidicollis Friese; (C) M. sulciventris Friese; (D) M. amoena Spinola. 


\section{Description}

Female. (1) Mandible bidentate and with supplementary teeth. (2) Labral elevation with lateral surface slightly raised in relation to central portion. (3) Clypeus* with the surface between punctures on basal and central area variable, microreticulate in most specimens or smooth in a few ones. (4) Central portion of supraclypeal area with sparse punctation, punctures separated by $\geq 1 \mathrm{pd}$. (5) Antenna reddish brown. (6) Upper frons conspicuously convex, strongly declivous toward sulcus around median ocellus (Figure 1E). (7) Ocellocular distance smaller than the F1 length. (8) Mesoscutum adjacent to parapsidial line densely punctured, punctures contiguous, punctation becoming sparser towards mesoscutal lip $(<1 \mathrm{pd})$. (9) Scutellum with posterior margin raised in relation to anterior margin of metanotum. (10) Metanotum with integument, in oblique view, hidden by dense short plumose pilosity. (11) Basal area of metapostnotum* reddish brown; its length half of that of metanotum; with longer longitudinal rugulosities medially, rugulosities shorter and weakly impressed laterally, surface between longitudinal rugulosities punctured (Figure 2D) or with longitudinal rugulosities weakly impressed throughout, strongly impressed rugulosities restricted to lateral areas and along apical margin. (12) Mesepisternum with contiguous punctation. (13) Metepisternum with sparse pilosity, integument visible through pilosity, posterior upper margin of modified into a conspicuously large process covered with velvety pilosity, its diameter at least $0.5 \times$ tegula length. (14) T1 with dorsal surface of disc densely punctured $(<1 \mathrm{pd})$, posterior marginal zone smooth between punctures. Male. (15) Scape with diameter gradually enlarging toward the apex. (16) Flagellum reddish brown, F1-F11 not differing in diameter; F2 about as long as F3; F6-F11, in anterior view, with the anterior and posterior margins depressed, in posterior view with basal glabrous area at same level of remaining surface (Figure 8E). (17) Metanotum with integument, in dorsal view, hidden by dense short plumose pilosity (Figure 6E). (18) Basal area of metapostnotum reddish brown, sometimes with green highlights laterally; its length half of that of metanotum; with longer longitudinal rugulosities medially, rugulosities shorter and weakly impressed laterally (Figure 6E). (19). Metepisternum as in female. (20) 1 st and 2 nd tarsomeres of foreleg with longest simple setae longer than summed length of the three apical tarsomeres. (21) S3 with longitudinal sulcus, posterolateral margin notched (Figure 7A). (22) S4 with medial protruding process, profile of process triangular in lateral view; basal portion glabrous; posterolateral margin notched, notch not extending to basal half of sclerite (Figure 7A).

\section{Measurements}

Approximate body length: (10.5-15.0); maximum width of head: (2.9-4.8); intertegular distance: (3.0-4.2); forewing length with the tegula: (9.4-11.8).

\section{Comments}

Some specimens of $M$. aegis from eastern Brazil have smooth interspaces between punctures in the basal and central area of the clypeal disc and weakly impressed 
rugulosities in the basal area of the metapostnotum. This variation, however, is not consistently present in all specimens and the recognition of a separate species from eastern Brazil seems unwarranted.

\section{Distribution}

BRAZIL. Alagoas: Ibateguara. Bahia: Ituberá. Ceará: Maranguape. Distrito Federal. Espírito Santo: Conceição da Barra, Linhares. Goiás: Alto Paraíso de Goiás, Caldas Novas, Formosa, Goiás, Jataí, Planaltina. Maranhão: Balsas, Caxias, Mirador, Urbano Santos. Mato Grosso: Campo Novo dos Parecis, Canabrava do Norte, Canarana, Chapada dos Guimarães, Nova Mutum, Santa Terezinha. Mato Grosso do Sul:

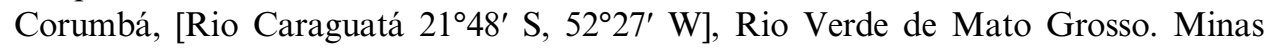
Gerais: Buritis, Caratinga, Dionísio, Ipanema, Jaboticatubas, Marliéria, Morro da Garça, São Gonçalo do Rio Abaixo, São Gonçalo do Rio Preto, Santana do Riacho, Três Marias, Unaí, Viçosa. Pará: Alenquer, Altamira, Belém, Belterra, Bragança, Bujaru, Capitão Poço, Óbidos, Ourém, Parauapebas, Santarém, Santarém Novo, São João de Pirabas, Tome Açu, Tucuruí. Paraíba: Mamanguape. Pernambuco: Igarassu, Paudalho, São Lourenço da Mata. Rio Grande do Norte: Portalegre, Natal. Rondônia: Itapuã do Oeste. São Paulo: Bauru, Cajuru, Luís Antônio, São Carlos. Tocantins: Formoso do Araguaia (Figure 14A).

Megalopta aeneicollis Friese, 1926

(Figures 1A, 2C, 6A, 6D, 14A)

Megalopta aeineicollis Friese, 1926:132. Lectotype female, Brazil: Amazonas, Barcelos (ZMB, examined).

Additional examined material

(38ㅇ, 5ठ). See Appendix 2.

\section{Diagnosis}

The female differs from that of $M$. nitidicollis by the evenly strongly impressed longitudinal rugulosities along entire surface of the basal area of metapostnotum (Figure 2C); from M. aegis and M. sulciventris by the basal area of metapostnotum often orangish, entirely finely rugulose, stronger rugulosities rectilinear and long along entire surface (Figure 2C). The male is distinguished from that of M. sulciventris by the F6-F11 basally with glabrous area levelled to remainder of flagellomere surface, metanotum with very dense pilosity covering entire disc, obscuring the integument in dorsal view, and by basal area of metapostnotum light orangish brown (Figure 6D); from M. aegis and M. sulciventris by the basal area of metapostnotum entirely finely rugulose, and with its posterior margin slightly raised (Figure 6D). 


\section{Description}

Female. (1) Mandible bidentate and with supplementary teeth. (2) Labral elevation with lateral surface slightly raised in relation to central portion. (3) Clypeus with the surface between punctures on basal and central area smooth. (4) Central portion of supraclypeal area with sparse punctation, punctures separated by $\geq 1 \mathrm{pd}$. (5) Antennae reddish brown. (6) Upper frons conspicuously convex, strongly declivous toward sulcus around median ocellus. (7) Ocellocular distance smaller than the F1 length. (8) Mesoscutum adjacent to parapsidial line densely punctured, punctures contiguous, punctation becoming sparser towards mesoscutal lip $(<1 \mathrm{pd})$. (9) Scutellum with posterior margin raised in relation to anterior margin of metanotum. (10) Metanotum with integument, in oblique view, hidden by dense short plumose pilosity (Figure 2C). (11) Basal area of metapostnotum orangish, without metallic reflections, its length at least $0.8 \times$ that of metanotum; surface entirely finely rugulose, stronger rugulosities rectilinear and long along entire surface (Figure 2C). (12) Mesepisternum with contiguous punctation. (13) Metepisternum with sparse pilosity, integument visible through pilosity, posterior upper margin modified into a conspicuously large process covered with velvety pilosity, its diameter at least $0.5 \times$ tegula length (Figure 1A). (14) T1 with dorsal surface of disc densely punctured $(<1 \mathrm{pd})$, posterior marginal zone smooth between punctures. Male. (15) Scape with diameter gradually enlarging toward the apex. (16) Flagellum reddish brown, F1-F11 not differing in diameter; F2 about as long as F3; F6-F11, in anterior view, with the anterior and posterior margins depressed, in posterior view with basal glabrous area at same level of remaining surface. (17) Metanotum with integument, in dorsal view, hidden by dense short plumose pilosity (Figure 6D). (18) Basal area of metapostnotum orangish, its length half of that of metanotum, medially with longer longitudinal rugulosities, laterally with microreticulated surface (Figure 6D). (19) Metepisternum as in the female. (20) 1 st and 2nd tarsomeres of foreleg with longest simple setae longer than summed length of the three apical tarsomeres. (21) S3 with longitudinal sulcus, posterolateral margin notched. (22) S4 with medial protruding process, profile of process triangular in lateral view; basal portion glabrous; posterolateral margin notched, notch not extending to basal half of sclerite.

\section{Measurements}

Approximate body length: (12.9-14.0); maximum width of head: (3.5-4.3); intertegular distance: (3.6-4.3); forewing length with the tegula: (10.9-11.8).

\section{Distribution}

BRAZIL. Amazonas: Barcelos, Japurá, Manaus, Novo Airão, Novo Aripuanã, Presidente Figueiredo, Tabatinga. Roraima: Mucajaí (Figure 14A).

Megalopta nitidicollis Friese, 1926

(Figures 2B, 6F, 14B)

Megalopta nitidicollis Friese, 1926: 130. Lectotype female, presently designated, Bolivia: Cochabamba, Tarata (ZMB, examined). 


\section{Type material}

There is one female and one male syntype in the ZMB collection. The female, with the labels 'Bolivia\ Tarata\1900', 'Megalopta\ nitidicollis $\$ 910$ Friese det.', 'Coll.I Friese' 'LECTOTYPE\Megalopta\ nitidicollis $\backslash$ † Friese, 1926\desig. Melo 2010', is here designated lectotype.

\section{Additional examined material}

(31 q, 27 §). See Appendix 2.

\section{Diagnosis}

The female differs from those of $M$. aegis, M. aeneicollis and M. sulciventris by the weakly impressed longitudinal rugulosities in the central portion of the basal area of metapostnotum, in contrast with the strong rugulosities laterally, and by the integument of the basal area often reddish brown on basal half and metallic green on apical half (Figure 2B). The male is distinguished from that of $M$. sulciventris by glabrous basal portion of F6-F11 levelled to remainder of flagellomere surface; metanotum with very dense pilosity covering entire disc, obscuring the integument in dorsal view, and by the basal area of metapostnotum reddish brown on basal half and metallic green apically (Figure 6F); from M. aeneicollis by basal area of metapostnotum in posterior margin forming a carina; from $M$. aegis by basal area of metapostnotum lacking longitudinal rugulosities or only with a few weak rugulosities in its mid portion (Figure 6F).

\section{Description}

Female. Mandible bidentate and with supplementary teeth. (2) Labral elevation with lateral surface slightly raised in relation to central portion. (3) Clypeus. Surface between punctures on basal and central area smooth. (4) Central portion of supraclypeal area with sparse punctation, punctures separated by $\geq 1$ pd. (5) Antennae reddish brown. (6) Upper frons conspicuously convex, strongly declivous toward sulcus around median ocellus. (7) Ocellocular distance smaller than the F1 length. (8) Mesoscutum adjacent to parapsidial line densely punctured, punctures contiguous, punctation becoming sparser towards mesoscutal lip ( $<1 \mathrm{pd}$ ). (9) Scutellum with posterior margin raised in relation to anterior margin of metanotum. (10) Metanotum with integument, in oblique view, hidden by dense short plumose pilosity (Figure 2B). (11) Basal area of metapostnotum reddish brown in basal half and metallic green in apical half; its length at least $0.6 \times$ that of metanotum; longitudinal rugulosities absent or slightly impressed in central area and weakly impressed laterally (Figure 2B). (12) Mesepisternum with contiguous punctation. (13) Metepisternum with sparse pilosity, integument visible through pilosity, posterior upper margin modified into a conspicuously large process covered with velvety pilosity, its diameter at least $0.5 \times$ tegula length. (14) T1 with dorsal surface of disc densely punctured $(<1 \mathrm{pd})$, posterior marginal zone smooth between punctures. Male. (15) Scape with diameter gradually enlarging toward the apex. (16) Flagellum reddish brown; F1-F11 not differing in 
diameter; F2 about as long as F3; F6-F11, in anterior view, with the anterior and posterior margins depressed, in posterior view with basal glabrous area at same level of remaining surface. (17) Metanotum with integument, in dorsal view, hidden by dense short plumose pilosity (Figure 6F). (18) Basal area of metapostnotum reddish brown, except for the metallic green apex, its length half of that of metanotum, the longitudinal rugulosities limited to sides (Figure 6F). (19) Metepisternum as in the female. (20) 1st and 2nd tarsomeres of foreleg with longest simple setae longer than summed length of the three apical tarsomeres. (21) S3 with longitudinal sulcus, posterolateral margin notched. (22) S4 with medial protruding process, profile of process triangular in lateral view; basal portion glabrous; posterolateral margin notched, notch not extending to basal half of sclerite.

\section{Measurements}

Approximate body length: (10.5-14.6); maximum width of head: (3.3-3.9); intertegular distance: $(3.4-4.1)$; forewing length with the tegula: $(10.1-11.5)$.

\section{Distribution}

BOLIVIA. Cochabamba: Tarata. La Paz: Nigrillani. BRAZIL. Acre: Capixaba, Cruzeiro do Sul, Rio Branco. Amazonas: Ipixuna, Novo Aripuanã, São Paulo de Olivença, Urucará. Rondônia: Ariquemes, Ji-Paraná, Itapuã do Oeste, Porto Velho. PERU. Junin: Satipo. Loreto: Maynas. Madre de Dios: Mazuko, Santa Rosa, Tambopata. San Martin: Juan Guerra (Figure 14B).

\section{Megalopta sulciventris Friese, 1926}

(Figures 1D, 6C, 8D, 14C)

Megalopta sulciventris Friese, 1926:129. Lectotype male, French Guiana: Nouveau Chantier, Bas Maroni (ZMB, examined).

Additional examined material

(93, 14仓). See Appendix 2.

\section{Diagnosis}

The female differs from that of $M$. nitidicollis by the weakly impressed longitudinal rugulosities along entire basal area of metapostnotum (Figure 1D); from M. aeneicollis by the metallic green basal area of metapostnotum and by its imbricated longitudinal rugulosities towards lateral portions (Figure 1D); from M. aegis by the metanotum sometimes with pilosity short and plumose, present only on two-thirds of disc, not obscuring the integument in oblique view (Figure 1D) and basal area of metapostnotum metallic green and with strongly imbricated longitudinal rugulosities (Figure 1D). The male differ from those of M. aegis, M. aeneicollis and M. nitidicollis by the glabrous basal portion of F6-F11 raised in relation to remainder of 
flagellomere surface (Figure 8D); metanotum pilosity present only in two-thirds of disc and not obscuring the integument in dorsal view (Figure 6C); basal area of metapostnotum entirely metallic green or sometimes reddish brown medially (Figure 6C).

\section{Description}

Female. (1) Mandible bidentate and with supplementary teeth. (2) Labral elevation with lateral surface slightly raised in relation to central portion. (3) Clypeus with the surface between punctures on basal and central area smooth. (4) Central portion of supraclypeal area with sparse punctation, punctures separated by $\geq 1 \mathrm{pd}$. (5) Antennae reddish brown. (6) Upper frons conspicuously convex, strongly declivous toward sulcus around median ocellus. (7) Ocellocular distance smaller than the F1 length. (8) Mesoscutum adjacent to parapsidial line densely punctured, punctures contiguous, punctation becoming sparser towards mesoscutal lip (< 1 pd). (9) Scutellum with posterior margin raised in relation to anterior margin of metanotum. (10) Metanotum with integument, in oblique view, hidden by short plumose pilosity only in two-thirds of disc (Figure 1D). (11) Basal area of metapostnotum sometimes metallic green; its length at least $0.7 \times$ that of metanotum; with imbricated longitudinal rugulosities weakly impressed (Figure 1D). (12) Mesepisternum with contiguous punctation. (13) Metepisternum with sparse pilosity, integument visible through pilosity, posterior upper margin modified into a conspicuously large process covered with velvety pilosity, its diameter at least $0.5 \times$ tegula length. (14) $\mathrm{T} 1$ with dorsal surface of disc densely punctured $(<1 \mathrm{pd})$, posterior marginal zone smooth between punctures. Male. (15) Scape with diameter gradually enlarging toward the apex. (16) Flagellum reddish brown; F1-F11 not differing in diameter; F2 about as long as F3; F6-F11, in anterior view, with the anterior and posterior margins depressed; in posterior view with basal glabrous area elevated in relation to remaining surface (Figure 8D). (17) Metanotum with integument, in dorsal view, not hidden by short plumose pilosity (Figure 6C). (18) Basal area of metapostnotum variable, reddish brown with green metallic tints or entirely metallic green; its length half of that of metanotum; with longer longitudinal rugulosities medially, rugulosities shorter laterally (Figure 6C). (19) Metepisternum as in the female. (20) 1st and 2nd tarsomeres of foreleg with longest simple setae longer than summed length of three apical tarsomeres. (21) S3 with longitudinal sulcus, posterolateral margin notched. (22) S4 with medial protruding process, profile of process triangular in lateral view; basal portion glabrous; posterolateral margin notched, notch not extending to basal half of sclerite.

\section{Measurements}

Approximate body length: (10.2-14.3); maximum width of head: (3.4-4.4); intertegular distance: (3.5-4.2); length of forewing with the tegula: (10.8-11.8).

\section{Distribution}

BRAZIL. Amapá: Pedra Branca do Amapari, Ferreira Gomes, Serra do Navio. Amazonas: Barcelos, Beruri, Ipixuna, Manaus, Presidente Figueiredo. Pará: Altamira, Belém, Oriximiná. Roraima: Amajari. FRENCH GUIANA. Saint- 
Laurent-du-Maroni: Saint-Laurent-du-Maroni. SURINAME. Brokopondo: Sarakreek. Nickeri: Wageningen. Sipaliwini: Coeroeni, Coppename, Kabalebo, Sarakreek (Figure 14C).

\section{The amoena species group}

\section{Diagnosis}

The amoena species group includes $M$. amoena, M. chaperi, M. guimaraesi and $M$. mura sp. n. Its species can be recognized by the following characters: posterior upper margin of metepisternum modified into a conspicuously large process covered with velvety pilosity, its diameter at least $0.75 \times$ the tegula length (except in the female of $M$. amoena); male E3 centrally in the apex with sinuous notch adjacent to expanded area of sternum (Figure $8 \mathrm{~A}-\mathrm{C}$ ).

M. amoena is widely distributed (Figure 14D), M. chaperi is restricted to north of the Amazonas and Negro rivers (Figure 15A), M. guimaraesi to the Atlantic Forest and Cerrado and M. mura sp. n. to north-western South America (Figure 15B).

Megalopta amoena (Spinola 1853)

(Figures 2F, 5D, 7C, 8B, 8F, 9B, 14D)

Halictus amoenus Spinola, 1853: 85. Holotype male, Brazil: Pará (MSNT, examined through photographs).

Megalopta idalia Smith, 1853: 84. Syntypes, Brazil: Amazonas and Pará, Santarém (BMNH, not examined).

Halictus argoides Vachal, 1904:115. Holotype male, Guyana (MNHP, not examined).

Megalopta ochrias Vachal, 1904:115. Holotype male, Brazil: Goiás, Jataí (MNHP, not examined).

Megalopta ecuadoria Friese, 1926: 127. Lectotype female, Ecuador: Guayas, Guayaquil (ZMB, examined).

Megalopta centralis Friese, 1926: 128. Lectotype male, Guatemala (ZMB, examined).

Megalopta gibbosa Friese, 1926:128. Holotype male, Ecuador: Guayas, Guayaquil, (ZMB, examined). New synonymy.

Megalopta lecointei Friese, 1926:122. Lectotype female, presently designated, Brazil: Pará, Óbidos (ZMB, examined). New synonymy.

Megalopta vigilans Cockerell, 1923:1. Holotype male, uncertain type locality (AMNH, examined through photographs). New synonymy.

\section{Type material examined}

In addition to the type material listed above, we also examined one female and one male syntypes of Megalopta lecointei in the ZMB collection. The female, with the labels 'Obidos\1904\P. Lecointe', 'Brazil\ Estado\ Pará', 'Megalopta O \lecointei Duckel n.sp.', 'Megalopta\ lecointei Duckel n.sp.', 'Coll. \ Friese' 'Zool. Mus.। Berlin', 'Type', is here designated lectotype. The male paralectotype bears the labels

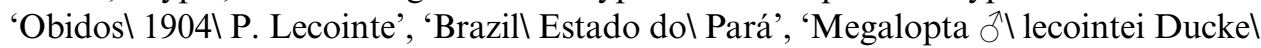
n.sp.', 'Coll. \Friese', 'Megalopta\ lecointei\ H. Friese 19 Ducke' 'Typus'. 

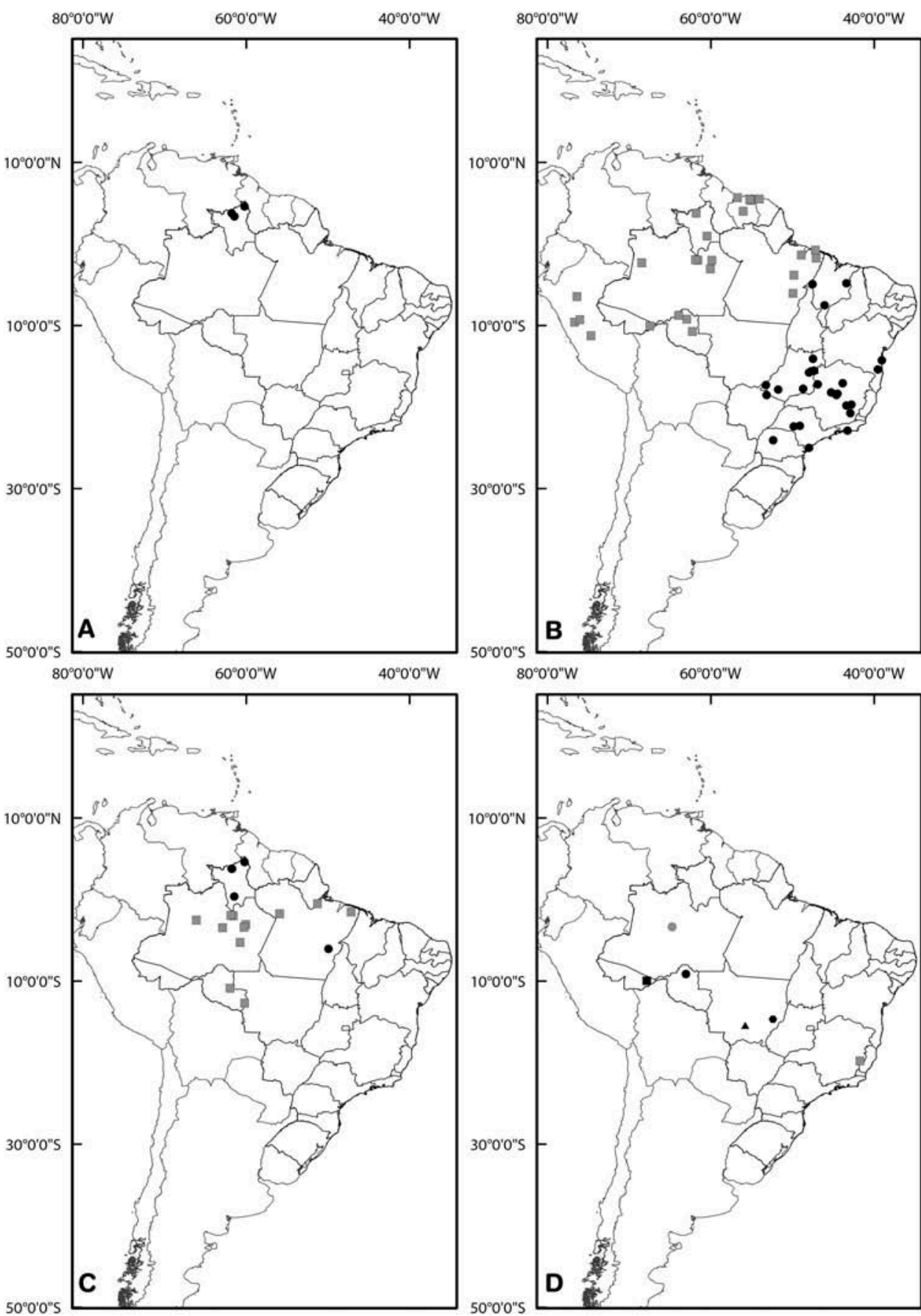

Figure 15. Distribution records of Megalopta species. (A) M. chaperi Vachal; (B) M. guimaraesi Santos \& Silveira (black circles) and M. mura sp. n. (grey squares); (C) M. piraha sp. n (grey squares) and M. yanomami sp. n. (black circles); (D) M. atlantica Santos \& Silveira (grey square), M. guarani sp. n (triangle), M. xavante sp. n (hexagon), M. karitiana sp. n (black circle), M. mapinguari sp. n (black square) and M. purpurata Smith (grey circle). 
Additional examined material

(833ㅇ, 155ð⿱). See Appendix 2.

\section{Diagnosis}

The female differs from those of $M$. chaperi, M. guimaraesi and M. mura sp. n. by posterior upper margin of metepisternum unmodified, lacking a velvety process (Figure 5D) and by the smooth basal area of metapostnotum lacking rugulosities (Figure $2 \mathrm{~F}$ ). The male is distinguished from that of $M$. chaperi by the metanotum in dorsal view with sparse pilosity and by the short basal area of metapostnotum, its length at least $0.8 \times$ that of metanotum (Figure 7C); from $M$. guimaraesi and $M$. mura sp. n. by F6-F11 about as wide as basal flagellomeres (Figure 8F), central area of basal area of metapostnotum without longitudinal rugulosities (Figure 7C), S3 without longitudinal carina (Figure 8B) and S4 basally with pilosity, its apical margin slightly notched laterally (Figure 9B).

\section{Description}

(1) Mandible bidentate and with supplementary teeth. (2) Labral elevation sometimes with flattened surface. (3) Clypeus with surface between punctures on basal and central area smooth. (4) Central portion of supraclypeal with dense punctation, punctures separated by $<1$ pd. (5) Antennae reddish brown. (6) Upper frons flat, not strongly declivous toward sulcus around median ocellus. (7) Ocellocular distance smaller than the F1 length. (8) Mesoscutum adjacent to parapsidial line densely punctured, punctures contiguous, punctation becoming sparser towards mesoscutal lip ( $<1 \mathrm{pd})$. (9) Scutellum with posterior margin raised in relation to anterior margin of metanotum. (10) Metanotum with integument, in oblique view, not hidden by short plumose pilosity. (11) Basal area of metapostnotum often reddish brown (sometimes metallic green), its length $0.8-1 \times$ that of metanotum, often lacking longitudinal rugulosities (Figure 2F), but rarely with weak grooves. (12) Mesepisternum with contiguous punctation. (13) Metepisternum often with dense pilosity, integument not visible through pilosity, posterior upper margin unmodified, lacking a velvety process (Figure 5D). (14) T1 with dorsal surface of disc sparsely punctured ( $\geq 1 \mathrm{pd}$ ), posterior marginal zone smooth between punctures. Male. (15) Scape with diameter gradually enlarging toward the apex. (16) Flagellum reddish brown, F1-F11 not differing in diameter (Figure 8F); F2 about as long as F3; F6-F11, in anterior view with the anterior and posterior margins depressed, in posterior view with basal portion levelled with remaining surface. (17) Metanotum in dorsal view, not hidden by short plumose pilosity (Figure 7C). (18) Basal area of metapostnotum as in the female (Figure 7C). (19) Metepisternum with dense pilosity, integument not visible through pilosity, posterior upper margin modified into a conspicuously large process covered with velvety pilosity, its diameter at least $0.75 \times$ the tegula length. (20) 1 st and 2nd tarsomeres of foreleg with longest simple setae shorter than the summed length of the three apical tarsomeres. (21) S3 with longitudinal sulcus absent, the central and apical margin sinuous and posterolateral margin sinuous, not notched (Figure 8B). (22) S4 with medial protruding process, profile of process triangular in 
lateral view; basal portion with dense short pilosity; posterolateral margin sinuous, the apical margin without a set of dense hairs (Figure 9B).

\section{Measurements}

Approximate body length: (9.2-12.9); maximum width of head: (2.7-3.6); intertegular distance: (2.7-4.3); length of forewing with the tegula: (8.2-10.4).

\section{Comments}

Several females exhibit metallic green highlights in the mesoscutum and some males have a metallic green basal area of the metapostnotum.

\section{Distribution}

BRAZIL. Acre: Acrelândia, Cruzeiro do Sul, Rio Branco. Alagoas: Ibateguara. Amapá: Ferreira Gomes, Oiapoque. Amazonas: Caruari, Japurá, Fonte Boa, Itacoatiara, Lábrea, Manaquiri, Manaus, Marãa, Novo Airão, Novo Aripuanã, Presidente Figueiredo, Santo Antônio do Iça, Tabatinga, Tefé. Bahia: Alagoinhas, Belmonte, Brejões, Lençois, Salvador, Senhor do Bonfim. Ceará: Maranguape. Distrito Federal. Espírito Santo: Conceição da Barra. Goiás: Alto Paraíso de Goiás, Jataí, Planaltina. Maranhão: Balsas, Caxias, Imperatriz. Mato Grosso: Alto Araguaia, Aripuanã, Barra dos Garças, Chapada dos Guimarães, Canarana, Juruena, Nova Mutum. Mato Grosso do Sul: Bataguaçu, Bonito. Minas Gerais: Belo Horizonte, Berizal, Bocaiúva, Buritis, Caratinga, Dionísio, Ipanema, Jaboticatubas, Marliéria, Minas Novas, Morada Nova de Minas, Paracatu, São Gonçalo do Rio Abaixo, Três Marias, Unaí, Viçosa. Pará: Acará, Alenquer, Altamira, Aveiro, Belterra, Bujaru, Capitão Poço, Maracanã, Medicilândia, Melgaço, Monte Alegre, Oriximiná, Santarém, São João de Pirabas, Tucuruí, Vigia. Paraíba: João Pessoa, Mamanguape, Maturéia. Pernanbuco: Camaragibe, Igarassu. Rio de Janeiro: Macaé, Nova Iguaçu, Rio de Janeiro. Rio Grande do Norte: Baia Formosa, Natal. Rondônia: Itapuã do Oeste, Ji-Paraná, Ouro Preto do Oeste, Porto Velho. Roraima: Amajari, Pacaraima. São Paulo: Alvinlândia, Bauru, Caraguatatuba, Luís Antônio, Miracatu, Nova Europa, Sete Barras. Sergipe: Santa Luzia do Itanhy. Tocantins: Pindorama do Tocantis. ECUADOR. Guayas: Guayaquil. GUATEMALA. GUYANA. Upper Demerara-Berbice: Linden. NICARAGUA. Masaya: Ticuantepe. PANAMA. PERU. Loreto: Maynas. SURINAME. Brokopondo: Brokopondo. Para: Zuid. Paramaribo: Paramaribo. Sipaliwini: Coeroeni, unknown locality. TRINIDAD AND TOBAGO: Tunapuna/ Piarco: Curepe. VENEZUELA: Miranda: Curupao (Figure 14D).

Megalopta chaperi (Vachal, 1904)

(Figures 2E, 7B, 8A, 15A)

Halictus chaperi Vachal, 1904:113. Holotype female, Venezuela (MNHP, not examined). 


\section{Examined material}

$(8+, 2 \precsim)$. See Appendix 2.

\section{Diagnosis}

This species differs from $M$. amoena, M. guimaraesi and $M$. mura sp. n. by the very short basal area of metapostnotum, its length about one-third as long as metanotum (Figure 2E). Its males are also distinguished by the metanotum in dorsal view with dense pilosity (Figure 7B).

\section{Description}

Female. (1) Mandible bidentate and with supplementary teeth. (2) Labral elevation with lateral surface slightly raised in relation to central portion. (3) Clypeus with the surface between punctures on basal and central area variable, microreticulate or sometimes smooth. (4) Central portion of supraclypeal area with sparse punctation, punctures separated by $\geq 1 \mathrm{pd}$. (5) Antennae reddish brown. (6) Upper frons flat, not strongly declivous toward sulcus around median ocellus. (7) Ocellocular distance smaller than the F1 length. (8) Mesoscutum adjacent to parapsidial line densely punctured, punctures contiguous, punctation becoming sparser towards mesoscutal lip (<1 pd). (9) Scutellum with posterior margin raised to anterior margin of metanotum. (10) Metanotum with integument, in oblique view, not hidden by short plumose pilosity. (11) Basal area of metapostnotum reddish brown, about one-third as long as metanotum, with few longitudinal rugulosities restricted to central area, laterally smooth along basal half and microreticulated along apical region (Figure 2E). (12) Mesepisternum with contiguous punctation. (13) Metepisternum sometimes with dense pilosity, integument not entirely visible through pilosity; posterior upper margin modified into a conspicuously large process covered with velvety pilosity, its diameter at least $0.5 \times$ the tegula length. (14) T1 with dorsal surface of disc with sparse punctation, the punctures separated by $\geq 1 \mathrm{pd}$, posterior marginal zone smooth between punctures. Male. (15) Scape with diameter gradually enlarging toward the apex. (16) Flagellum reddish brown. F1-F11 not differing in diameter; F2 about as long as F3; F6-F11, in anterior view, with the anterior and posterior margins depressed, in posterior view with basal glabrous area at same level of remaining surface. (17) Metanotum with integument, in dorsal view, hidden by dense short plumose pilosity (Figure 7B). (18) Basal area of metapostnotum reddish brown, its length one-third of that of metanotum, covered by dense short plumose pilosity (Figure 7B). (19) Metepisternum as in the female. (20) 1 st and 2nd tarsomeres of foreleg with longest simple setae shorter than summed length of the three apical tarsomeres. (21) S3 with longitudinal sulcus only in the apical half, the posterolateral margin notched (Figure 8A). (22) S4 with medial protruding process, profile of process triangular in lateral view; basal portion glabrous; posterolateral margin notched, notch not extending to basal half of sclerite (Figure 8A). 


\section{Measurements}

Approximate body length: (12.0-13.1); maximum width of head: (3.2-4.1); intertegular distance: (3.5-4.1); length of forewing with the tegula: (9.6-11.2); length of forewing: (8.9-10.4).

\section{Comments}

In the specimens from Uiramutã and Amajari, in Roraima, the basal and central areas of the clypeus have a smooth surface between punctures. The specimen deposited in DZUP, with data label 'Batatais-SP $\backslash 27 / X I / 87 ’ \backslash$ J.S. Moure col.', has likely been mislabelled. It was probably collected by Moure in his trip to the Ilha de Maracá, Roraima, conducted in 1987.

\section{Distribution}

BRAZIL. Roraima: Amajari, Uiramutã. VENEZUELA: Unknown locality.

Megalopta guimaraesi Santos and Silveira, 2009

(Figures 1F, 2A, 3B, C, 7D, 9A, 15B)

Megalopta guimaraesi Santos and Silveira, 2009:10. Holotype female, Brazil: Minas Gerais, Jaboticatubas (DZMG, examined).

\section{Additional examined material \\ (45ㅇ, 8§). See Appendix 2.}

\section{Diagnosis}

The female differs from that of $M$. amoena by possessing in posterior upper margin of metepisternum a conspicuously large process covered with velvety pilosity; from $M$. chaperi by the longer basal area of metapostnotum, its length always longer than onethird of metanotum length (Figure 1F); from M. mura sp. n. by the mesoscutum, adjacent to parapsidial line, densely punctured $(<1 \mathrm{pd})$, punctuation sparser in direction to mesoscutal lip ( $\geq 1 \mathrm{pd}$ ) (Figure $3 \mathrm{~B}$ ), scutellum with posterior margin levelled to anterior margin of metanotum (Figure 3C), and by basal area of metapostnotum uniformly metallic green (Figure 1F). The male differs from that of $M$. chaperi by the longer basal area of metapostnotum, its length always longer than onethird of metanotum length and by sparse pilosity in metanotum (Figure 7D); from $M$. amoena by F6-F11 wider than remaining flagellomeres (Figure 9A), basal area of metapostnotum with longitudinal rugulosities in mid portion (Figure 7D), S3 with a weakly impressed longitudinal sulcus, S4 lacking pilosity basally, its apical margin strongly notched laterally; from $M$. mura sp. n. by the sparse punctures ( $\geq 1 \mathrm{pd})$ in mesoscutum adjacent to parapsidial line. 


\section{Description}

Female. (1) Mandible bidentate and with supplementary teeth. (2) Labral elevation sometimes with flattened surface. (3) Clypeus with surface between punctures on basal and central area variable, microreticulate or smooth. (4) Central portion of supraclypeal area with sparse punctation, punctures separated by $\geq 1 \mathrm{pd}$. (5) Antennae reddish brown. (6) Upper frons flat, not strongly declivous toward sulcus around median ocellus. (Figure 2A). (7) Ocellocular distance smaller than the F1 length. (8) Mesoscutum adjacent to the parapsidial line densely punctured $(<1 \mathrm{pd})$, punctation sparser in direction to mesoscutal lip ( $\geq 1 \mathrm{pd}$ ) (Figure 3B). (9) Scutellum with posterior margin levelled in relation to anterior margin of metanotum (Figure 3C). (10) Metanotum with integument, in oblique view, not hidden by short plumose pilosity. (11) Basal area of metapostnotum* sometimes metallic green, its length up to $0.7 \times$ that of metanotum, with few slightly impressed longitudinal rugulosities (Figure 1F). (12) Mesepisternum with contiguous punctation. (13) Metepisternum with dense pilosity, integument not visible through pilosity, posterior upper margin modified into a conspicuously large process covered with velvety pilosity, its diameter at least $0.75 \times$ the tegula length. (14) T1 with dorsal surface of disc sparsely punctured ( $\geq 1 \mathrm{pd}$ ), posterior marginal zone smooth between punctures. Male. (15) Scape with diameter gradually enlarging toward the apex. (16) Flagellum reddish brown; F1-F11 differing in diameter, F6-F11 wider than remaining flagellomeres (Figure 9A); F2 about as long as F3; F6-F11, in anterior view, with the anterior and posterior margins depressed, in posterior view, basally with basal glabrous area at same level of remaining surface. (17) Metanotum with integument, in dorsal view, not hidden by short plumose pilosity. (18) Basal area of metapostnotum metallic green, its length up to $0.9 \times$ that of metanotum, with few longitudinal rugulosities restricted to central area (Figure 7D). (19) Metepisternum with very dense pilosity, the integument not visible through pilosity, posterior upper margin modified into a conspicuously large process covered with velvety pilosity, its diameter at least $0.75 \times$ the tegula length. $(20)$ 1st and 2nd tarsomeres of foreleg with longest simple setae shorter than summed length of the three apical tarsomeres. (21) S3 with longitudinal sulcus slightly impressed, posterolateral margin slightly notched. (22) S4 with medial protruding process, profile of process triangular in lateral view; basal portion glabrous; posterolateral margin notched, notch not extending to basal half of sclerite.

\section{Measurements}

Approximate body length: (8.8-11.3); maximum width of head: (2.6-3.6) mm; intertegular distance: (2.7-3.8); length of forewing with the tegula: (8.8-10.6).

\section{Comments}

Specimens from eastern Brazil exhibit blackish integument, while those from central Brazil have a metallic green integument. However, one female from Camacan, Bahia, has a mostly black integument mixed green tints and one male from Rio de Janeiro is metallic green. 


\section{Distribution}

BRAZIL. Bahia: Camacan, Rio de Contas, Distrito Federal. Goiás: Alto Paraíso de Goiás, Caldas Novas, Formosa, Jataí, Planaltina. Maranhão: Açailândia, Balsas, Caxias. Mato Grosso: Alto Araguaia. Mato Grosso do Sul: Costa Rica. Minas Gerais: Bocaiúva, Corinto, Marliéria, Morro da Garça, Paracatu, São Gonçalo do Rio Abaixo, Três Marias, Viçosa. Paraná: Campo Mourão. Rio de Janeiro: Rio de Janeiro. São Paulo: Alvinlândia, Bauru, Cananéia (Figure 15B).

Megalopta mura sp. $\mathrm{n}$.

(Figures 1B, 3A, 3D-E, 7E-F, 8C, 15B)

\section{Diagnosis}

Different from $M$. chaperi by the length of basal area of metapostnotum in relation to metanotum length, its length never a third, and usually a half of metanotum length (Figure 3A). The female differs from $M$. amoena by presence in posterior upper margin of metepisternum of a conspicuously large process covered with velvety pilosity (Figure 1B) and the male by the F6-F11 wider than remaining flagellomeres; basal area of metapostnotum with longitudinal rugulosities present in central area (Figure 7E); S3 longitudinal sulcus slightly impressed (Figure 8C); S4 basally lacking pilosity, the apical margin strongly notched laterally (Figure 8C). Both sexes are distinguished from $M$. guimaraesi by the mesoscutum adjacent to parapsidial line with contiguous punctation, punctation becoming sparser towards the mesoscutal lip $(<1 \mathrm{pd})$ (Figure 3D); also the female differs by the scutellum with posterior margin raised in relation to anterior margin of metanotum (Figure 3E); basal area of metapostnotum often brownish in the centre and metallic green in the sides (Figures 3A, 7E).

\section{Description}

Female. (1) Mandible bidentate and with supplementary teeth. (2) Labral elevation with the central area slightly depressed in relation to the sides. (3) Clypeus with surface between punctures on basal and central area smooth. (4) Central portion of supraclypeal area with sparse punctation, punctures separated by $\geq 1 \mathrm{pd}$. (5) Antenna reddish brown. (6) Upper frons flat, not strongly declivous toward sulcus around median ocellus. (7) Ocellocular distance smaller than the F1 length. (8) Mesoscutum adjacent to the parapsidial line densely punctured, punctures contiguous, punctation becoming sparser towards mesoscutal lip ( $<1 \mathrm{pd}$ ) (Figure 3D). (9) Scutellum with posterior margin raised in relation to anterior margin of metanotum (Figure 3E). (10) Metanotum with integument, in oblique view, not hidden by short plumose pilosity. (11) Basal area of metapostnotum reddish brown with green metallic tints laterally, its length up to $0.6 \times$ that of metanotum, with longer longitudinal rugulosities restricted to central area (Figure 3A). (12) Mesepisternum with contiguous punctation. (13) Metepisternum with dense pilosity, integument not visible through pilosity; posterior upper margin modified into a conspicuously large process covered with velvety pilosity, its diameter at least $0.75 \times$ the tegula length (Figure 1B). (14) T1 with dorsal surface of disc sparsely punctured $(\geq 1 \mathrm{pd})$, posterior marginal zone smooth between 
punctures. Male. (15) Scape with diameter gradually enlarging toward the apex. (16) Flagellum reddish brown; F1-F11 differing in diameter, F6-F11 wider than remaining flagellomeres; F2 about as long as F3; F6-F11, in anterior view, with the anterior and posterior margins depressed, in posterior view, basally with basal glabrous area at same level of remaining surface. (17) Metanotum with integument, in dorsal view, not hidden by short plumose pilosity (Figure 7E). (18) Basal area of metapostnotum metallic green, its length up to $0.5 \times$ that of metanotum, longitudinal rugulosities restricted to central area (Figure 7E). (19) Metepisternum with very dense pilosity, the integument not visible through pilosity; posterior upper margin modified into a conspicuously large process densely covered with velvety pilosity, its diameter at least $0.75 \times$ the tegula length (Figure 7F). (20) 1 st and 2 nd tarsomeres of foreleg with longest simple setae shorter than summed length of the three apical tarsomeres. (21) S3 with longitudinal sulcus, slightly impressed posterolateral margin strongly notched (Figure 8C). (22) S4 with medial protruding process, profile of process triangular in lateral view, basal portion glabrous, posterolateral margin notched, notch not extending to basal half of sclerite (Figure 8C).

\section{Measurements}

Approximate body length: (9.8-11.0); intertegular distance: (3.1-4.0); maximum width of head: (2.9-3.1); length of forewing with tegula: (9.2-10.8).

\section{Type material}

Holotype female (DZUP): BRAZIL. Amazonas: 'BRASIL, Amazonas, Manaus, ZF-2 KM 34, Base LBA, 09.vii.2008, 100m, 2³5'33" S $\backslash 60^{\circ} 12^{\prime} 52^{\prime \prime}$ W arm. luz dossel\ P.C. Grossi col.'. Paratypes (42, 9ð): BRAZIL. Acre: 'Brasil, Acrel Acrelândial $10^{\circ} 04^{\prime} \mathrm{S} / 67^{\circ} 25^{\prime} \mathrm{W}$ ' 'Oliveira, Moratol \& Cunha leg\ Benzil acetato' (1ㅇ INPA). Amazonas: 'BRASIL, Amazonas $\backslash$ ESENA Juami-Japurá $02^{\circ} 19^{\prime} 09^{\prime}$ S $\backslash 68^{\circ} 25^{\prime}$ 16" W' '04-17 agosto 2005 L.S. Aquino leg.' (1q INPA); 'BRASIL, AM, Manaus, ZF2\ km-14. Torre, 023521S- $\ 600555 \mathrm{~W}, 19-21.1 i .2004 \backslash$ luz mista/BL, BLB, lençol' '40 mt alt. J.A. Rafael, \C.S. Motta, F.F. Xavier F' $\backslash$ \& A. Silva Fo , S. Trovisco' $\left(1 \delta^{\lambda}\right.$

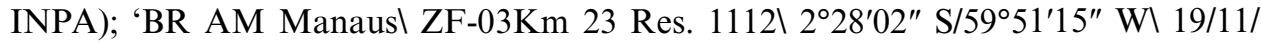
985 (RLD)\KLEIN BERT col.' 'FAZENDA ESTEIO' (19 INPA); 'BRASIL, Amazonas\BR 174 ZF6Km 9\ Data. 03.07-86\ Col. M.V.B. Garcia'Megalopta sp.' (1q MEUFV); 'BRAZIL, AMAZONAS MANAUS $\backslash$ Fazenda Porto Alegrel

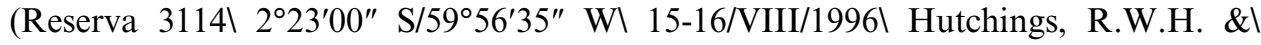
Hutchings, R.S.G. col.' 'AArm. tipo Pennsylvanial C/Cianeto de potássiol (Roger W. Hutchings)\ Luz Negra (UV-BL)' (1+ INPA); 'BRASIL, Amazonas, Manaus, Reserva Biológica de Campinal 12.vii.2008, 77m, 2 35'27" S $\backslash 60^{\circ} 1^{\prime} 51^{\prime \prime} \mathrm{W}$ arm. luz dossel\ P.C. Grossi col.' (2q DZUP); 'LO-4\ 1500m' 'Brasil Amazonas\ Reserva Duckel Am 010 Km26' '07-18 Dez 2005\ M.L. Oliveira \& E.R.F. Pereira' (1우 INPA); 'BRASIL, Amazonas\ Manaus, Res. Duckel XI.2003\ OL1- 700ms Vermelho' 'Arm. Suspensa $20 \mathrm{mts} \backslash$ A. Henriques et. al. Leg.' (19 INPA); 'BRASIL, AM, Manaus\ Reserva Ducke, Ig.I B. Branco, 15-18.iii.2004,' 'Arm. Malaise 04\A. Henriques et. al.' (1\% INPA); 'BRASIL, Amazonas, \ Parque Nac. 
do Jaúl 17-19/nov./2005' 'M.L. Oliveira \& E.R.I F. Pereira leg.l campinarana' (1q INPA); 'BR, AM, Pq. Nac. do Jaúl Rio Carabinami mg. dir $1^{\circ} 59^{\prime} \mathrm{S} / 51^{\circ} 32^{\prime} \mathrm{W} \backslash 11-12 /$ IV/1994\Motta, C. et al. col.' 'Luz mista mercúrio Luz negra BL e BLB $\backslash$ Lençol' (1ㅇ INPA); 'Brasil, Amazonas\ PARNA do Jaúl 19-III à 05-IV-\2003' 'M.L. Oliveira \&l J.A. Cunha leg.l Campinarana' (1 $\odot$ INPA); 'BRASIL, AM, Presidentel Figueiredo, BR 174, Ramal do Km-200, 27.i.2006' 'J.A. Rafael, F.F. Xavier, A. Silva F', D. M. M Mendes, \em luz' (1 $\left.\delta^{\circledR}\right),(I N P A)$; 'Brasil, Amazonas, Pres. Figueiredol Am 240, Km 12, Sítio Água Viva,\18-19/X/2006, Luz Mista,\Motta C.S. \& R.S. Hutchings’ (1ㅇ INPA); 'Brasil, Amazonas, Presidente Figueiredo, $\backslash$ AM 240, Km 24, $\backslash 2^{\circ} 1{ }^{\prime} 2.2^{\prime \prime} \mathrm{S} 59^{\circ}$ 49'35.8" W' '14-18.ix.2009, F.F.। Xavier Filho, Paladini, A.; Ciprandi, A.; Leivas, F.'

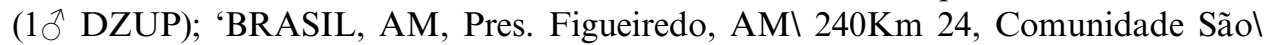

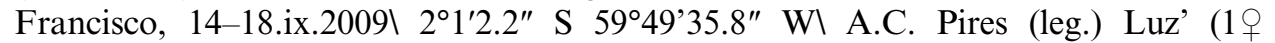
DZUP). Pará: 'Brasil, PA\ Capitão Poçol 19-22.xi.1984\ V.O. Becker col' (1ㅇ DZUP); 'Marajó P. Pedras\ 13.III-1978' 'Brasil Parál M F Torres' (1 9 MPEG); 'Brasil, Parál Serra Nortel Fofocal Col. Noturnal 18.IX. 1985' 'MPEG HYM\ 11005595' (19 MPEG); 'Brasil, Parál Serra Nortel N-1 SERRARIAI COL. NOTURNA $25 . X .1984$ ' 'Brasil Parál M. F Torres' 'MPEG HYM\11005589' (1ð MPEG); 'Brasil Parál Serra Nortel SERRARIAICOL. NOTURNAI 19-X-1984' 'MPEG HYM\11005583' (1q MPEG); 'Brasil Pará \São João de Pirabas \aperica \Ilha Conceição $22-X I I-1992$ ' 'Brasil Pará $J$ Dias' 'Armadilha\ de Luz' (1 $q$ MPEG); 'BRASIL: Parál Tucuruí - REMANSÃO\03-VIII-1980\eq Nunes de Mello' '5598' (1 9 INPA). Rondônia: 'Brasil, RO, Itapuã \do Oeste, Flona \o Jamari, 90m\9.146 S 63.012 ${ }^{\circ} \mathrm{W} \backslash$ 5.ix.2012, Cavichioli\ Melo, Rosa \& Santos' 'Armadilha\ Luminosa' (4ㅇ, DZUP). 'Ouro Pretol d'Oeste, RO,\29-X-1987\ C. Elias, leg.' 'ProjetoPol lonoroeste' (1ð DZUP); 'BRASIL: RO\ Porto Velho 180m\ 24-30.iv.1989\ V.O. Becker col' (2ᄋ DZUP); 'BRASIL:RO\ Porto Velho 180m\2-12.v.1989\ V.O. Becker' (1ㅇ DZUP). Roraima: 'Brasil, Roraima, Amajaril Tepequém Trilha Igarapél da Anta 0346'19.7" N"6145'21.6" W 649m 14-\ mai-09 11:00 Grigio, Jr.O\ Salicilato'MIRR 12685' (1 MIRR); 'Brasil, Roraima, Amajaril Tepequém Trilha Igarapél da Anta 0346'19.7" N"6145'21.6" W 649m 14-I mai-09 11:00 Grigio, Jr.O \Salicilato'MIRR 12686' (1q MIRR); 'Brasil, Roraima, $\backslash$ Rorainopólis, Bairro Novol Horizonte, 0056'25.8" N' '16²5'39.0" W 82m 28-mar-l 09 Gama Neto, J.L.'MIRR 11798' (19 MIRR). FRENCH GUIANA. Saint-Laurent-du-Maroni: 'FEVRIER' 'GUYANE\ NOUVEAU CHANTIER\BAS-MARONI' (1q DZUP). PERU. Huanuco: 'Tingo Marial Huan. Perul Nov. $281946 \backslash$ Alt. 2200 ft. J.C. Pallister $\backslash$ Coll. Donor\Frank Johnson' (19, DZUP). Junín: 'SATIPO-PERU 750 Mr. .12 .1948 ' (1 §̊, RMNH). Loreto: 'Peru, LO, Maynas, Alpahuayo-Mishana\KM 28-Ex light trapl 12vii01 Mario Callegari' 'col. CR col' (3ㅇ, CRC). San Martin: 'PERU, SM, Tarapoto, \Meliponário Rasmussen\ Near Taki-Wasi, 386m, 6²8, 819' S, 76²1,315' W Claus Rasmussen leg\IX-2002 Ex. light.' 'col. CR col' (2 +, CRC); 'PERU, SM, Tarapoto, \ Near Taki-Wasi, 386m, 6²8,819' S, 76²1,315' W\Claus Rasmussen leg\II-2003, Rasmussen leg.' 'col. CR col' (19, CRC); 'PERU, SM, Tarapoto,\Near River Shilcayo\0629\7622, 350 masl April 2003 Rasmussen' ‘col. CR col' (1q, CRC). SURINAME. Brokopondo: 'Surinamel Phedral 15 Nov-1946 IrSchals' (1q, RMNH). Para: 'Surinamel Zanderij\ O.P. Sardarel 15 Sept 1961' 'at light' (1ठ̄, RMNH). Sipaliwini: 'Museum Leiden\SURINAME\ Sipalawini\ 13-24. II.1966\G P Mees' (1亏̄, RMNH). Wageningen: 'Museum Leiden\ W. Suriname Exp.। 
Maratakka River Cupido (Indian vill.)\25.II.1971\at light D.C. Geijskes' (1 , RMNH).

\section{Comments}

The female from Acrelândia, Acre, was collected in a euglossine trap baited with benzil acetate.

\section{Distribution}

BRAZIL. Acre: Acrelândia. Amazonas: Japurá, Manaus, Novo Airão, Presidente Figueiredo. Pará: Capitão Poço, São João de Pirabas, Parauapebas, Tucuruí. Rondônia: Itapuã do Oeste, Ouro Preto do Oeste, Porto Velho. Roraima: Amajari, Rorainopólis. FRENCH GUIANA. Saint-Laurent-du-Maroni: Saint-Laurent-duMaroni. PERU. Huanuco: Tingo Maria. Junín: Satipo. Loreto: Maynas. San Martin: Tarapoto. SURINAME. Brokopondo: Phedra. Nickerie: Wageningen. Para: Zanderij. Sipaliwini: Bven Saramacca (Figure 15B).

\section{Etymology}

The specific epithet honours the 'Mura', the name for an ethnic group of South American natives, used here as a noun in apposition. They are known for navigating along extensive areas in the rivers Amazonas, Madeira and Purus. In their long history of contact with European settlers, this group has been repeatedly stigmatized and suffered from massacres, as well as demographic, linguistic and cultural losses. Today, they live at indigenous reserves and urban centres in northern Brazil (Amoroso 2009).

\section{The yanomami species group}

\section{Diagnosis}

The yanomami species group includes only two species, both described here as new, M. piraha sp. n. and M. yanomami sp. n. They can be identified by the following characters: posterior upper margin of metepisternum unmodified, lacking a velvety process; basal areal of metapostnotum smooth laterally and with a few longitudinal rugulosities restricted to mid portion. Megalopta piraha sp. n. is more widely distributed in the Amazon basin, while M. yanomami sp. n. is known only from Roraima and a single locality in eastern Pará (Figure 15C).

Megalopta piraha sp. $\mathrm{n}$.

(Figures 4B, 5B, C, 5F, 10D, 12E, 13E, 15C)

\section{Diagnosis}

It differs from $M$. yanomami sp. n. by the basal area of metapostnotum without defined external sulcus delimiting the longitudinal rugulosities, the integument light 
green (Figure 4B, 12E); the male is also distinguished by the scape enlarged gradually in direction to the apex (Figure 13E) and by flagellomeres without depressed and glabrous area (Figure 10D).

\section{Description}

Female. (1) Mandible bidentate and with supplementary teeth. (2) Labral elevation with the flattened surface. (3) Clypeus with surface between punctures on basal and central area microreticulate.(4) Central portion of supraclypeal area with dense punctation, punctures separated by $<1 \mathrm{pd}$, punctation becoming sparser in the lower portion ( $\geq 1 \mathrm{pd}$ ). (5) Antenna reddish brown (Figure 5B). (6) Upper frons flat, not strongly declivous toward sulcus around median ocellus. (7) Ocellocular distance smaller than the F1 length (Figure 5B). (8) Mesoscutum adjacent to the parapsidial line densely punctured, punctures contiguous on remainder of disc. (9) Scutellum with posterior margin raised in relation to anterior margin of metanotum. (10) Metanotum with integument, in oblique view, not hidden by short plumose pilosity (Figure 5F). (11) Basal area of metapostnotum reddish brown with green metallic tints, its length up to $0.8 \times$ that of metanotum, centrally with a single weak longitudinal rugulosity and a few shorter and slightly impressed ones in central portion, lateral surface smooth (Figures 4B, 5F). (12) Mesepisternum with contiguous punctation. (13) Metepisternum with sparse pilosity, integument visible through pilosity; posterior upper margin of metepisternum unmodified, lacking a velvety process. (14) T1 with dorsal surface of disc sparsely punctured ( $\geq 1 \mathrm{pd}$ ), posterior marginal zone microreticulate between punctures. Male. (15) Scape with diameter gradually enlarging toward the apex. (16) Flagellum pale yellow (Figure 13E), F1F11 not differing in diameter; F2 about as long as F3 (Figure 13E); F6-F11, in anterior view with the anterior and posterior margin depressed (Figure 10D), in posterior view with basal glabrous area at same level of remaining surface. (17) Metanotum with integument, in dorsal view, not hidden by short plumose pilosity. (18) Basal area of metapostnotum as in the female (Figure 12E). (19) Metepisternum as in the female. (20) 1st and 2nd tarsomeres of foreleg with longest simple setae shorter than summed length of the three apical tarsomeres. (21) S3 with longitudinal sulcus, the posterolateral margin notched. (22) S4 with medial protruding process, profile of process triangular in lateral view; basal portion glabrous; posterolateral margin notched, notch not extending to basal half of sclerite.

\section{Measurements}

Approximate body length: (13.0-14.8); maximum width of head: (3.4-4.3); intertegular distance: $(3.6-4.4) \mathrm{mm}$; length of forewing with the tegula: (11.7-13.2).

\section{Type material}

Holotype female (DZUP): BRAZIL. Amazonas: 'Manaus - AM \ PDBFF 29/11/89 M.L. Oliveira' '1008'. Paratypes (61, 13ð): BRAZIL. Amazonas: 'BRASIL, AM, Fonte Boal 023227S - 660408Wl 27.ix.2005, arm.luzl F.F. Xavier Fo' $(1 \hat{\jmath}$, 
INPA); 'MANAUS - AM PDBFF 21/12/89\M.L. OLIVEIRA' '1315’ (19 MEUFV); 'MANAUS - AM \ PDBFF 29/11/89\ M.L. OLIVEIRA' '1006' (19 MEUFV); 'MANAUS - AM\ PDBFF 23/1/90\ M.L. OLIVEIRA' '1516' (19 MEUFV); 'MANAUS - AM $\backslash$ PDBFF 23/1/90\ M.L. OLIVEIRA' '1914' (19 MEUFV); 'MANAUS - AM $\backslash$ PDBFF 8/1/90\ M.L. OLIVEIRA' '1448' (19 MEUFV); 'MANAUS - AM $\backslash$ PDBFF 24/VI/90\ M.L. OLIVEIRA' '2325' (19 MEUFV); 'MANAUS - AM \ PDBFF 8/VII/90\ M.L. OLIVEIRA' '2389' (19 MEUFV); 'BRASIL: AMAZONAS $\backslash$ MANAUS - P. DAS LARANJEIRAS $\backslash$ 02-VI-1981 $\backslash$ Eq: JORGE ARIAS $\backslash$ ARM. DE LUZ. 15M' (19 INPA); 'Manaus - AM $\backslash$ BRASIL, 10/ 12/88\ E.F. Morato' 'EUGENOLI No13' 'fornix' (1우 DZUP); ('Brasil. Amazonas। Reserva Duckel Am 010 Km26' '07-18 Dez 2005\ M.L. Oliveira \&l E.R.F. Pereira' 'LO-5\500m' (19 INPA); 'Brasil. Amazonas $\backslash$ Reserva Duckel Am 010 Km26’ '07-18 Dez 2005\M.L. Oliveira \&\ E.R.F. Pereira' 'LO-5\ 2500m' (1 9 INPA); 'BRASILAMAZONAS $\backslash$ MANAUS RES. DUCKE\II-1995 M.J.G. HOLYIN' (19 INPA); 'BRASIL AMAZONAS MANAUS $\backslash$ Fazenda Porto Alegre $\left(\right.$ Reserva $3114 \backslash 2^{\circ} 23^{\prime} 00^{\prime \prime}$ S/5956'35" W’ 14-15/VIII/1996\Hutchings, R. W. H. \&\Hutchings, R. S. G. col.' 'Arm. tipo Pennsylvanial C/cianeto de potássiol (Roger W. Hutchings) $\backslash$ Luz negra(UV-BL)' '0019536' (1요 INPA); 'BR AM MANAUS $\backslash$ ZF-03 km 23 Res. 1112 $2^{\circ} 26^{\prime} 02^{\prime \prime}$ S/5951' 15" W $\backslash 20 / I I / 1986$ (RLE)\KLEIN, BERT col.' 'FAZ.ESTEIO' 'MALAISE' (1 9 INPA); 'BRASIL AM Manaus ZF-2\ km-14, Torre, 023521S-\600655W, 18-21.v.2004\ lenço, luz mista e BLB, lençol' '40 mts altura, J.A. Rafaell F.B. Baccaro, F.F. Xavier $F^{\circ} \backslash$ \& A. Silva $F^{o}$.' (1q INPA); 'BRASIL AM Manaus ZF-2\ km-14, Torre, 023521S-I 600655W, 16-19.iv.2004\ luz mista/BLB, lençol' '40 mts altura, J.A. Rafael $\backslash$ C.S.

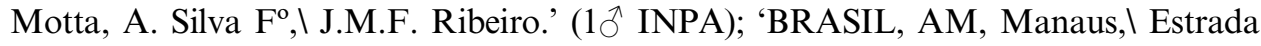
ZF-2, 01.x.2005,। arm. luz móvel, J.A. Rafael' 'F.F. Xavier F', R. Machadol A.A.

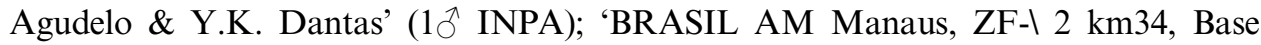
LBA, $\backslash 02^{\circ} 35^{\prime} 37^{\prime \prime} \mathrm{S}-60^{\circ} 12^{\prime} 39^{\prime \prime}$ W' '09-10.vii.2008. arm. luz nível do solo, J.A. Rafaell \& F.F. Xavier F' $^{\circ}$ (1ㅇ INPA); 'BRA, AM, Manaus PDBFF - Colosso $02^{\circ} 23^{\prime} 58^{\prime \prime} \mathrm{S}$ -

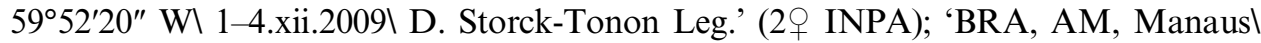

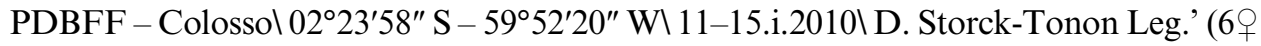

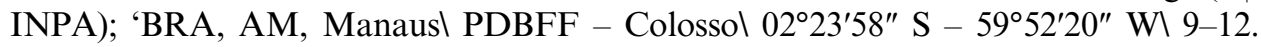
ii.2010 \D. Storck-Tonon Leg.' (13ㅇ INPA); 'BRA, AM, Manaus $\backslash$ PDBFF - Colossol 02 $23^{\prime} 58^{\prime \prime} \mathrm{S}-5^{\circ} 52^{\prime} 20^{\prime \prime} \mathrm{W} \backslash 28-30 . i v .2010 \backslash$ D. Storck-Tonon Leg.' (2ᄋ INPA); 'BRA,

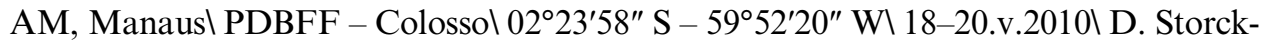
Tonon Leg.' (4 INPA); 'BRA, AM, Manaus $\backslash$ PDBFF - Colosso $02^{\circ} 23^{\prime} 58^{\prime \prime} \mathrm{S}-59^{\circ} 52^{\prime}$ 20" W $\backslash 23-27 . v i .2010 \backslash$ D. Storck-Tonon Leg.' (3 INPA); 'BRA, AM, Manaus $\mathrm{PDBFF}$

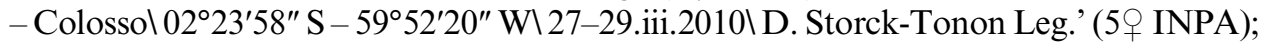
'BRASIL, Amazonas $\backslash$ Novo Aripuanã, Riol Madeira, Lago Xadá, Comunidade Belal Vista. Ponto 1.I Margem Esquerda' '05¹5'39" S/6042'32" W. 17-23.IV.2005\XavierFo, F.F.; $\backslash$ Godoi, F. \& Lourido, \A.M. leg.' (1 $\bigcirc^{\Uparrow}$ INPA); 'BRASIL, AM, MANAQUIRI \ LAGO JANUACÁ RIO \SOLIMÕES $\backslash 03^{\circ} 24^{\prime 2} 21^{\prime}$ S/60¹3'99” W' '12-13/IV/96\COL: DIAZ, G.A.' 'HYMENOPTERA: HALICTIDAE' (1ð INPA); 'BRASIL, Amazonas, Pq. Nac. Jau, Rio Carabinani, $\backslash$ 0159S-6132W, 07-17.iv.\1994, C. Motta e outros’ (4옹,

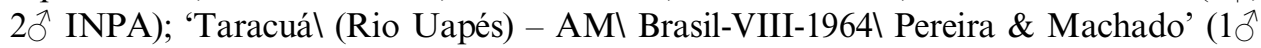
MZUSP). Pará: 'Canindél Rio Gurupi, Pará \IV.1963\ B. Malkin’ (1ठ MZUSP); 'BRASIL Pará Ourém\ Patauateua\21-VIII-1992' 'Brasil Parál B. Mascarenhas' (1ठ MPEG); 'BRASIL Pará Ourém\ Patauateua\1-IV-1994’`'Brasil Pará \B. Mascarenhas' (1ठ̄ MPEG); 'BRASIL, Parál Oriximiná, Porto Trombetas\ Platô Aviso\12/II/2008\ 
0554685/9806548 UTM \Y. Antonini, M.L. Oliveira leg.' (2甲 INPA); 'BRASIL, Parál Oriximiná, Porto Trombetas\ Platô Saracál 12/II/2008\0555958/9812404 UTM\Y. Antonini, M.L. Oliveira leg.' (4ㅇ INPA). Rondônia: 'Brasil Rondônial Ji-Paraná Gleba G\ Est. Rio Machadol 14.VI.1983' 'Brasil ROI J.R. Arias' (1ठَ MPEG);

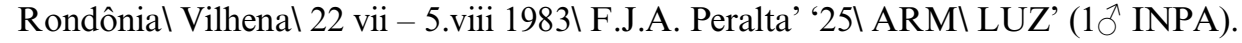

\title{
Distribution
}

BRAZIL. Amazonas: Fonte Boa, Manaquiri, Manaus, Novo Airão, Novo Aripuanã. Pará: Ourém, Oriximiná. Rondônia: Ji-Paraná, Vilhena (Figure 15C).

\section{Etymology}

The specific epithet honours the 'Pirahã' or 'Mura-Pirahã', the name for an ethnic group of South American natives, descendents of the 'Mura', used here as a noun in apposition. The Pirahã inhabit a tract of lands traversed by the Marmelos river and almost the entire length of the Maici river, located in the municipality of Humaitá, in Amazonas, northern Brazil (Gonçalves 2000).

Megalopta yanomami sp. $\mathrm{n}$.

(Figures 1C, 4A, 5E, 6B, 10C, 12D, 13C, D, 15C)

\begin{abstract}
Diagnosis
Differs from $M$. piraha by the basal area of metapostnotum with longitudinal rugulosities restricted to mid portion, external rugulosities strongly impressed and forming semicircles, the integument often dark green (Figure 4A); metanotum with contiguous punctation (Figure 5E); T1 densely punctured $(<1 \mathrm{pd})$. The male also differs by the scape uniformly enlarged (Figures 10C, 13C) and by flagellomeres with depressed and glabrous area (Figures 10C, 13D).
\end{abstract}

\section{Description}

Female. (1) Mandible bidentate and with supplementary teeth. (2) Labral elevation with lateral sides slightly raised in relation to central area. (3) Clypeus with surface between punctures on basal and central area smooth. (4) Central portion of supraclypeal area with dense punctation, the punctures separated by $<1 \mathrm{pd}$, except by a small impunctate area in the centre of the lower portion. (5) Antenna reddish brown. (6) Upper frons flat, not strongly declivous toward sulcus around median ocellus. (7) Ocellocular distance smaller than the F1 length. (8) Mesoscutum adjacent to the parapsidial line densely punctured, punctures contiguous, punctation becoming sparser towards mesoscutal lip ( $<1 \mathrm{pd})$. (9) Scutellum with posterior margin raised in relation to anterior margin of metanotum. (10) Metanotum with integument, in oblique view, not hidden by short plumose pilosity, with contiguous punctation (Figure 5E). (11) Basal area of metapostnotum metallic green, its length up to $0.7 \times$ 
that of metanotum, with longitudinal rugulosities restricted to central area (Figures 4A, 5E). (12) Mesepisternum with contiguous punctation. (13) Metepisternum with sparse pilosity, integument visible through pilosity; posterior upper margin of metepisternum unmodified, lacking a velvety process (Figure 1C). (14) T1 with dorsal surface of disc with contiguous to dense punctation $(<1 \mathrm{pd})$, posterior marginal zone smooth between punctures. Male. (15) Scape uniformly enlarged (Figures 10C, 13C). (16) Flagellum reddish brown (Figure 10C), F1-F11 not differing in diameter but with depressed and glabrous area in frontal view (Figures 10C, 13D); F2 about as long as F3 (Figure 10C); F6-F11, in anterior view, with the anterior and posterior margins depressed, in posterior view with basal glabrous area at same level of remaining surface. (17) Metanotum with integument, in dorsal view, not hidden by short plumose pilosity. (19) Basal area of metapostnotum dark metallic green, its length up to $0.8 \times$ that of metanotum, longitudinal rugulosities strongly impressed and enclosed laterally by two sulci (Figure 12D). (20) Metepisternum. As described for the female. (21) 1 st and 2 nd tarsomeres of foreleg with longest simple setae shorter than summed length of the three apical tarsomeres. (22) S3 with longitudinal sulcus, posterolateral margin notched. (23) S4 with medial protruding process, profile of process widely triangular in lateral view; basal portion glabrous; posterolateral margin notched, notch not extending to basal half of sclerite.

\section{Measurements}

Approximate body length: (11.5-14.2); maximum width of head: (3.5-4.5); intertegular distance: (3.2-4.4); length of forewing with tegula: (10.3-12.3).

\section{Type material}

Holotype female (INPA): BRAZIL. Roraima: 'BRASIL - Roraimal Rio Uraricoeral Ilha de Maracál 02-13.v.1987' 'J.A. Rafael\ J.E.B. Brasil L.S. Aquino' 'Armadilhal de Malaise'. Paratypes $\left(9+, 4{ }^{\Uparrow}\right)$ : BRAZIL. Pará: 'Brasil Parál Serra Nortel N1 Est. Serrarial 6-IX-1983' 'Luz U.V.' 'MPEG HYM 11005592' (1우, MPEG); 'Brasil Parál Serra Nortel MANGÂNES\C/Luzl 24-X-1984' 'Brasil Parál T. Pimentel' 'MPEG HYM $\backslash 11005587$ ' (19, MPEG); 'Brasil Parál Serra Nortel MANGÂNES $\backslash$ COL. NOTURNA\06-IX-1985' 'Brasil Parál Marcio Zanuto' 'MPEG HYM\11005600' (19, MPEG); 'Brasil Parál Serra Nortel N2 CANGAl 3-XI-1985' 'Brasil Parál N. Bittencourt' 'MPEG HYM 11005611 ' (1ð̄, MPEG); 'Brasil Parál Serra Nortel N1. Col. Luz 19-IX-1985' 'Brasil Parál J. Dias' 'MPEG HYM 11005596' (10̊, MPEG). Roraima: 'Brasil, Roraima, Amajari, $\backslash$ Tepequém, Trilha Igarapél da Anta $03^{\circ} 46^{\prime}$ 19.7" N' '6145'21.6" W 649m 14-I mai-09 11:00 Grigio, Jr. O\ Salicilato' 'MIRR 12678' (1을 MIRR);'BRASIL - Roraimal Rio Uraricoeral Ilha de Maracál 02-13. v.1987' 'J.A. Rafael\ J.E.B. Brasil\ L.S. Aquino' (4옹 INPA); 'Brasil: Roraimal Rio Uraricoeral Ilha de Maracá' 'Armadilhal de Luz' '21-30.xi.1987\ J.A. Rafael el equipe' (1+, INPA); 'Brasil Roraimal Tepequém\ Pousada SESCl 0345'186" N

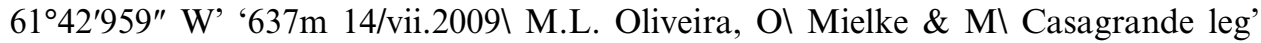
(1つ̂, INPA); 'BR RR Uiramutã, Rio Wailã 043750/600946\22/III/2007\ F.F. Xavier Filho, col.\ Luz Mista Mercúrio’ (1ô, INPA). 


\section{Distribution}

BRAZIL. Pará: Parauapebas. Roraima: Amajari, Uiramutã (Figure 15C).

\section{Etymology}

The specific epithet honours the 'Yanomami', the name for an ethnic group of South American natives, used here as a noun in apposition. The 'Yanomami' comprise a society of hunter-agriculturists of the tropical rainforest of northern Amazonia, whose contact with non-indigenous society over most of their territory has been relatively recent. Their territory covers an area of approximately $192,000 \mathrm{~km}^{2}$, located on both sides of the border between Brazil and Venezuela, in the OrinocoAmazon interfluvial region (affluents of the right shore of the Rio Branco and left shore of the Rio Negro). The total population of the 'Yanomami' in Brazil and Venezuela is today estimated to be around 26,000 people (Albert 1999).

\section{The byroni species group}

\section{Diagnosis}

The byroni group includes $M$. atlantica Santos \& Silveira, M. guarani sp. n., $M$. xavante sp. n., M. mapinguari sp. n., M. purpurata Smith, M. karitiana sp. n. and additional species previously placed in the subgenus Megalopta (Noctoraptor) Engel, Brooks and Yanega. It is distinguished from other species groups by the ocellocular distance equal to length of $\mathrm{F} 1$ and by the sparsely punctured mesoscutum posteriorly to mesoscutal lip ( $\geq 1 \mathrm{pd}$ ). The female differs from those of other groups by lacking the mandibular subapical and supplementary teeth and the basal macula in the inner surface of the mandible. The male is characterized by the F2 as wide as about twothirds of F3, dorsal surface of flagellomeres flattened to slightly depressed and by the protruding process of $\mathrm{S} 4$, in lateral view, digitiform or triangular and short. It is shown here that this group also contains species with a metallic green integument, differing from the previously described dark brown non-metallic species.

Bees in this group are rarely collected and most species are known from single specimens or small series. All known females in the byroni group have a morphology associated with non nest-making, parasitic behaviour. Biani and Wcislo (2007), in their work on $M$. byroni, consider that this group might behave as obligatory cleptoparasites or social parasites. Taking into consideration that female morphology in this group is more similar to that of macrocephalic females of nest-making species, it is more plausible to believe that they behave as social parasites. Macrocephalic females exhibit dominant queen-like behaviour over the non macrocephalic subordinate females.

Megalopta atlantica Santos and Silveira, 2009

(Figures 9F, 10B, 11E, 12B, 15D)

Megalopta atlantica Santos and Silveira, 2009:14. Holotype male, Brazil: Minas Gerais, Ipanema (DZUP, examined). 


\section{Diagnosis}

The male differs from $M$. guarani sp. n. and $M$. karitiana sp. n. by the medial protruding process of $\mathrm{S} 4$ digitiform in lateral view and by rugulosities present in central portion of basal area of metapostnotum; from M. mapinguari $\mathrm{sp}$. $\mathrm{n}$. by the mesosoma homogeneously black to brown and by medial protruding process of S4 lacking setae in the apex; from $M$. xavante sp. $\mathrm{n}$. by the integument black and by presence of rugulosities in the basal area of metapostnotum. This latter character also distinguishes $M$. atlantica from $M$. purpurata.

\section{Description}

Male. (15) Scape with diameter gradually enlarging toward the apex. (16) Flagellum blackish brown, F1-F11 not differing in diameter, F2 about two-thirds of F3 in length, F6-F11, in anterior view, with the anterior and posterior margins flat (Figures $9 \mathrm{~F}, 10 \mathrm{~B}$ ), in posterior view with basal glabrous area at same level of remaining surface. (17) Metanotum with integument, in dorsal view, not hidden by short plumose pilosity (Figure 11E). (18) Basal area of metapostnotum blackish brown; its length half of that metanotum; with longitudinal rugulosities present in central area, the rugulosities oblique towards the sides (Figure 11E). (19) Metepisternum with sparse pilosity, integument visible through pilosity; posterior upper margin of metepisternum unmodified, lacking a velvety process. (20) 1st and 2nd tarsomeres of foreleg with longest simple setae shorter than the summed length of the three apical tarsomeres. (21) S3 with longitudinal sulcus, posterolateral margin notched. (22) S4 with medial protruding process, profile of process digitiform in lateral view; basal portion glabrous; posterolateral margin notched, notch not extending to basal half of sclerite.

\section{Measurements}

Approximate body length: (12.5); intertegular distance: (3.35); maximum width of head: (3.12); length of forewing with tegula: (11.31).

Female. Unknown.

Distribution

BRAZIL. Minas Gerais: Ipanema (Figure 15D).

Megalopta guarani sp. $\mathrm{n}$.

(Figures 9C, 10E, F, 15D)

\section{Diagnosis}

The male differs from those of $M$. atlantica, M. purpurata, M. xavante sp. n., and $M$. mapinguari sp. $\mathrm{n}$. by the shape of the medial protruding process of $\mathrm{S} 4$, being short and having a triangular profile in lateral view (Figure 10E); from M. karitiana sp. n. by the colour of the integument, metallic green in the head and mesosoma with coppery tints (Figures 9C, 10F) and reddish brown on metasoma. 


\section{Description}

Male. (15) Scape with diameter gradually enlarging toward the apex. (16) Flagellum brown, except F2 reddish brown (Figure 9C), F1-F11 not differing in diameter; F2 about two-thirds of F3 in length (Figure 9C); F6-F11, in anterior view, with the anterior and posterior margins flat, in posterior view with basal glabrous area at same level of remaining surface. (17) Metanotum with integument, in dorsal view, not hidden by short plumose pillosity (Figure 10F). (18) Basal area of metapostnotum green metallic; its length $0.75 \times$ that of metanotum; smooth without longitudinal rugulosities (Figure 10F). (19) Metepisternum with sparse pilosity, integument visible through pilosity; posterior upper margin of metepisternum unmodified, lacking a velvety process (20) 1st and 2nd tarsomere of foreleg with longest simple setae shorter than the summed length of the three apical tarsomeres. (21) S3 with longitudinal sulcus, posterolateral margin notched. (22) S4 with medial protruding process, profile of process minute triangular in lateral view (Figure 10E); basal portion glabrous; posterolateral margin notched, notched not extending to basal half of sclerite.

\section{Measurements}

Approximate body length: (10.7); intertegular distance: (2.9); maximum width of head: (2.6); length of forewing with tegula: (9.0); length of forewing: (8.3).

Female. Unknown.

\section{Type material}

Holotype male (MPEG): BRAZIL. Mato Grosso: 'Brasil MT\Chap. dos Guimarães\ Colégio Agr. Buriti\ 8 a 13-II-1986\ Col. I.S. Gorayeb' 'Armadilha\ Malayse'.

\section{Distribution}

BRAZIL. Mato Grosso: Chapada dos Guimarães (Figure 15D).

\section{Etymology}

The specific epithet honours the 'Guarani', the name for an ethnic group of natives used here as a noun in apposition. Since the mid-1920s, for the Guarani subgroup Kaiowa, there has been a continuous process of expropriation of Guarani lands, which are constantly threatened by farmers (Almeida and Mura 2003).

\section{Megalopta karitiana sp. n.}

(Figures 11A, 15D)

\section{Diagnosis}

The male differs from those of $M$. atlantica, $M$. purpurata, $M$. xavante sp. n., and M. mapinguari sp. $\mathrm{n}$. by the minute medial protruding process of $\mathrm{S} 4$, with a triangular profile in lateral view; from M. guarani sp. n. by the dark brown integument with metallic green reflections, and the dark brown metasoma with purple tints. 


\section{Description}

Male. (15) Scape with diameter gradually enlarging toward the apex. (16) Flagellum blackish; F1-F11 not differing in diameter; F2 about two-thirds of F3 in length. (17) Metanotum with integument, in dorsal view, not hidden by short plumose pillosity. (18) Basal area of metapostnotum blackish, its length $0.6 \times$ that of metanotum; smooth and without longitudinal rugulosities along its surface (Figure 11A). (19) Metepisternum with sparse pilosity, integument visible through pilosity; posterior upper margin of metepisternum unmodified, lacking a velvety process. (20) 1st and 2nd tarsomeres of foreleg with longest simple setae shorter than the summed length of the three apical tarsomeres. (21) S3 with longitudinal sulcus, posterolateral margin notched. (22) S4 with medial protruding process present, minute, its profile triangular in lateral view, basal portion glabrous; posterolateral margin notched, notch not extending to basal half of sclerite.

\section{Measurements}

Approximate body length: (14.8); intertegular distance: (3.8); maximum width of head: (3.7); length of forewing with tegula: (12.7).

Female. Unknown.

\section{Type material}

Holotype male (DZUP): BRAZIL. Rondônia: 'Brasil, RO, Itapuã \do Oeste, Flonal do Jamari, $110 \mathrm{~m} \backslash 9.260^{\circ} \mathrm{S} 62.913^{\circ} \mathrm{W}, \backslash 4$.ix.2012, Cavichioli, \ Melo, Rosa \& Santos' 'Armadilhal Luminosa'.

\section{Distribution}

BRAZIL. Rondônia: Itapuã do Oeste (Figure 15D).

\section{Etymology}

The specific epithet honours the 'Karitiana', the name for an ethnic group of natives, used here as a noun in apposition. The 'Karitiana' experienced a brutal demographic decline after contact with the whites. Indeed, the anthropologist Darcy Ribeiro considered them extinct in 1957, however the current population numbers around 320 individuals (Storto and Velden 2005).

\section{Megalopta mapinguari sp. $\mathrm{n}$.}

(Figures 9D, 11B, C, 15D)

\section{Diagnosis}

The male differs from those of $M$. guarani sp. n. and M. karitiana sp. n. by the shape of the medial protruding process of $\mathrm{S} 4$, its profile digitiform in lateral view; from $M$. 
atlantica, M. purpurata and $M$. xavante sp. n. by the mesosoma homogeneously metallic green and by lacking setae in the apex of medial protruding process of S4.

\section{Description}

Male. (15) Scape with diameter gradually enlarging toward the apex. (16) Flagellum blackish; F1-F11 not differing in diameter; F2 about two-thirds of F3 in length (Figure 9D); F6-F11, in anterior view, with the anterior and posterior margins flat, in posterior view with basal glabrous area at same level of remaining surface. (17) Metanotum with integument, in dorsal view, not hidden by short plumose pillosity (Figure 11C). (18) Basal area of metapostnotum metallic green, its length $0.5 \times$ that of metanotum, longitudinal rugulosities present in the mid portion (Figure 11C). (19) Metepisternum with sparse pilosity, integument visible through pilosity; posterior upper margin of metepisternum unmodified, lacking a velvety process. (20) 1st and 2nd tarsomeres of foreleg with longest simple setae shorter than the summed length of the three apical tarsomeres. (21) S3 with longitudinal sulcus, posterolateral margin notched (Figure 11B). (22) S4 with medial protruding process, profile of process digitiform in lateral view (Figure 11B); basal portion glabrous; posterolateral margin notched, notch not extending to basal half of sclerite.

\section{Measurements}

Approximate body length: (12.4); intertegular distance: (3.8); maximum width of head: (2.9); length of forewing with tegula: (10).

Female. Unknown.

\section{Type material}

Holotype male (DZUP): BRAZIL. Acre: 'Faz. Catuaba - UFACl armadilha luminosal capoeira'.

\section{Comments}

The collecting date of the type specimen is unknown. The species can be easily recognized by intense metallic green reflections, sometimes mixed with black tints in integument, except for predominantly blackish metasoma.

\section{Distribution}

BRAZIL. Acre: Rio Branco (Figure 15D).

\section{Etymology}

The specific epithet honours the 'Mapinguari', used here as a noun in apposition. The 'Mapinguari', a Brazilian folklore character, is popularly known as a monster that lives in the Amazon Rainforest. 
Megalopta purpurata Smith, 1879

(Figures 10A, 11F, 12C, 15D)

Megalopta purpurata Smith, 1879: 48. Holotype male, Brazil: Amazonas, Tefé ('Ega') (BMNH, not directly examined).

\section{Diagnosis}

The male differs from those of $M$. guarani sp. n. and $M$. karitiana sp. $\mathrm{n}$. by the digitiform medial protruding process of S4, in lateral view; from $M$. mapinguari sp. $\mathrm{n}$ and $M$. xavante sp. n. by the mesosoma homogeneously blackish (Figures 11F, 12C); also distinguished from $M$. mapinguari by medial protruding process of S4 lacking setae in the apex; from $M$. atlantica by the absence of rugulosities in basal area of metapostnotum (Figure 12C).

\section{Description}

Male. (15) Scape missed. (16) Flagellum missed (Figure 10A). (17) Metanotum with integument, in dorsal view, not hidden by short plumose pilosity (Figure 11F). (18) Basal area of metapostnotum blackish; its length less than half of metanotum (Moure 1958); smooth, without rugulosities (Figure 12C). (19) Metepisternum with sparse pilosity, integument visible through pilosity; posterior upper margin of metepisternum unmodified, lacking a velvety process. (20). 1st and 2nd tarsomere of foreleg unobserved. (21) S3 with longitudinal sulcus, posterolateral margin notched. (22) S4 with medial protruding process, profile of process digitiform in lateral view; basal portion glabrous; posterolateral margin notched, notch not extending to basal half of sclerite.

Female. Unknown.

\section{Comments}

The type was not examined directly, but through photographs obtained from the British Museum (BMNH). Its inclusion in the byroni species group was based on the following features: body coloration without metallic green reflections and S4 in basal area with a digitiform medial protruding process. Some characteristics of this species were extracted from Moure's (1958) redescription.

Distribution

BRAZIL. Amazonas: Tefé (Figure 15D).

Megalopta xavante sp. $\mathrm{n}$.

(Figures 3F, 4F, 5A, 9E, 11D, 12A, 15D)

\section{Diagnosis}

Differs from $M$. guarani sp. n. and $M$. karitiana sp. n. by medial protruding process of S4 digitiform in lateral view; from $M$. atlantica, M. purpurata and $M$. mapinguari 
sp. n. by integument mostly reddish brown with metallic green tints on head and mesosoma (Figures 3F, 4F).

\section{Description}

(1) Mandible simple and lacking supplementary teeth (Figure 4F). (2) Labral elevation in central portion, with rounded elevated area in relation to the sides. (2) Clypeus with surface between punctures on basal and central area smooth, the apical macula reddish brown. (4) Central portion of supraclypeal area with sparse punctation, punctures separated by $\geq 1$ pd. (5) Antenna reddish brown (Figure 4F). (6) Upper frons flat, not strongly declivous toward sulcus around median ocellus. (7) Ocellocular distance equal to length of F1 (Figure 4F). (8) Mesoscutum adjacent to the parapsidial line densely punctured, punctures contiguous, punctation becoming sparser towards the mesoscutal lip ( $<1 \mathrm{pd})$. (9) Scutellum with posterior margin raised in relation to anterior margin of metanotum. (10). Metanotum with integument, in oblique view, not hidden by short plumose pilosity. (11) Basal area of metapostnotum reddish brown, its length $0.4 \times$ that of metanotum, with smooth surface, without longitudinal rugulosities (Figure 3F). (12) Mesepisternum with contiguous punctation. (13) Metepisternum with sparse pilosity, integument visible through pilosity, posterior upper margin unmodified, lacking a velvety process. (14) $\mathrm{T} 1$ with dorsal surface of disc sparsely punctured $(\geq 1 \mathrm{pd})$, posterior marginal zone microreticulated between punctures. Male. (15) Scape with diameter gradually enlarging toward the apex (Figure 9E). (16) Flagellum reddish brown, except F2 and F3 lighter than the others (Figure 9E); F1-F11 not differing in diameter; F2 about twothirds of F3 in length (Figure 9E); F6-F11, in anterior view, with the anterior and posterior margins flat, in posterior view with basal glabrous area at same level of remaining surface. (17) Metanotum with integument, in dorsal view, not hidden by short plumose pilosity (Figure 11D). (18) Basal area of metapostnotum reddish brown with metallic green tints; its length about $0.7 \times$ that of metanotum; the longitudinal rugulosities slightly impressed centrally (Figure 11D). (19) Metepisternum as in the female. (20) 1 st and 2 nd tarsomeres of foreleg with longest simple setae shorter than summed length of the three apical tarsomeres. (21) S3 with longitudinal sulcus, posterolateral margin notched. (22) S4 with medial protruding process, profile of process digitiform in lateral view; basal portion glabrous; posterolateral margin notched, notched not extended to basal half of sclerite.

\section{Measurements}

Approximate body length: (10.7-10.7); intertegular distance: (3-3.4); maximum width of head: (2.9-3.3); length of forewing with tegula: (9.5).

\section{Type material}

Holotype female (RPSP): BRAZIL. Mato Grosso: 'Nova Xavantina MT BR \ CUNX - bacaba luz। 14/I/99\ Canolho A.' Paratype male: BRAZIL. Mato Grosso: 'Nova Xavantinal MT BR\ CUNX - Bacaba luzl 30/I/98 Legl Barreira RL'. 
Distribution

BRAZIL. Mato Grosso: Nova Xavantina (Figure 15D).

\section{Etymology}

The specific epithet honours the 'Xavante', the name for an ethnic group of natives, used here as a noun in apposition. The Xavantes live in nine indigenous areas which are part of the territory they traditionally occupied for at least 180 years, in eastern Mato Grosso. The region where they live has suffered the environmental impact of extensive cattle ranching since the 1960s, an impact which is almost certainly irreversible. From the 1980s the impact has been intensified by the spread of giant grain farms, especially soybeans produced for export (Graham 2008).

\section{The sodalis species group}

\section{Diagnosis}

The sodalis species group includes: . cuprea, M. munduruku sp. n. and M. sodalis. Members of this species group can be recognized by having the mid portion of the basal area of the metapostnotum with depressed triangular area with longitudinal rugulosities branching from central rugulosities, or with transverse depression in $M$. munduruku sp. n., and by having the posterior upper margin of the metepisternum unmodified, lacking a velvety process in both sexes. Furthermore, this species group exhibits a large amount of intraspecific variation in the shape of the basal elevation of the labrum and in the basal area of the metapostnotum.

M. cuprea occurs in Bolivia and northern Brazil (Figure 16A), while M. mundur$u k u$ sp. n. is found only in northern Brazil (Figure 16B) and M. sodalis is widely distributed (Figure 16C).

Megalopta cuprea Friese, 1911

(Figures 4D, 13A, 16A)

Megalopta cuprea Friese, 1911: 453. Lectotype female, Bolivia: Mapiri (ZMB, examined).

Additional examined material

(5q, 1ठ). See Appendix 2.

\section{Diagnosis}

The female differs from that of $M$. munduruku sp. $\mathrm{n}$. by mid depression extending to posterior margin in basal area of metapostnotum (Figure 4D) and the male, by basal area of metapostnotum with longer and strongly impressed longitudinal rugulosities (Figure 13A); both sexes can be distinguished from M. sodalis by head and thorax mostly dark brown, lacking metallic reflections. 

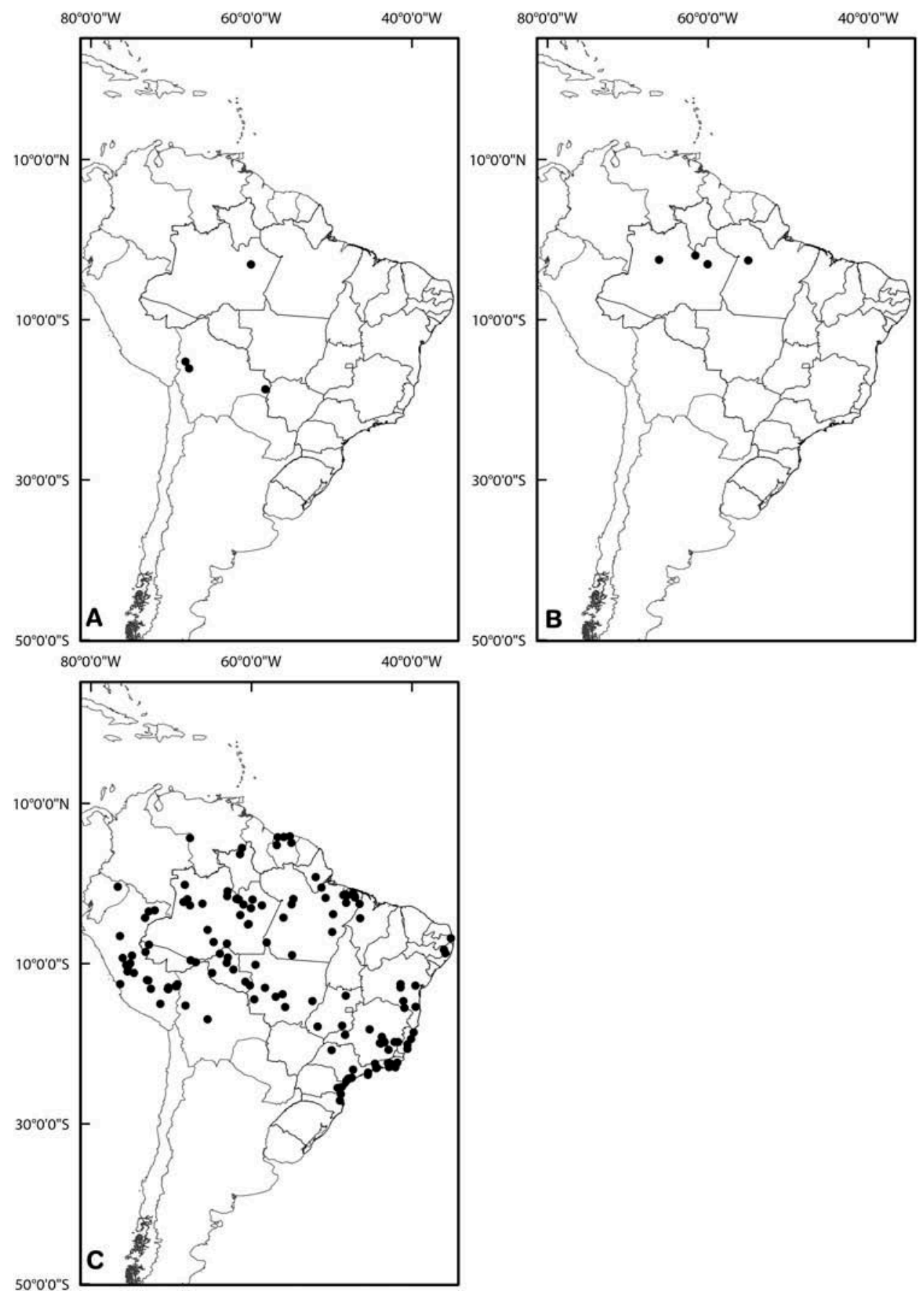

Figure 16. Distribution records of Megalopta species. (A) M. cuprea Friese; (B) M. munduruku sp. n; (C) M. sodalis Vachal. 


\section{Description}

Female. (1) Mandible bidentate and with supplementary teeth. (2) Labral elevation with lateral surface strongly elevated in relation to central portion. (3) Clypeus with surface between punctures on basal and central area microreticulated. (4) Central portion of supraclypeal area with dense punctation, punctures separated by $<1 \mathrm{pd}$. (5) Antennae with scape brown, pedicel and flagellomeres reddish brown. (6) Upper frons flat, not strongly declivous toward sulcus around median ocellus. (7) Ocellocular distance smaller than the F1 length. (8) Mesoscutum adjacent to parapsidial line densely punctured, punctures contiguous, punctation becoming sparser towards mesoscutal lip ( $<1 \mathrm{pd})$. (9) Scutellum with posterior margin raised in relation to anterior margin of metanotum. (10) Metanotum with integument, in oblique view, not hidden by short plumose pilosity (Figure 4D). (11) Basal area of metapostnotum blackish, its length at least $0.7 \times$ that of metanotum; with longer and imbricated longitudinal rugulosities strongly impressed in the central area (Figure 4D). (12) Mesepisternum with contiguous punctation. (13) Metepisternum with sparse pilosity, integument visible through pilosity; posterior upper margin of metepisternum unmodified, lacking a velvety process. (14) T1 with dorsal surface of disc densely punctured ( $<1 \mathrm{pd})$, posterior marginal zone microreticulated between punctures. Male. (15) Scape with diameter gradually enlarging toward the apex. (16) Flagellum reddish brown; F1-F11 not differing in diameter; F2 about as long as F3; F6-F11, in anterior view, with the anterior and posterior margins depressed, in posterior view with basal glabrous area at same level of remaining surface. (17) Metanotum with integument, in dorsal view, not hidden by short plumose pilosity. (18) Basal area of metapostnotum blackish, its length at least $0.7 \times$ that metanotum, medially with longer longitudinal rugulosities, laterally with microreticulated surface (Figure 13A). (19). Metepisternum as in the female. (20) 1st and 2nd tarsomeres of foreleg with longest simple setae smaller than summed length of the three apical tarsomeres. (21) S3 with longitudinal sulcus, posterolateral margin notched. (22) S4 with medial protruding process, profile of process triangular in lateral view; basal portion glabrous; posterolateral margin notched, notch not extended to basal half of sclerite.

\section{Measurements}

Approximate body length: (13.2-14.5); maximum width of head: (3.6-3.8); intertegular distance: (4.0-4.3); length of forewing with tegula: (13.0-14.3).

\section{Comments}

All studied specimens were from Bolivia. The only record of this species in Brazil was published by Friese (1923:3), based on a female from 'Manaos'. However, no additional specimens from Brazil have been found during this study and Friese (1926:124) does not include the Brazilian record in his treatment of $M$. cuprea.

\section{Distribution}

BOLIVIA. La Paz: Mapiri, Nigrillani, Santa Cruz: Espejo. BRAZIL. Amazonas: Manaus (Friese 1923) (Figure 16A). 


\section{Megalopta munduruku sp. n.}

(Figures 4C, 12F, 16B)

\section{Diagnosis}

The female differs from those of $M$. cuprea and M. sodalis by basal area of metapostnotum with mid depression restricted to anterior half, not extending to posterior margin (Figure 4C) and the male, by basal area of metapostnotum with shorter and weakly impressed longitudinal rugulosities (Figure 12F).

\section{Description}

Female. (1) Mandible bidentate and with supplementary teeth. (2) Labral elevation with lateral surface slightly raised in relation to central portion, the surface slightly bilobated basally. (3) Clypeus with surface between punctures on basal and central area microreticulated. (4) Central portion of supraclypeal area with sparse punctation, punctures separated by $\geq 1$ pd. (5) Antenna reddish brown. (6) Upper frons flat, not strongly declivous toward sulcus around median ocellus. (7) Ocellocular distance smaller than the F1 length. (8) Mesoscutum, adjacent to parapsidial line densely punctured, punctures contiguous, punctation becoming sparser towards mesoscutal lip ( $<1 \mathrm{pd})$. (9) Scutellum with posterior margin raised in relation to anterior margin of metanotum. (10) Metanotum with integument, in oblique view, not hidden by short plumose pilosity (Figure 4C). (11) Basal area of metapostnotum metallic green with reddish brown tints; its length at least $0.6 \times$ that of metanotum; with mid depression restricted to anterior half, not extending to posterior margin, longitudinal rugulosities restricted to central area (Figure 4C). (12) Mesepisternum with contiguous punctation. (13) Metepisternum with sparse pilosity, integument visible through pilosity; posterior upper margin of metepisternum unmodified, lacking a velvety process. (14) T1 with dorsal surface of disc densely punctured $(<1 \mathrm{pd})$, posterior marginal zone microreticulated between punctures. Male. (15) Scape with diameter gradually enlarging toward the apex. (16) Flagellum reddish brown; F1-F11 not differing in diameter; F2 about as long as F3; F6-F11, in anterior view with the anterior and posterior margins depressed, in posterior view with basal glabrous area at same level of remaining surface. (17) Metanotum with integument, in dorsal view, not hidden by short plumose pilosity (Figure 12F). (18) Basal area of metapostnotum with shorter and weakly impressed longitudinal rugulosities (Figure 12F). (19) Metepisternum as in the female. (20) 1 st and 2nd tarsomeres of foreleg with longest simple setae shorter than the summed length of the three apical tarsomeres. (21) S3 with longitudinal sulcus, posterolateral margin notched. (22) S4 with medial protruding process, profile of process triangular in lateral view; basal portion glabrous; posterolateral margin notched, notch not extending to basal half of sclerite.

\section{Measurements}

Approximate body length: (13.3-14.0); maximum width of head: (4.0-4.8); intertegular distance: (4.4-4.8); length of forewing with the tegula: (13.3-14.0). 


\section{Type material}

Holotype female (INPA): BRAZIL: 'BRASIL, PA, Belterra\FLONA Tapajós, 100m

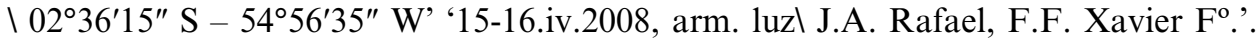

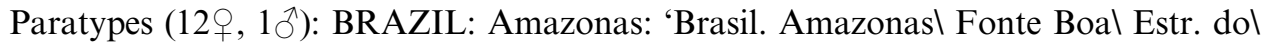

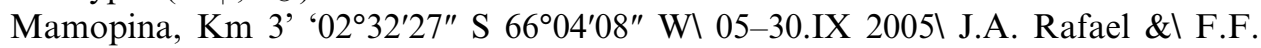
Xavier-Filhol Em luz' (2ㅇ, INPA); 'BRASIL: '2070' 'MANAUS-AM $\backslash$ PDBFF 25/ IV/90\ M.L. OLIVEIRA' (1 9, MEUFV); '2072' 'MANAUS-AM $\backslash$ PDBFF 25/IV/90\ M.L. OLIVEIRA' 'Megalopta spp.I det. G. Melo 1996'(1ㅇ, MEUFV); 'BRASILAMAZONAS $\backslash$ MANAUS-FUA $\backslash$ 23/II/82 $\backslash$ MORAIS. J.W.' (19, INPA); 'BRASIL, Amazonas, Pq\ Nac. Jaú R. Carabiani, \0159S-6132W, 07-17.iv.\1994. C. Motta e outros' (1 $\partial^{\lambda}$, INPA) 'BRA, AM, Manaus PDBFF - Colosso $02^{\circ} 23^{\prime} 58^{\prime \prime}$ S - 59 $52^{\prime} 20^{\prime \prime}$ $\mathrm{W} \backslash 11-15.1 .2010 \backslash$ D. Storck-Tonon Leg.'. (1요 INPA); 'BRA, AM, Manaus $\backslash$ PDBFF

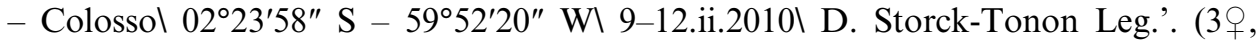
INPA); 'BRA, AM, Manaus $\backslash$ PDBFF - Colosso $02^{\circ} 23^{\prime} 58^{\prime \prime} \mathrm{S}-59^{\circ} 52^{\prime 2} 20^{\prime \prime} \mathrm{W} \backslash 18-20$. v.2010 \D. Storck-Tonon Leg.'. (19, INPA); 'BRA, AM, Manaus $\backslash$ PDBFF - Colosso $\backslash 02^{\circ} 23^{\prime} 58^{\prime \prime} \mathrm{S}-5^{\circ} 52^{\prime} 20^{\prime \prime} \mathrm{W} \backslash 23-27 . v i .2010 \backslash \mathrm{D}$. Storck-Tonon Leg.'. (2ᄋ, INPA); 'Br, AM, Pres. Figueiredol Am. $240 \mathrm{Km} 24 \backslash$ Com. São Francisco $02^{\circ} 01^{\prime} 05^{\prime \prime} \mathrm{S} / 59^{\circ} 49^{\prime} 59^{\prime \prime}$ W' '26/vii-03/viii/2005,\ Armadilha luz mistal F.F. Xavier F' ${ }^{\circ}$ G.M.I Lourido, R. Machado’ (1 9 , INPA).

\section{Distribution}

BRAZIL. Amazonas: Fonte Boa, Manaus, Novo Airão. Pará: Belterra (Figure 16B).

\section{Etymology}

The specific epithet honours the 'Munduruku', the name for an ethnic group of natives used here as a noun in apposition. Historically a people with a warrior tradition, the Munduruku culturally dominated the region of the valley of the Tapajós River, Brazil. Today, the wars they wage are to guarantee the integrity of their territory, threatened by pressures from the illegal activities of gold-panning, hydroelectric projects, and the construction of a great waterway on the Tapajós river (Ramos 2003).

\section{Megalopta sodalis (Vachal 1904)}

(Figures 4E, 13C, 16C)

Halictus sodalis Vachal, 1904:114. Holotype female, Brazil: Santa Catarina, Joinville (MNHP, not examined).

Halictus fornix Vachal, 1904:114. Holotype female, Peru: Huallaga, Rio Mixiollo $1200 \mathrm{~m}$ (MNHP, not examined). New synonymy.

Halictus aethautis Vachal, 1904:115. Holotype male, Peru: Lima, Callanga. (MNHP, not examined).

\section{Examined material}

(525q, 111ð). See Appendix 2. 


\section{Diagnosis}

This species differs from $M$. cuprea only by the metallic green integument; from females of M. munduruku sp. n. by basal area of metapostnotum with mid depression extending to posterior margin (Figure 4E), and from males, by longer and strongly impressed longitudinal rugulosities in the basal area of metapostnotum (Figure 13C).

\section{Description}

Female. (1) Mandible bidentate and with supplementary teeth. (2) Labral elevation* with flattened, slightly depressed or with lateral surface strongly raised in relation to central portion. (3) Clypeus with surface between punctures on basal and central area variable, often microreticulated and sometimes smooth. (4) Central portion of supraclypeal area with sparse punctation, the punctures are separated by $\geq 1 \mathrm{pd}$. (5) Antennae reddish brown. (6) Upper frons flat, not strongly declivous toward sulcus around median ocellus. (7) Ocellocular distance smaller than the F1 length. (8) Mesoscutum, adjacent to parapsidial line densely punctured, punctures contiguous, punctation becoming sparser towards mesoscutal lip ( $<1 \mathrm{pd})$. (9) Scutellum with posterior margin raised in relation to anterior margin of metanotum. (10) Metanotum with integument, in oblique view, not hidden by short pilosity (Figure 4E). (11) Basal area of metapostnotum metallic green, its length 0.55 to $0.8 \times$ that of metanotum, with longer and strongly impressed longitudinal rugulosities in mid portion (Figure 4E). (12) Mesepisternum with contiguous punctation. (13) Metepisternum with sparse pilosity, integument visible through pilosity; posterior upper margin of metepisternum unmodified, lacking a velvety process. (14) T1 with dorsal surface of disc densely punctured $(<1 \mathrm{pd})$, posterior marginal zone microreticulated between punctures. Male. (15) Scape with diameter gradually enlarging toward the apex. (16) Flagellum reddish brown; F1-F11 not differing in diameter; F2 about as long as F3; F6-F11, in anterior view with the anterior and posterior margins depressed, in posterior view with basal glabrous area at same level of remaining surface. (17) Metanotum with integument, in oblique view, not hidden by short plumose pilosity (Figure 13C). (18) Basal area of metapostnotum metallic green, its length at least $0.8 \times$ that of metanotum, medially with longer longitudinal rugulosities, laterally with smooth surface (Figure 13C). (19). Metepisternum as in the female. (20) 1 st and 2 nd tarsomeres of foreleg with longest simple setae shorter than the summed length of the three apical tarsomeres. (21) S3 with longitudinal sulcus, posterolateral margin notched. (22) S4 with medial protruding process, profile of process triangular in lateral view; basal portion glabrous; posterolateral margin notched, notch not extending to basal half of sclerite.

\section{Measurements}

Approximate body length: (11.4-20.7); maximum width of head: (3.4-4.5); intertegular distance: (3.5-5.4); length of forewing with tegula: (10.8-16.1). 


\section{Comments}

One specimen from Itu, São Paulo, and another from Nova Lima, Minas Gerais (Santos and Silveira 2009), exhibit a dark body coloration. The specimens from Mucugê, Bahia and another from Itatiaia, Rio de Janeiro, were collected respectively in Cambessedesia wurdackii (Melastomataceae) and Bauhinia forficata (Fabaceae). This is the largest species of Megalopta, with some females reaching almost $20 \mathrm{~cm}$ in body length, but many specimens exhibit smaller body size. These smaller specimens may be the result of parasitism by Fiebrigella spp. (Diptera: Chloropidae), whose larvae consume pollen of brood cells and are known to reduce the body size of adult Megalopta bees (Smith et al. 2008). Information on nests of this species was published by Sakagami and Moure (1967). Furthermore, specimens have been attracted by eugenol and methyl salicilate.

The present synonymy is based on the morphology of both sexes; many characters exhibit intraspecific variation, such as the shape of the labral elevation, length of metapostnotum, tergal punctation and body size. Some individuals show purple tints in the basal area of metapostnotum adjacent to the rugulosities.

\section{Distribution}

BOLIVIA. Cochabamba: Villa Tunari. La Paz: Mapiri. BRAZIL. Acre: Acrelândia, Cruzeiro do Sul, Porto Acre, Rio Branco. Amapá: Pedra Branca do Amapari. Amazonas: Barcelos, Beruri, Fonte Boa, Humaitá, Itacoatiara, Japurá, Lábrea, Manaus, Novo Airão, Novo Aripuanã, Presidente Figueiredo, Tabatinga. Bahia: Camacan, Encruzilhada, Lençois, Mucugê, Salvador, Santa Terezinha. Espiríto Santo: Conçeição da Barra, Guarapari, Linhares, Santa Leopoldina. Goiás: Caldas Novas, Colinas do Sul, Jataí. Maranhão: Buriticupu. Mato Grosso: Aripuanã, Chapada dos Guimarães, Nova Lacerda, Nova Mutum, Nova Xavantina, Campo Novo do Parecis. Minas Gerais: Belo Horizonte, Bom Jesus do Amparo, Caratinga, Ipanema, Nova Lima, Santana do Riacho, Três Marias, Uberlândia, Viçosa. Pará: Alenquer, Belém, Belterra, Benevides, Bujaru, Capitão Poço, Itaituba, Melgaço, Ourém, Parauapebas, Peixe Boi, São Miguel do Guama, Tome-Açu, Tucuruí. Paraíba: Mamanguape. Paraná: Antonina, Morretes, São José dos Pinhais. Pernambuco: Caruaru, Jaqueira. Rio de Janeiro: Angra dos Reis, Arraial do Cabo, Cachoeiras de Macacu, Itatiaia, Macaé, Maricá, Teresopólis. Rondônia: Ariquemes, Guajará-Mirim, Itapuã do Oeste, Ouro Preto do Oeste, Porto Velho, Vilhena. Roraima: Amajari, Pacaraima. Santa Catarina: Brusque, Joinville. São Paulo: Caraguatatuba, Juquiá, Itu, Macaubal, Miracatu, Ribeirão Grande, Sete Barras. ECUADOR. Sucumbios: Limoncocha. PERU. Cuzco: Espinar, La Convención, Quincemil, Urabamba. Junin: Chanchamayo. Huánuco: Leoncio Prado, Puerto Inca. Lima: Cañete. Loreto: Mariscal Ramón Castilla, Maynas. Madre de Dios: Mazuko, Santa Rosa, Tambopata. Pasco: Oxapampa. Puno: Carabaya. San Martin: San Martin. SURINAME. Brokopondo: Brokopondo. Nickerie: Wageningen. Paramaribo: Paramaribo. Saramacca: Calcutta. Sipaliwini: Kabalebo. VENEZUELA. Amazonas: Puerto Ayacucho (Figure 16C). 


\section{Acknowledgements}

We thank the numerous collectors of Megalopta referenced herein for specimens collected over the years and for indirectly making possible this study. We also thank all the curators and their institutions for making available material under their care. LMS thanks Fernando A. Silveira for encouraging the study of the taxonomy of Megalopta during the undergraduate studies. We also thank Fernando Silveira and Claudio J.B. Carvalho for making many suggestions to previous version of this publication; Antonio J.C. Aguiar and Rodrigo B. Gonçalves for separating the material deposited in MPEG and MZUSP respectively; Felipe Vivallo for checking the types deposited in BMNH; Vitor Nardino (Taxon Line) for taking photographs; Kevin A. Williams for help with grammar in the manuscript; and Rui C. Peruquetti, Victor H. Gonzalez, Terry Griswold, Ricardo Ayala, William T. Wcislo, Simon M. Tieney and I.C. (Kees) van Achterberg for donating specimens to the DZUP collection. We thank David Notton (BMNH), Jerome Rozen and (AMNH) and Luca Picciau (MSNT) for providing photographs of type material. Anthropologist Pedro R.A. Castro, 'Fundação Nacional do Índio (FUNAI)', is also thanked for providing information on Brazilian indigenous peoples. Finally, we thank 'Conselho Nacional de Pesquisa e Desenvolvimento Tecnológico (CNPq)' for providing the Master's Degree Fellowship (process no. 130687/2008-1) to the first author and a research scholarship to the second author.

\section{References}

Albert B. 1999. Yanomami. Instituto Socioambiental, Povos Indígenas no Brasil [Internet]. [cited 2013 Apr 11]. Available from: http://pib.socioambiental.org/en/povo/yanomami/ print

Almeida RFT, Mura F. 2003. Guarani-Kaiowá. Instituto Socioambiental, Povos Indígenas no Brasil [Internet]. [cited 2013 Apr 11]. Available from: http://pib.socioambiental.org/en/ povo/guarani-kaiowa/print.

Amoroso M. 2009. Mura. Instituto Socioambiental, Povos Indígenas no Brasil [Internet]. [cited 2013 Apr 11]. Available from: http://pib.socioambiental.org/pt/povo/mura/print.

Baird E, Kreiss E, Wcislo WT, Warrant EJ, Dacke M. 2011. Nocturnal insects use optic flow for flight control. Biol Lett. 7:499-501.

Berry RP, Wcislo WT, Warrant EJ. 2011. Ocellar adaptations for dim light vision in a nocturnal bee. J Exp Biol. 214:1283-1293. doi:10.1242/jeb.050427

Biani NB, Wcislo WT. 2007. Notes on the reproductive morphology of the parasitic bee Megalopta byroni (Hymenoptera: Halictidae), and a tentative new host record. J Kans Entomol Soc. 80:392-394.

Brothers DJ. 1976. Modifications of the metapostnotum and origin of the 'propodeal triangle' in Hymenoptera Aculeata. Syst Entomol. 1:177-182. doi:10.1111/j.1365-3113.1976. tb00036.x

Cesar AC. 1988. Inéditos e dispersos. 3rd ed. São Paulo, Brazil: Editora Ática.

Cockerell TDA. 1900. Descriptions of new bees collected by Mr. H. H. Smith in Brazil. -I. Proc Acad Nat Sci Phila. 52:356-377.

Cockerell TDA. 1923. Two nocturnal bees and a minute Perdita. Am Mus Novit. 66:1-4.

Danforth BN, Brady SG, Sipes SD, Pearson A. 2004. Single-copy nuclear genes recover Cretaceous-age divergences in bees. Syst Biol. 53:309-326. doi:10.1080/ 10635150490423737

Danforth BN, Eickwort GC. 1997. The evolution of social behaviour in the augochlorine sweat bees (Hymenoptera: Halictidae) based on a phylogenetic analysis of the genera. In: Choe, JC, Crespi, BJ, editors. The evolution of social behaviour in insects and arachnids. Cambridge (UK): Cambridge University Press; p. 270-292. 
Ducke A. 1908. Contributions a la connaissance des Hymenopteres des deux Amériques. Rev Entomol. 27:28-55.

Ducke A. 1910. Contribution a la connaissance de la faune hyménoptérologique du Nord-Est du Brésil. Rev Entomol. 28:78-96.

Eickwort GC. 1969. A comparative morphological study and generic revision of the augochlorine bees (Hymenoptera: Halictidae). Univ Kansas Sci Bull. 48:325-524.

Engel MS. 2000. Classification of the bee tribe Augochlorini (Hymenoptera: Halictidae). Bull Am Mus Nat Hist. 250:1-89. doi:10.1206/0003-0090(2000)250<0001:COTBTA>2.0.CO;2

Engel MS. 2006. A new nocturnal bee of the genus Megalopta, with notes on the other Central American species (Hymenoptera: Halictidae). Mitt Int Entomol Ver. 31:37-49.

Engel MS. 2011. Noctoraptor in Bolivia (Hymenoptera: Halictidae). J Kans Entomol Soc. 84:64-70. doi:10.2317/JKES101006.1

Engel MS, Brooks RW, Yanega D. 1997. New genera and subgenera of augochlorine bees (Hymenoptera: Halictidae). Sci Pap Nat Hist Mus Univ Kansas. 5:1-21.

Friese H. 1911. Neue Bienen aus Süd-Amerika (Hym.). Dtsch Entomol Z. 1911:453-456.

Friese H. 1923. Wissenschaftliche Ergebnisse der schwedischen entomologischen Reise des Herrn Dr. A. Roman in Amazonas 1914-15. 8. Apidae. Ark Zool. 15:1-8.

Friese H. 1926. Die Nachtbienen-Gattung Megalopta Sm. Stett Entomol Ztg. 87:111-135.

Gonçalves MA. 2000. Pirahã. Instituto Socioambiental, Povos Indígenas no Brasil [Internet]. [cited 2013 Apr 11]. Available from: http://pib.socioambiental.org/en/povo/piraha/print/

Gonzalez VH, Griswold T, Ayala R. 2010. Two new species of nocturnal bees of the genus Megalopta (Hymenoptera: Halictidae) with keys to species. Rev Biol Trop. 58:255-263.

Graham L. 2008. Xavante. Instituto Socioambiental, Povos Indígenas no Brasil [Internet]. [cited 2013 Apr 11]. Available from: http://pib.socioambiental.org/en/povo/xavante/print/

Greiner B, Ribi WA, Warrant EJ. 2004a. Retinal and optical adaptations for nocturnal vision in the halictid bee Megalopta genalis. Cell Tissue Res. 316:377-390. doi:10.1007/s00441004-0883-9

Greiner B, Ribi WA, Warrant EJ. 2004b. Neural organisation in the first optic ganglion of the nocturnal bee Megalopta genalis. Cell Tissue Res. 318:429-437. doi:10.1007/s00441-0040945-Z

Greiner B, Ribi WA, Warrant EJ. 2005. A neural network to improve dim-light vision? Dendritic fields of first-order interneurons in the nocturnal bee Megalopta genalis. Cell Tissue Res. 322:313-320. doi:10.1007/s00441-005-0034-y

Hinojosa-Diaz IA, Engel MS. 2003. Megalopta (Noctoraptor) furunculosa sp. n., a new nocturnal, cleptoparasitic bee from Guyana (Hymenoptera: Halictidae). Folia Heyrovskyana. 11:137-141.

Hopkins MJG, Hopkins HCF, Sothers CA. 2000. Nocturnal pollination of Parkia velutina by Megalopta bees in Amazonia and its possible significance in the evolution of chiropterophily. J Trop Ecol. 16:733-746. doi:10.1017/S0266467400001681

Janzen DH. 1968. Notes on nesting and foraging behaviour of Megalopta (Hymenoptera: Halictidae) in Costa Rica. J Kans Entomol Soc. 41:342-350.

Kapheim KM, Bernal SP, Smith AR, Nonacs P, Wcislo WT. 2011. Support for maternal manipulation of developmental nutrition in a facultatively eusocial bee, Megalopta genalis (Halictidae). Behav Ecol Sociobiol. 65:1179-1190. doi:10.1007/s00265-010-1131-9

Kelber A, Warrant EJ, Pfaff M, Wallén R, Theobald JC, Wcislo WT, Ragusoc RA. 2006. Light intensity limits foraging activity in nocturnal and crepuscular bees. Behav Ecol. 17:63-72. doi:10.1093/beheco/arj001

Knoll FR, Santos LM. 2012. Orchid bee baits attracting bees of the genus Megalopta (Hymenoptera, Halictidae) in Bauru region, São Paulo, Brazil: abundance, seasonality, and the importance of odors for dim-light bees. Rev Bras Entomol. 56:481-488. doi:10.1590/S0085-56262012000400013 
Meade-Waldo G. 1916. LIII.-Notes on the Apidx (Hymenoptera) in the collection of the British Museum, with descriptions of new species. Ann Mag Nat Hist. 17:448-470. doi:10.1080/00222931608693811

Michener CD. 2000. The bees of the world. Baltimore (MD): Johns Hopkins.

Michener CD. 2007. The bees of the world. Baltimore (MD): Johns Hopkins.

Michener CD, Moure JS. 1964. Megalopta Smith, 1853 (Insecta, Hymenoptera): proposed designation of a type-species under the plenary powers. Bull Zool Nomencl. 21:148-149.

Moure JS. 1943. Notas sobre as abelhas da coleção Zikán (Hym: Apoidea). Rev Entomol. $14: 447-484$.

Moure JS. 1958. On the species of Megalopta described by F. Smith (Hymenoptera: Apoidea). J N Y Entomol Soc. 66:179-190.

Moure JS. 2007. Augochlorini Beebe, 1925. In: Moure, JS, Urban, D, Melo, GAR, editors. Catalogue of Bees (Hymenoptera, Apoidea) in the Neotropical Region. Curitiba, Brasil: Sociedade Brasileira de Entomologia; p. 759-823.

Moure JS, Hurd PD. 1987. An annotated catalog of the halictid bees of the Western Hemisphere (Hymenoptera: Halictidae). Washington (DC): Smithsonian Institution Press.

Ramos A. 2003. Munduruku. Instituto Socioambiental, Povos Indígenas no Brasil [Internet]. [cited 2013 Apr 11]. Available from: http://pib.socioambiental.org/en/povo/munduruku/print/

Sakagami SF, Moure JS. 1965. Cephalic polymorphism in some neotropical halictine bees. An Acad Bras Cienc. 37:303-313.

Sakagami SF, Moure JS. 1967. Additional observations on the nesting habits of some Brazilian halictine bees (Hymenoptera: Apoidea). Mushi. 40:119-137.

Santos LM, Melo GAR. 2013. Taxonomic notes and description of the male of Xenochlora nigrofemorata (Smith, 1879) (Hymenoptera: Apidae: Halictinae). Zootaxa. 3670:371-377. doi:10.11646/zootaxa.3670.3.7

Santos LM, Silveira FA. 2009. Taxonomic notes on Megalopta Smith, 1853 (Hymenoptera: Halictidae: Augochlorini) with a synopsis of the species in the state of Minas Gerais, Brazil. Zootaxa. 2194:1-20.

Santos LM, Tierney SM, Wcislo WT. 2010. Nest descriptions of Megalopta aegis (Vachal) and M. guimaraesi Santos \& Silveira (Hymenoptera, Halictidae) from the Brazilian Cerrado. Rev Bras Entomol. 54:332-334. doi:10.1590/S0085-56262010000200018

Schrottky C. 1906. Neue und wenig bekannte südamerikanische Bienen. Z Syst Hymenopterol Dipterol. 6:305-316.

Smith AR, Wcislo WT, O'Donnell S. 2008. Body size shapes caste expression, and cleptoparasitism reduces body size in the facultatively eusocial bees Megalopta (Hymenoptera: Halictidae). J Insect Behav. 21:394-406. doi:10.1007/s10905-008-9136-1

Smith F. 1853. Catalogue of hymenopterous insects in the collection of the British museum, Part 1: Andrenidae and Apidae. London (UK): Taylor \& Francis.

Smith F. 1879. Descriptions of new species of Hymenoptera in the collection of the British museum. London (UK): Taylor \& Francis.

Spinola M. 1853. Compte rendu des Hyménopteres inédits provenants du voyage entomologique de M. Ghiliani dans le Para en 1846. Mem R Accad Sci Torino. 2:19-94.

Storto L, Velden FFV. 2005. Karitiana. Instituto Socioambiental, Povos Indígenas no Brasil [Internet]. [cited 2013 Aug 14]. Available from: http://pib.socioambiental.org/en/povo/ karitiana/print

Tierney SM, Gonzales-Ojeda T, Wcislo WT. 2008. Biology of a nocturnal bee, Megalopta atra (Hymenoptera: Halictidae; Augochlorini), from the Panamanian highlands. J Nat Hist. 42:1841-1847. doi:10.1080/00222930802109124

Tierney SM, Sanjur O, Grajales GG, Santos LM, Bermingham E, Wcislo WT. 2012. Photic niche invasions: phylogenetic history of the dim-light foraging augochlorine bees (Halictidae). Proc R Soc Lond B Biol Sci. 279:794-803.

Vachal J. 1904. Étude sur les Halictus d'Amerique (Hym.). Misc Entomol. 12:113-115. 
Warrant EJ, Kelber A, Gislén A, Greiner B, Ribi W, Wcislo WT. 2004. Nocturnal vision and landmark orientation in a tropical halictid bee. Curr Biol. 14:1309-1318. doi:10.1016/j. cub.2004.07.057

Wcislo WT, Arneson L, Roesch K, Gonzalez VH, Smith A, Fernández H. 2004. The evolution of nocturnal behaviour in sweat bees, Megalopta genalis and M. ecuadoria (Hymenoptera: Halictidae): an escape from competitors and enemies? Biol J Linn Soc Lond. 83:377-387. doi:10.1111/j.1095-8312.2004.00399.x

Wcislo WT, Gonzalez VH. 2006. Social and ecological contexts of trophallaxis in facultatively social sweat bees, Megalopta genalis and M. ecuadoria (Hymenoptera, Halictidae). Insect Soc. 53:220-225. doi:10.1007/s00040-005-0861-6

Wcislo WT, Tierney SM. 2009. Behavioural environments and niche construction: the evolution of dim-light foraging in bees. Biol Rev Camb Philos Soc. 84:19-37. doi:10.1111/ j.1469-185X.2008.00059.x

\section{Appendix 1. Checklist and notes on valid species of Megalopta}

Megalopta aegis (Vachal, 1904) [aegis group]

Halictus aegis Vachal, 1904: 115. Lectotype male, designated by Moure \& Hurd (1987: 235), Brazil: Goiás, Jataí (MNHP, not examined).

Megalopta aeneicollis Friese, 1926 [aegis group]

Megalopta aeneicollis Friese, 1926: 119, 122, 132. Lectotype female, designated by Santos \& Silveira (2009:16), Brazil: Amazonas, Barcelos (ZMB, examined).

Megalopta amoena (Spinola, 1853) [amoena group]

Halictus amoenus Spinola, 1853: 85. Holotype male, Brazil: Pará (MSNT, examined through photographs)

Megalopta idalia Smith, 1853: 84. Syntypes, Brazil: Amazonas and Pará, Santarém (BMNH, not examined).

Halictus argoides Vachal, 1904:115. Holotype male, Guiana (MNHP, not examined).

Megalopta ochrias Vachal, 1904:115. Holotype male, Brazil: Goiás, Jataí (MNHP, examined).

Megalopta ecuadoria Friese, 1926: 127. Lectotype female, designated by Engel (2006:43), Ecuador: Guayas, Guayaquil (ZMB, examined).

Megalopta centralis Friese, 1926: 128. Lectotype male, designated by Engel (2006:43) Guatemala (ZMB, examined).

Megalopta gibbosa Friese, 1926:128. Holotype male, Ecuador: Guayas, Guayaquil (ZMB, examined). New synonymy.

Megalopta lecointei Friese, 1926:122. Lectotype female, presently designated (see above), Brazil: Pará, Óbidos (ZMB, examined). New synonymy.

Megalopta vigilans Cockerell, 1923:1. Holotype male, uncertain type locality (AMNH, examined through photographs). New synonymy.

Megalopta armata Friese, 1926 [sodalis group]

Megalopta armata Friese 1926: 132. Lectotype female, designated by Santos \& Silveira (2009:16), Ecuador: Guayas, Guayaquil (ZMB, examined). 


\section{Comments}

It is possible that this species is a junior synonym of $M$. sodalis.

Megalopta atlantica Santos \& Silveira, 2009 [byroni group]

Megalopta atlantica Santos \& Silveira, 2009:14. Holotype male, Brazil: Minas Gerais, Ipanema (DZUP, examined).

Megalopta atra Engel, 2006 [atra group]

Megalopta atra Engel, 2006: 115. Holotype female, Panama: Chiriquí, Fortuna Research Station, 1200m (SEMK, not examined).

'Megalopta diurnalis' Kelber et al. (2006: 67, 68, 69) [nomen nudum].

\section{Comments}

Two specimens of Megalopta atra were examined in the collection of David Roubik in STRI, with the following labels: 'Museum Leiden, N. Panama, 1050m, \Fortuna Chiriqui, 844'N 82¹5'W, 07-13/02/1978\ H. Wolda, at light' ' $M$. diurnalis $\backslash$ Brooks \& Engel' (1 9 , STRI); 'Museum Leiden, North Panama, 1050m, $\backslash$ Fortuna Chiriqui, $8^{\circ}$ $44^{\prime} \mathrm{N} 82^{\circ} 15^{\prime} \mathrm{W}, \backslash$ 09-16/02/1977\ H. Wolda, at light' M. diurnalis $\backslash$ Brooks \& Engel' (1ㅇ, STRI).

Megalopta boliviensis Friese, 1926 [sodalis group]

Megalopta boliviensis Friese, 1926: 131. Lectotype female, designated by Santos \& Silveira (2009:16), Bolivia: La Paz, Mapiri (ZMB, examined).

\section{Comments}

This species is most similar to $M$. sodalis, but differs from that species mainly in the bluish integumental color. Synonymy here would be premature without examining more material from Bolivia.

Megalopta byroni Engel, Brooks \& Yanega, 1997 [byroni group] Megalopta byroni Engel, Brooks \& Yanega, 1997: 12. Holotype female, Panama: Panama, Barro Colorado Island (SEMK, not examined).

Megalopta chaperi (Vachal, 1904) [amoena group]

Halictus chaperi Vachal, 1904: 113. Holotype female, Venezuela (MNHP, not examined).

Megalopta cuprea Friese, 1911 [sodalis group]

Megalopta cuprea Friese, 1911: 453. Lectotype female, designated by Santos \& Silveira (2009:16), Bolivia: La Paz, Mapiri (ZMB, examined). 
Megalopta furunculosa Hinojosa-Díaz \& Engel, 2003 [byroni group]

Megalopta furunculosa Hinojosa-Díaz \& Engel, 2003: 137. Holotype female,

Guyana: Iwokrama Forest, 26 km SW Kurupukari (SEMK, not examined).

Megalopta genalis Meade-Waldo, 1916 [sodalis group]

Megalopta genalis Meade-Waldo, 1916: 452,453. Holotype female, Panama: Bugaba (BMNH, not examined).

Megalopta guarani sp. n. Santos \& Melo [byroni group]

Megalopta guimaraesi Santos \& Silveira, 2009 [amoena group]

Megalopta guimaraesi Santos \& Silveira, 2009: 10. Holotype female, Brasil:

Minas Gerais, Jabouticatubas, 'Serra do Cipó' (DZMG, examined).

Megalopta huaoranii Gonzalez, Griswold and Ayala, 2010 [byroni group]

Megalopta huaoranii Gonzalez, Griswold \& Ayala, 2010: 260. Holotype female, Ecuador: Napo, 'Yasuni Res.' (BLCU, not examined).

Megalopta karitiana sp. n. Santos \& Melo [byroni group]

Megalopta mapinguari sp. n. Santos \& Melo [byroni group]

Megalopta mura sp. n. Santos \& Melo [amoena group]

Megalopta munduruku sp. n. Santos \& Melo [sodalis group]

Megalopta nigriventris Friese, 1926 [amoena group]

Megalopta nigriventris Friese, 1926: 119, 121, 129. Holotype female, French Guiana: 'Nouveau Chantier, Bas Maroni' (ZMB, examined).

Megalopta nitidicollis Friese, 1926 [aegis group]

Megalopta nitidicollis Friese, 1926: 121, 122, 130. Lectotype female, presently designated (see above), Bolivia: Cochabamba, Tarata (ZMB, examined).

Megalopta noctifurax Engel, Brooks \& Yanega, 1997 [byroni group]

Megalopta noctifurax Engel, Brooks \& Yanega, 1997: 14. Holotype female, Ecuador: Napo, Coca (CUIC, not examined).

Megalopta notiocleptis Engel, 2011 [byroni group]

Megalopta notiocleptis Engel, 2011: 67. Holotype female, Bolivia: Cochabamba, 'Cristal Mayu' (SNCBSH, not examined).

Megalopta peruana Friese, 1926 [sodalis group]

Megalopta peruana Friese, 1926:121, 131. Holotype female, Peru (ZMB, examined). 


\section{Comments}

It is possible that this species is a junior synonym of $M$. sodalis.

Megalopta piraha sp. n. Santos \& Melo [yanomami group]

Megalopta purpurata Smith, 1879 [byroni group]

Megalopta purpurata Smith, 1879: 48. Holotype male, Brazil: Amazonas, Tefé (BMNH, examined through photographs).

Megalopta sodalis (Vachal, 1904) [sodalis group]

Halictus sodalis Vachal, 1904: 114. Holotype female, Brazil: Santa Catarina, Joinville (MNHP, not examined).

Halictus fornix Vachal, 1904: 114. Holotype female, Peru: 'Huallaga' (MNHP, not examined). New synonymy.

Halictus aethautis Vachal, 1904:115. Holotype male, Peru: Lima, Callanga (MNHP, not examined).

Megalopta sulciventris Friese, 1926 [aegis group]

Megalopta sulciventris Friese, 1926: 129. Lectotype female, designated by Santos \& Silveira (2009:16), French Guiana: 'Nouveau Chantier, Bas Maroni' (ZMB, examined).

Megalopta tacarunensis Cockerell, 1923 [sodalis group]

Megalopta tacarunensis Cockerell, 1923: 444. Holotype male, Guyana: 'Cattle Trail Survey, Takaruni R. (sec. 2)' (BMNH, not examined).

Megalopta tetewana Gonzalez, Griswold \& Ayala, 2010 [amoena group] Megalopta tetewana Gonzalez, Griswold \& Ayala, 2010: 256. Holotype female, Mexico: Jalisco, Chamela (BLCU, not examined).

\section{Comments}

It is possible that this species is an additional junior synonym of $M$. amoena.

Megalopta xavante sp. n. Santos \& Melo [byroni group]

Megalopta yanomami sp. n. Santos \& Melo [yanomami group]

\section{APPENDIX 2. Data label of additional material examined}

\section{Megalopta aegis}

BRAZIL: Alagoas: 'BRASIL:AL $\backslash$ Ibateguara, 400m\10-20.iii.1994\ V.O. Becker col.'

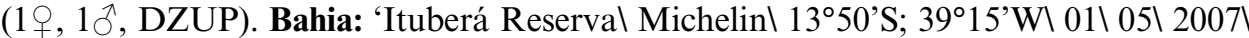
Equipe Ecopol Leg' (19, UFBA). Ceará: 'Cearál Maranguape\14-9-1908\Ducke' 'Brazill Estado dol Ceará' (1ㅇ, DZUP). Distrito Federal: 'BRASIL, DF, Brasília,

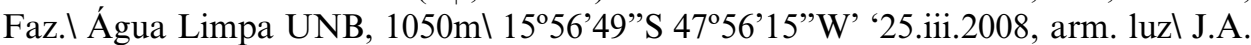


Rafael, F.F. Xavier $\mathrm{F}^{\circ}$ '(19, INPA); 'Coleçãol EMBRAPA-CPACl No10536' 'Planaltina, DF $\backslash$ BRASIL - 1000m $\backslash 25 . i x .1985 \backslash$ V.O. Becker col. $\backslash 15^{\circ} 35^{\prime}$ S $\backslash 47^{\circ} 42^{\prime} W^{\prime}$ ' (169, DZUP); 'Planaltina, DF\ BRASIL - 1000m\18.ix.1984 \V.O. Becker col.। $15^{\circ} 35^{\prime} \mathrm{S} \backslash 47^{\circ} 42^{\prime} \mathrm{W}^{\prime}$ ( 2 + , DZUP); 'Planaltina, DF $\backslash$ BRASIL - 1000m $\backslash 22.1 i .1985 \backslash$ V.O. Becker col. $\backslash 15^{\circ} 35^{\prime} S \backslash 47^{\circ} 42^{\prime} W^{\prime}$ ' (1 9 , DZUP); 'Coleção EMBRAPA-CPAC N $^{\circ} 10679^{\prime}$ ' 'Planaltina, DF $\backslash$ BRASIL - 1000m\3.viii.1986 \V.O. Becker col. $\backslash 15^{\circ} 35^{\prime} \mathrm{S} \backslash 47^{\circ} 42^{\prime} \mathrm{W}$ ' (5ㅇ, 1ð, DZUP); 'BRASIL:DF,\Brasília, 1000m \15.IX.1984\ V.O. Becker col.। (2q, DZUP). Espírito Santo: 'Brasil, ES, Linhares,\ Res. Vale Rio Doce, \sede $56 \mathrm{~m} \backslash$ 1909’05”S 4004'10’W, 07.v.2007, J. Rafael \&\ F. Xavier Fo, luz' (19, DZUP); 'Brasil, ES, Linhares\19.XI.1990' (3ㅇ, DZUP); 'Ribeiro do Enganol Espírito Santol C.I.O. Cruz 10-40' (19, DZUP); 'Rib. do Engano E.S.I Vale do Itaunal Trav. E Santos-9-10-42' (1ㅇ, DZUP). Goiás: 'BRASIL: GO\Alto Paraíso\1100m 4.x.1985 V.O. Becker col' (5, DZUP); '13079-38790' '21h-22h' 'Caldas Novas GO\BRASIL 19/10/2006 S.C. Augusto' (19, DZMG); '13079-38791' '21h-22h' 'Caldas Novas GO। BRASIL 19/10/2006\ S.C. Augusto' (19, DZMG); '13079-38792' 18h-45-19h-45।

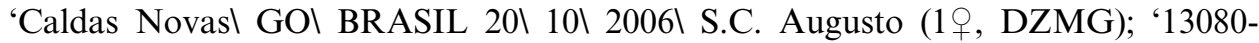

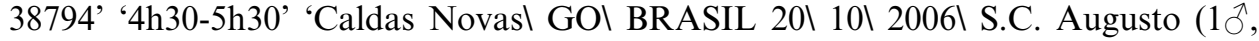
DZMG); 'Brasil, GO, Caldas $\backslash$ Novas Parque Est. Serra de Caldas Novas, $1.000 \mathrm{~m}$ '

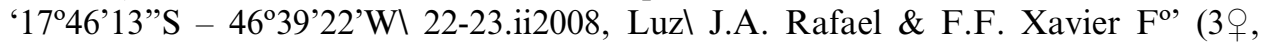

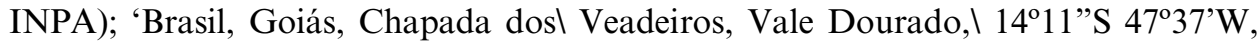
1100m, \01.iv.2003, 6h, Melo, Aguiar, \Marchi e Gonçalves (1 9 , DZUP); 'Formosa, Goiás\BRASIL - 800m\22.IX.1984\ V.O. Becker' (19, DZUP); 'BRASIL: GO। Goiás, Cor\ Paciência\A. Raw col\12.10.1984 (19, DZUP);'Faz. Nova Orlândial Jataí, GO-Brasil\ I.1964-Martins,\ Morgante \& Silva.' 'À luz' (1ㅇ, MZUSP). Maranhão: '22-x-2001 SERRA DO\ PENITENTE, BALSAS $\backslash$ MA, 500m\C. MIELKE LEG' (4+, DZUP); 'Brasil, Maranhãol Serra do Penitente, \ 01-02. xi.2002, C. Mielke' (3q, 2ð̄, DZUP); 'Brasil (MA), Caxias\ Res. Ecol. Inhamum। Armadilha Luminosa' '03-05.viii.2005,। F. Limeira-de-Oliveiral et al cols.' (6옹, INPA); 'Brasil (MA), Caxias\ Riac. Fazenda Nova\ Armadilha Luminosal 25-26.

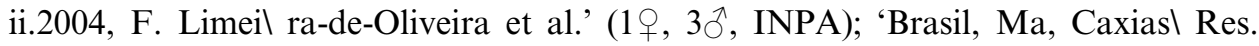
Ecol. Inhamum\ Lenço e luz mista 01-03.ix.2005 F. Limeira- $\backslash$ de-Oliveira et al' (3ㅇ, INPA); 'Brasil (MA), Mirador $\backslash$ Parque Est. Mirador $\backslash$ Base da Geraldina' Arma. Luminosa\20-24.xiii.2006, R.O.I Souza; J.C. Silva et al' (1+, INPA); 'Brasil, Maranhão, Urbanol Santos $3^{\circ} 14^{\prime}$ S 432' W.I 20.x.2009, C.M. Maia leg'. (2ㅇ, INPA). Mato Grosso: 'Barra do Tapirapél Mato Grosso - Brasil X XI. 1964\ B. Malkin col.' (3q, MZUSP); 'Chapada dos\ Guimarães (Buriti)\ MT BRASIL X.1972 G.R. Kloss \& F. Val' (1q, MZUSP); 'BRASIL: MT $\backslash$ Chapadal Guimarães\25.v.1989\VO Becker' (1つ̂, DZUP); 'BRASIL MT Noval Mutum

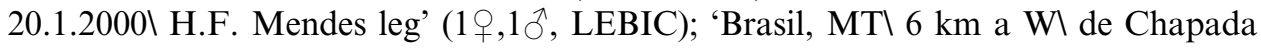
dos Guimarães, $770 \mathrm{~m} \backslash 15.452^{\circ} \mathrm{S} 55.806^{\circ} \mathrm{W}, \backslash$ 8.ix.2012, Cavichioli, Melo, Rosa \& Santos' 'Armadilhal Luminosa' (1q, 11§̂, DZUP); 'Jacaré - P.N. Xingu। MT Brasil XI.1961\Alvarenga, Werrer' (1̋̂, DZUP); 'Rio Caraguatál Mato Grossol Brazil III 1953\F. Plaumann' (1ڤึ, DZUP); 'Utiariti\ Rio Papagaio, Mt\ 1-12. XI.1966\ Lenko \& Pereira' (1q, MZUSP); 'Alto Xingu\ M. Grosso P. Leonardo Agostol R. Arlé Col. 1963' (19, MPEG). Mato Grosso do Sul: 'BRASIL:MS। Corumbá, $600 \mathrm{~m} \backslash 20-22 . i v .1985 \backslash$ V.O. Becker col.' (1ㅇ, DZUP); 'Brasil, Mato Grosso do $\backslash$ Sul, $20 \mathrm{Km}$ ao norte del Rio Verde, 7.ix.2003\ Mielke \& Casagrande' (19, DZUP); 'Serra do Urucum\Corumbá - Mato Grossol Brasil 5.XII.1960\K. 
Lenko col.’ (1ð̂, DZUP). Minas Gerais: '29-i-3-ii-2003 ESTAÇÃO\BIOLÓGICA DE CARATINGA,\CARATINGA, MG, 400m\ MIELKE \& CASAGRANDE LEG.' (1ㅇ, DZUP); 'Brasil, Minas Gerais, $13 \mathrm{Km}, \backslash \mathrm{NE}$ de Ipanema, Fazendal Montes Claros, 400m\29.-i-30.i.2003 Mielke \&l Casagande, armadilhal luminosa' (69, DZUP); '9-III 1994. Pq. Est.। Rio Doce, 350m\ Marliéria, M.G.। O. Mielke leg.' (19, DZUP). 'Entomofauna dol Pq. E. Rio Docel 12765-37291' 'Marliéria MG। BRASIL 13/01/1978\ D' Andretta e Perreira' (19, DZMG); 'Entomofauna do\ Pq. E. Rio Docel 12765-37292' 'Marliéria MG\ BRASIL 13/01/1978\ D' Andretta e Perreira' (1q, DZMG); 'Entomofauna dol Pq. E. Rio Docel 12767-37327' 'Marliéria MGI BRASIL 08/03/1978\ D' Andretta e Perreira' (19, DZMG); 'Entomofauna dol Pq. E. Rio Docel 12771-37549' 'Marliéria MG\BRASIL 08/07/ $1978 \backslash$ D' Andretta e Monteiro' (1, DZMG); 'Entomofauna dol Pq. E. Rio Docel 12771-37546' 'Marliéria MG\ BRASIL 08/07/1978\ D' Andretta e Monteiro' (1 9 , DZMG); 'Entomofauna do $\$ Pq. E. Rio Docel 12771-37550' 'Marliéria MG\ BRASIL 08/07/1978\ D' Andretta e Monteiro' (19, DZMG); 'Entomofauna dol Pq. E. Rio Doce\ 12771-37551' 'Marliéria MG\BRASIL 08/07/1978\ D' Andretta e Monteiro' (19, DZMG); 'Entomofauna dol Pq. E. Rio Docel 12771-37552' 'Marliéria MG। BRASIL 08/07/1978\ D' Andretta e Monteiro' (19, DZMG); 'Entomofauna do\ Pq. E. Rio Docel 12771-37562' 'Marliéria MG\BRASIL 08/07/1978\ D' Andretta e Monteiro' (19, DZMG); 'Entomofauna dol Pq. E. Rio Docel 12775-37628' 'Marliéria MG\ BRASIL 01/12/1978\ D' Andretta e Monteiro' (19, DZMG); 'Entomofauna do\ Pq. E. Rio Docel 12787-37701' 'Marliéria MG\BRASIL 22/07/ 1980\ D' Andretta e Monteiro' (1+, DZMG); 'Entomofauna dol Pq. E. Rio Docel

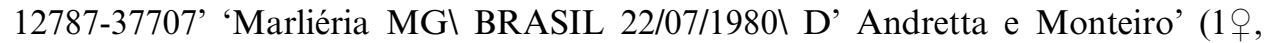
DZMG); 'Entomofauna do $\$ Pq. E. Rio Docel 12787-37708' 'Marliéria MG\BRASIL 22/07/1980\ D' Andretta e Monteiro' (1q, DZMG); 'Entomofauna dol Pq. E. Rio Doce $12787-37709$ ' 'Marliéria MG\BRASIL 22/07/1980\ D' Andretta e Monteiro' (19, DZMG); 'Entomofauna dol Pq. E. Rio Docel 12787-37715' 'Marliéria MG। BRASIL 22/07/1980\ D' Andretta e Monteiro' (19, DZMG); 'Entomofauna dol Pq. E. Rio Docel 12787-37731' 'Marliéria MG\BRASIL 22/07/1980\ D' Andretta e Monteiro' (19, DZMG); 'Entomofauna dol Pq. E. Rio Docel 12787-37737' 'Marliéria MG\BRASIL 22/07/1980 D' Andretta e Monteiro' (1q, DZMG); 'Entomofauna do\ Pq. E. Rio Docel 12758-37234' 'Marliéria MG\BRASIL 20/10/ 1980 Monteiro \& Mascarenhas' (1 9, DZMG); 'Entomofauna dol Pq. E. Rio Docel 12758-37235' 'Marliéria MG\BRASIL 20/10/1980\ Monteiro \& Mascarenhas' (1옹, DZMG); 'Entomofauna do\ Pq. E. Rio Docel 12758-37236' 'Marliéria MG\BRASIL 20/10/1980\ Monteiro \& Mascarenhas' (1q, DZMG); 'Entomofauna do Pq. E. Rio Doce\ 12758-37237' 'Marliéria MG\BRASIL 20/10/1980\ Monteiro \& Mascarenhas' (19, DZMG); 'Entomofauna dol Pq. E. Rio Docel 12758-37238' 'Marliéria MG। BRASIL 20/10/1980\ Monteiro \& Mascarenhas' (19, DZMG); 'Entomofauna dol Pq. E. Rio Docel 12758-37239' 'Marliéria MG\ BRASIL 20/10/1980\ Monteiro \& Mascarenhas' (1ㅇ, DZMG); 'Entomofauna dol Pq. E. Rio Docel 12758-37240' 'Marliéria MG\BRASIL 20/10/1980\ Monteiro \& Mascarenhas' (1q, DZMG); 'Entomofauna do\ Pq. E. Rio Docel 12758-37241' 'Marliéria MG\BRASIL 20/10/ 1980\Monteiro \& Mascarenhas' (1 9, DZMG); 'Entomofauna dol Pq. E. Rio Docel 12758-37242' 'Marliéria MG BRASIL 20/10/1980\ Monteiro \& Mascarenhas' (1, DZMG); 'Entomofauna dol Pq. E. Rio Docel 12758-37243' 'Marliéria MG\BRASIL 20/10/1980 Monteiro \& Mascarenhas' (1q, DZMG); 'Entomofauna do \Pq. E. Rio 
Docel 12758-37244' 'Marliéria MG BRASIL 20/10/1980\ Monteiro \& Mascarenhas' (19, DZMG); 'Entomofauna dol Pq. E. Rio Docel 12787-37707' 'Marliéria MG। BRASIL 22/07/1980\ D' Andretta e Monteiro' (1+, DZMG); '13068-38768' 'São Gonçalo do Rio Abaixo MG\ BRASIL 1/10/2005\ L.M. Santos' (19, DZMG); '13071-38772' 'São Gonçalo do Rio Abaixo MG। BRASIL 28/04/2006। L.M. Santos' (19, DZMG); '13071-38773' 'São Gonçalo do Rio Abaixo MG\ BRASIL 28/04/2006 L.M. Santos' (1 +, DZMG); '13071-38772' 'São Gonçalo do Rio Abaixo MG $\backslash$ BRASIL 28/04/2006 L.M. Santos' (1 + , DZMG); '13072-38778' 'São Gonçalo do Rio Abaixo MG BRASIL 28/04/2006 L.M. Santos' (1 q, DZMG); 'Reinventáriol EPDA de Petil 8814-26549' 'São Gonçalo do Rio Abaixo MG\BRASIL 11/01/2003। C.F. Cardoso' (1q, DZMG); 'Reinventáriol EPDA de Petil 8814-26550' 'São Gonçalo do Rio Abaixo MG\ BRASIL 11/01/2003\ C.F. Cardoso' (19, DZMG); 'Reinventáriol EPDA de Petil 8814-26551' 'São Gonçalo do Rio Abaixo MGl BRASIL 11/01/2003\ C.F. Cardoso' (1 , DZMG); '10286-30097' 'São Gonçalo do Rio Abaixo MG\BRASIL 14/11/2003\ A.F. Kumagai' (1 9, DZMG); '10286-30098' 'São Gonçalo do Rio Abaixo MG\ BRASIL 14/11/2003\ A.F. Kumagai' (1 DZMG); '10286-30099' 'São Gonçalo do Rio Abaixo MG\ BRASIL 14/11/2003। A.F. Kumagai' (1̊, DZMG); '10287-30110' 'São Gonçalo do Rio Abaixo MGl BRASIL 15/11/2003\ A.F. Kumagai' (19, DZMG); '10287-30111' 'São Gonçalo do Rio Abaixo MG\BRASIL 15/11/2003\ A.F. Kumagai' (1 + , DZMG); '10287-30112'

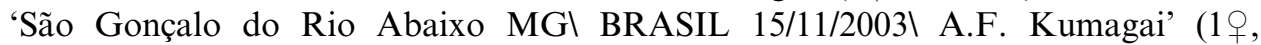

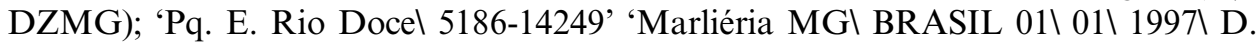
A. Yanega' (19, DZMG); 'Serra do Cipó $5187-14250$ ' 'BRAZIL, Minas Gerais $\backslash$ Est. Ecológica do Peti\ 10-X-1997\ D. Yanega' (19, DZMG); 'Serra do Cipó $5187-14251$ ' 'BRAZIL, Minas Gerais\ Est. Ecológica do Petil 10-X-1997\ D. Yanega' (1ㅇ, DZMG); 'Abelhas Noturnas\ EPDA de Petil CEMIG\ 8434-25751' 'São Gonçalo do Rio Abaixo MG’ BRASIL 30/05/2003\ L.M. Santos' (19, DZMG); 'Abelhas Noturnas $\backslash$ EPDA de Peti $\backslash$ CEMIG $8435-25752$ ' 'São Gonçalo do Rio Abaixo MG’' BRASIL 31/05/2003\ L.M. Santos' (19, DZMG); '13068-38761' 'São Gonçalo do

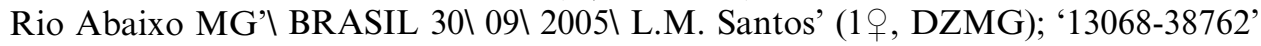

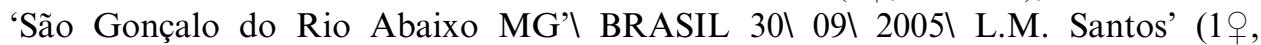
DZMG); '13068-38763' 'São Gonçalo do Rio Abaixo MG’ $\backslash$ BRASIL 30\09\2005\ L.M. Santos' (19, DZMG); '13069-38765' 'São Gonçalo do Rio Abaixo MG’'

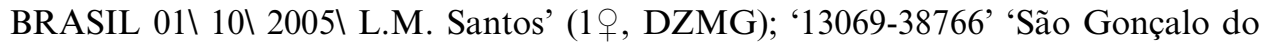

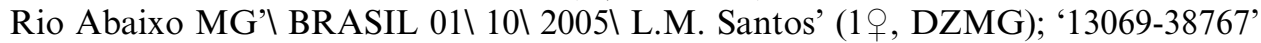
'São Gonçalo do Rio Abaixo MG’ BRASIL 01\10 2005\ L.M. Santos' (1 ,

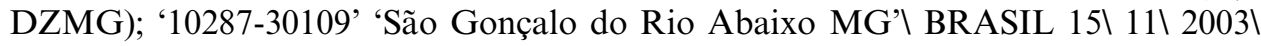
A.F. Kumagai’ (1ㅇ, DZMG). 'S. do Cipó $9093-27157$ ' 'Jaboticatubas MG\BRASIL 07/10/2002\ E. O. Machado' (1 9 , DZMG); 'Curso de campo\ ECMVS/DZMG $\backslash$ Pq. E. Rio Pretol 10888-32170' 'S. Gonçalo do Rio Preto MG\BRASIL 25/09/2003\ L.R. R. Faria Jr' (1 9 , DZMG); 'Curso de campol ECMVS/DZMG\ Pq. E. Rio Pretol 10887-32169' (19, DZMG); 'S. Gonçalo do Rio Preto MG\ BRASIL 17/09/2003\ L. R.R. Faria Jr' (1q, DZMG); 'Pq. E. Rio Pretol 9083-27138' 'São Gonçalo do Rio Preto MG\BRASIL 18/10/2000\ J. A. Lombardi’ (19, DZMG); 'Pq. E. Rio Pretol 9083-27141' 'São Gonçalo do Rio Preto MG\ BRASIL 03/04/2003\J. A. Lombardi' (19, DZMG); 'Pq. E. Rio Pretol 9088-27144' 'São Gonçalo do Rio Preto MGl BRASIL 15/10/2003\F. S. Faria' (1, DZMG); 'Est. Pirapitingal 3042-8974' 'Três Marias MG\BRASIL 01/05/1998\ D. A. Yanega' (19, DZMG); 'Est. Pirapitingal 
3042-8975' 'Três Marias MG\ BRASIL 01/05/1998\ D. A. Yanega' (19, DZMG); 'Serra do Cipó \5187-14252' 'Santana do Riacho MG\BRASIL 12/03/1997\ D. A. Yanega' (19, DZMG); 'Serra do Cipól 5202-14272' 'Santana do Riacho MGl BRASIL 12/03/1997\ D. A. Yanega' (1ㅇ, DZMG); 'Serra do Cipól 5212-14285' 'Santana do Riacho MG BRASIL 12/03/1997 D. A. Yanega' (1q, DZMG); 'Serra do Cipól 5212-14286' 'Santana do Riacho MG\ BRASIL 12/03/1997\ D. A. Yanega' (1+, DZMG); 'Serra do Cipól 5212-14282' 'Santana do Riacho MGl BRASIL 12/03/1997\ D. A. Yanega' (1ㅇ, DZMG); 'Serra do Cipól 5212-14287' 'Santana do Riacho MG BRASIL 12/03/1997\ D. A. Yanega' (1q, DZMG); 'Serra do Cipól 2235-7050' 'Santana do Riacho MG\BRASIL 21/04/1998\ D. A. Yanega' (1 9 , DZMG). Pará: 'Brasil Pará \Alenquer 2 Julho de 1979' 'Brasil Parál W

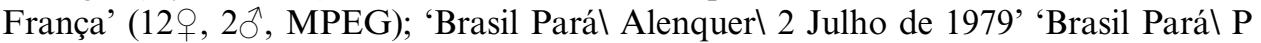
Tadeu' (4+, MPEG); 'BRASIL, PA, Alter dol Chão, Igarapé Sonrisall 18.iv.2008, arm. luzl J.A. Rafael, F.F. Xavier F'.' (2ㅇ, INPA); 'BRASIL, Pará, Belo Monte,l

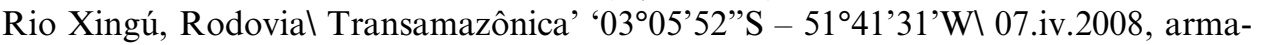
dilha luzl J.A. Rafael \& F.F. Xavier $\mathrm{F}^{\circ}$ ' (1+1, 10,, INPA); 'Brasil, PA, Belterral

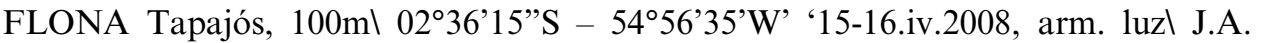
Rafael, F.F. Xaier F' ${ }^{\circ}$ (2ᄋ, 1ð, INPA);'PA Bragançal 27-v-1978' 'Brasil Parál R B

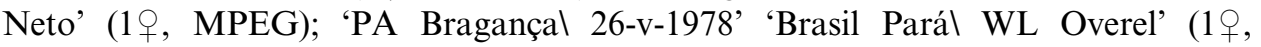
MPEG); 'Brasil Parál Bujarul 15.iv.1978' 'Brasi Paral R B Neto' (7오․ MPEG); 'Pará Bujarul 24-III-1978' 'Brasil Parál N. de Souza' (1올 MPEG); 'Brasil Parál Campus do MPEG\ 17.II.1991' 'Brasil Parál Márcio Zanuto' (1ㅇ․ MPEG); 'BRASIL: PAI Capitão Poçol 28-31.i.1984\ V.O. Becker col' (7오 DZUP); 'BRASIL: PA\ Capitão Poçol 19-22.xi.1984\ V.O. Becker col' (8, DZUP); 'Aldeia Yavaruhu (Igarapé Gurupi-Uma\ 45 Km E Canindé)\ Pará Brasil \XII. 1964. B. Malkin' (1 q, MZUSP); 'OBIDOS \ Pará BRASIL\ Dezembro 1955 F.M. Oliveira' 'COLEÇÃO \CAMPOS SEABRA' (19, DZUP); 'Obidos $\backslash 1904$ ' 'Brazil $\backslash$ Estado dol Pará' (1ㅇ, DZUP); 'OBIDOS $\backslash 1905 \backslash$ P. Lecointe' 'Brazil $\backslash$ Estado do Pará' (1q, DZUP); 'Brasil Pará Ourém\ Faz. Gavião Real\ 20 VIII-1991' 'Brasil Pará Ouréml Patauateua/Faz. Gavião Real\ 30.IV. a 3.V.1992/Arm. Luz Col B. Mascarenhas e eq.' (19, MPEG); 'Brasil Parál Ourém\ Patauateual 19-VIII-1992' 'Brasil Parál B. Mascarenhas' 'Armadilhal de Luz' (5, MPEG); 'Brasil Parál Ourém\ Patauateual 20-VIII-1992' 'Brasil Parál B. Mascarenhas' 'Armadilhal de Luz' (2ᄋ, MPEG); 'Brasil Pará Ourém\ Patauateua/Faz. Gavião Reall 30.IV. a 3.V.1992/Arm. Luzl Col B. Mascarenhas e eq.' (1+, MPEG); 'Brasil Pará Ourém\ Patauateua/Faz. Gavião Real\ 30.IV. a 3.V.1992/Arm. Luzl Col B. Mascarenhas e eq.' (1+, MPEG); 'Brasil Parál Santarém Novol Faz. Jaburul 8.I.1993' 'Brasil Parál J Dias' 'Armadilhal de Luz' (1+, MPEG); 'Brasil Pará São João de Pirabas\Japerica\ Ilha Conceiçãol 20-XII-1992' 'Brasil Parál J. Dias' 'Armadilhal de Luz' (3ㅇ,1ð̂, MPEG); 'Brasil Parál São João de Pirabas\ Japerical Ilha Conceiçãol 22-XII-1992' 'Brasil Parál J. Dias' 'Armadilhal de Luz' (1+10̄, MPEG); 'Brasil Parál São João de Pirabas\ BOA ESPERANÇA\ 26 a 30.X.1989' 'Brasil Parál N. Bittencourt' 'Armadilhal Malayse' (1ڤ̂, MPEG); 'Brasil Parál Serra Nortel Serrarial COL. NOTURNAI 19-X-1984' 'MPEG HYM $\backslash 11005580$ ' (19, MPEG); 'Brasil Parál Serra Nortel Serrarial COL. NOTURNAI 19-X-1984' 'MPEG HYM 11005585 ' (19, MPEG); 'Brasil Pará \Serra Norte\ N-1 C/LUZ\ CASA VISITAS\22-X-1984' 'Brasil Pará $\backslash$ T. Pimentel' 'MPEG HYM $\backslash 11005588$ ' (1 q, MPEG); 'Brasil Pará Serra Norte\ N-1 C/LUZ\ CASA VISITAS \22-X-1984' 'Brasil Parál T. Pimentel' 'MPEG 
HYM\11005591' (1ð̊, MPEG);'Brasil Parál Serra Nortel N3\20.vi.1985' 'MPEG HYM $\backslash 11005601$ ' (1 9 , MPEG); 'Brasil Pará Serra Norte\ N-1. C/LUZ\ 19-IX-1985' 'Brasil Pará J. Dias' 'MPEG HYM $\backslash 11005598$ ' (10̄, MPEG); 'Brasil Parál Tome Açul 18.IX.1978' 'Mata de terra firmel Isca luminosal Captura noturna' (4우, MPEG); 'BRASIL Parál Rio Trombetas\ LAGO JUGUIRI\ 6-III-1986\U. Barbosa' (19, INPA); 'BRASIL Parál Rio Trombetas $\backslash$ LAGO CAETANO\9-III1986 Eq.APOIDEA' (19, INPA); 'PA: BR-14 Km 93\ Belém-Brasílial Agoout.1959\ Exp.Dep.Zoo.' (1+9, MZUSP); 'Brasil Parál Bujarul 15.ix.1978' 'Brasil Para\R B Neto' (19, MPEG);'Brasil Pará Tucuruíl Rio Tocantis\ Base $4 \backslash 8$ a 22. II.1985' 'Brasil Parál N. Degallier' 'Armadilha\Interceptação' (1 9 , MPEG). Paraíba: MAMANGUAPE, PB\Res. Biol. Guaribas\Brasil, 14.1.1999\C. Schlindwein leg.' '13749 F:93\ Luz Negra 4:15' '285 UFPE' (1 9 , UFPE); 'MAMANGUAPE, PB $\backslash$ Res. Biol. Guaribas\Brasil, 14.1.1999\ C. Schlindwein leg.' '13748 F:93\ Luz Negra 4:15' '1200 UFPE' (1웅 UFPE). Pernambuco: 'Igarassu PE\ Usin. S. José: Macacos $\backslash$ Brasil 22.01.2010\ A.T. Carvalho leg.' 'L196\ luz negra' '61169' (19, UFPE); 'Igarassu PE। Usin. S. José: Macacos\ Brasil 22.01.2010\ A.T. Carvalho leg.' 'L196\ luz negra' '61170 UFPE' (19, UFPE); 'Paudalho, PE\ Brasil 24/11/2003\ Oliveira, H. leg.' '44465 UFPE' 'L119' (19, UFPE);'TAPACURÁ PE\ Brasil, 10.2000\ L. Pierrot leg.' '1823 UFPE' 'L 124\ sem anotações' 'Megalopta sp.2\ A1036 Ol Moure det.2000' (1 1 , UFPE). Rio Grande do Norte: 'Brasil, RN, Portalegre, Cachoeira do Pinga, $\backslash 06^{\circ} 00^{\prime} 58^{\prime}$ 'S 3759’30”W $\backslash 500 \mathrm{~m}, 21 . v .2007$, J.A.I Rafael \& F.F. Xavier Fo.,\ luz' (2+, DZUP); 'Brasil, R. G. Norte,\ Natal, III.1952,\ M. Alvarenga leg.' (1q, DZUP). Rondônia: 'Brasil, RO, Itapuãl do Oeste, Flonal do Jamari, 110m\ $9.260^{\circ} \mathrm{S} 62.913^{\circ} \mathrm{W} \backslash$ 4.ix.2012, Cavichioli\ Melo, Rosa \& Santos' 'Armadilhal Luminosa' (2 $9,15 \jmath^{\lambda}$ DZUP). 'Brasil, RO, Itapuãl do Oeste, Flonal do Jamari, 90m\ 9.146 ${ }^{\circ} \mathrm{S} 63.012^{\circ} \mathrm{W} \backslash$ 5.ix.2012, Cavichioli\ Melo, Rosa \& Santos' 'Armadilhal

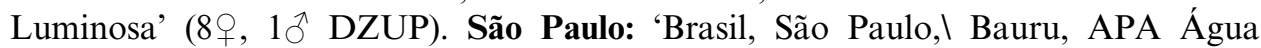
Limpa, $2^{\circ} 21^{\prime} S 4^{\circ} 00^{\prime} \mathrm{W} \backslash$ 09.x.2008, Ninho $1 \backslash$ L.M. Santos \& S. Tierney' (1의, DZUP); 'Brasil, São Paulo,\ Bauru, APA Água Limpa, $2^{\circ} 21^{\prime} \mathrm{S} 49^{\circ} 00^{\prime} \mathrm{W} \backslash 09$. x.2008, Ninho 4\ L.M. Santos \& S. Tierney' (1+1, DZUP); 'Brasil, São Paulo,। Bauru, APA Água Limpa, $\backslash 22^{\circ} 21^{\prime} S$ 4900’W $\backslash$ 09.x.2008, Ninho 5\ L.M. Santos \& S. Tierney' (3, DZUP); 'Fazenda Sta.Carlotal Cajuru-SP BR U.V.I 15/XI /1993 Mateus, S. leg.' (1오 DZUP); 'UNESP - Bauru, SP\ Brasil 10/12/1998\ Col. R. Marono P3\EUG EE' (1+, DZUP); 'Brasil, São Paulo,\São Carlos\25.ix.1995\ M. Costa' (1+, DZUP). Tocantins: 'BRASIL: GO\Ilha do Bananal\ Rio Javaré, 200m\14-19.ix.1985\V.O. Becker col.' (9, DZUP).

\section{Megalopta aeneicollis}

BRAZIL: Amazonas: 'BRASIL, Amazonas\ Barcelos, viii.2008\ Rio Aracál $0^{\circ}$ 37'11'S, 6252'34'W' 'Na luz, no barcol A. Filho \& R. Machado' (1ㅇ, 1ठ, INPA); 'BRASIL, Amazonas $\backslash$ Barcelos, Bacuquara $0^{\circ} 09^{\prime} 09^{\prime}$ N , 6310'38”W'\viii.2007' 'Luz mista Mercúriol A.S. Filho \& T. Krolow' (10,, INPA); 'BR, AMAZONAS, BARCELOS $\backslash$ RIO PADUARI, COM $\backslash$ ACUQUAIA, 8-10-VI-2010 $0^{\circ} 13$ '36' N/ 6359'20' W MIELKE \& CASAGRANDE LEG.' (1ㅇ, DZUP); 'BRAZIL: Amazons State,l Barcelos, Rio Paduari, Com. Aarão/Ararinha, 00.50487N

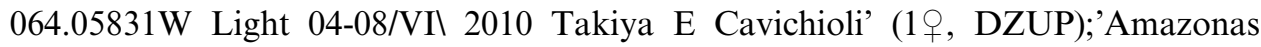
Manaus\ Parko 12.1941' 'Megaloptal amazonical P. Moure 1951'; 'Bento 
Mascarenhas $\backslash$ BRASIL: Amazonas $\backslash$ Reserva Campinas $\backslash$ BR 174, km 60\26\11\1976' (19, MPEG); 'BRASIL: Amazonas\ ESENA Juami-Japurál 0245'19.76'S $\backslash 67^{\circ}$ 36'50.29”'W' '04-17 agosto 2005\ L.S. Aquino leg.' (1 9 , INPA); 'Igarapé Belém\ Rio Solimões, AM $\backslash$ 7-30.IV.1966\ Malkin col' (2ㅇ, MZUSP); 'BRASIL: Amazonas $\backslash$ Reserva Campinas $\backslash 60$ km, N Manaus $\backslash$ XI-22-1976\B.C. Ratcllife' (1 9 , INPA); 'BRASIL: Amazonas $\backslash$ Reserva Campinas 60 km, N Manaus $\backslash$ III-3-1977\B. C. Ratcllife' (19, INPA); 'BRASIL - AMAZONAS\ MANAUS - RES. DUCKE। II/1995\ M.I.G. HOLVIN' (19, INPA); 'BRASIL, Amazonas, Manaus, \ Reserva Biológica de Campinal 11.vii.2008, 77m, 2³5'27'S $\backslash 60^{\circ} 1^{\prime} 51^{\prime}$ 'W luz P.C. Grossi'

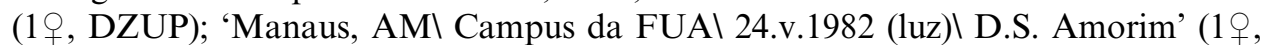
MZUSP); 'BRASIL-MANAUS AM\ EST. P/TARUMÃ KM $\backslash 13$ 19;12/1985 M.V. B. GARCIA' (1亏̄, MEUFV); 'BRASIL-MANAUS $\backslash$ AM $\backslash$ EST- P/TARUMÃ $\backslash K M$ 13\19/12/1985 M.V.B. GARCIA' (10̂,, DZUP); 'BRASIL Amazonas\ Manaus: FUAl 25-V-1982 F. PERALTA' (19, INPA); 'BRASIL Amazonas RIO CUIEIRAS $\backslash$ 23-24-VIII-1988\ F.J.A. Peralta' (1q, INPA); 'BRASIL- AMMANAUS $\backslash$ RESERVA- DUCKE\ 24-X-1976 col?' (19, INPA); '2934' 'Reserva Ducke\ Mn.Am.Brasil\ Fn 5/68\ Col-Faustino' (19, INPA); '19' 'Brasil Amazonas\ Campus - UAI 25.III.1982 A.T.S. Jatahy' (19, INPA); 'BRASIL: Amazonas\ CEPLAC AM010 KM30\13.X.1977 ALTAMIRO SOARES' (19, INPA); 'Brasil, Amazonas\CEPLAC, 30 km NE\ Manaus $12 . X \amalg .76$ 30-VI-77\ Col: B.C. Ratcliffe' (1ㅇ, INPA); 'BRA, Amazonas, Novol Aripuanã, lago Xadál 05¹5'39"S 60 42'32"W $\backslash$ iv.2005' 'Em luz mista e BLB $\backslash$ F. Xavier, F. Godoil \& A. Lourido Leg.' (1 9 , INPA); 'Brasil, AM, Pres. Figueiredo, $\backslash$ BR 174, km 180, R. Paulista, \25-26. I.2006, Arm luz móvel,' 'J.A. Rafael, F. Xavier F', Silva A,I J.S. Duarte \& D.M. Mendes' (1 $\partial^{\lambda}$, INPA); 'BR, AM, Pq. Nac. do Jaúl Mg.dir. baixo rio Jaúl $1^{\circ} 97^{\prime} \mathrm{S} / 61^{\circ}$ 45’W\ 27-28/X/1993\Motta, C.; Andreazze, R.I \& Vidal, J. col.' (1+, INPA); 'BR, AM, Pq. Nac. do Jaúl Mg.dir. baixo rio Jaúl 197’S/61²45’W 19-20/X/1993\Motta, C.; Andreazze, R.I \& Vidal, J. col.' 'Luz mista mercúriol Luz negra BL e BLB। Lençol' (1 9 , INPA); 'BR, AM, P. Nac. do Jaúl R. Jaú-Maranhoto M.E.I 201'S/64 27’W\ 8-10/IV/1994\Motta, C. et al. col' 'Lençol c/luz mista mercúrio, luz negra $\mathrm{BL}$ e BLB' (1q, INPA); 'BRASIL, Amazonas, Pq\ Nac. Jaú R. Carabinanil 0159S6132W. 07-17.iv.। 1994, C. Motta e outros' (5q, INPA); 'Brasill Amazonas\ PARNA do Jaúl 19-III à 05-IV-I 2003' 'M.L. Oliveira \&l J.A. Cunha leg.I Campinarana' (2o, INPA); 'BRASIL, Amazonas, Pq.I Nac. Jaú, Ig. Miratucal $1^{\circ}$ 57'8”S; 61 49'19'W' '14-29.vii.1993\ Andreazze, R.; Costa,W.I \& Aquino, L col.' 'lençol c/luz mistal mercúrio, luz negral BL e BLB' (1요 INPA); 'BRASIL, AM, Reserva Uninil Rio Unini, Lago 03 Bocas $\backslash 01^{\circ} 34$ '56”S, 62 58'28”W $\backslash 14-22$.vii.2004' 'Luz mista del mercúrio+BLB (lençol) $\backslash$ A. Silva F. \& L. Aquino' (4ㅇ, INPA); 'Brasil Amazonas/Parál Rio Nhammundá el Igarapé Areia, 17.V.2008,\01³5'11'S 057 37’32”W $\backslash$ D.M. Takyia light (19, DZUP); 'C.O.9, Tabatingal 18-1-1961\ amazonas' (1 $\circ$, INPA). Roraima: 'Brazil, Roraimal Mucajaí, Mucajaí river $02^{\circ} 46 \mathrm{~N} 62^{\circ} 16^{\prime} \mathrm{W}$ ' '5-mai-95\KYRSCH,C.' 'MIRR-0178' (19, MIRR).

\section{Megalopta nitidicollis}

BOLIVIA: La Paz: 'NIGRILLANI $\backslash$ NOR - YUNGAS $\backslash$ I - 50\WILLINER' (1 9 , DZUP). BRAZIL: Acre: ' Capixaba, Acrel armadilha luminosal mata contínua' (1 9 , DZUP); 'Rio Branco - Acl Brasil 06\06\1996\RECCO,R.D. leg' (1 9, DZUP); 'Rio 
Branco - AC $\backslash$ Brasil 20/4/1993\ E.F. MORATO' 'LUZ\ MIXTA' (29, INPA); 'BR AC Cruzeiro do Sul $61^{\circ}$ BIS Hotel de Trânsitol 07³6’26”S/ 7240'55” W $121-22 / \mathrm{XI} /$ 1996\Motta,C.S. et alii col' 'Luz mista mercúrio\ Luz negra BL e BLB\Lençol'

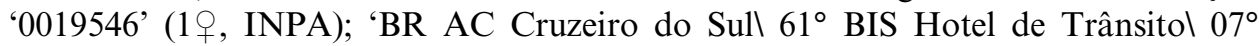
36'26”S/ 7240"55"W $\backslash 21-22 / X I / 1996 \backslash$ Motta,C.S. et alii col' 'Luz mista mercúriol Luz negra BL e BLB\Lençol' '0019547' (19, INPA). Amazonas: 'BRASIL AM, São Paulol de Olivença, Bonfim\ 13.ix.2005, arm. luz,\ J.A. Rafael \& F.F. Xavier F' ${ }^{\circ}(1 \hat{\jmath}$, INPA); 'Brasil, AM, Ipixuna, Riol Liberdade. Com. SãolVicente, Estirão da Preta, 175m, 7²1'47”S 7152'07”W 11-14.v.2011, R. Cavichioli' (1ㅇ, INPA); 'Brasil, Amazonas, Rio $\backslash$ Abacaxis $\backslash 140$ km SE, 26-28.v.2008 05¹5'09”S $\backslash 60^{\circ} 41^{\prime} 52^{\prime}$ W D.M. Takiyal luz' (19, DZUP); 'Brazil, Amazonas State,I Rio Abacaxis, Faxiúbal02. vi.2008 $01^{\circ} 28 \mathrm{~S} \backslash 58^{\circ} 34 \mathrm{~W}$, J.A. Rafael, \ D.M. Takiya et al. $\backslash$ light trap at 30m.' (1 , DZUP). Rondônia: 'BRASIL: RO\Ariquemes $180 \mathrm{~m}$ 13-\} 1 6 \text { iv.1989\ V.O. Becker' } (1q, DZUP); 'BRASIL: Rondônial Ji-Paranál 14-II-1983\ equipe J.R. Arias' (2o, INPA); 'Brasil Rondônia \Ji-Paraná Gleba G\Est.Rio Machado\14.VI-1983' 'Brasil

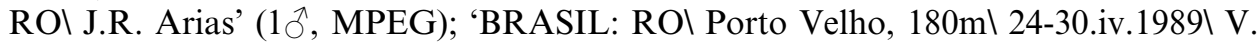
O. Becker' (2ᄋ, DZUP); 'BRASIL: RO\ Porto Velho, $180 \mathrm{~m} \backslash 2$-12.v.1989\ V.O. Becker' (19, DZUP); 'Brasil, RO, Itapuã \ do Oeste, Flonal do Jamari, $110 \mathrm{ml}$ 9.260 ${ }^{\circ} \mathrm{S} 62.913^{\circ} \mathrm{W} \backslash$ 4.ix.2012, Cavichioli\ Melo, Rosa \& Santos' 'Armadilhal Luminosa' (7ð DZUP); 'Brasil, RO, Itapuãl do Oeste, Flonal do Jamari, 90m। $9.146^{\circ} \mathrm{S} 63.012^{\circ} \mathrm{W} \backslash$ 5.ix.2012, Cavichiolil Melo, Rosa \& Santos' 'Armadilhal Luminosa' (2 §̊, DZUP). PERU: Junin: 'SATIPO- PERU\ $750 \mathrm{mrl}$ Coll. J.

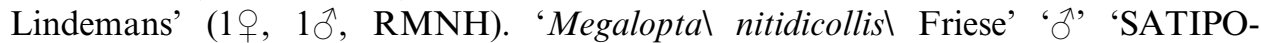
PERU $750 \mathrm{mr} \backslash$ Coll. J. Lindemans' (1Ō̄, RMNH); 'Megalopta $\backslash$ sulciventris $\backslash$ Friese'

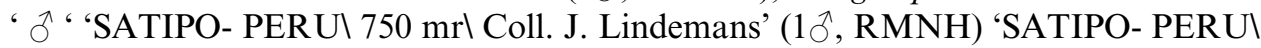

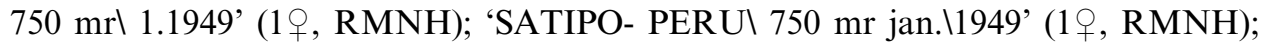
'Peru, PA, 3-4000 ft.I Yurinaki alto\4.X-67 P. Hocking' (19, MUSM). Loreto: 'Peru, LO, Maynas, Alpahuayo-Mishana KM 28 - Ex light trap\12vii01 Mario Callegari' 'col. CR col' (3 + , CRC); 'Peru, LO $\backslash$ A\&E Tours, frog valley\ Rio Tahuayo 27 vi01\

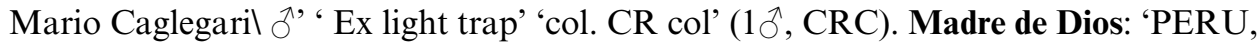
MD, Tamboatal Jungle Loldge, 225 masl $\backslash$ S12 49,456 N69 24, 163\9-20x01, C Rasmussen leg' 'Megalopta sp.l CR01' 'col. CR col' (2ð̂, CRC); 'PERU, MD, Tamboatal Jungle Lodge, 225 masl S12 49,456 N69 24, 163\ 9-20x01, C Rasmussen leg' 'col. CR col' $\left(3 \partial^{\top}, \mathrm{CRC}\right)$; 'Peru, Madre de Dios, $\backslash 5 \mathrm{~km}$ SW de St. Rosa, $\backslash 12.967^{\circ} \mathrm{S} 70.332^{\circ} \mathrm{W}, \backslash 404 \mathrm{~m}, 21 . v i i i .2012, \backslash \mathrm{R}$. Cavichioli'. (8ㅇ, 5ठ DZUP). 'Peru, Madre de Dios, $\backslash$ Manu, $9 \mathrm{~km}$ a SW del Mazuko, 364m, $\backslash 13.181^{\circ} \mathrm{S}, 70.384^{\circ}$

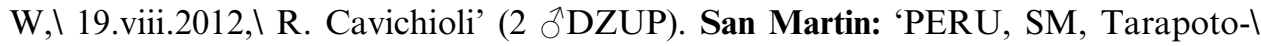
Yurimaguas, km 20\'BIODIVERSIDAD’ 0634/7620 950 masl\ IV-VI.2002 C. Rasmussen' 'Megalopta sp’ Det. Claus Rasmussen, 2002' ‘col. CR col' (1우, CRC);

\section{Megalopta sulciventris}

BRAZIL: Amapá: 'Brasil Amapá \ Amapari\ Tucano-2\ 9.XI.1983' 'Brasil AP\N. Bittencourt' 'Armadilhal de Luz' (2+,1ð̄, MPEG); 'Brasil Amapál Amaparil

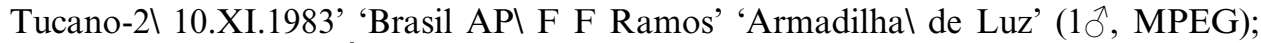
'Brasil: AP\TRACAJÁl -TUBA IX.64\ E. Denti col.' (1ㅇ, MZUSP); 'SERRA DO NAVIO\Terr. Amapá BRASL\Out.-1957\K. Lenko leg.' 'COLEÇÃO\CAMPOS SEABRA' (1, DZUP); Amazonas: 'BRASIL, AM, Barcelos,I Igarapé Erere/ 


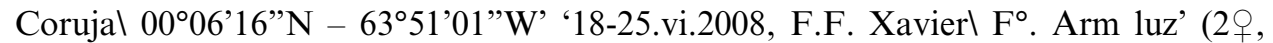
INPA); 'Beruri-AM/R. Purus\BRASIL 15.x.1991\ G.A.R. MELO' (1 'Brasil-Am-Manaus $\backslash$ I. Anavilhanas $\backslash$ 3-3-1976 PARALUPPI' (1 + , INPA); 'Brasil AM - Mn\ Anavilhanas\16/03/76\ Maurício' (19, INPA); 'BRASIL: Amazonas\ CEPLAC, AM 010 KM 30\ 13.X.1977 ALTAMIRO SOARES' (19, INPA); 'BRASIL: Amazonas\ CEPLAC, AM 010 KM 30\ 14.X.1977 ALTAMIRO SOARES' (19, INPA); BRASIL Amazonas Manaus RIO URUGU $\backslash$ 9-V-1983\F. PERALTA (1q, INPA); 'BRASIL Amazonas\ Manaus FUAl 25-V-1982 F.

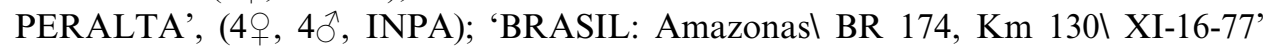
'Collector:\ B.C. Ratcliffe' (19, INPA); 'BRASIL, AM, Manaus $\backslash$ ZF-2 Km-14, torre

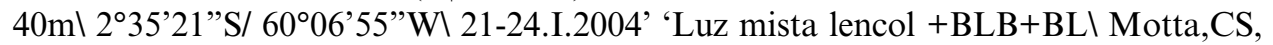
Trovisco, SF, Xavier FFF', Filho,AS. Col.' (11요요 INPA); 'BRASIL, AM, Manaus ZF2\ km-14, Torre,023521S-\600655W, 19-22.iii.2004\ luz mista/ BL, BLB, lençol'

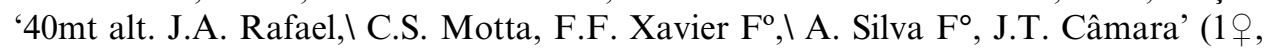
INPA); 'BRASIL, AM, Manaus ZF2\ km-14, Torre,023521S-\600655W, 16-19. iv.2004\ luz mista/ BLB, lençol' '40mts alt. J.A. Rafael, \ C.S. Motta, A. Silva F, J. M.F. Ribeiro' (19, INPA); 'BRASIL, AM, Manaus ZF2\ km-14, Torre,023521S-। 600655W, 18-21.v.2004\ lencol: luz mista e BLB' '40mts alt. J.A. Rafael,I F.B. Bacarro, F.F. Xavier $F^{\circ}, \backslash$ A. Silva $F^{\circ}$ ' (19, INPA); 'BRASIL, AM, Manaus ZF2। km-14, Torre, 023521S- $\backslash$ 600655W, 15-18.vi.2004\lencol: luz mista e BLB' '40mts alt. J.A. Rafael, \ C.S. Motta, F. Godoi, S.I Trovisco \& A. Silva F ${ }^{\circ}$ (3ㅇ, INPA); 'BRASIL, AM, Manaus ZF2\ km-14, Torre, 023521S-\600655W, 16-19.vii.2004\ lencol: luz mista e BLB' '40mts alt. J.A. Rafael, \ C.S. Motta, F.F. Xavier Fo, $\backslash$ J.M. F. Ribeiro \& S. Trovisco (2ᄋ, INPA); 'BRASIL, AM, Manaus ZF2 1 km-14, Torre, 023521S-\600655W, 13-16.viii.2004\ lencol: luz mista e BLB' '35mts alt. J.A. Rafael,। F.F. Xavier $F^{\circ}, \backslash$ A.R. Ururahy, $\backslash$ A. Silva, \& S. Trovisco (1요 INPA); 'BRASIL, AM, Manaus ZF-2\ km-14, Torre, 023521S- $\backslash$ 600655W, 13-16.ix.2004\ lencol: luz mista e BLB' ' $35 \mathrm{mts}$ alt. F.F. Xavier Fo,$\backslash$ A.R. Ururahy, F. Godoi, \&l S. Trovisco (3요 INPA); 'BRASIL, AM, Manaus ZF2\ km-14, Torre, 023521S- $600655 \mathrm{~W}, 12-15$. x.2004\lencol: luz mista e BLB' '35mts altura, J.A. Rafael, \C.S. Motta, F.F. Xavier $\mathrm{F}^{\circ}, \backslash$ A. Silva $\mathrm{F}^{\circ} \& \mathrm{~S}$. Trovisco (2ᄋ, INPA); 'BRASIL, AM, Manaus ZF-2\ km-14, torre, 023521S- $\backslash$ 600655W, 10-13.xii.2004\lencol: luz mista e BLB' '35mts altura, C.S. Motta, \A. Silva $F^{\circ}$, \& $\&$ M. Cutrin Leg.' (1 9 , INPA); 'BRASIL, Amazonas, Manaus,। ZF-2- Km 34, Base LBA,\09.viii.2008, 100m, 2³5’33”S $\backslash 60^{\circ} 12^{\prime} 52^{\prime \prime} \mathrm{W}$ luz P.C. Grossi' (19, DZUP); 'BRASIL, Amazonas, Manaus, I ZF-2- Km 34, Base LBA,I 10.viii.2008, 100m, 2³5’33”S $\backslash 60^{\circ} 12^{\prime} 52^{\circ}$ 'W luz P.C. Grosi' (1+9, DZUP); 'BRASIL, AM, Manaus $\backslash$ Torre ZF-2, 023521 S $\backslash 600655 W, 26 . X .2003$ ' 'J.A. Rafael, F.F. Xavier\ Filho \& A.S. Filho, Arm.I luz (lençol), 40mt alt. (4ㅇ, INPA); 'Brasil, AM, Pres. Figueiredo,\Am $240 \mathrm{Km}$ 12, Sítio água vival 18-22.xii.2006, Luz mista.' 'F.F. Xavier $F^{\circ}$, G.M. Lourindo,। P.K.M. Almeida \& D.M.M. Mendes' (19, INPA); 'AM Manaus\ Resv. Ducke\III.1977' 'Brasil, Amazônas\W L Overal Col.' 'Megalopta\ cf genalis $\backslash$ M.W. $\backslash$ Det. Camargo.82' (19, MPEG); 'BRASIL AM MANAUS $\backslash$ Torre da ZF-2/45m\2 2035’20”S/006’55”'W 06-07/I/1997\ Motta,C.S. \& Vidal, J. col' 'Luz mista mercúrio\ Lençol' '0019543' (19, INPA); 'BRASIL AM MANAUS $\backslash$ Torre da

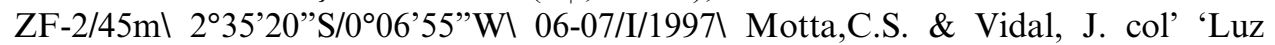
mista mercúriol Lençol' '0019544' (19, INPA); 'Brasil, Amazonas\ CEPLAC 30

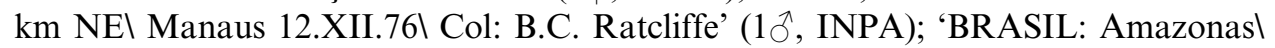
BR 174 ZF6 Km9\ Data. 04.07.86 Col. MVB Garcia' (19, MEUFV); 'BRASIL, 
AM, Manaus $\backslash$ Res. Biológica do Cuieiras $\backslash$ Base de apoio da ZF-2 $\backslash 02^{\circ} 35^{\prime} 21^{\prime \prime} \mathrm{S} 60^{\circ}$ 06'55'W $\backslash$ 24.x.2007, Torre 45mts' 'Lençol - Luz mista/BLB $\backslash$ J.A. Rafael; F.S.P. Godoi; R.J.P. Machado; A. Filho \& R.R. Cavichioli' (19, INPA); 'Brasil Amazonas\ Manaus-FUA\ 25-III-1982\ E.F. Ribeiro' (19, INPA); '3008' 'A. Faustino' 'Estr. Am. $1 \mathrm{Km}$ 64l Manaus, Amazonas\ Brasil 24-VIII-970' (19, INPA); 'Brasil, Amazonas, 60Km\ ao norte de Manaus, \11.IX.1991, G.A.R. Melol

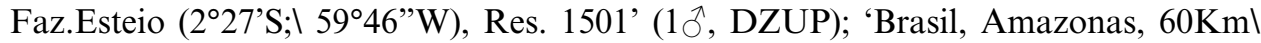
ao norte de Manaus, $\backslash$ 1.X.1991, G.A.R. Melo\ Faz. Esteio (2²7’S; $59^{\circ} 46^{\prime}$ W), Res. 1501\ Atraído a luz.' (19, DZUP); 'BRASIL: Amazonas $\backslash$ Reserva Campinas $\backslash$ BR 174, km.60\6-v-1977\ I.S. GORAYEB' (19, INPA); 'BRASIL: Amazonas $\backslash$ AM 010, Km.244\I-II-1977\ B.C. Ratcliffe' (1ㅇ, INPA); 'BRASIL, Amazonas, Riol Nhamundá, Ig. Areias $\backslash 01^{\circ} 35^{\prime} 11^{\prime}$ S - 57³7'32”W' '25m, 17-20.v.2008, J.A.l Rafael e equipe, arm. Luzl no barco' (3 + , INPA); 'Ipixuna - AM, Riol Liberdade. Com. SãolVicente (Estirão da\ Preta) 7²1'47”S $\backslash 71^{\circ} 52^{\prime} 7^{\prime \prime} W$ ' '175m Light trap $\backslash 11-14 / \mathrm{V} /$ 2011 \Cavichioli, Gonçalves \&lTakiya' (1q, DZUP); 'Brasil, Amazonas, \ Presidente Figueiredo, $2^{\circ} 12^{\prime}$ 'S 59 49'35”W, 14.ix.2009. L.D. Wendt' (1q, 1 o INPA);

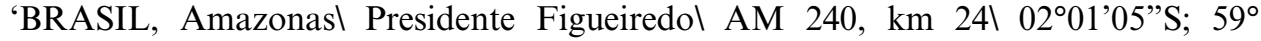
49'59”'W' 'Lençol, com luz mista\ 04-08.ix.2008\ F.F. Xavier F', T. K.I Krolow \& G. Lourido' (1ㅇ, INPA); 'BRASIL, AM, Manaus, \Reserva Ducke,\AM-010 km26।

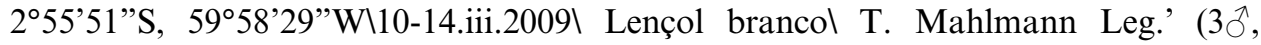
INPA); 'BRASIL, AM, Manaus, ZF-2\ km-14, Torre, 023521S - $1600655 \mathrm{~W}, 16-19$. iv.2004\luz mista/ BLB, lençol' '40mts altura, J.A. Rafael $\backslash$ C.S. Motta, A. Silva $F^{\circ} \backslash$ J. M.F. Ribeiro' (19, INPA); 'BRASIL, AM, Manaus, ZF-2\ km-14, Torre, 023521S -I 600655W, 16-19.iv.2004\ lençol: luz mista e BLB' '40mts altura, J.A. Rafael\ C.S. Motta, F.F. Xavier Fo ${ }^{\circ}$ J.M.F. Ribeiro \& S. Trovisco' (19, INPA); 'BRASIL, AM,

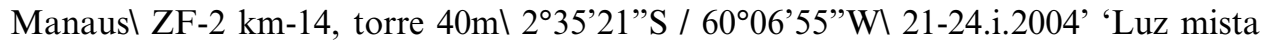
lençol + BLB+BLI Motta, CS, Trovisco SF, Xavier FFF, Filho, AS. Col.' (1 , INPA); 'Brasil, Amazonas, I Itapiranga, $300 \mathrm{Km}$ de\ Manaus, Armadilha\ luminosa,

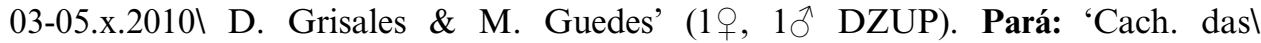
Guaribas $\backslash$ 14.8.' 'Brasil PA/AP\ Rio Jarí, 1961\ Dr. W. Egler' 'Megalopta $c f$. amoena $\backslash$ (Spinola)\ Det. Camargo.82' (1+, MPEG); 'Brasil: Parál ORIXININÁALCOA: MINER.I Ig. JUNDIRA 6-X-1982\ LUZ BRANCAI A.Y. Harada' 'Megalopta $s p \backslash$ M.C. Almeida-det 1985' (19, INPA); 'BRASIL: PA\ Belém, 20m\ 10-15.xi.1984\ V.O. Becker col' (1 $\circ$, DZUP); 'BRASIL: Pará Rio\ Poana a direital Subindo 6-X-85\ Eq. Comander' (19, INPA); 'Rod.Belém - \ Brasília Km 93\} 2 0 . xi.1959' (1+, MZUSP); 'BRASIL, Pará, Riol Nhamundá, \01³5'11”S - 57 37'32”W' '25m, 17-20.v.2008, J.A.I Rafael e equipe, Manual' (1 9 , INPA). Roraima: 'Brasil, Roraima, Amajaril Tepequém (SESC) $03^{\circ} 35^{\prime} \backslash 11.2^{\prime \prime} \mathrm{N} 61^{\circ}$ 42'53.7”W 630m' '16-abr-09 Gama Neto, J.L.I Pensilvânia' (19, MRRR). FRENCH GUIANA: Saint-Laurent-du-Maroni: 'FEVRER' 'GUYANEl NOUVEAU CHANTIER\BAS-MARONI' (1ㅇ, DZUP); 'FEVRER' 'GUYANE FRANÇAISE\ St-Laurent du Maronil Coll. LE MOULT' (1 9 , DZUP). French Guiana: Saint-Laurent-du-Maroni: 'FEVRER' 'GUYANEI NOUVEAU CHANTIERI BAS-MARONI' (1+, DZUP); 'FEVRER' 'GUYANE FRANÇAISEl St-Laurent du Maronil Coll. LE MOULT' (19, DZUP). SURINAME: Brokopondo: 'Suriname\Sarakreek\Lemmetje kondre\16 Dec. 1963। D.C. Geyskes' (4, RMNH); 'Surinamel Sarakreek Dann\17. Dec, 1963\ D.C. Geyskes\ op Licht' (1q, RMNH); 'Sipaliwini: 'Museum Leiden\W. Suriname Exp.। 
Kaboeri Creek\1st. Camp near Vinanna Creek $\backslash 25 . I I I .1971 \backslash$ D.C. Geijskes' (1 9 ,

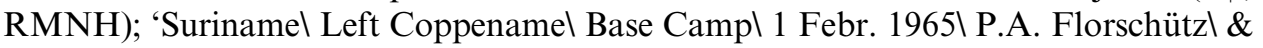
P.J.M. Maas' (1 1 , RMNH); 'Surinamel Upper Corantijn RiverlCoeroenil 18 June 1963\ J.G. Wessels Boer' 'at light' (19, RMNH); 'Surinamel Upper Corantijn RiverlCoeroenil 22 June 1963\ J.G. Wessels Boer' 'at light' (19, RMNH); 'Suriname\ Republiek\} 9 \text { May 1963\ J.v. de Vecht' 'at light' 'Megalopta\ idalia }

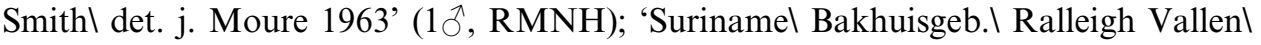
18 july $1963 \backslash$ R.v.aerde' (1 9, RMNH); 'Museum leiden\W. Suriname Exp. $\backslash$ Nickerie River\Stondansi $\backslash 28 . I-3 . I I .1971 \backslash$ D.C. Geijskes' (1 9, RMNH); 'Suriname\ Stondansil 22 sept $1962 \backslash$ J. Belle' (1 9, RMNH). Nickeri: 'Museum Leiden\W. Suriname Exp.l Maratakka River $\backslash$ Awarre-savanna\26.II-3.III.1971 D.C. Geijskes’ (1 , RMNH).

\section{Megalopta amoena}

BRAZIL: Acre: 'Brasil, Acrel Acrelândial 1004'S/ 67²5”'W' ‘02-04/XI/2001। Oliveira, Moratol \& Cunha leg.l benzil acetato' (19, INPA); 'BR AC Cruzeiro do

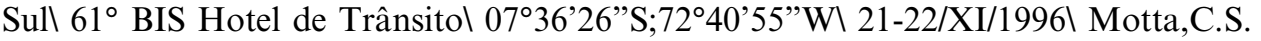
et alii col.' 'Luz mista mercúrio\ Luz negra BL e BLB $\backslash$ Lençol' (2o, INPA); 'BR AC Cruzeiro do Sul $\backslash 61^{\circ}$ BIS Hotel de Trânsitol 07³6’26”'S;7240'55”'W 20-21/XI/1996। Motta,C.S. et alii col.' 'Luz mista mercúriol Luz negra BL e BLB\Lençol' (1 9 , INPA); '115' 'Rio Branco-Ac\ Data: 04.03.99\ Albuquerque, E.S.I Veiga, S.A.' (1 $q$, INPA); Acre: '130' 'Rio Branco-Ac\ Data: 09.07.99\ Albuquerque, E.S.I Veiga, S.A.' (19, INPA); 'Rio Branco-ACl Data: 10/05/00\ Col. Naves, E.A.' (1 + , INPA); 'Rio Branco- ACl Brasil 20/04/1993 E.F. Morato' 'LUZ MIXTA' (1 $\circ$, INPA). Alagoas:

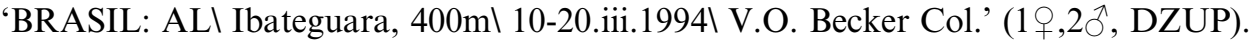
Amapá: 'Brasil-AP \01-XI-1981 \I.S. Gorayeb e equipe' 'MATA P/ \Armadilhal Suspensa 4m' (19, DZUP); 'Rio Felíciol Terr. Amapá BRASILI 8.VIII.1959\J. Lane leg.' (1ㅇ, DZUP); 'BRASIL:AP\TRACAJA-I TUBA. XI-64\E. Denti col. (1\%, MZUSP); 'OIAPOQUE - Amapá Brasil V-1959\ M. Alvarenga' (2ᄋ, DZUP). Amazonas: 'Tefél 11.8.1906\ Ducke' 'Brazil\ Estado dol Amazonas' (1今̄, DZUP); 'xxJapurál 16.6.1904\ Ducke' 'Brazil\ Estado do\Amazonas' (1今̄, DZUP); 'BRASIL Amazonas $\backslash$ Carauari - Margem $\backslash$ Esquerda rio Juruá, Com $\backslash$ Nova Esperança Ig. Do

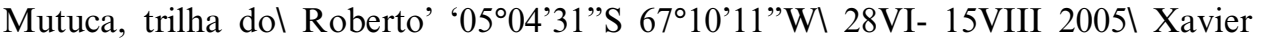
Filho, F.F. \&\ Henriques, A.L. leg' (19, INPA); 'Brasil, Amazonas, \ Rio Uneiuxi,

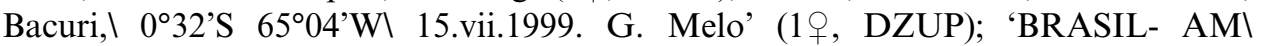
MANAUS $\backslash$ 14/OUT/2004\ J.C. ALMEIDA' (1+, INPA); 'BRASIL, AM, Presidentel Figueiredo, BR-174, Ramal\ do Km-200, 27.i.2006' 'J.A. Rafael, F.F.

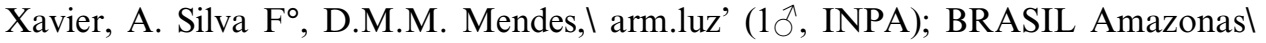
Novo Aripuanã, Riol Madeira, Lago Xadál Cmunidade Belal Vista. Ponto 1\ Margem Esquerda' '05¹5’39”S/6042’32”W. 17-23 IV 2005\ Xavier-Fo., F.F.; Godoi, F. \& Lourindo,\ A.M. leg' (1+, INPA); 'BRASIL Amazonas ESENA Juami-Japurá $\backslash 22^{\circ} 19^{\prime} 09^{\prime}$ 'S $\backslash 68^{\circ} 25^{\prime} 16^{\prime}$ W' '04-17 agosto 2005 L.S. Aquino leg.' (1, INPA); 'BR AM, Pq. Nac. do Jaúl Mg. Dir. baixo rio Jaúl $1^{\circ} 97$ ’S/6145” W $\backslash 27-28 / \mathrm{X} /$ 1993\ Motta, C.; Andreazze, R.I \& Vidal, J. col. (2q, INPA); 'BR AM, Pq. Nac. do

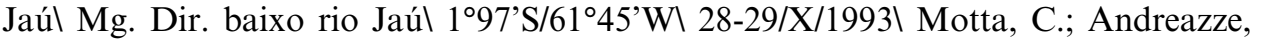
R.I \& Vidal, J. col. (1 9 , INPA); 'BRASIL, Amazonas, Pq.I Nac. Jau R. Carabinani.I 0159S-6132W.07-17.iv.\ 1994. C. Motta e outros' (5, INPA); 'Brasil $\backslash$ Amazonas\ PARNA do Jaúl 19-III à 05-IV-I 2003' 'M.L. Oliveira \&l J.A. Cunha leg.I 
Campinarana' (1ㅇ, INPA); 'Brasil $\backslash$ Amazonas $\backslash$ PARNA do Jaúl 19-III à 05-IV-I 2003' 'M.L. Oliveira \&\ J.A. Cunha leg. $\backslash$ Em igapó' (2ㅇ, INPA); 'Brasil \Amazonas\ PARNA do Jaúl 18 à 21-V-2003' 'M.L. Oliveira \&l J.A. Cunha leg.\Em igapó' (1 INPA); 'BRASIL Amazonas $\backslash$ Parque Nac. do Jaúl 17-19/nov/2005' 'M.L. Oliveira \& E.R.I F. Pereira leg $\backslash$ Floresta' (2ㅇ, INPA); 'BRASIL Amazonas $\backslash$ Parque Nac. do Jaúl 17-19/nov/2005' 'M.L. Oliveira \& E.R.I F. Pereira leg\ campinarana' (1옹, INPA); 'BRASIL. Amazonas\ ESENA Juami-Japurál Médio Rio Juamil 01 57’20.4”S $\backslash 67^{\circ} 55^{\prime} 47.8^{\prime}$ 'W' '23-29 xix. 2004\ M.L. Oliveira \& F.F.। Xavier Filho leg\ armailha de luz mista' (19, INPA); 'BRASIL Amazonas, Riol Cuieiras, Lago do peixel Boi 14.vi.1989. F.J.A.I Peralta. Arm luz mista' (19, INPA); 'BRASIL:

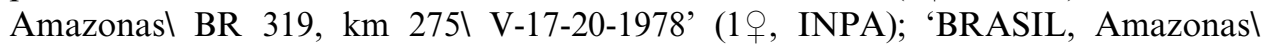
Manaus, Res. Duckel 09-22.ix.1994\ F.F. Xavier' 'Arm. suspensa\ Torre, 20m’ (1 , INPA); 'BRASIL, Amazonas $\backslash$ Manaus, ZF-2\ 09-22.ix.1994\ J.A. Rafael \& J. Vidal' 'Arm. suspensal Torre, 1,5m' (1q, INPA); 'BRASIL: Amazonas\ Manaus, Res. Ducke\ 07-21.xi.1994\ J.A. Rafael \& J. Vidal' ‘Arm. suspensal Torre, 10m' (2ᄋ, INPA); 'BRASIL: Amazonas\Manaus, Res. Duckel 07-21.xi.1994\ J.A. Rafael \& J. Vidal' 'Arm. suspensal Torre, 1,5m' (2ᄋ, INPA); 'BR, AM, Mun. Itacoatiaral Faz. Aruanã AM-010 km 215\14-15/I/1991\Motta, C.S. et al. col.' 'Luz mista mercúriol Luz negra Bl e BLB\ Lençol' '0019558' (19, INPA); 'BRASIL - Amazonas Anavilhanas\15/XI/1989\ M.L. Oliveira' (2q, INPA); 'BRASIL: Amazonas\ RESERVA DUCKE\ 15-X-1981 \J.A. Rafael' 'armadilhal de Malaise' (19, INPA); 'BRASIL: AMAZONAS\RIO CASTANHA\29-VIII-1979\ ROBIN BEST' (19, INPA); 'Brasil. Amazonas\ Manaus. Petropólis\ 01.v..88\ Leite S.S. col.' 'Halictidae' '130' (19, INPA); 'BRASIL, Amazonas\ Rio Jaú, Meriti\ Mun. Novo Airão' '04-10.vi.1994\ J.A. Rafael' (19, INPA); 'BRASIL-AM\MANAUS-AM 010

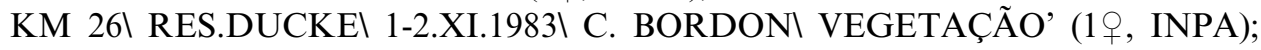
BRASIL:AM $\backslash$ R. DUCKE $\backslash 13-X-1981 \backslash J . A . ~ R A F A E L ' ~(19$, INPA); 'BRASIL: AMAZONAS $\backslash$ BR 174: KM 68: ZF-3\ FAZ. PORTO ALEGRE' 'FLORESTAL। 19-VI-1985\BERT.KLAIN' (1 9 , INPA); 'BRASIL AM MANAQUIRI $\backslash$ LAGO JANAUACA RIO\SOLIMÕES $\backslash 03^{\circ} 24$ '21”S/ 60¹3'99”'W' '12-IV-1996\ COLETA

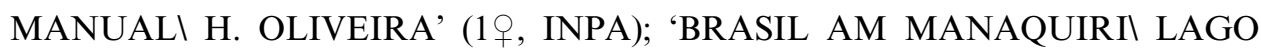
JANAUACA RIOI SOLIMÕES $\backslash$ 03²4'21"S/60¹3'99”'W' '20 IV 96। CARVALHO, K.S.' (1+9, INPA); 'BRASIL AM MANAQUIRI LAGO JANAUACA RIO \SOLIMÕES $\backslash 03^{\circ} 24^{\prime} 21^{\prime \prime S / ~ 60 ¹ 3 ' 99 ” W ~ 12 / 13 . I V .96 / ~ M O U R A, ~}$ J.F.L. (2ᄋ, INPA); 'BRASIL-AMAZONAS $\backslash$ MANAUS $\backslash 25 . V .82$ F.U.A.I LATORRE L.R.' (2 9 , INPA); 'BRASIL Amazonas\ Manaus: Rio Urubul 9-V1983\F. PERALTA' (3ㅇ, 1ठ, INPA); 'BRASIL: Amazonas\ RIO TARUMÃ $17-$

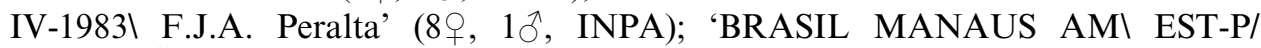
TARUMÃ kml 13 19/12/1985 M.V.B. Garcia' (1ठ̃, MEUFV); 'BRASIL

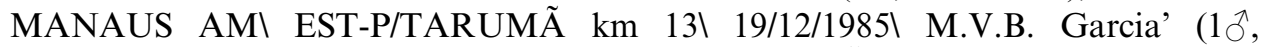
MEUFV); 'BRASIL MANAUS AM $\backslash$ EST-P/TARUMÃ km\} 1 3 \text { 19/12/1985 } \backslash \text { M.V. }

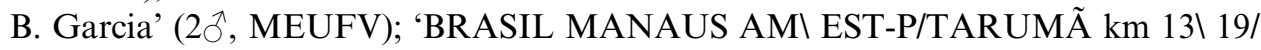

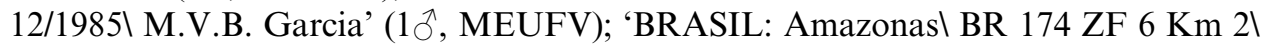
Data. 03.07.86\ Col. MVBGarcia' (1ð̄, MEUFV); 'BRASIL Am. Manaus\I. da Marchantarial Rio Solimões 14/03\ M.V.B. Garcia 1991' '2866' (1옹 DZUP); 'BENZIL ACETATO $\backslash N^{\circ} 15$ ' 'Manaus - AM $\backslash$ BRASIL, 19/9/88\ E.F. Morato' 'amoena (Spinola)' (19, DZUP); 'BENZIL ACETATO N No5' 'Manaus - AM BRASIL, 7/10/881 E.F. Morato' (19, DZUP); 'BRASIL: AMAZONAS। 
MANAUS. P. DAS LARANJEIRAS $\backslash 3$-VI-1981 $\backslash$ Eq. JORGE ARIAS $\backslash$ ARM. DE LUZ. 15M' (1 9 , INPA); '57' 'BRASIL-AM-MANAUS INPA. EST. ALEIXO ?-III-1975 col. L.P.A.' (19, INPA); 'BRASIL Amazonas $\backslash$ AM 0 Km 31 Embrapal 6-II-1992\ L.P. Albuquerquel J. Binda' 'Arm. Shannon\C. Cacau Isc Fruta\6-II-92' (1 9 , INPA); 'BR AM Pq Nac. do Jaúl Rio Carabinani mg. dir $\backslash 1^{\circ} 59 \mathrm{~S} / 61^{\circ} 32^{\prime} \mathrm{W} \backslash 11$ 12/IV/1994\Motta, C. et al. col.' 'Luz mista mercúrio \Luz negra BL e BLB $\backslash$ Lençol' (1 9 , INPA); 'BR AM Pq Nac. do Jaúl Rio Carabinani mg. dir $1^{\circ} 59 \mathrm{~S} / 61^{\circ} 32^{\prime} \mathrm{W} \backslash 13-$ 14/IV/1994\Motta, C. et al. col.' 'Luz mista mercúrio \Luz negra BL e BLB $\backslash$ Lençol' (1 9 , INPA); 'BR, AM, Pq Nac. do Jaúl Mg.dir. baixo rio Jaúl 24-25/X/1993\Motta, C.; Andreazze, R.I \& Vidal, J. col.' 'Luz mista mercúriol Luz negra BL e BLB\ Lençol' (1̧̂, INPA); 'BRASIL, Amazonas\ Parque Nacional Jaúl 8-16.iv.2001\ 015304S,613511W' 'Arm. Susp. - 20m\ Florestal Henriques \& Vidal' (19, INPA); 'BR AM MUN. ITACOATIARA FAZ. ARUANÃ AM010 km215\18-19/IX/1990\ MOTTA, C.S., FERREIRA, RLM \& ANDREAZZE, R col.' 'ARMADILHA DEI LUZ' (1 9 , INPA); 'Rio Negro, marg.esq.\abaixo I. Anavilhana\AM, 20-21.IV.1967\ Exp. Perm.Amaz.' (19, MZUSP); 'Ilha do Beiju-açu\ AM 23.x.969\ EPA' (1q, MZUSP); 'Brasil AM\ Marãa-R. Japurál Manguaril 11a17.x.1988' 'Armadilhal 1,6m\Suspensa' 'Brasil AM $\backslash$ J. Dias' (1을 DZUP); 'BRASIL, Amazonas, Manaus,। Reserva Biológica da Campinal 12.viii.2008, 77m, 2³5’27'S 60¹'51'W arm. luz dossell P.C. Grossi col. (2ð, DZUP); 'BRASIL-AM-MANAUS SÍTIO\VIDA TROPICAL\ ROD. AM-010 KM 30\ 20/21.IV.96/MOURA,J.F.L.' (19, INPA); 'BRASIL Amazonas\ Manaus, FUAI 25-V-1982 F. PERALTA' (19, DZUP); 'BRASIL AM PRESIDENTE\ FIGUEIREDO EST. BALBINAI KM12 27/28/

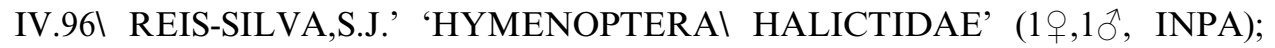
'Brasil, AM, Pres. Figueiredo, $\backslash$ BR 174, km 180, R. Paulistal 25-26.i.2006, Arm.

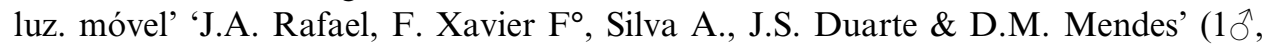
INPA); 'BRASIL, Amazonas\ Rio Aracá, Serrinha, 83m.a.I 00²5’09.3”N/63 23'00”W 30/viii/2007. Isca de cheirol M.L. Oliveira \& A.S. Filho leg.' (3ㅇ, INPA); 'BRASIL, Amazonas $\backslash$ Rio Aracá, Serrinha, 83m.a.l 00²5’09.3”N/ 6323’00”W $\backslash 30 /$ viii/2007. coleta manual\ M.L. Oliveira \& A.S. Filho leg.' (1요 INPA); 'BRASIL,

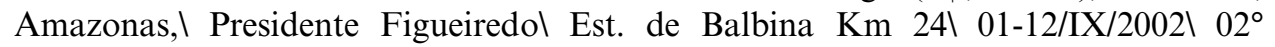
01'05”S, 5949'60”W' 'Felipe Filho, F.F. \&\ Barosa, U.C.I Varredura' (1옹 INPA); 'S. Antôniol do Içál 27.8.1906\ Ducke' 'Brazil Estado do\Amazonas' (10̄, DZUP); 'COLEÇÃO\CAMPOS SEABRA' 'TABATINGA\Amazonas BRASIL\ Outubro 1956 F.M. Oliveira' (19, DZUP); 'Brasil, Amazonas\ Rio Demeni-Pirico\08/22-

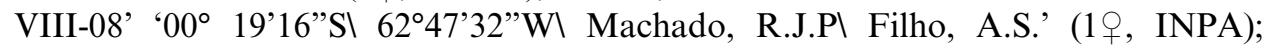
'BRASIL AM, Manaus, ZF2\ km-14, Torre, 023521S-\600655W, 16-19.iv.2004' (19, INPA); 'BRASIL, Amazonas Barcelos, viii.2008\Rio Aracál 0³7'11”S, 62

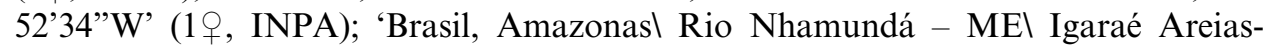

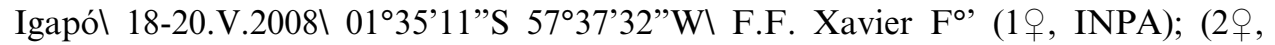
INPA); 'BRASIL AM, Manaus, ZF-I 2 km-34, Base LBA.I 02'35'37's - 60' 12'39'W' '09-10.viii.2008, arm. luzl nível do solo, J.A. Rafaell \& F.F. Xavier F' (4으, INPA); 'BRASIL, Amazonas $\backslash$ Rio Jufari\ Comunidade Cajú' '25/out/2008\00 48'10.3”S $\backslash 62^{\circ} 29^{\prime} 07.8 \mathrm{~W} \backslash$ M.L. Oliveira leg.' (1ㅇ, INPA); 'BRASIL, Amazonas $\backslash$ Rio

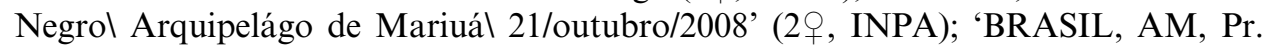
Figueiredol Rod. 240, km-24, Ramal São\Francisco, 29-31.x.2008' 'J.A. Rafael, F.F. Xavier F $F^{\circ}$ G.l Lourido, R.J.P. Machado \&l E. Amat. arm. luz solo’ (19, INPA); Bahia: 'BRASIL-BAHIA \Alagoinhas-Sauípel Data: 3 x 1993\Col: D.H. Smith' '966' 
(19, DZUP); 'BRASIL-BAHIA\ Alagoinhas-Sauípel Data: 16 x 1993\Col: D.H.

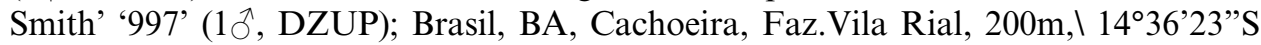
3853'47”W 14.v.2007, J.A. Rafaell \& F.F. Xavier Fo' (3ㅇ, DZUP); 'BRASIL: Brejões\25.vi.1999\ Lg. Miguel' (1ડ̂̃, DZUP); 'Brasil, BA, Lençois, \ Ribeirão de

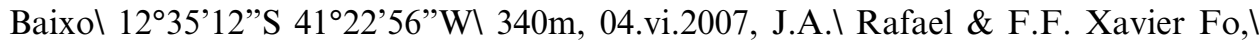

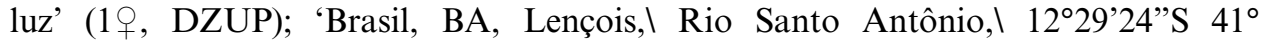
19’46”W\350m, 05.vi.2007, J.A.I Rafael \& F.F. Xavier Fo,। luz' (1ð’, DZUP);

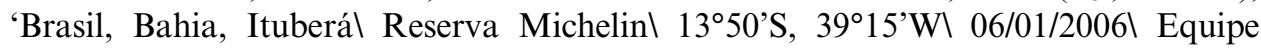
Ecopol Leg.' 'Fragmento P9 (P3)\Reserva da Michelin-\ Ba, Eucaliptol, 09:24। Fragmento/25ml estrato inferior.' (4ㅇ, UFBA); 'Brasil, Bahia, Ituberál Reserva Michelin $13^{\circ} 50^{\prime} \mathrm{S}, 39^{\circ} 15^{\prime} \mathrm{W} \backslash$ 06/01/2006 Equipe Ecopol Leg.' 'Fragmento P9 (P2)। Reserva da Michelin- $\backslash \mathrm{Ba}$, Salicilato, 09:05\ Fragmento/25m\ estrato inferior.' (1 ,

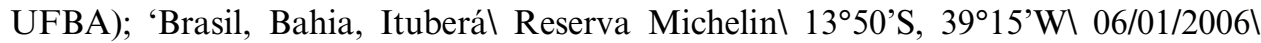
Equipe Ecopol Leg.' 'Fragmento P9 (P4)\ Reserva da Michelin- $\backslash$ Ba, Salicilato, 09:51\ Fragmento $25 \mathrm{ml}$ estrato superior.' (7ㅇ, UFBA); 'Brasil, Bahia, Ituberál Reserva

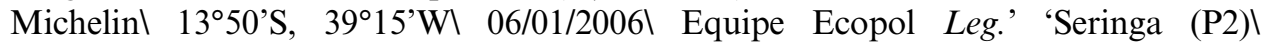
Reserva da Michelin- $\backslash \mathrm{Ba}(\mathrm{P} 1)$, Salicilato $11: 19$, Seringa/25\ estrato inferior.' (3우,

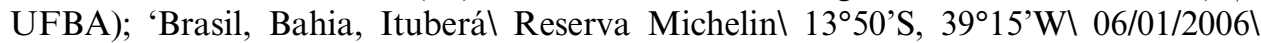
Equipe Ecopol Leg.' 'Pancada Grande,। Reserva da Michelin- $\backslash$ Ba (P1), Salicilatol 07:42, Mata/25ml estrato inferior.' (1 9 , UFBA); 'Brasil, Bahia, Ituberál Reserva

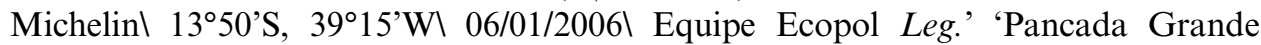
(MC1),\Reserva da\ Michelin-Ba\ Salicilato\ 07:48\ Mata/25m, estrato\ inferior.' (19, UFBA); 'Brasil, Bahia, Ituberál Reserva Michelin $\backslash 13^{\circ} 50^{\prime} \mathrm{S}, 39^{\circ} 15^{\prime} \mathrm{W} \backslash 06 / 01 /$ 2006\ Equipe Ecopol Leg.' 'Pancada Grande (MC1),\ Reserva dal Michelin-Bal Salicilato\ 07:49\ Mata/25m, estratol inferior.' (1운 UFBA); 'Brasil, Bahia, Ituberál

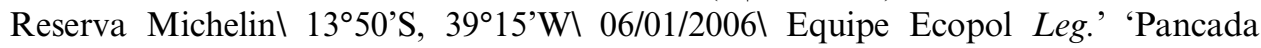
Grande (MC1), \ Reserva da\ Michelin-Ba\ Eucaliptol\ 13:02\ Mata/150m, estratol superior.' (19, UFBA); 'Brasil, Bahia, Ituberál Reserva Michelin $\backslash 13^{\circ} 50^{\prime} \mathrm{S}, 39^{\circ} 15^{\prime} \mathrm{W} \backslash$ 06/01/2006 Equipe Ecopol Leg.' 'Pancada Grandel (MC3), Reserva da\ Michelin-Bal Salicilato\10:35\ Mata/25m, estrato inferior.' (1ㅇ, UFBA); 'Brasil, Bahia, Ituberál

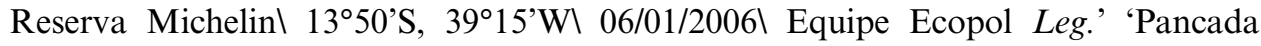
Grandel (MC4), Reserva dal Michelin-Bal Eucaliptol $108: 20 \backslash$ Mata/25m, estratol superior.' (5 9 , UFBA); 'Brasil, Bahia, Ituberá,\ Michelin $13^{\circ} 50^{\prime} \mathrm{S} 39^{\circ} 15^{\prime} \mathrm{W} \backslash 22 / 01 /$ 2006\ Equipe Ecopol' 'CA 2, Reserva Michelin-\ BA, 16:15' (2 9 , UFBA);'Brasil,

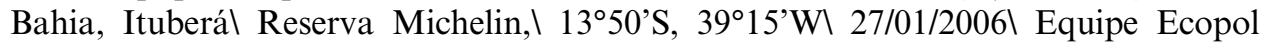
Leg.' 'Pacangê, Reserva da\ Michelin-Ba (P1),\Eucaliptol, 09:05,\ Mata/150,estratol inferior.' (6ㅇ, UFBA); 'Brasil, Bahia, Ituberál Reserva Michelin, $\backslash 13^{\circ} 50^{\prime} \mathrm{S}, 39^{\circ} 15^{\prime} \mathrm{W} \backslash$ 27/01/2006 Equipe Ecopol Leg.' 'Pacangê, Reserva da\ Michelin-Ba (P2), \Salicilato 10:15,\ Mata/150, estratol inferior.' (4+, UFBA); Brasil, Bahia, Ituberá, \ Reserva Michelin, $\backslash 13^{\circ} 50^{\prime} \mathrm{S} 39^{\circ} 15^{\prime} \mathrm{W} \backslash 29 / 01 / 2006 \backslash$ Equipe Ecopol Leg.' 'Fragmento P9 (P1),। Reserva da Michelin- $\backslash$ BA, Salicilato, 08:45 $\backslash$ Fragmento/25m, estrato $\backslash$ inferior.' (20 UFBA); 'Brasil, Bahia, Ituberá $\backslash$ Michelin, $\backslash 13^{\circ} 50^{\prime} \mathrm{S} \backslash 39^{\circ} 15^{\prime} \mathrm{W}$ 03/03/2006 Equipe Ecopol' 'SCA1, Reserval Michelin-BA,\ Salicilato de metila, 9:14, Seringa' (1웅, UFBA); 'Brasil, Bahia, Ituberá, $\backslash$ Michelin 1350'S 39² $15^{\prime} \mathrm{W} \backslash 03 / 03 / 2006 \backslash$ Equipe Ecopol' 'SCA2,Reserval Michelin-BA,I Salicilato de metila, 9:35, Seringa' (1 , UFBA); 'Brasil, Bahia, Ituberá,\ Michelin 1350'S 39² $15^{\prime} \mathrm{W} \backslash 03 / 03 / 2006 \backslash$ Equipe Ecopol' 'V-7-Mata (P1), \ Reserva Michelin\BA, Salicilato de\ Metila, 9:50, Mata' (1 9 , UFBA); 'Brasil, Bahia, Ituberá, $\backslash$ Michelin $13^{\circ} 50^{\prime} \mathrm{S} \backslash 39^{\circ} 15^{\prime} \mathrm{W}$ 03/03/2006 Equipe 
Ecopol' 'V7-Mata (P1), Reserval Michelin-BA,Vanilinal 09:50, Mata' (1 9 , UFBA); 'Brasil, Bahia, Ituberá, $\backslash$ Michelin 1350'S 39¹5'W 03/03/2006\ Equipe Ecopol' 'V-7Mata (P2), $\backslash$ Reserva Michelin- $\backslash$ BA, Salicilato de $\backslash$ metila, 10:05, Mata' (1ㅇ, UFBA); 'Brasil, Bahia, Ituberá,। Michelin 1350'S 39² $15^{\prime} \mathrm{W} \backslash 05 / 03 / 2006$. Equipe Ecopol' 'Ponto 9, Reserva dal Michelin-BA, Salicilato del metila,08:30. Seringa/25m.l Estrato inferior' (1+, UFBA); 'Brasil, Bahia,। Ituberá, Reserval Particular Michelin $\backslash 13^{\circ} 50^{\prime} S, 39^{\circ} 15^{\prime} \mathrm{W} \backslash$ 05/03/2006. Equipel Ecopol Leg' 'Pacangê, Reserva da\ Michelin-BA.I Salicilato de metila, $\backslash 8: 15$. Mata/25m.। Estrato inferior' (1ㅇ, UFBA); 'Brasil, Bahia, Salvador $\backslash$ Paralela\ 1258'S; 38²6’W 31/07/2000\ Batista, M.A. Leg' 'Bahia, Salvador $\$ Paralela (P2) Ess:3 $\backslash$ armadilha luminosa' (1 9 , UFBA);

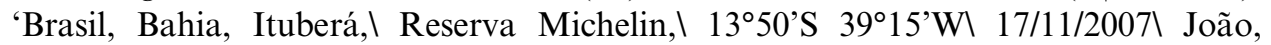
Zafira \&l Daniela Leg.' 'Fragmento do Cortel Alto (P1) Reserval Michelin-BA,I

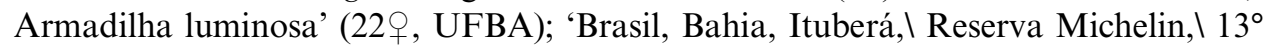
50’S 39² $15^{\prime} \mathrm{W} \backslash 17 / 11 / 2007 \backslash$ João, Zafira \&\ Daniela Leg.' 'Mata da Pancadal Grande (P1) Reserval Michelin-BA,I Armadilha luminosa' (19, UFBA);'Brasil, Bahia,

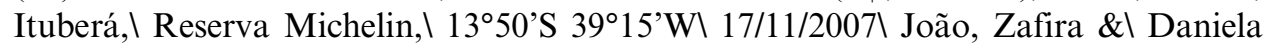
Leg.' 'Mata da Pancada\Grande (P2) Reserva\ Michelin-BA, $\backslash$ Armadilha luminosa' (3ㅇ, UFBA); 'Brasil, Bahia, Ituberál Reserva Michelin, $\backslash 13^{\circ} 50^{\prime} \mathrm{S}, 39^{\circ} 15^{\prime} \mathrm{W} \backslash 17 / 11$ / 2007\ João, Zafira \&\ Daniela Leg.' 'Mata da Pancadal Grande (P3) Reserval Michelin-BA,\ Armadilha luminosa' (3ㅇ, UFBA); 'Brasil, Bahia, Ituberál Reserva Michelin, $\backslash 13^{\circ} 50^{\prime} \mathrm{S}, 39^{\circ} 15^{\prime} \mathrm{W} \backslash 17 / 11 / 2007 \backslash$ Ramalho \& Dantas $\backslash$ Leg.' 'Fragmento do\ Pacangê 1, Reserval Michelin-BA,। Armadilha luminosa' (3ㅇ, UFBA); 'Brasil, Bahia, Ituberá,\Reserva Michelin, $\backslash 13^{\circ} 50^{\prime}$ S 39² $15^{\prime} \mathrm{W} \backslash 17 / 11 / 2007 \backslash$ João, Zafira \&l Daniela Leg.' 'Mata da Sede,\ Reserva Michelin-\BA, Armadilha\ luminosa' (2ᄋ,

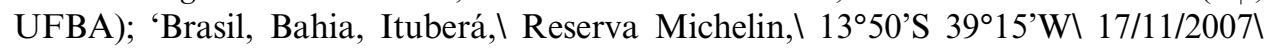
João, Zafira \&\ Daniela Leg.' 'Borda de Mata\ Reserva Michelin-\BA, Armadilhal luminosa' (1ㅇ, UFBA);'Brasil, Bahia, Ituberá, \ Reserva Michelin, $\backslash 13^{\circ} 50^{\prime} \mathrm{S} 39^{\circ} 15^{\prime} \mathrm{W} \backslash$ 17/11/2007\ João, Zafira \&\ Daniela Leg.' 'Mata do Guigó (P1)\Reserva Michelin-। BA, Armadilha\ luminosa' (3, UFBA); 'Brasil, Bahia, Ituberá,\ Reserva Michelin,। 1350'S 39¹5'W 17/11/2007\ João, Zafira \& Daniela Leg.' 'Mata do Guigó (P2)\ Reserva Michelin-। BA, Armadilhal luminosa' (1ㅇ, UFBA); 'Brasil, BA, Ituberá,। Michelin,\Mata do Guigó,\P2\Armadilha luminosa\17.XI.2007\ Leg. João, Zafira, Daniela' (2ᄋ, UFBA); 'Brasil, Bahia, Salvador $\backslash$ Paralela, $\backslash 12^{\circ} 58^{\prime} \mathrm{S}$; 38 $38^{\circ} 6^{\prime} \mathrm{W} \backslash 22 / 03 /$ 2000\Batista, M.A. Leg' 'Bahia, Salvador $\backslash$ Paralela (P2) Ess:2 5:00h, armadilhal luminosa' (10 $\circ$, UFBA); 'Brasil, Bahia, Salvador $\backslash$ Paralela, $\backslash 12^{\circ} 58^{\prime} \mathrm{S}$; 38 $26^{\circ} \mathrm{W} \backslash 22 / 03 /$ 2000\Batista, M.A. Leg' 'Bahia, Salvador $\backslash$ Paralela (P1) Ess:2 5:00h, armadilhal luminosa' (3ㅇ, UFBA); 'Brasil, Bahia, Salvador $\backslash$ Paralela, $\backslash 12^{\circ} 58^{\prime} \mathrm{S}, 38^{\circ} 26^{\prime} \mathrm{W} \backslash 22 / 03 /$ 2000\Batista, M.A. Leg' 'Bahia, Salvador $\backslash$ Paralela (P3) Ess:4\ 5:00h, armadilhal

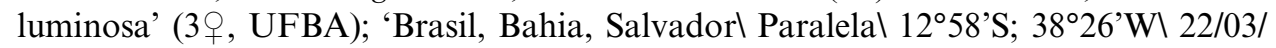
2000\Batista, M.A. Leg' 'Bahia, Salvador $\backslash$ Paralela (P2) Ess:4\ 5:00h, armadilhal luminosa' (1ㅇ, UFBA);'Brasil, Bahia, Salvador\ Paralela, $\backslash 12^{\circ} 58^{\prime} \mathrm{S}, 38^{\circ} 26^{\prime} \mathrm{W} \backslash 22 / 03$ / 2000\Batista, M.A. Leg' 'Bahia, Salvador $\backslash$ Paralela (P3) Ess:5\ armadilha luminosa' (19, UFBA); 'Brasil, Bahia, Salvador\ Paralelal 1258'S; $38^{\circ} 26^{\prime} \mathrm{W} \backslash 22 / 03 / 2000 \backslash$ Batista, M.A. Leg' 'Bahia, Salvador\ Paralela (P1) Ess:5\ armadilha luminosa' (13ㅇ, UFBA); 'Brasil, Bahia, Salvador \ Paralelal 1258'S; $38^{\circ} 26^{\prime} \mathrm{W} \backslash 22 / 03 / 2000 \backslash$ Batista, M.A. Leg' 'Bahia, Salvador $\backslash$ Paralela (P2) Ess:5 5:00h, armadilha luminosa' (12ㅇ, UFBA); 'Brasil, Bahia, Salvador \ Paralelal 1258'S; $38^{\circ} 26^{\prime} \mathrm{W} \backslash 22 / 03 / 2000 \backslash$ Batista, M.A. Leg' 'Bahia, Salvador $\backslash$ Paralela (P1) Ess:3\ 5:00h, armadilha\ luminosa' 
(329, UFBA); 'Brasil, Bahia, Salvador $\backslash$ Paralela,\ $12^{\circ} 55^{\prime} \mathrm{S}, 38^{\circ} 23^{\prime} \mathrm{W} \backslash 30 / 05 / 2000 \backslash$ Batista, M.A. Leg' 'Bahia, Salvador\ Paralela (P1) Ess:5\ armadilha luminosa' (10, UFBA); 'Brasil, Bahia, Salvador\ Paralela,\ $12^{\circ} 58^{\prime} \mathrm{S}, 38^{\circ} 26^{\prime} \mathrm{W} \backslash 30 / 05 / 2000 \backslash$ Batista, M.A. Leg' 'Bahia, Salvador $\backslash$ Paralela (P2) Ess:2\ armadilha luminosa' (1ㅇ, UFBA); 'Brasil, Bahia, Salvador $\backslash$ Paralela, $\backslash 12^{\circ} 58^{\prime}$ 'S, 38²6’W $\backslash 30 / 05 / 2000 \backslash$ Batista, M.A. Leg' 'Bahia, Salvador $\backslash$ Paralela (P1) Ess:2 $\$ 5:00h, armadilha\luminosa' (3ㅇ, UFBA); 'Brasil, Bahia, Salvador Paralela, $\backslash 12^{\circ} 57^{\prime} \mathrm{S}, 38^{\circ} 25^{\prime} \mathrm{W} \backslash 30 / 05 / 2000 \backslash$ Batista, M. A. Leg' 'Bahia, Salvador $\$ Paralela (P2) Ess:3 $\backslash$ 5:00h, armadilha\ luminosa' (2o, UFBA); 'Brasil, Bahia, Salvador $\backslash$ Paralela,\ $12^{\circ} 58^{\prime} \mathrm{S}, 38^{\circ} 26^{\prime} \mathrm{W} \backslash 30 / 05 / 2000 \backslash$ Batista, M.A. Leg' 'Bahia, Salvador $\backslash$ Paralela (P1) Ess:4\ 5:00h, armadilha\luminosa' (2o, UFBA); 'Brasil, Bahia, Salvador $\backslash$ Paralela, $\backslash 12^{\circ} 57^{\prime} \mathrm{S}, 38^{\circ} 25^{\prime} \mathrm{W} \backslash 30 / 05 / 2000 \backslash$ Batista, M. A. Leg' 'Bahia, Salvador $\backslash$ Paralela (P2) Ess:5 $\backslash$ 5:00h, armadilha\ luminosa' (1ㅇ, UFBA); 'Brasil, Bahia, Salvador $\backslash$ Paralela, $\backslash 12^{\circ} 58^{\prime}$ S, 38 $26^{\circ} \mathrm{W} \backslash 30 / 05 / 2000 \backslash$ Batista, M.A. Leg' 'Bahia, Salvador $\backslash$ Paralela (P1) Ess:3\5:00h, armadilha\ luminosa' (2o, UFBA); 'Brasil, Bahia, Salvador $\backslash$ Paralela $12^{\circ} 55^{\prime}$ S; 38²3’W $\backslash 30 / 05 / 2000 \backslash$ Batista, M. A. Leg' 'Bahia, Salvador $\backslash$ Paralela (P3) Ess:5 $\backslash$ armadilha luminosa' (1ㅇ, UFBA);

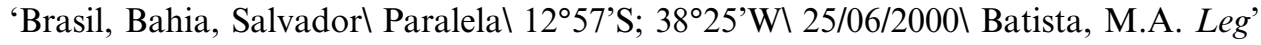
'Bahia, Salvador\ Paralela (P3) Ess:4\ armadilha luminosa' (2ᄋ, UFBA); 'Brasil,

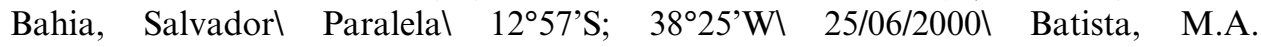

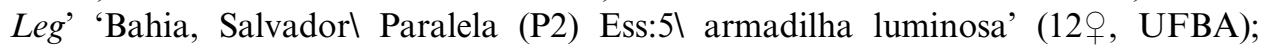
'Brasil, Bahia, Salvador\ Paralelal $12^{\circ} 55^{\prime} \mathrm{S}$; $38^{\circ} 23^{\prime} \mathrm{W} \backslash$ 25/06/2000\ Batista, M.A. Leg' 'Bahia, Salvador\ Paralela (P3) Ess:5\ armadilha luminosa' (89, UFBA); 'Brasil, Bahia, Salvador\ Paralelal $12^{\circ} 55^{\prime} \mathrm{S}$; $38^{\circ} 23^{\prime} \mathrm{W} \backslash 25 / 06 / 2000 \backslash$ Batista, M.A. Leg' 'Bahia, Salvador\ Paralela (P3) Ess:5\ armadilha luminosa' (1운, UFBA); 'Brasil, Bahia, Salvador $\backslash$ Paralelal $12^{\circ} 58^{\prime}$ S; 38 $26^{\circ} \mathrm{W} \backslash 26 / 06 / 2000 \backslash$ Batista, M.A. Leg' 'Bahia, Salvador\ Paralela (P1) Ess:5\ armadilha luminosa' 'UFBAl 04103'

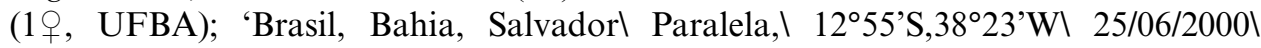
Batista, M.A. Leg' 'Bahia, Salvador $\backslash$ Paralela (P3) Ess:4\17:30, armadilha\ luminosa'

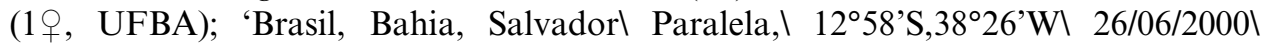
Batista, M.A. Leg' 'Bahia, Salvador $\backslash$ Paralela (P1) Ess:5\ armadilha luminosa' (6우, UFBA); 'Brasil, Bahia, Salvador $\backslash$ Paralela\ $12^{\circ} 58^{\prime}$ S; 38²6’W $\backslash 31 / 08 / 2000 \backslash$ Batista, M. A. Leg' 'Bahia, Salvador $\backslash$ Paralela (P1) Ess:3\ armadilha luminosa' (10웅 UFBA); 'Brasil, Bahia, Salvador $\backslash$ Paralela,\ $2^{\circ} 57^{\prime}$ S, $38^{\circ} 25^{\prime} \mathrm{W} \backslash 31 / 08 / 2000 \backslash$ Batista, M.A. Leg' 'Bahia, Salvador\ Paralela (P2) Ess:2l armadilha luminosa' (6ㅇ, UFBA);

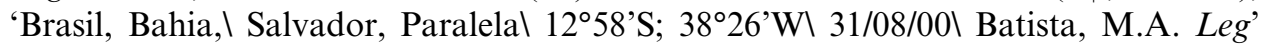
'Bahia, Salvador Paralela (P1) Ess:5\ armadilhal luminosa' (13웅 UFBA);

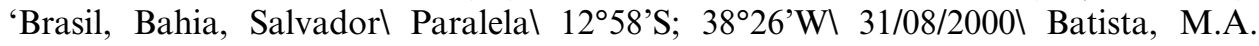
Leg' 'Bahia, Salvador\ Paralela (P2) Ess:3\ armadilha luminosa' (5ㅇ, UFBA);

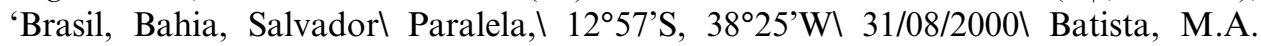

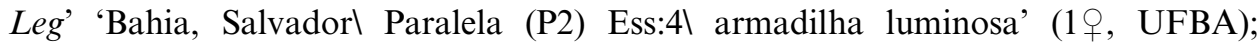
'Brasil, Bahia, Salvador $\backslash$ Paralelal $12^{\circ} 58^{\prime}$ S; 38²6’W 31/08/2000\ Batista, M.A. Leg' 'Bahia, Salvador\ Paralela (P1) Ess:3\ armadilha luminosa' (5, UFBA); 'Brasil, Bahia, Salvador Paralelal 1258'S; $38^{\circ} 26^{\prime} \mathrm{W} \backslash 31 / 08 / 2000 \backslash$ Batista, M.A. Leg' 'Bahia, Salvador\ Paralela (P2) Ess:3\ armadilha luminosa' (4ㅇ, UFBA);

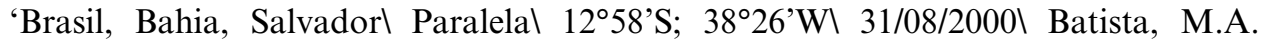

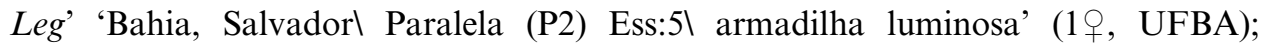
'Brasil, Bahia, Salvador Paralelal 1258'S; $38^{\circ} 26^{\prime} \mathrm{W} \backslash 10 / 10 / 2000 \backslash$ Batista, M.A. Leg' 'Bahia, Salvador\ Paralela (P1) Ess:5\ armadilha luminosa' (13ㅇ, UFBA); 
'Brasil, Bahia, Salvador $\backslash$ Paralela\ $12^{\circ} 58^{\prime}$ S; 38²6’W $\backslash 10 / 10 / 2000 \backslash$ Batista, M.A. Leg' 'Bahia, Salvador\ Paralela (P2) Ess:3\ armadilha luminosa' (1 9 , UFBA); 'Brasil,

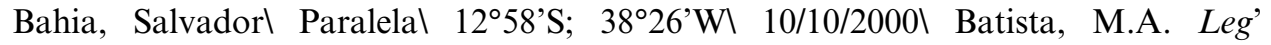
'Bahia, Salvador $\backslash$ Paralela (P2) Ess:5\ armadilha luminosa' (3ㅇ, UFBA); 'Brasil,

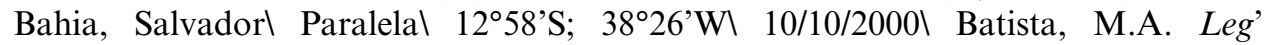
'Bahia, Salvador\ Paralela (P1) Ess:3\ armadilha luminosa' (1 9 , UFBA); 'Brasil,

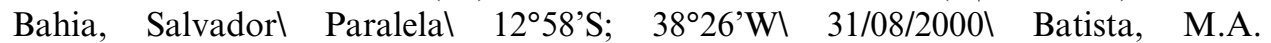
Leg' 'Bahia, Salvador\ Paralela (P1) Ess:3\ armadilha luminosa' (3ㅇ, UFBA);

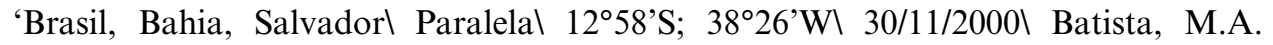
Leg' 'Bahia, Salvador\ Paralela (P1) Ess:5\ armadilha luminosa' (19, UFBA);

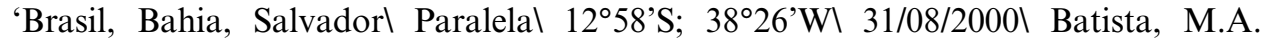
Leg' 'Bahia, Salvador\ Paralela (P2) Ess:3\ armadilha luminosa' (19, UFBA);

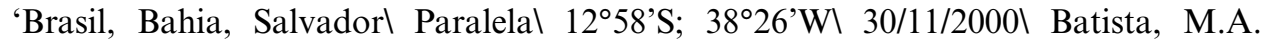

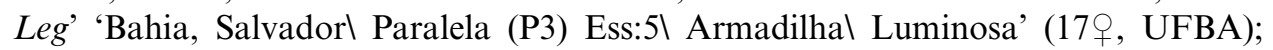
'Brasil, Bahia, Salvador $\backslash$ Paralela, $\backslash 12^{\circ} 55^{\prime} \mathrm{S} 38^{\circ} 23^{\prime} \mathrm{W} \backslash 30 \backslash 11 \backslash 2000 \backslash$ Batista, M.A. Leg' 'Bahia, Salvador $\backslash$ Paralela (P3) Ess:5 5:00h, armadilhal luminosa' 'UFBA\ 04230' (6ᄋ, UFBA); 'Brasil, Bahia, Salvador\ Paralelal 1258'S; $38^{\circ} 26^{\prime} \mathrm{W} \backslash 30 / 11 / 2000 \backslash$ Batista, M.A. Leg' 'Bahia, Salvador\ Paralela (P1) Ess:3\ Armadilha\ Luminosa'

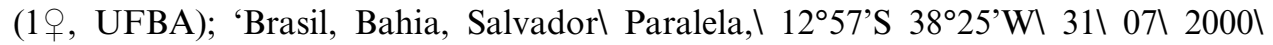
Batista, M.A. Leg' 'Bahia, Salvador\ Paralela (P2) Ess:5\ armadilha luminosa' (37으, UFBA); 'Brasil, Bahia, Salvador \ Paralelal 1258'S; $38^{\circ} 26^{\prime} \mathrm{W} \backslash 31 / 07 / 2000 \backslash$ Batista, M.A. Leg' 'Bahia, Salvador $\backslash$ Paralela (P1) Ess:5 5:00h, armadilha\ luminosa'

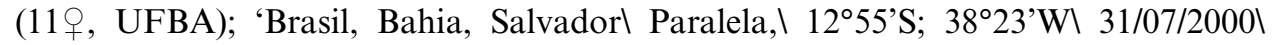
Batista, M.A. Leg' 'Bahia, Salvador $\backslash$ Paralela (P2) Ess:5\ armadilha luminosa'

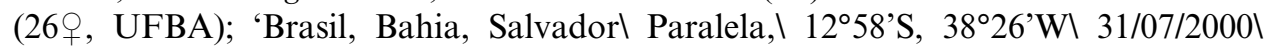
Batista, M.A. Leg' 'Bahia, Salvador $\backslash$ Paralela (P1) Ess:3 $\$ 5:00h, armadilha luminosa' (1ㅇ, UFBA); 'Brasil, Bahia, Salvador\ Paralelal 1255'S; $38^{\circ} 23^{\prime} \mathrm{W} \backslash 31 / 07 / 2000 \backslash$ Batista, M.A. Leg' 'Bahia, Salvador\ Paralela (P2) Ess:4.I Armadilhal Luminosa' (19, UFBA); 'Brasil, Bahia, Salvador\ Paralelal 1258'S; $38^{\circ} 26^{\prime} \mathrm{W} \backslash 31 / 07 / 2000 \backslash$ Batista, M.A. Leg' 'Bahia, Salvador $\backslash$ Paralela (P2) Ess:4.\ Armadilha\ Luminosa' (1ㅇ, UFBA); 'Brasil, Bahia, Salvador Paralela, $12^{\circ} 58^{\prime}$ 'S $38^{\circ} 26^{\prime} \mathrm{W} \backslash 30 \backslash 11 \backslash 2000 \backslash$ Batista, M.A. Leg' 'Bahia, Salvador $\backslash$ Paralela (P2) Ess:3\ armadilha luminosa' (1 9 , UFBA); 'Brasil, Bahia, Salvador $\backslash$ Paralela, $\backslash 12^{\circ} 58^{\prime} \mathrm{S} 38^{\circ} 26^{\prime} \mathrm{W} \backslash 31 \backslash 08 \backslash 2000 \backslash$ Batista, M.A. Leg' 'Bahia, Salvador\ Paralela (P1) Ess:5\ armadilha luminosa' 'UFBAl 04242' (19, UFBA); 'Brasil.BA\ Salvador\ Ondinal D.H. Smith\ 7.v.1986' '1026'

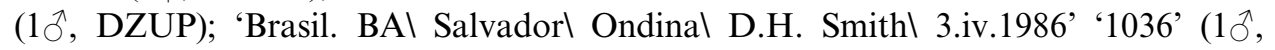
DZUP); 'Brasil.BAl Salvador\ Ondinal D.H. Smith\ 11.iv.1986' '1029' (19, DZUP); 'Brasil.BA\ Salvador\ Ondinal D.H. Smith\ 5.v.1986' '1024' (19, DZUP);

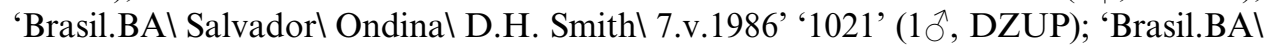

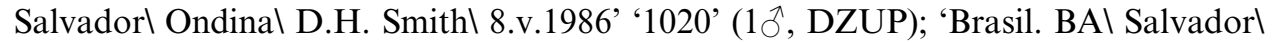
Ondina\ D.H. Smith\ 7.vi.1986' '1019' (19, DZUP); 'Brasil.BA\ Salvador\Ondinal D.H. Smith\17.vi.1986' '1018' (19, DZUP); 'Brasil.BA\ Salvador\ Ondinal D.H. Smith\22.vi.1986' '1025' (19, DZUP); 'BRASIL, BA\ Ondinal A. Raw coll 18. II.1984' (1ㅇ, DZUP); 'BRASIL, BA\ Ondinal A. Raw col 4.8 .85 ' (2ᄋ, DZUP);

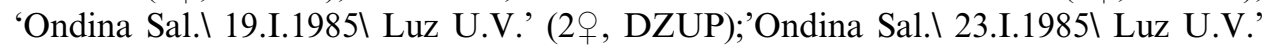

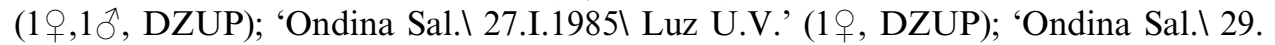

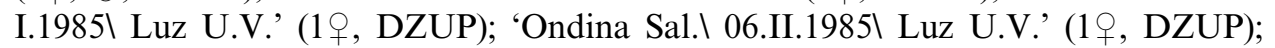
'Ondina Sal.\ 07.II.1985\ Luz U.V.' (19, DZUP); 'Ondina Sal.I 10.II.1985\Luz 
branca' (19, DZUP); 'Ondina Sal. 12.II.1985\ Luz U.V.' (19, DZUP); 'Ondina Sal.।

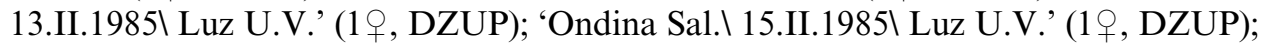

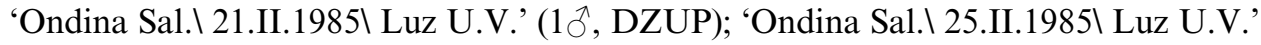

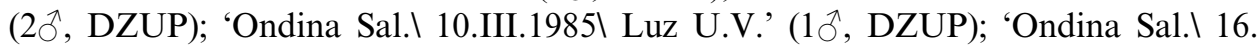

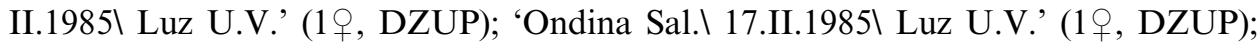

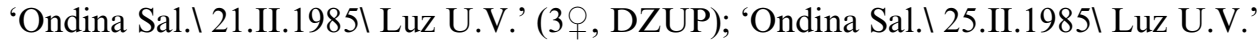
(19, DZUP); 'Ondina Sal.I 4.III.1985\ Luz U.V.' (19, DZUP); 'Ondina Sal.। 6.

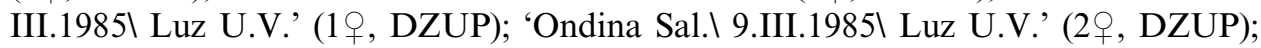

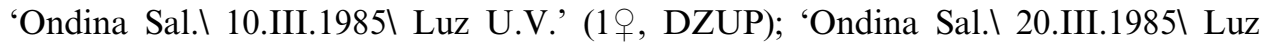

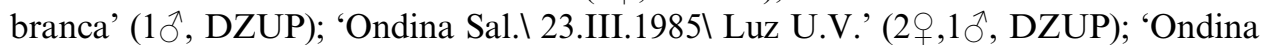

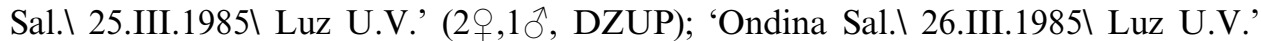

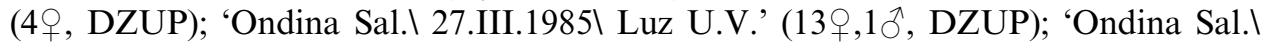

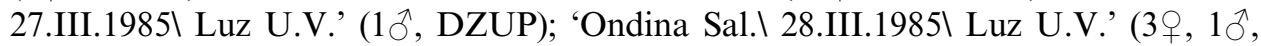

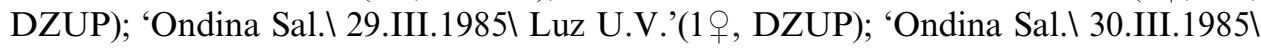
Luz U.V.'(1 9 , DZUP); 'Ondina Sal. 01. IV.1985 Luz branca' (3 9 , DZUP); 'Ondina

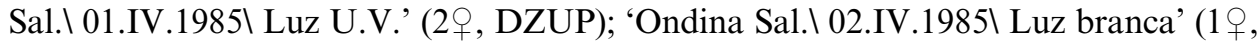

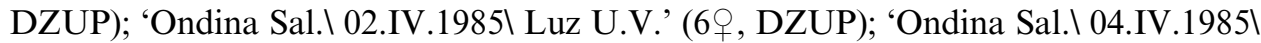
Luz U.V.' (5ᄋ, DZUP); 'Ondina Sal. $105 . I V .1985 \backslash$ Luz branca' (1ð̋, DZUP); 'Ondina

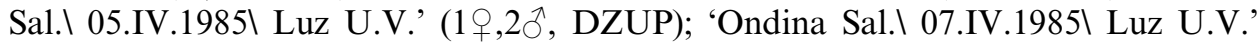
(2ㅇ, DZUP); 'Ondina Sal. 08.IV.1985 Luz branca' (1, DZUP); 'Ondina Sal. 08.

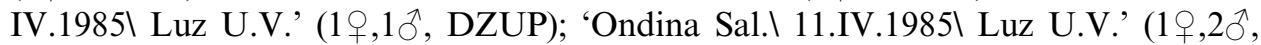

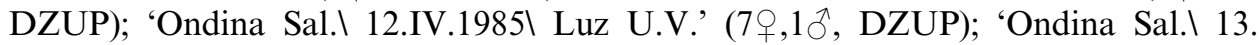

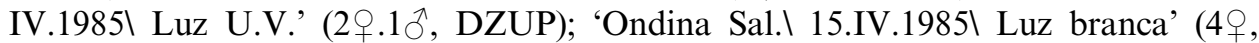

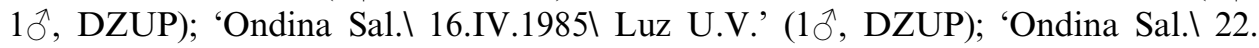

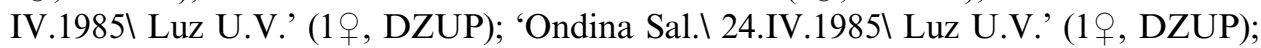

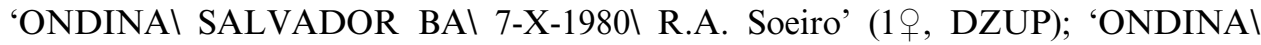
SALVADOR BA\ 9-X-1980\R.A. Soeiro' (19, DZUP); 'Salvador,Ba\ Brasill 5. V.1985 D.H. Smith' 'Armadilha\ Luminosal Luz branca' (1へ̂, DZUP); 'Salvador,

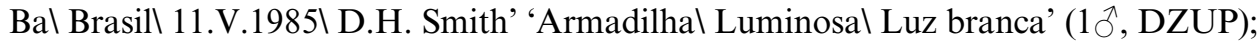
'Salvador,Ba\ Brasil\ 17.V.1985 D.H. Smith' 'Armadilha\ Luminosa\Luz branca' (1今̄, DZUP); 'Salvador,Ba\ Brasil $25 . V .1985 \backslash$ D.H. Smith' 'Armadilha\ Luminosal Luz branca' (1 $\odot$, DZUP); 'Salvador,Ba\ Brasil $\backslash$ 25.V.1985\ D.H. Smith' 'Armadilhal Luminosa\ Luz U.V.' (2 9 , DZUP); 'Salvador,Ba\ Brasil\ 4.VI.1985\ D.H. Smith' 'Armadilha\ Luminosal Luz U.V.' (1+, DZUP); 'Salvador,Ba\ Brasil 10.VI. 1985 D.H. Smith' 'Armadilha\ Luminosal Luz U.V.' (2ㅇ, DZUP); 'Salvador,Ba\ Brasill 11.VI.1985 D.H. Smith' 'Armadilhal Luminosal Luz branca' (19, DZUP); 'Salvador,Ba\ Brasil\ 12.VI.1985 D.H. Smith' 'Armadilha\Luminosa\ Luz branca' (19, DZUP); 'Salvador,Ba\ Brasil 1 13.VI.1985\ D.H. Smith' 'Armadilhal Luminosal Luz branca' (2q, DZUP); 'Salvador,Ba\ Brasil\ 16.VI.1985\ D.H. Smith' 'Armadilhal Luminosa\ Luz U.V.' (1 9 , DZUP); 'Salvador,Ba\ Brasil 16. VI.1985\ D.H. Smith'

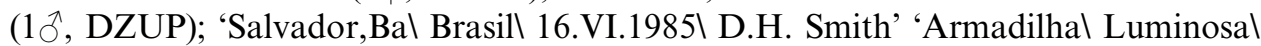
Luz branca' (1 9 , DZUP); 'Salvador,Ba\ Brasil\ 17.VI.1985 D.H. Smith' 'Armadilhal Luminosa\ Luz branca' (19, DZUP); 'Salvador,Ba\ Brasil\ 26.VI.1985 D.H. Smith’ 'Armadilha\ Luminosa\ Luz branca' (2ᄋ, DZUP); 'Salvador,Ba\ Brasil 27. VI.1985 D.H. Smith' 'Armadilha\ Luminosal Luz U.V.' (1+, DZUP); 'Salvador,Bal Brasill

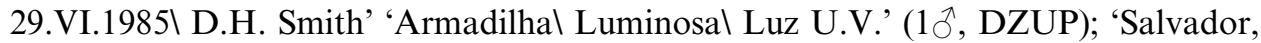
Ba\ Brasill 1.VII.1985\ D.H. Smith' 'Armadilhal Luminosal Luz branca' (1ळ’, DZUP); 'Salvador,Ba\ Brasil\ 2.VII.1985\ D.H. Smith' ‘Armadilha\ Luminosa\ Luz 
U.V.' (19, DZUP); 'Salvador,Ba\ Brasil\ 5.VII.1985\ D.H. Smith' 'Armadilhal Luminosa\ Luz U.V.' (2 9 , DZUP); 'Salvador,Ba\ Brasill 6.VII.1985\ D.H. Smith' 'Armadilha\ Luminosa\ Luz U.V.' (1 9 , DZUP); 'Salvador,Ba\ Brasil 7 .VII.1985 D. H. Smith' 'Armadilha\ Luminosal Luz U.V.' (19, DZUP); 'Salvador,Ba\ Brasill 9. VII.1985\ D.H. Smith' 'Armadilha\ Luminosa\ Luz U.V.' (2ㅇ, DZUP); 'Salvador,Ba\

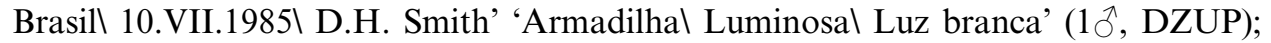
'Salvador,Ba\ Brasil\ 12.VII.1985\ D.H. Smith' 'Armadilha\ Luminosa\ Luz U.V.' (1 9 , DZUP); 'Salvador,Ba\ Brasil\ 12.VII.1985\ D.H. Smith' 'Armadilha\ Luminosal Luz branca' (19, DZUP); 'Salvador,Bal Brasill 14.VII.1985 D.H. Smith' 'Armadilhal Luminosal Luz U.V.' (2 9 , DZUP); 'Salvador, Ba.\ Brasil 27.IV.1985 D.H. Smith' 'Armadilha\ Luminosa\ Luz U.V' (19, DZUP); 'Salvador, Ba.I Brasill 29.IV.1985 D.H. Smith' 'Armadilha\ Luminosa\ Luz U.V' (19, DZUP); 'Salvador,

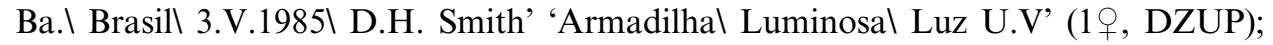
'Salvador, Ba.\ Brasil 3.V.1985\ D.H. Smith' 'Armadilha\ Luminosa\ Luz branca' (1今̂, DZUP); 'Salvador, Ba.\ Brasil\ 11.V.1985\ D.H. Smith' 'Armadilha\ Luminosal Luz branca' (19, DZUP); 'Brasil, BA, Senhor dol Bonfim, Serra Santana, $\backslash 10^{\circ}$

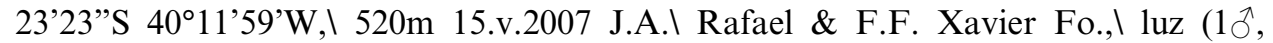
DZUP). Distrito Federal: 'Planaltina, DF\ BRASIL - 1000m\18.ix.1984\ V.O.

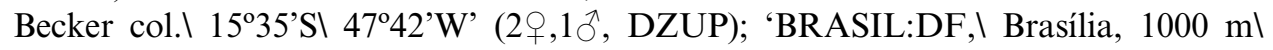
15.IX.1984\ V.O. Becker col.'(19, DZUP). Espírito Santo: 'Brasil, Espírito Santol Conceição da Barral xi.1985.C. Elias leg.' (3ð̉, DZUP). Goiás: 'Faz. Nova Orlândial Jataí, Go- Brasil\ I.1964 - Martins, \Morgante \& Silva. (2q, MZUSP); 'Brasil, Goiás, Chapada dos $\backslash$ Veadeiros, Vale Dourado, $\backslash 14^{\circ} 11^{\prime} \mathrm{S} 47^{\circ} 37^{\prime} \mathrm{W}, 1100 \mathrm{~m}, \backslash 31 . i i i . .2003$, 6h, Melol Aguiar\ Marchi e Gonçalves\ em Lamiaceae' (1+, DZUP); 'Brasil, Goiás, Chapada dos $\backslash$ Veadeiros, Vale Dourado, $\backslash 14^{\circ} 11^{\prime} \mathrm{S} 47^{\circ} 37^{\prime} \mathrm{W}, 1100 \mathrm{~m}, \backslash 01 . i v .2003$, 6h, Melo\ Aguiar\ Marchi e Gonçalves' (2+, DZUP). Mato Grosso: ‘ Alto Araguaia MT\ Córrego da Vacal Brasil, 04.03.2010 A. Santos leg. '44095 UFPE' 'Acetato de Metila' Megalopta sp.6\ A1498\AT Carvalho det.2010' (1ㅇ, DZMG); 'BR-29 RIO JURUENA\M. Grosso Brasil XI-1960\M. Alvarenga leg' (19, DZUP); 'MATO GROSSO Barra das Garças 18-4-1978\ coll. A. Raw' (1仓̄, DZUP); 'Brasil MT\ Chap. dos Guimarães\Colégio Agr. Buriti\} 1 3 \text { a 17-II-1986\Col. I.S. Gorayeb' } 'Armadlhal 1,6m\ Suspensa' (1+, DZUP); 'BRASIL: Mato Grossol Reserva Humboldt $10^{\circ} 11^{\prime} \mathrm{S} 59^{\circ} 48^{\prime} \mathrm{W} \backslash$ VII-13-19-1977\ B.C. Ratcliffe' (19, DZUP); 'DPT'ZOOLI UF-PARANÁ' 'JACARÉ-P.N. Xingul M. Grosso - BRASIL\ 25/30/ 11/1965 M. Alvarenga leg' (1ठ, DZUP); 'Brasil, Mato Grosso, $\backslash 18 \mathrm{~km} \mathrm{~W} \mathrm{de} \mathrm{Noval}$ Mutum Faz. Buritil 12.I.2000, HF Mendes' (1+, DZUP); 'MT Aripuanã \ Resv. Humbolt $\backslash$ março 1977' 'Brasil Parál WL Overal' 'Megalopta sp $\backslash$ Det Camargo. 82' (1 $\odot$, MPEG). Mato Grosso do Sul: 'M. Grossol Bataguaçu\ Rabello\ 7-x-1954'(1 MZUSP); 'BRASIL, Mato Grosso do Sul, \Bonito, Fazenda Pitangueiras, \3.iii.2009, 2052'S 56³5'W 479m,LUZ, J.C. Gaona, leg.' (19, DZUP); 'BRASIL, Mato Grosso do Sul, $\backslash$ Bonito, Serra da Bodoquena,\Fazenda Pitangueiras, 4.iii.2009, $\backslash 20^{\circ}$ 48’S 56³7’23’W, $535 \mathrm{~m}$, LUZ, J.C. Gaona, leg.' (19, DZUP). Maranhão: '22-X-2001 SERRA DO $\backslash$ PENITENTE, BALSAS $\backslash$ MA, 600M $\backslash$ C. MIELKE LEG' (1 9 , DZUP); 'Brasil, Maranhão, \Serra do Penitente,\01-02.xi.2002, C. Mielke' (5๑,1ð̄, DZUP);

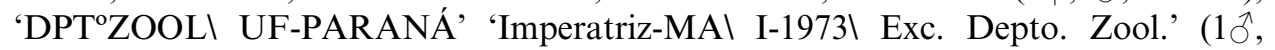

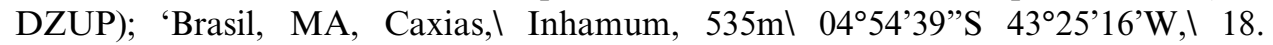
v.2007, J. Rafael, F.I Xavier Fo \& F. Oliveira,\luz' (1 $\partial^{\top}$, DZUP); 'Brasil, MA,

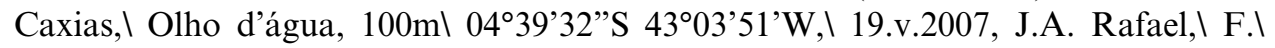


Xavier Fo \& F.L.I Oliveira, luz' (19, DZUP). Minas Gerais:'5-8-XII-2002\ PETI, SÃO GONÇALO RIO ABAIXO, MG, 560m\MIELKE LEG' (1ㅇ, DZUP); 'P.F. E.R.D. MG LOCAL_\DATA:13-15/XII/1977' 'Pe' (1ठ̃, DZUP); 'P.F.E.R.D. MG\LOCAL_I DATA:13-17/XII/1977' 'Pe' (19, DZUP); 'BRASIL, MG,

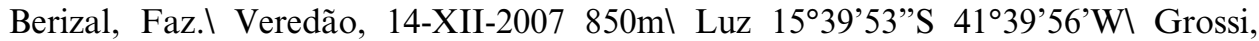
Rafael \& Parizotto' (2, DZUP);'Brasil, Minas Gerais, $13 \mathrm{Km}, \backslash \mathrm{NE}$ de Ipanema, Fazendal Montes Claros, 400m\29.-i-30.i.2003 Mielke \&l Casagande, armadilhal

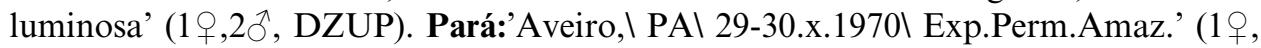
MZUSP); 'Brasil Pará \Acará IIha de Combú 30. VIII.1989' 'Brasil Pará R.B Neto' (1つ̂, MPEG); 'Brasil Parál Acarál Ilha de Combúl 31.VIII.1989' 'Brasil Parál R.B Neto' (29, MPEG); 'Brasil Parál Alenquer\ 2 julho 1979' 'Brasil Parál W França' (14ㅇ, 9ð, MPEG); 'Brasil Pará Alenquer 2 julho 1979' 'Brasil Parál P Tadeu' (4웅,

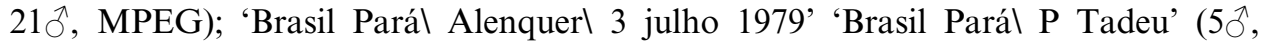
MPEG); 'Brasil Parál Alenquerl 3 julho 1979' 'Brasil Parál W França' (3ð̂, MPEG); 'Brasil Parál Alenquerl 4 julho 1979' 'Brasil Parál W França' (20̂, MPEG); 'Brasil Pará Alenquer 5 julho 1979' 'Brasil Parál P Tadeu' (19, MPEG); 'PA:BR-14 km 93\ Belém-Brasília\ Ago-out.1959\ Exp.Dep.Zool.' (19, MZUSP); 'bôca do Cuminá-Miril Oriximiná, PAl 19-26.I.1968। Exp. Perm. Amaz.' (1ô, MZUSP); 'BRASIL\Pará Belém\Floresta APEG\27-XI a 2-XII-83' 'I.S. Gorayeb\ Armadilha\1,6m\Suspensa' (1\%, INPA); 'BRASIL, PA, Belo Monte, \ Rio Xingu,

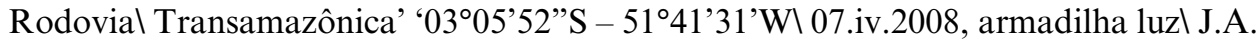
Rafael \& F.F. Xavier $\mathrm{F}^{\circ}$ ' (2 $\mathrm{o}^{\wedge}$, INPA); 'BRASIL, PA, Belterral FLONA Tapajós, $100 \mathrm{~m} \backslash 02^{\circ} 36^{\prime} 15^{\prime}$ 'S - 54 ${ }^{\circ} 56^{\prime} 35^{\prime} \mathrm{W}^{\prime}$ ' 15-16.iv.2008, arm. luz J.A. Rafael \& F.F. Xavier

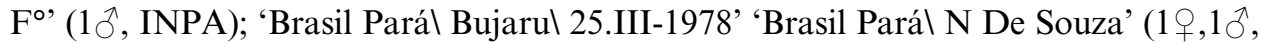
MPEG); 'Brasil Parál Bujarul 26.III-1978' 'Brasil Parál M F Torres' (19, MPEG); 'Cach. do Itacél 7.8.' 'Brasil, PA/AP\ Rio Jari, 1961\ Dr. W. Egler' 'Megalopta sp $\backslash$ Det. Camargo. 82' (19, MPEG); 'CACHIMBO\ Pará BRASIL\ X-1959 M. Alvarenga' (19, MPEG); 'BRASIL:PA\Capitão Poço\19-22.xi.1984\ V.O. Becker

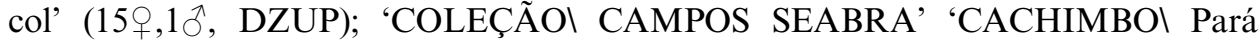

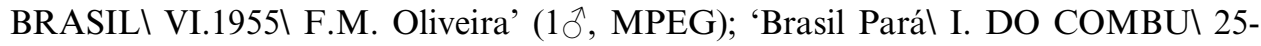
X-1989\ R.B. NETO' 'Hymenoptera: Apocrital Aculeata: Apoideal Halictidael Incorporação 7.VI.1999' (19, MPEG); 'Brasil Parál Maracanãl Ilha do Marcol 11a13.I.1993' 'Brasil Parál J. Dias' (1ðત, MPEG); 'BRASIL, PA, Medicilândial Rod. Transamazônical $03^{\circ} 26^{\prime} 45^{\prime}$ 'S - 52 $56^{\circ} 12^{\prime} \mathrm{W}^{\prime}$ '09.iv.2008, arm. luzl J.A. Rafael

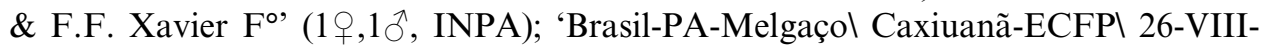
1995। R.M. Valente col.' 'Isca humanal Torre 22m' 'Hymenoptera: Apocrital Aculeata: $\backslash$ Apoidea: $\backslash$ Apidae:\Incorporação 17.VII.2002' (1+, MPEG); 'Peixe-Boil 20.211964' 'Brasil, PAl W. França Col.' 'Megalopta $s p \backslash$ Det. Camargo. 82' (1ð̄, MPEG); 'Brasil Parál Primaveral Boa Vistal Ilha Aropirangal 22.XI.1992' 'Armadilha\ de Luz' (10̄, MPEG); 'BRASIL:Pará Riol Poana a direital Subindo 6X-85 Eq. Comander' (1 9 , INPA); 'BRASIL:Parál Rio Trombetas Est.l da Fumaca 02-X-85\ Eq. Comander' (1 9 , INPA); 'Brasil Pará \São João de Pirabas \Japerica\ 16a18.XII.1992' 'Brasil Parál J. Dias' 'Armadilhal Malaise (1+, MPEG); 'Brasil Pará \ão João de Pirabas\ Japerical Ilha Conceiçãol 20.XII.1992' 'Brasil Parál J. Dias' 'Armadilhal de Luz (4ㅇ, 1ठ, MPEG); 'Brasil Parál São João de Pirabas। Japerical 18.XII.1992' 'Brasil Parál J. Dias' (1ð̄, MPEG); 'Brasil Parál Serra Nortel No1 MATAl 25a28.x.1985' 'Armadilhal 1,6m\ Suspensa' 'Brasil Parál J. Dias' 'MPEG-HYM\ 11005602' (19, MPEG); 'Brasil Parál Serra Nortel 
Estra-LIXEIRAI COL: NOTURNAI 31-X-1985' 'Brasil Parál N. Bittencourt' 'MPEG-HYM\11005610' (19, MPEG); 'Brasil Parál Serra Nortel CALDEIRÃO\} COL. NOTURNAI 25-X-1985' 'Brasil Parál R.B. Neto' 'MPEG-HYM\11005612' (1̧̄, MPEG); 'Brasil Parál Serra Nortel PARAUAPEBAS $\backslash$ COL: NOTURNA\ 7XI-1985' 'Brasil Parál J. Dias' 'MPEG-HYM\11005614' (1ð̋, MPEG); 'Brasil, Parál Serra Nortel Est. MANGÂNES $\backslash$ ARM. SUSPENSA\ 12-06-1983\ Col. W. França' 'MPEG HYM\ 11004786' (1ð̊, MPEG); '5598' 'BRASIL:Parál TucuruíREMANSÃO\03-VIII-1980 eq. Nunes de Mello' (1요 INPA); '5614' 'BRASIL: Parál Tucuruí- BAGAGEM $\backslash$ 06-VIII-1980\ eq. Nunes de Mello’ (2o, INPA); 'Brasil Pará Tucuruíl Rio Tocantis\ ARM-LUZI 01.VIII.1984' 'Brasil Parál B. Mascarenhas' (1亏̄, MPEG); 'Brasil Pará Tucuruíl Rio Tocantis\ canoall 02. III.1984' 'Brasil Parál W. França' (10̄, MPEG); 'Brasil Parál Vigial CAMPINA\ 7-

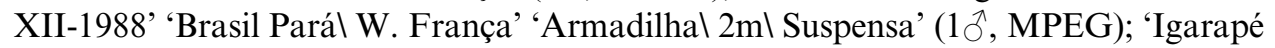
Gurupi-Umal Aldeia Araçu - MA\} 5 0 \text { km E de Canindél V.1963, Malkin col.' (1ð̂, } MZUSP). Paraíba: 'BIOTA-FAPESP\ BRASIL-PB-João Pessoal Mata do Buraquinhol $7^{\circ} 08^{\prime} 25^{\prime \prime S} 34^{\circ} 51^{\prime} 38^{\prime} \mathrm{W} \backslash$ Armadilha Malaise-bosque, pto3\ 25-28. vii.2002\ STP,Amarante \& eq.col.' 'BIOTA Abelhasl 0013' (19, MZUSP); 'MAMANGUAPE PB\Res. Biol. Guaribas\ Brasil 1.11.1999\R. Oliveira leg.' '2984 UFPE' 'L93 P904\ 18:00 s/n pousando nas pétalas? Hancornia speciosa'

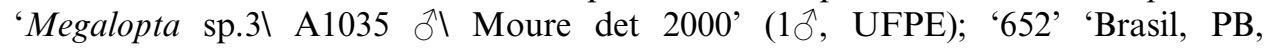

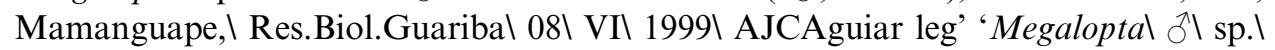
F.A. Silveira, det,2000' (1ડ̄, UFCE); '1123' 'Brasil, PB, Mamanguape,। Res.Biol.

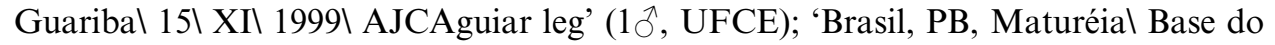
Pico do Jabrel 4.i.2003 F-Zanellal B1 A1 Orif. 15-12mm' 'LEBICl 01180' (1今,, LEBIC). Pernambuco: 'Camaragibe PE\ Aldeia\ Brasil 15.05.2006\ Schlindwein leg' 'L120\sem planta' '36876 UFPE' 36878 UFPE' (29, DZMG); 'Camaragibe PE\ Aldeia Canãa\ Brasil 25.05.2002\ C. Schlindwein leg' 'L120' ‘40796 (1ðð, DZMG); 'IGARASSU PE\ Usi. São José (Piedade)\ Brasil, 9.11.2007\ A. Maia' ‘44499 UFPE' 'L121' (19, DZMG). Rio Grande do Norte:'Brasil, RN, Baia Formosa,। Mata Estrela, 44m, $\backslash 06^{\circ} 23^{\prime} 19^{\prime}$ 'S $35^{\circ} 01^{\prime} 05^{\prime} \mathrm{W}, \backslash 24 . v .2007$, J.A. Rafael \&\ F.F. Xavier Fo.,

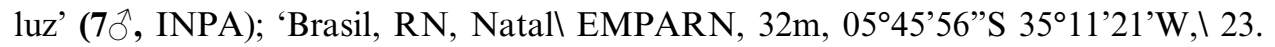
v.2007, J. Rafael \& F. Xavier Fo. luz' (1今̄, DZUP). Rio de Janeiro: 'BIOTAFAPESP' 'BRASIL: RJ: Nova Igaçul Res. Biol. do Tinguál 22³4'35”'S 43 26'10'W \ Varredura amostra 14\ 8.iii.2002 $\backslash$ ST P Amarante \& eq. col' 'BIOTA Abelhas $\backslash 0011$ ' (1̧̄, MZUSP); 'BOTAFOGO Distrito Federal BRASIL\IX.1958। L.C. Alvarenga' (1§̄, DZUP); 'Brasil, RJ, Macaé,\PN Jurubatiba, Restinga, $\backslash 22^{\circ}$

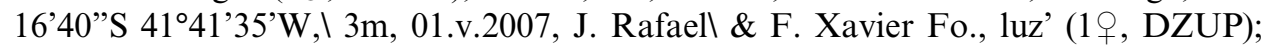
'Brasil, Rio de Janeiro,। Rio de Janeirol 30.xii.2008, D.M. Takiya' (1ڤ̄, DZUP); 'COLEÇÃO\ CAMPOS SEABRA' 'FLORESTA DA TIJUCAI D. Federal BRASILI 11 Março $1958 \backslash$ C.A. Campos Seabra' (19, DZUP); 'COLEÇÃO। CAMPOS SEABRA' 'REPRESSA RIO GRANDEI Guanabara-Brasill 18-XI$1960 \backslash$ F.M. Oliveira' (2ᄋ， DZUP); 'COLEÇÃO। CAMPOS SEABRA' 'REPRESSA RIO GRANDE\ Guanabara Brasil\ Dezembro 1960\F.M. Oliveira' (18, DZUP); 'REPRESSA RIO GRANDE\ Guanabara Brasil $\backslash$ Dezembro 1960\F. M. Oliveira' (1q, DZUP). Rondônia: 'Brasil, RO, Itapuã $\backslash$ do Oeste, Flonal do Jamari, $110 \mathrm{ml} 9.260^{\circ} \mathrm{S} 62.913^{\circ} \mathrm{W} \backslash 4 . i x .2012$, Cavichiolil Melo, Rosa \& Santos' 'Armadilha\ Luminosa' (1 + , $1 \delta^{\Uparrow}$ DZUP); 'Brasil, RO, Itapuã $\backslash$ do Oeste, Flonal do Jamari, $90 \mathrm{~m} \backslash 9.146^{\circ} \mathrm{S} 63.012^{\circ} \mathrm{W} \backslash$ 5.ix.2012, Cavichiolil Melo, Rosa \& Santos' 
'Armadilha\ Luminosa' (11ㅇ, 1ठǱUP). 'BRASIL: Rondônia\ Ji-Paranál 14-18-II$1983 \backslash$ equipe J.R. Arias (19, INPA)'; 'BRASIL: RO \Porto Velho, 180m\24-30. iv.1989\ V.O. Becker' (19, DZUP); 'BRASIL: RO\ Porto Velho, 180m\2-12.v.1989 V.O. Becker' (3ㅇ, DZUP); 'Brasil, Rondônial Ouro Preto do Oestel LINHA 212 LOTE 36\ GLEBA 21-B \1a3.IX.1986' 'Armadilha \1,6m\ Suspensa' 'Brasil, Rondônia\ F.F. Ramos' (19, DZUP); '2534' 'T. Fed. Rondônial Em 11/9/63\ ColEduardo' (1, INPA); 'T. Guaporél C. Sãmuel\ Rio Jamary\155.911 Park' 'argoides\ (Vach.)' '(verso: M.N. Paris $\backslash$ C.W.T.I M... 28-58' 'Plaquetal preespiracular' (1ठิ, DZUP); Roraima: Brasil, Roraima, Amapari, $\backslash$ Tepequém, Trilha Iguarapé da Anta $03^{\circ} 47^{\prime} 00,5^{\circ} \mathrm{N} 61^{\prime}$ ' $445^{\prime} 49,8^{\circ} \mathrm{W}$ 603m 15-abr-09\16:00 Grigio, Jr.O Eugenol' 'MIRR 11899' (19, MIRR);'Brasil, Roraima, Amapari,I Tepequém, Trilha Iguarapél da Anta $03^{\circ} 46^{\prime} 19,7^{\circ} \mathrm{N}$ ' ' $61^{\circ} 45^{\prime} 21,6^{\circ} \mathrm{W}$ 649m 14-I mai-09 11:00 Grigio, Jr..O $\backslash$ Salicilato' 'MIRR 12679' (1+, MIRR);'IDEM' 'MIRR 12680' (1+, MIRR); 'IDEM' 'MIRR

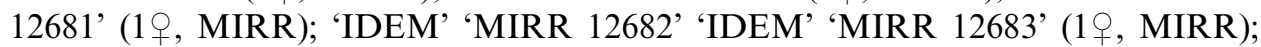
'IDEM' 'MIRR 12684' (1+, MIRR);'IDEM' 'MIRR 12688' (1+, MIRR); 'IDEM' 'MIRR 12691' (19, MIRR); 'IDEM' 'MIRR 12692' (19, MIRR); 'IDEM' 'MIRR 12693' (1q, MIRR); 'IDEM' 'MIRR 12694' (1ㅇ, MIRR); 'IDEM' 'MIRR 126966' (19, MIRR); 'IDEM' 'MIRR 12697' (19, MIRR); 'IDEM' 'MIRR 12698' (1q, MIRR); 'IDEM' 'MIRR 12699' (1+, MIRR); 'IDEM' 'MIRR 12700' (1ㅇ, MIRR); 'IDEM' 'MIRR 12701' (1+9, MIRR); Brasil, Roraima, Amapari,l Tepequém, Trilha Iguarapél da Anta $03^{\circ} 46^{\prime} 06,8^{\circ} \mathrm{N} 61^{\circ} 45^{\prime} 33,7^{\circ} \mathrm{W}$ ' $625 \mathrm{~m}$ 14-mai-09 10:00\ Grigio, Jr. O.I Eugenol' 'MIRR 12522' (1ㅇ, MIRR); 'Brasil, Roraima, Amapari,। Tepequém, Trilha Iguarapél da Anta $03^{\circ} 46^{\prime} 06,8^{\circ} \mathrm{N} 61^{\circ} 45^{\prime} 33,7^{\circ} \mathrm{W}$ ' ' $625 \mathrm{~m}$ 29-set-09 14:40 Silval S.J.R, da \& Grigio, Jr.O.I Eugenol' 'MIRR 13086' (1 , $^{\circ}$ MIRR);Brasil, Roraima, Amapari, $\backslash$ Tepequém, Trilha Iguarapél da Anta $03^{\circ}$ 46 ' $19,7^{\circ} \mathrm{N}$ ' ' $61^{\circ} 45^{\prime} 21,6^{\circ} \mathrm{W} 649 \mathrm{ml} 14 \backslash$-mai-09 14:00 Grigio, Jr.Ol Eugenol' 'MIRR 12758' (19, MIRR); 'Brasil, Roraima, Amapari,\ Tepequém, Igarapé do Melo $03^{\circ}$

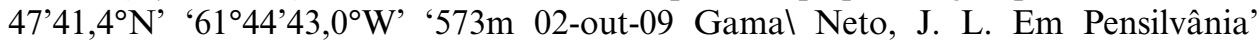
'MIRR 13295' (1q, MIRR); 'IDEM' 'MIRR 13304' (19, MIRR); 'IDEM' 'MIRR 13305' (19, MIRR); 'Brasil, Roraima, Amapari,\ Tepequém, Igarapé do Melo\03 $47^{\prime} 41,4^{\circ} \mathrm{N}$ ' ‘ $61^{\circ} 44^{\prime} 43,0^{\circ} \mathrm{W}$ ' '573m 14-mai-09 09:00\ Griggio, Jr. O. Salicilato' 'MIRR 12458' (19, MIRR); 'Brasil, Roraima, Amapari,\ Tepequém, Mata Margem\ da Estrada $03^{\circ} 44^{\prime} 51,0$ ” N '6143’36,4’W 612m 16-I abr-09 7:30h Grigio, Jr. O.I Salicilato' 'MIRR 12369' (19, MIRR); 'Brasil, Roraima, Pacaraima,। Ramal do Miang $04^{\circ} \backslash 29^{\prime} 37^{\prime \prime} \mathrm{N} 61^{\circ} 04^{\prime} 35^{\prime} \mathrm{W}$ 770m' '10-jul-08 Silva,S.J.R. da Silva Em\ isca aromática' 'MIRR 10295' (1+, MIRR); 'IDEM' 'MIRR 10300-10302' (3ㅇ, MIRR); 'Brasil, Roraimal Tepequém\ Pousada SESCl 0345'186”N N 6142'959'W' ‘637 m 14/viii/2009\ M.L. Oliveira, O.\ Mielke \& M.\ Casagrande leg.' (19, INPA); 'Brasil, RR, Guaporél 12¹6’05”S $\backslash 60^{\circ} 42^{\prime} 30^{\prime} \mathrm{W} \backslash$ 23.IV.2006 LUZ\ J.A. Rafael leg.' (2+, CPDP); 'Vista Alegrel Rio Brancol Amazonas\ 5.IX.14' 'idalia\ Sm\ Det. J.S. Moure 19' '(verso:Br. M. N. Hist.I C.W.T.I 17a 1276)' (1q, DZUP); 'Brasil:

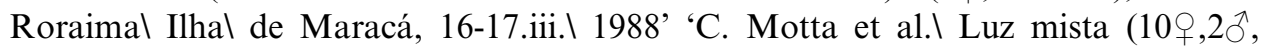
INPA); 'Brasil: Roraima\ Rio Uraricoera\ Ilha de Maracál 02-13-v-1987' 'Eq. J.A. Rafaell Arm.de Malaise' (19, INPA); 'Brasil: Roraimal Rio Uraricoeral Ilha de Maracál 18-29-vii-1987' 'J.A. Rafaell L.S. Aquinol J.F. Vidall Elias Binda' 'Armadilhal de Luz' (19, INPA); 'Brasil: Roraimal Rio Uraricoeral Ilha de Maracá' '21-30-xi-1987\ J.A. Rafael el equipe (1요 INPA); 'Brasil: Roraimal Rio Uraricoera\ Ilha de Maracá $02-13-v-1987$ 'J.A. Rafael $\backslash$ J.E.B. Brasill L.S. Aquino' 
'Armadilhal de Malaise' (4ㅇ,1 $\hat{\jmath}$, INPA). Sergipe: 'BIOTA-FAPESP $\backslash$ Brasil:SE, Santa Luzia do Itanhy $\backslash$ Crasto, $11^{\circ} 22^{\prime} 43,9^{\prime}$ 'S 37 $25^{\prime} 03,0^{\prime} \mathrm{W} \backslash$ Varredura, amostra $19 \backslash$ 01. viii.2001\MT Tavares e eq. col.' 'BIOTA Abelhas $\backslash 0012$ ' 'sp2'(1ठ, MZUSP). São

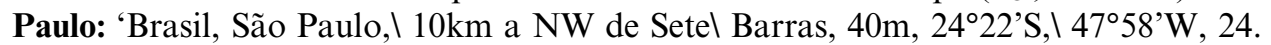
xii.2004-8.i.2005, arm. malaise' (1 , DZUP); 'Brasil, São Paulo, $\ 35 \mathrm{~km}$ a NE de Miracatu, \550m, 12.ix.2005,\ Mielke \& Casagrande' (1+, DZUP); 'Brasil, São Paulo, $\backslash 43 \mathrm{~km}$ a NE del Miracatu,8-9.x.। 2005, O. Mielke' (3ㅇ, DZUP); 'Brasil, São Paulo, $10 \backslash \mathrm{km}$ a NW de Sete $\backslash$ Barras, 40m, 2422'S, $\backslash 47^{\circ} 58^{\prime} \mathrm{W}, 26 . i i i .2005$, \ armadilha luminosa' (1ठ̄, DZUP); 'Caraguatuba-SP\(Res. Flor.-40m.)\22.V.- I.VI.1962\ Exp. Dep. Zool.' 'Ninho' (2ᄋ, DZUP); 'Cerrado-Est.Ecol.Jataí-SP.I BR 20.x.1992 no $2300 \backslash$ h:18:39, Mateus,S. Leg.। Fora area' (1ㅇ, DZUP); 'Faz. Itaquerê,। Nova Europa, SP.\ 14-VIII.1963\K. Lenko col.' 'A Luz' (19, MZUSP); 'Ilha Bela\ I.S. Sebastiãol SP v.1981\ Brandão col.' (1へ̂,, MZUSP). Tocantis: 'BRASIL, TO,

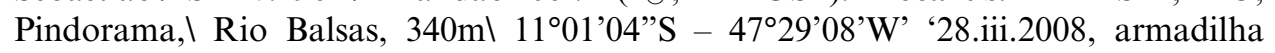

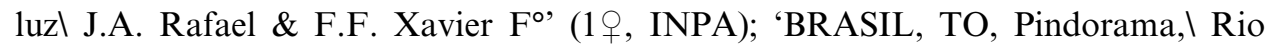

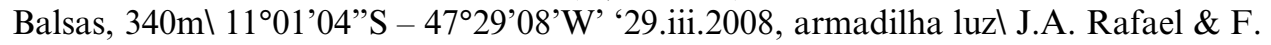
F. Xavier $F^{\circ}$ ( 1 , , INPA). GUYANA: ' Museum Leiden\ BRITISH GUYANAI Mackenziel 17-19.III.1966\J. Geijskes' (1q, RMNH). NICARAGUA: Masaya: 'NICA: Managua:\Ticuantepe:\Casa Blancal 30-IV/1-V-2001.I col. J.M. Maes, J. Sunyer $\&$ B. Hernandez' (1 9 , DZUP). PERU: Loreto: 'Peru, LO $\backslash$ A\&E Tours, frog

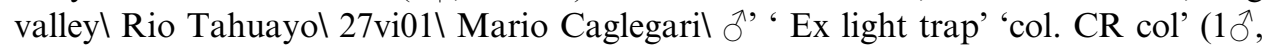
CRC). SURINAME: Brokopondo: 'Museum Leiden\SURINAM\ Brokopondol VI.1964\ M. Boeseman' (1q, RMNH). Paramaribo: 'Surinamel Paramaribol Ma Retraitel20-23.1964\ D.C. Geijskes' 'MALAISE TRAP' (2ᄋ, RMNH). Sipaliwini: 'Museum Leiden\SURINAM $\backslash$ Sipaliwini $\backslash$ 20-31.I.1968\G.P. Mees' (1 9 , RMNH); 'Surinamel Upper Corantijn RiverlCoeroenil 19 June 1963\ J.G. Wessels Boer' 'AIRSTRIP' 'at light' (19, RMNH); 'Surinamel Upper Corantijn RiverlCoeroenil 21 aug 1969' 'Leg. D.C. Geijskes' (1 9 , RMNH); 'Surinamel Republiek\ 8-12 oct \1963\ D.C. Geijskes' ' MALAISE TRAP' (1ㅇ, RMNH). TRINIDAD AND TOBAGO: Tunapuna/Piarco: 'TRINIDAD\ Curepe (CIBC)\14-21.iv.1987\ Mal. trap RMNH $\backslash$ N.v.Buren' (1 $\curvearrowright$, RMNH). VENEZUELA: Miranda: Curupao.

\section{Megalopta chaperi}

BRAZIL. Roraima:'BRASIL: Roraima, Ilhal de Maracá,16-17.iii.1988. C. Motta et. al.\ Luz mista' (2 , INPA); 'BRASIL: Roraima, Ilhal de Maracá, 20-21.iii.1988. C. Motta et. al. $\$ Luz mista' (2q, 2へ, INPA); 'BRASIL - Roraimal Rio Uraricoera\ Ilha de Maracál 02-13.v.1987' 'J.A. Rafael\ J.E.B. Brasil\ L.S. Aquino' ‘Armadilhal de Malaise' (1q, INPA); 'Brasil, Roraima, Amajari\ Tepequém Trilha Igarapél da Anta 0346'19.7”N' ‘6145'21.6’W 649m 14-I mai-09 11:00 Grigio, Jr.O Salicilato' 'MIRR 12677 ' (1 q, MIRR); 'BR RR Uiramutã, Rio Wailã 043750/600946\22/III/2007\ F.F. Xavier Filho, col.। Luz Mista Mercúrio (2甲, INPA).

\section{Megalopta guimaraesi}

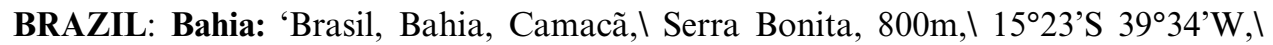
=14.i.207, G. Melo, \atraídas por luz,4-5:00' (4ㅇ, DZUP); '25-30-I-2007 RIO DE CONTAS, BAHIA $1900 \mathrm{~m}$, MIELKE \&I CASAGRANDE LEG.' (1 $q$, DZUP). 
Distrito Federal: 'BRASIL: DF $\backslash$ Brasília, 1000m\15.IX.1984\ V.O. Becker col.' (1ठ઼, DZUP); ' $15^{\circ} 35^{\prime} \mathrm{S} \backslash 47^{\circ} 42^{\prime} \mathrm{W} \backslash$ Planaltina, DF, $\mathrm{BRASIL}$ - 1000m\18.IX.1984\ V.O. Becker col.' (4, DZUP); 'Coleçãol EMBRAPA-CPACl No10536' '1535'S $47^{\circ}$

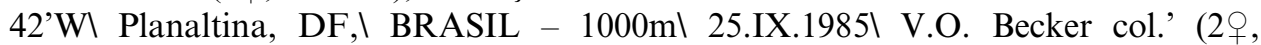
DZUP); 'Coleçãol EMBRAPA-CPACl No10537' '15³5'S $47^{\circ} 42^{\prime} \mathrm{W} \backslash$ Planaltina,

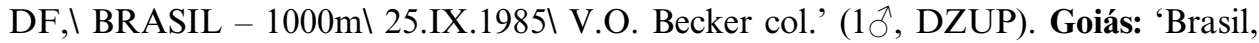
GO, Caldas $\backslash$ Novas, PE Serra del Caldas Novas, 700-1000m' '1746'13”S - 48

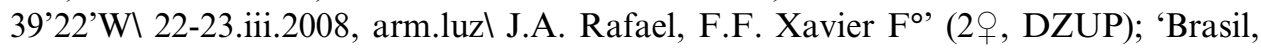
Goiás, Chapada dos\ Veadeiros, Vale Dourado, $\backslash 14^{\circ} 11^{\prime} \mathrm{S} 47^{\circ} 37^{\prime} \mathrm{W}, 1200 \mathrm{~m}, \backslash 31$. iii.2003, 6h, Melo,\ Aguiar, Marchi e Gonçalves\ em Lamiaceae' (1 $\jmath^{\lambda}$, DZUP); 'Brasil, Goiás, Chapada dos $\backslash$ Veadeiros, Vale Dourado, $\backslash 14^{\circ} 11^{\prime} \mathrm{S} 47^{\circ} 37^{\prime} \mathrm{W}, 1100 \mathrm{~m}, 1$ 01.iv.2003, 6h, Melo, Aguiar,\Marchi e Gonçalves' (5, DZUP); 'Formosa, Goiás\ BRASIL - 800m\22.IX.1984\V.O. Becker col.' (1§̋, DZUP); 'Faz. Nova Orlândial Jataí,Goiás-Brasill X.1962\ Exp. Dep. Zool.' 'À luz' (1ðð, MZUSP); 'Faz. Nova Orlândial Jataí,Go-Brasill I.964- Martins, Morgane \& Silva.' 'À luz' $(2 \circ, 10$, MZUSP). Maranhão: 'Brasil (MA), Caxias\ Balneário Shalom\ Armadilha Luminosa,\27-28.ii.2004, F. Limeiral -de-Oliveira et al cols.' (1옹 INPA); 'Brasil (MA), Acailândial Faz.Itabaiana, Arm. Luís de Queiroz, 14-15.iv.l 2001, J.T. Câmara. (1ㅇ, INPA); '22-X-2001 SERRA DO\ PENITENTE, BALSAS\MA, 500m\C. MIELKE LEG.' (1q, DZUP); 'Brasil, Maranhão,\Serra do Penitente,। 01-02.xi.2002, C. Mielke' (1 9 , DZUP); 'Brasil,MA, Caxias, \Olho d'água, 100m, $\backslash 04^{\circ}$ 39'32”S 4303'51'W, \19.V.2007, J.A. Rafael, \F. F. Xavier Fo. \& F.L.I Oliveira, luz' (1 9 , DZUP). Mato Grosso: 'Alto Araguaia MT $\backslash$ Ribeirão Claro\ Brasil 04.03.2010 A.T. Carvalho, leg.' '61671UFPE' 'Luzl Acetato de Metila' 'Megalopta sp.91 A15011 AT Carvalho det. 2010' (1 9 , DZMG). Mato Grosso do Sul: 'BRASIL-MS $\backslash$ COSTA RICA 17-XII-93\ S.IDE- COL.' (1 q, DZUP). Minas Gerais: 'Brasil, Minas Gerais,। Corinto, 16-31.xii.1979, C\Elias leg' (10̂, DZUP); 'Entomofauna dol Pq. E. Rio Docel 12758-37184' 'Marliéria MG BRASIL 20/10/1980\ Monteiro \& Mascarenhas' (19, DZMG); 'Entomofauna dol Pq. E. Rio Docel 12758-37245' 'Marliéria MG। BRASIL 20/10/1980\ Monteiro \& Mascarenhas' (19, DZMG); 'Entomofauna dol Pq. E. Rio Docel 12758-37246' 'Marliéria MG\ BRASIL 20/10/1980 Monteiro \& Mascarenhas' (19, DZMG); 'Entomofauna dol Pq. E. Rio Docel 12758-37247' 'Marliéria MG\BRASIL 20/10/1980\ Monteiro \& Mascarenhas' (19, DZMG); 'Abelhas Noturnas\ EPDA de Petil 11964-35500' 'S. Gonçalo R. Abaixo MGl BRASIL 23/02/2005\R.B. Martines' (19, DZMG); 'Viçosa, MG, Brasil\ Data 8/ 10/1988\ P.S. Fiuza F.' 'Córrego do Paraísol Mata da Prefeitural Armadilha UV' (1q, MEUFV). Parana: 'Brasi, Paraná, Campol Mourão, Reserva Lagoa Azul, 24 05’27’S 52¹9’55’W,\09.x.2010, C.M. Maial Armadilha luminosa' (29, DZUP).Rio de Janeiro: 'COLEÇÃO\ CAMPOS SEABRA' 'FLORESTA da TIJUCA\ D. Federal BRASILI 22././1958\ C.A. Campos Seabra' (1옹 DZUP); 'COLEÇÃO। CAMPOS SEABRA' 'FLORESTA da TIJUCA\ D. Federal BRASILI 9.II.1958। C.A. Campos Seabra' (2甲, DZUP); 'COLEÇÃO। CAMPOS SEABRA' 'FLORESTA da TIJUCA\D. Federal BRASIL\ 15.III.1958 C.A. Campos Seabra'

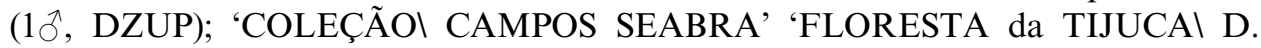
Federal BRASILI 17 Março $1958 \backslash$ C.A. Campos Seabra' (1ㅇ, DZUP); 'COLEÇÃO\ CAMPOS SEABRA' 'FLORESTA da TIJUCAI D. Federal BRASILI 28 Dezembro $1958 \backslash$ Luzl C.A. Campos Seabra' (1ㅇ, DZUP); 'COLEÇÃO\ CAMPOS SEABRA' 'FLORESTA da TIJUCAI D. Federal 
BRASIL\} 5 \text { Março 1960\ Luz\ C.A. Campos Seabra' (19, DZUP). São Paulo: 'Brasil, } São Paulo, Alvinlândial Estação Ecológica de Caetetus, $2^{\circ} 23^{\prime}$ S 4949’W,। 7-8. xii.1999, F.C. Passos' (19, DZUP); 'Brasil, São Paulo,\Bauru, APA Água Limpa,। $22^{\circ} 21^{\prime} \mathrm{S} 4^{\circ} 00^{\prime} \mathrm{W} \backslash$ 09.x.2008, Ninho 2\ L.M. Santos \& S. Tierney' (1옹 DZUP); 'Brasil, São Paulo,\Bauru, APA Água Limpa, $\backslash 22^{\circ} 21^{\prime}$ 'S 4900'W $\backslash$ 09.x.2008, Ninho 3\ L.M. Santos \& S. Tierney' (19, DZUP); 'Brasil - São Paulo\ Cananéia\24/VIII/ 2007 `A.P.G. Araújo (leg.)’ (1ㅇ, DZUP).

\section{Megalopta cuprea}

BOLIVIA: 'Bolivial Mapiril 1900' 'M. cupreal 1909 Friese det.' (19,DZUP)., 'cuprea\ MAPIRI (1+, DZUP). 'Nigrillani - 2500m.। Enero - 1950\ G. Williner leg.I N. Yungas - Bolívia' (2, DZUP).'Espejo - Santal Cruz Bolivial II-1962 Proser' (1今̄, DZUP). '17.648' 'Megalopta cupreal $q 904$ Friese, det.' '100.446' ‘17.648 - Bolivia,\ Mapiri, 1900.\ Col. Desconhecido’ (1온 MZUSP).

\section{Megalopta sodalis}

BOLIVIA: Cochabamba: 'Dpto. Cochabambal Prov. Chaparel Loc. villa tunari SC10-12-96 [Leg.। John Medina]' (1ㅇ, DZUP). La Paz: '17.645' 'Megalopta idalia ㅇ 904 Friese det.' ‘17.645 - Bolivial Mapiri, 1900\ Col. Desconhecido’ (19, MZUSP). BRAZIL: Acre: 'Brasil, Acrel Acrelândial 1004'S/67²5'W' '02-04/XI/ 2001 । Oliveira, Morato\\& Cunha leg.। Paracresol' (1 $q$, INPA); 'Brasil Acrel Porto AcreHumaitál 15-VI a 02-VII-92' 'Cols: Gorayeb, Penal Henriques, Edmar' 'COLETAl NOTURNA' (1+, MPEG); 'Brasil, Acrel Acrelândial $10^{\circ} 04^{\prime} \mathrm{S} / 67^{\circ} 25^{\prime} \mathrm{W}$ ' ‘02-04/XI/ $2001 \backslash$ Oliveira, Morato $\&$ Cunha leg. $\backslash$ Sal. de metila' (1 9 , INPA); 'BR AC Cruzeiro

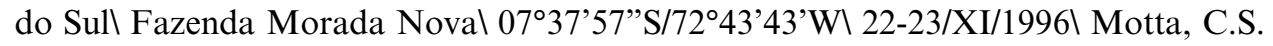
et alii col.' 'Luz mista mercúrio\ Luz negra BL e BLB \Lençol' '0019553' (10̄, INPA); 'Brasil Acrel Porto Acre, Humaital 15-VI a 02-VII-92' 'Cols: Gorayeb, Pena, Henriques, Edmar' 'Mata Terra Firme' (1 + , MPEG); 'Cultura: Mognol Armadilha

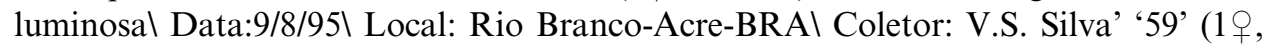
MZUSP); 'Rio Branco-AC $\backslash$ Data-03/04/00\ Col. NAVES, E.A.' (1 9 , INPA); 'Rio Branco-AC\ Data:04/04/00\Col. NAVES, E.A.' (1요 INPA); 'Brasil, AC - Rio Brancol 25-X- a 8-XI-91\F. Ramos/A. Henriques\I. Gorayeb/N Bittencourt' (2q, MPEG); 'RIO BRANCO-AC BRASIL 11/1/1996\ BARDALES, N.G. leg' (19, INPA); 'BRASIL. ACRE. RIO\BRANCO. BOSQUE\ DATA. 09/VI/1995 M.L. OLIVEIRA' (19, INPA). Amapá: 'Brasil Amapá Amapari\ TUCANO-2\9.XI.1993'

'Brasil AP\ N. Bittencourt' 'Armadilha de Luz' (1ㅇ, MPEG). Amazonas: 'BRASIL, Amazonas,\ Caruari, 505’31”S $\backslash$ 67¹0'03'. Vi.2005 Luz mista/mercúrio' 'A. Henriques \&l Vavier-Filho leg.' (3ㅇ, 1§, INPA); 'BRASIL, Amazonas\ Rio Jaú, Meriti \Mu. Novo Airão' '04-10.iv.1994\ J.A. Rafael' 'Megalopta spp.\ det. G. Melo 1996' (1ㅇ, INPA); 'BRA, Amazonas, Novol Aripuanã, lago Xadál 05¹5’39”S 60 42'32'W \ iv.2005' 'Em luz mista e BLB $\backslash$ F. Xavier, F. Godoil \& A. Lourido Leg.' (11 , INPA); 'BRASIL, AM, Tabatinga 041215S-695432W\ 03-08.ix.2005, arm.luzl J.A. Rafael \& F.F. Xavier F' $^{\circ}\left(1+10^{\lambda}\right.$, INPA). 'BRASIL, AM, Beruri, $\backslash$ Rio Purus

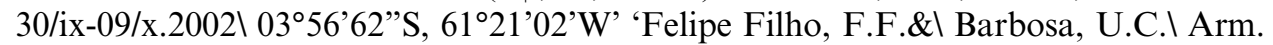
de Luz Mista' (3ㅇ, INPA); 'BRASIL, Amazonas, Riol Nhamundá, Ig. Areias\ 01³5'11’S - 57³7’32’W' '25m, 17-20.v.2008, J.A.I Rafael e equipe, arm. Luzl no 
barco' (3ㅇ, INPA); 'BRASIL, Amazonas $\backslash$ Barcelos, viii.2008\ Rio Aracá \Cuqui $0^{\circ}$

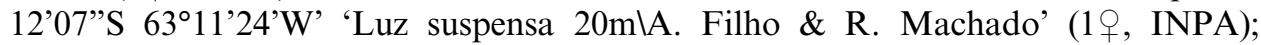
'BRASIL, AM, Barcelos\Igarapé Erere/ Corujal 0006'16”N - 6351'0”'W' ‘18-25. vi.2008. F.F. Xavier F’ $^{\circ}$. Arm. Luz' (2q, INPA); 'BRASIL, Amazonas, ‘Campo da Catuquira', \ ca $240 \mathrm{~km} \mathrm{~S}$ Manaus $\backslash$ Mata-0455.184'S $\backslash 61^{\circ} 06.619 \mathrm{~W}$ ' '21/VII/2007, em isca Expedição GEOMA\H.F. Guariento leg.' (19, INPA);'BRASIL, Amazonas,।

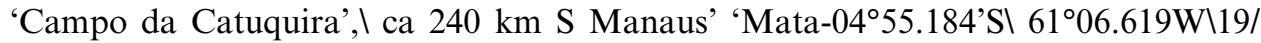
VII/2007, em iscal Expedição GEOMA $\backslash$ H.F. Guariento leg.' (19, INPA); 'BRASIL,

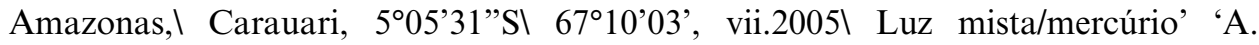
Henriques \&l Xavier-Filho leg.' (2へ̂, INPA); 'BRASIL, AM, Fonte Boal 023227S660408W $\backslash 27 . i x .2005$, arm.luz F.F. Xavier $\mathrm{F}^{\circ}$ ' (19, INPA); 'Brasil, Amaonas $\backslash$ Fonte Boal Estr. do\ Mamopina, Km,3' ‘02³2'27”S $\backslash 66^{\circ} 04^{\prime} 08^{\prime} \mathrm{W} \backslash$ 05-30 IX 2005\J.A.

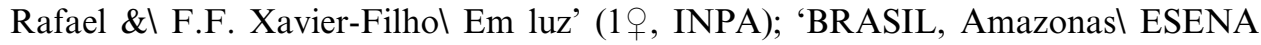

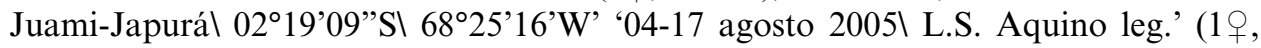
INPA); 'BRASIL, Amazonas $\backslash$ ESENA Juami-Japurá $02^{\circ} 45^{\prime} 19.76$ ' $\backslash \backslash$ 67³6'50.29’W' '04-17 agosto 2005\ L.S. Aquino leg.' (1요 INPA); 'BRASIL. Amazonas ESENA Juami-Japurál Médio Rio Juami\0157’20.4”S\6755’47.8’W’ ‘23-29 2004\ M.L. Oliveira \& F.F.I Xavier Filho leg.I armadilha luz mista' (19, INPA); 'Brasil.

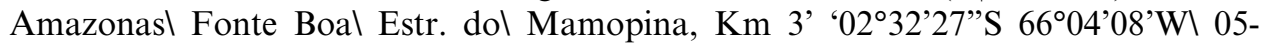

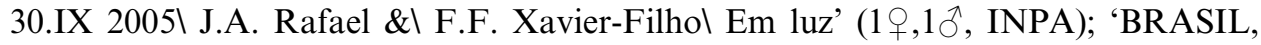
AM, Fonte Boal 023227S - 660408W $\backslash 27 . i x .2005$, arm.luzl F.F. Xavier $F^{o}$, 1 , INPA); 'BRASIL, AM, Itacoatiaral Madereira MIL, 024510S $\ 583911 \mathrm{~W}, 29-30$. xi.2005' 'arm. luminosa móvel, J.A.I Rafael, R.J.P. Machado \&l A. Silva F' ${ }^{\circ}$ ' 1 , INPA); 'Igarapé Belém\ Rio Solimões, AM\ 7-30.IV.1966। Malkin col.' (3ㅇ, MZUSP); 'Brasil: Amazonas\Igarapé Ira\ 0¹0’S, 68¹5'O\31.v.1977' ‘col. Jorge Arias' (1ㅇ, INPA); 'BRASIL-AM-ITACOATIARAI EST. AM010 KM 232 FAZENDA ARUANÃI 2.IX-1977\ L.P.A. E. RUFINO' (19, INPA); 'Brasil, Amazonas\Itapiranga, $300 \mathrm{Km}$ del Manaus, Armadilhal luminosa, 03-06.x.2010 D. Grisales \& M. Guedes' (2犬̂, DZUP); 'BRASIL: Amazonas\Igarapé Ira\ $0^{\circ} 10^{\prime} \mathrm{S}$, 68¹5'O\31-v-1977' 'col. Jorge Arias' (1\%, INPA); 'BRASIL, Amazonas\Lábrea,

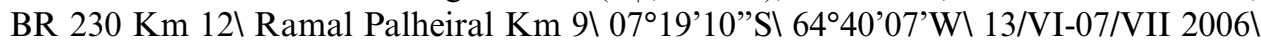
F.F. Xavier-Filho leg.' (19, INPA); 'BRA, Amazonas, Manaus,। Reserva Ducke AM010,Km26 02 $55^{\prime} 51^{\prime} \mathrm{S} 59^{\circ} 58^{\prime} 59^{\prime} \mathrm{W} \backslash 14$. iii.2003 R.entomológical Floresta’ (1ㅇ, INPA); 'Bra, Amazonas, Manaus, Res. Ducke, AM 10, Km26\0255’51”S 59 58'29'W 11.iii.2003' 'Lençol ilumnadol Clareiral S.B. Faveri leg' 'ORD: HYMENOPTERA\ FAM:HALICTIDAE' (1+, INPA); 'Brasil-Am. Manaus $\backslash$ Res. Ducke-Br. $\backslash 010$ - km.26\ Data: 08/V/77 \ cl. E. Rufino' (19, INPA); 'BRASIL AM MANAUS $\backslash$ Torre da ZF- 2/45m $\backslash 2^{\circ} 35^{\prime} 20^{\prime}$ 'S $/ 60^{\circ} 06^{\prime} 55^{\prime} \mathrm{W} \backslash 06-07 / \mathrm{I} / 1997 \backslash$ Motta, C.S. \& Vidal, J. col.' 'Luz mista mercúriol Lençol' '0019545'(19, INPA); 'BRASILMANAUS Aml Est-P/TARUMÃ Kml 13 19/12/1985 M.V.B. Garcia’ (1의, MEUFV); 'BRASIL, AM, Manaus, $\backslash \mathrm{ZF}-2$, km 34, Campinal $02^{\circ} 35^{\prime} 37^{\prime \prime} \mathrm{N} \backslash 60^{\circ}$ 12’39'W' '11.vii.2008, Arm. Luminosal J.A. Rafael \& F.F. Xavier- Filho col.' (1웅, DZUP); 'BRASIL-AM-MANAUS $\backslash$ RESERVA DUCKEI 24-X-1976 col.' (19, INPA); 'BRASIL, Amazonas Manaus\ Reserva Sokagakkai\ Lençol Luz mista\} 2 2 . iv.2004\G. Lourido leg. 'Hymenoptera\ Halicitdae\ Det. G.M. Lourido, 2004' '62' (1q, INPA); 'BRA, Amazonas, Manaus, \Reserva dos Japoneses \Sokagakkai\} 2 2 . vi.2004' 'Ordem: Hymenoptera\ Família: Halictidael Landeiro V.L. leg' '41' (1 , INPA); 'BRA, Amazonas, Novol Aripuanã lago Xadál 05¹5’39”'S 6042’32’W 
iv.2005' 'Em luz mista e BLB $\backslash$ F. Xavier, F. Godoi \& A. Lourido Leg.' (1 9 , INPA); 'BRASIL, Amazonas, Manaus, \Reserva Biológica de Campina $\backslash 11 . v i i i .2008,77 \mathrm{~m}, 2^{\circ}$ $35^{\prime} 27^{\prime}$ 'S $\backslash 60^{\circ} 1^{\prime} 51^{\prime} \mathrm{W}$ luz P.C. Grossi' (1우수, DZUP); 'BRASIL - AMAZONAS MANAUS - FUA\23/II/82\ MORAIS, J.W.' (19, INPA); 'BRASIL, Amazonas\ Manaus, Res. Duckel 07-21.xi.1994\ J.A. Rafael \& J. Vidal' 'Arm. suspensa\ Torre, 30m' (19, INPA); 'BRASIL-AMAZONAS \MANAUS- RES. DUCKE II/1995\M. J.G. HOLYIN' (2q, INPA); 'BRASIL Amazonas\ Manaus:FUA\25-V-1982\F.

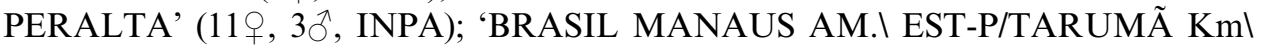
13 19/12/1985 M.V.B. GARCIA', (1+) (MEUFV); 'BRASIL: AMAZONAS MANAUS: R. DUCKEI 18-I-1982 J.A. RAFAEL' 'COPA DE ARV' (1\%, INPA); 'BRASIL, AM, Manaus ZF-2, km-34, Campinal 02³5’37'N 60¹2’39'W' '11.vii.2008, Arm. luminosa, \ J.A. Rafael \& F.F. Xavier $\backslash$ Filho col.' (1q, INPA); 'Brasil, AM, Manaus, Km 50, Ramal da vovó,\ 18-20.viii.2006,। Arm. lençol luz mista,' 'Xavier Fo, F.F.; Lourido,G.M.. Mendes, D.M.M.; Leite, K.C.A.' (1 INPA); 'BRASIL-AMAZONAS $\backslash$ MANAUS $\backslash 24-I I I-82$ F.U.A.I Latorre L.R.' (19, INPA) 'BRASIL AM, Manaus, ZF- 2 km-34, Base LBA. $102^{\circ} 35^{\prime} 37^{\prime}$ S - 60¹2’39'W' '09-10.viii.2008, arm. luzl nível do solo, J.A. Rafaell \& F.F. Xavier F $^{\circ}$ (1 9 , INPA);'1007' 'MANAUS-AM $\backslash$ PDBFF 29/11/89\ M.L. OLIVEIRA' (19, MEUFV); 'Brasil. Amazonas\ Reserva Duckel Am 010 Km26' '07-18 Dez. 2005।

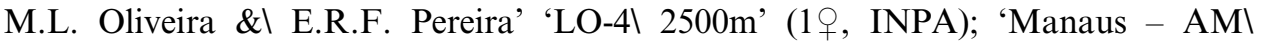
PDBFF 29/11/89 \M.L. Oliveira' '1009'(1, MEUFV); 'BRASIL: Amazonas\ BR

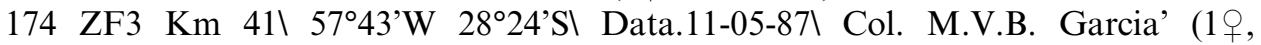
MEUFV); 'BRASIL, AM, Manaus ZF2\ km-14, Torre,023521S-\600655W, 19-22. iii.2004\luz mista/ BL, BLB, lençol' '40mt alt. J.A. Rafael, \C.S. Motta, F.F. Xavier $\mathrm{F}^{\circ}, \backslash$ A. Silva $F^{\circ}$, J.T. Câmara' (1ㅇ, INPA); 'BRASIL: AMAZONAS $\backslash$ MANAUS: P. DAS LARANJEIRAS $\backslash$ 02.VI-1981 \Eq. JORGE ARIAS $\backslash$ ARM. 02 LUZ. 15M’ (1 INPA); 'BRASIL, AM, Manaus, ZF-2\ km-14, Torre, 023521S- $600655 \mathrm{~W}, 18-21$. ii.2004\ luz mista/ BL, BLB, lençol' '40 mt alt. J.A. Rafael, C C.S. Motta, F.F. Xavier $F^{\circ} \backslash \&$ A. Silva F $F^{o}, S$. Trovisco (1 9 , INPA); ' $1088^{\prime}$ ' MANAUS-AM $\backslash$ PDBFF 07/12/89 $\backslash$ M.L. OLIVEIRA' (1 9 , MEUFV); Manaus - AM \PDBFF 23/1/90\ M.L. Oliveira'

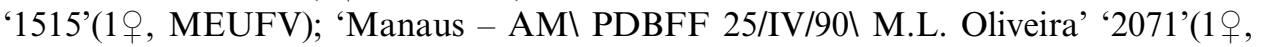
MEUFV); 'BRASIL: Amazonas RESERVA DUCKEI 14-I-1978\ O. RODRIGUES, A. SOARES' (1, DZUP); 'BRASIL, Amazonas, Manaus, ZF-2km 34, Base LBA, \09.vii.2008, 100m, 2³5’33”S \60¹2’52’W arm. luz dossel $\backslash$ P.C. Grossi col.' (19, DZUP); 'BRASIL-AMAZONAS $\backslash$ MANAUS $\backslash 25-\mathrm{V}-82$ F.U.A.I Latorre L.R.' (19, INPA); 'BRASIL: Amazonas\ Manaus R. Ducke\2/-22/I/1993। MOTTA, C.S. \& ALENCAR, C.I col.\(LM-LENÇOL)\CANTINA' (1 9 , INPA); 'BRASIL: Amazonas 26 km NE Manaus\ Reserva Ducke\03-XI-1988' 'J.A. Rafaell Arm. Suspensal 30 metros' (1\%, INPA); 'BRASIL, AM, Manaus, ZF-2\ km-14, Torre, 023521S-\600655W, 15-18.vi.2004\ lençol: luz mista e BLB' '40 mts alt. J.A.

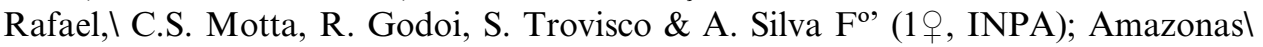

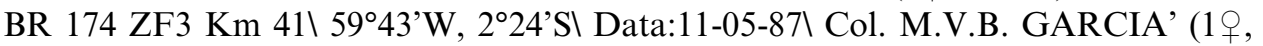
MEUFV); 'EUGENOL\ No14' 'Manaus - AM\BRASIL, 10/12/88 E.F. Morato' 'fornix'. (1q, DZUP). 'BRASIL - AMAZ.I Manaus, R. Duckel 5.v.77 - Dellome'

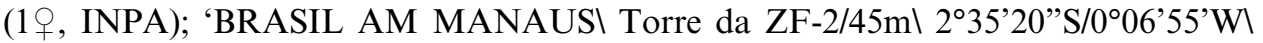
06-07/I/1997\Motta,C.S. \& Vidal, J. col' 'Luz mista mercúriol Lençol' '0019543' (1오, INPA); 'BRASIL- AM- MANAUS $\backslash$ RESERVA- DUCKE\ 24-X-1976 col?' (19, INPA); 'Brasil. Amazonas\ Reserva Ducke\Am 010 Km26' '07-18 Dez. 2005\ M.L. 
Oliveira $\& \backslash$ E.R.F. Pereira' 'LO-5 $\backslash 2500 \mathrm{~m}$ ' (19, INPA); 'Brasil Amazonas $\backslash$ AM 010Km $45 \backslash$ 26.IV.1982 E.L. Oliveira' (1ㅇ, INPA); 'Brasil. Amazonas $\backslash$ Reserva Ducke Am 010 Km26' '07-18 Dez. 2005\M.L. Oliveira \&\ E.R.F. Pereira' 'LO-8\500m' (2 9 , INPA); 'Brasil. Amazonas\ Reserva Ducke\ Am 010 Km26' '07-18 Dez. 2005। M.L. Oliveira \&\ E.R.F. Pereira' 'LO-8\1500m' (19, INPA); 'SALICILATO DEl METILA $\backslash N^{\circ} 20$ ' 'Manaus-AM $\backslash$ BRASIL, 6/10/88 $\backslash$ E.F. Morato' 'Megalopta $\backslash$ fornix ?' (1옹 DZUP); 'Brasil, AM, Manaus $\backslash$ Reserva do Cuieiras $\backslash 58^{\circ} 15^{\prime} \mathrm{S} 60^{\circ} 13^{\prime} \mathrm{W} \backslash 26$. xi.2011, A. Cézar' (2ð, DZUP); 'BRA, AM, Manaus $\backslash$ PDBFF - Colosso $102^{\circ} 23^{\prime} 58^{\prime}$ 'S - 5952’20`W 23-27.xi.2009\ D. Storck-Tonon Leg.' (1ㅇ, INPA);'BRA, AM,

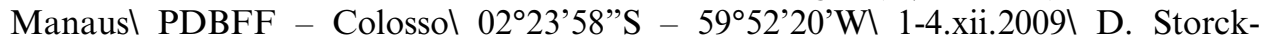
Tonon Leg.' (2ᄋ, INPA); 'BRA, AM, Manaus PDBFF - Colossol 02 23'58'S 5952'20'W \11-15. i.2010 D. Storck-Tonon Leg.' (10․ INPA); 'BRA, AM, Manaus $\backslash$ PDBFF - Colosso $02^{\circ} 23$ '58”'S - 5952’20’W $\backslash 27-29$. iii.2010 D. Storck-Tonon Leg.' (4ㅇ, INPA); 'BRA, AM, Manaus $\backslash$ PDBFF - Colosso $02^{\circ} 23^{\prime} 58^{\prime}$ 'S - 5952’20’W $\backslash 28$ 30.iv.2010 \ D. Storck-Tonon Leg.' (2 + , INPA); 'BRA, AM, Manaus\ PDBFF -

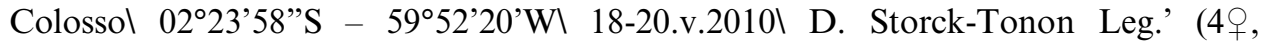
INPA); 'BRA, AM, Manaus\ PDBFF - Colosso $02^{\circ} 23^{\prime} 58^{\prime}$ 'S - 5952’20'W $\backslash 23-27$. vi.2010 D. Storck-Tonon Leg.' (7ㅇ, INPA); 'BRA, AM, Manaus $\backslash$ PDBFF -

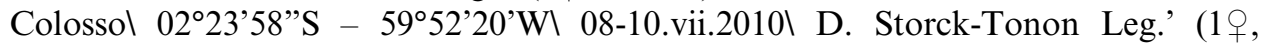
INPA); 'BRASIL, AM, Manaus, $\backslash$ Reserva Ducke, $\backslash$ AM 010 km 26\255'54”S; 59 58’29'W 10-14.iii.2009\ Lençol Brancol T. Mahlmann Leg' (10َ, INPA); 'Igarapé Belem\ Rio Solimões, AM $\backslash$ 7-30.IV.1966 Malkin col.' (3ㅇ, INPA); 'BRASIL:

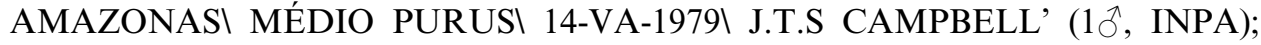
'Brasil, AM, Pres. Figueiredo, $\backslash$ Est. Balbina, Ramal do 13,\27-28.I.2006, Arm. luz móvel,' 'J.A. Rafael, F. Xavier F'o Silva A.I J.S. Duarte \& D.M. Mendes' (19, INPA); 'BRASIL, Amazonas\ Parque Nac. do Jaúl 17-19/nov/2005' 'M.L. Oliveira \& E.R.I F. Pereira leg.। campinarana' (19, INPA); 'Brasil $\backslash$ Amazonas $\backslash$ PARNA do Jaú \19-III à 05-IV-\2003' 'M.L. Oliveira \&\ J.A. Cunha leg.\ Campinarana' (19, INPA); 'Brasil $\backslash$ Amazonas $\backslash$ PANA do Jaúl 22 a 28-VI-\2003' 'M.L. Oliveira \&\J.A. Cunha leg $\backslash$ Em roçado' (1 + , INPA); 'BR, AM, Pq. Nac. do Jaúl Mg. dir. baixo rio Jaúl 1 ${ }^{\circ} 97^{\prime} S / 61^{\circ} 45^{\prime} \mathrm{W} \backslash 18-19 / X / 1993 \backslash$ Motta, C.; Andreazze, R.। \& Vidal, J. col.' 'luz mista mercúrio $\backslash$ Luz negra BL e BLB $\backslash$ Lençol' (19, INPA); 'BR, AM, Pq. Nac. do Jaúl Mg. dir. baixo rio Jaúl 197’S/61²5’W 26-27/X/1993\ Motta, C.; Andreazze, R.I \& Vidal, J. col.' 'Lençol c/luz mista mercúrio, luz negra BL e BLB' (1 9 , INPA); 'BR, AM, Pq. Nac. do Jaúl Mg. dir. baixo rio Jaúl $1^{\circ} 97^{\prime} \mathrm{S} / 61^{\circ} 45^{\prime} \mathrm{W} \backslash 27-28 / \mathrm{X} / 1993 \backslash$ Motta, C.; Andreazze, R.I \& Vidal, J. col.' (1,2,1ð, INPA); 'BRASIL, Amazonas, Pq\ Nac.Jaú. Rio Carabinani\0159S-6132W. 07-17.iv.\ 1994. C. Motta e outros'

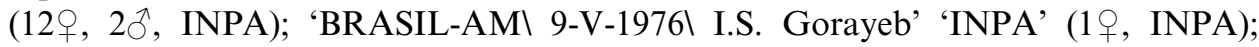
'Brasil, Amazonas, Pq.I Nac. Jaú, Ig. Miratucal 157’8S; 6149’19’W' ‘14-29. vii.1993\ Andreazze, R.; Costa, W.I \& Aquino, L. col.' 'lençol c/luz mistal mercúrio, luz negral BL e BLB' $\left(2 \propto, 1{ }^{\lambda}\right.$, INPA); 'BR, AM, Pq. Nac. do Jaúl Mg. dir., baixo rio Jaúl $1^{\circ} 97^{\prime} \mathrm{S} / 51^{\circ} 45^{\prime} \mathrm{W} \backslash 27-28 / \mathrm{X} / 1993 \backslash$ Motta, C; Andreazze, R.I \&

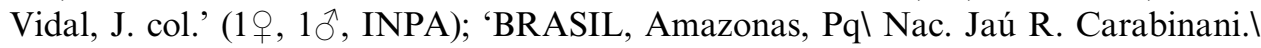
0159S-6132W. 07-17.iv.I 1994. C. Motta e outros' (4ㅇ,1ð,, INPA); 'BR, AM, Pq. Nac. do Jaúl Rio Carabinani mg. dir $\backslash 1^{\circ} 59^{\prime}$ S/61³2’W $\backslash 14-15 / I V / 1994 \backslash$ Motta, C. et al. col.' (1 $\jmath^{\lambda}$, INPA); 'BR-AM Rio Carabinanil 28-29/IV/1995 Motta et al col.' 'Luz mista mercúriol Luz negra BL e BLB \Lençol' '0019562'(1ㅇ, INPA); 'Brasill Amazonas\PARNA do Jaúl 19-III à 05-IV-I 2003' 'M.L. Oliveira \&l J.A. Cunha 
leg. \Campinarana' (1 q, INPA); 'Brasil $\backslash$ Amazonas $\backslash$ PARNA do Jaúl 18 a 21-V-2003' 'M.L. Oliveira \&। J.A. Cunha leg. $\backslash$ Campina' (1, INPA); 'BR AM Pq Nac. do Jaúl Rio Carabinani mg. dir $\backslash 1^{\circ} 59 \mathrm{~S} / 61^{\circ} 32^{\prime} \mathrm{W} \backslash 11-12 / \mathrm{IV} / 1994 \backslash \mathrm{Motta}, \mathrm{C}$. et al. col.' 'Luz mista mercúrio\Luz negra BL e BLB\Lençol' (1 + , INPA); 'BRASIL, Amazonas, Pq\ Nac. Jaú, R. Carabinani.I 0159S-6132W, 07-17.iv.I 1994, C. Motta e outros’ (1 $q$, INPA); 'BRASIL, Amazonas, Pq.I Nac. Jaú, Ig. Miratucal 157'8”S; 6149'19’W' '14-29.vii.1993। Andreazze,R; Costa,W.I \& Aquino, L. col.' 'Lençol c/luz mistal mercúrio, luz negral BL e BLB' (1+, INPA); 'BRASIL, AM, Resex Uninil Rio Unini, Lago 03 Bocas, $\backslash 01^{\circ} 34^{\prime} 56^{\prime}$ 'S, 6258'28'W 14-22.vii.2004' 'Luz mista del mercúrio+BLB (lençol)\ A. Silva F. \& L. Aquino.' (7q, INPA); 'BRASIL, Amazonas\Resex Uninil Rio Uninil Lg. Galomãnhal Terra Firmel $01^{\circ} 37^{\prime} \mathrm{S} 62^{\circ}$ 59'W' '13-28.vii.2004\ M.L. Oliveira,\L. Aquino \&\ A. Silva-Filho leg.\luz mista e BLB' (19, INPA); 'bôca do Rio Purus\ mar. Esq., AM\ 2-5.IV.1967 $\backslash$ Exp. Perm. Amaz.' (1 $\left.\delta^{\top}, \mathrm{MZUSP}\right)$; 'BRASIL AM $\backslash$ Rio Carabinani\ Terra Firmel Em vôo' '02

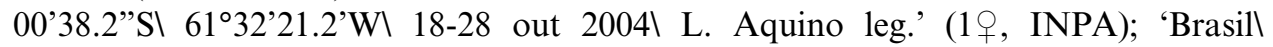
Amazonas\ PARNA do Jaúl 19-III a 05-IV-I 2003' 'M.L. Oliveira \&l J.A. Cunha leg. $\backslash$ Campinarana' (1 , INPA); 'Brasil, AM\ PARNA do Jaúl 10-24 Nov 2003' 'M. L. Oliveira \&\ J.A. Cunha leg.। Vila\ Serigalzinho' (1, INPA); 'Humaitá AM Brazl N.B.M Brantjes $\backslash 70050104 \backslash 20 . X I .1977$ ' Megalopta $\backslash$ Det. 1979\ N.B.M Brantjes' (1 9 , RMNH); 'Humaitá AM Brazl N.B.M Brantjes\ 70050103\20.XI.1977' 'Megalopta\ Det. 1979\ N.B.M Brantjes' (1q, RMNH); 'Humaitá AM Brazl N.B.M Brantjes\ 70050104\20.XI.1977' 'Megalopta \et. 1979\ N.B.M Brantjes' (19, RMNH); 'Humaitá AM Braz\ N.B.M Brantjes\70050105\20.XI.1977' 'Megalopta\ Det. $1979 \backslash$ N.B.M Brantjes' (1q, RMNH); 'Humaitá AM Brazl N.B.M Brantjes\ 70050106\20.XI.1977' 'Megalopta Det. 1979\ N.B.M Brantjes' (19, RMNH); 'Humaitá AM Braz\ N.B.M Brantjes\70050107\20.XI.1977' 'Megalopta\ Det. $1979 \backslash$ N.B.M Brantjes' (1ㅇ, RMNH); 'Humaitá AM Brazl N.B.M Brantjes\ 70050106\20.XI.1977' 'Megalopta \et. 1979\ N.B.M Brantjes' (19, RMNH); 'Humaitá AM Braz\ N.B.M Brantjes\70050108\20.XI.1977' 'Megalopta\ Det. 1979\ N.B.M Brantjes' (19, RMNH). Bahia: '17.647' '17.647 - Brasil, Belmonte, Bahia.। Col. Desconhecido' '100.447' (1+, MZUSP); 'Brasil, Bahia, Camacã, \ Serra Bonita, 800m, $\backslash 15^{\circ} 23^{\prime} \mathrm{S} 39^{\circ} 34^{\prime} \mathrm{W}, \backslash 12.1 .2007$, G. Melo, $\backslash$ atraídas por luz, $\backslash$ 20:00-23:00'

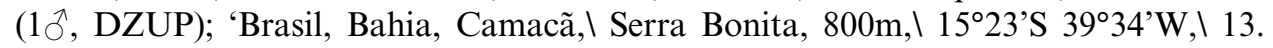
i.2007, G. Melo, \atraídas por luz, 4 4-5:00' (2 + , DZUP); 'Brasil, Bahia, Camacã,। Serra Bonita, 800m, $\backslash 15^{\circ} 23^{\prime} \mathrm{S} 39^{\circ} 34^{\prime} \mathrm{W}, \backslash 14.1 .2007$, G. Melo, \atraídas por luz, $\backslash 4-5: 00^{\prime}$

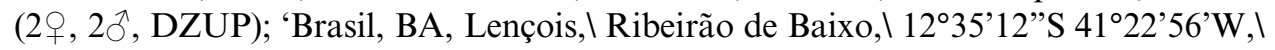
340m, 04.vi.2007, J.A.I Rafael \& F.F. Xavier Fo.,। luz' (19, DZUP); 'Brasil, BA,

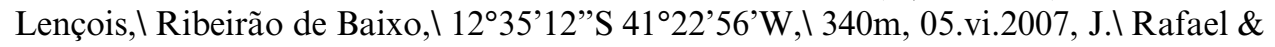

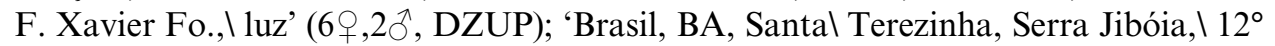

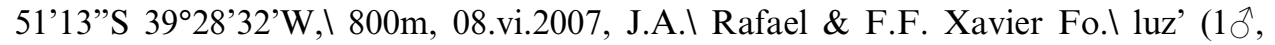
DZUP); 'MZUEFS\ Brasil, Bahia\ Mucugê, Projeto\ Sempre Viva\30/VI/2008\ Lg. Franco,Emanuella L.' 'PLANTA: C. wurdackiil HORA: 5:55' 'MESTRADO। FRANCO, E.L.I 072' 'MZUEFS $\backslash$ \#39585' (19, DZUP). Espírito Santo: 'Brasil, Espírito Santo,। Guarapari, Praia del Setiba, 1-8.i.1996,। 40²6’W 20³8’S Restinga, G A R Melol Armadilha Malaise' (1+, DZUP); 'Brasil, ES, Linhares\ 19.XI.1990' (1ㅇ, CPDP); '22-24-I-2003 COLÔNIAI TIROL, SANTA LEOPOLDINAI ES, 600m, MIELKE \&l CASAGRANDE LEG.' (2へ̂,, DZUP); 'Santa Leopoldina-ES\Colônia Tirol-Brasil $22-24 /$ I/2003\Mielke e Casagrande leg' 
(1ठ̋, DZUP); 'Rib. do Engano E.S.I Vale do Itaúnal Trav e Santos-9-10-42' (19, DZUP). Goiás: BRASIL, GO, Alto Paraísol Chapada dos Veadeiros\ Rio São

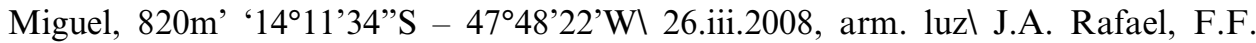
Xavier $F^{\circ}$ ' (1今, INPA); '13078-38789' 'Caldas Novas GO\BRASIL 17/10/2006 S.C. Augusto' (19, DZMG); 'BRASIL, GO, Caldas $\backslash$ Novas, PE Serra de $\backslash$ Caldas Novas, 700-1000m' '1746'13”S - 48³9'22'W $22-23 . i i i .2008$ arm. luzl J.A. Rafael, F.F.

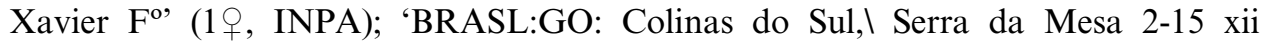
1995, $11^{\circ} 01^{\prime} \mathrm{S}, 48^{\circ} 12^{\prime} \mathrm{W}$ Silvestre, Dietz \& Campaner-cerrado' (1웅 MZUSP); 'Faz. Cachoerinhal Jataí, Goiás-Brasill X:1962' 'Ninho No2\ Karol Lenko' (19, DZUP). 'Faz. Cachoerinhal Jataí, Goiás-Brasill X:1962' 'Ninho No2' (1을 DZUP). Mato Grosso: 'MT Aripuanã \Resv. Humbolt\ março 1977' 'Brasil Mato Grossol WL Overal Col' 'Megalopta $\backslash$ cf. amoena $\backslash$ (Spinola)\ det. Camargo-82.' (29, MPEG); 'Brasil, MT\6 km a W $\backslash$ de Chapada dos Guimarães, $770 \mathrm{~m} \backslash 15.452^{\circ} \mathrm{S} 55.806^{\circ} \mathrm{W}, \backslash 8$. ix.2012, Cavichioli, Melo, Rosa \& Santos' 'Armadilhal Luminosa' (3․, 10 DZUP); 'BRASIL, MT, Noval Lacerda, Cascata Uirapuru\142452S - 5927223W 28.iv.2006 J.A. Rafael \&\ F.F. Xavier F, arm. luz' (19, INPA); 'Brasil, Mato Grosso, $\backslash 18$ km W de Noval Mutum, Faz. Buriti, $\backslash$ 12.i.2000, HF Mendes' (1 9 , DZUP). 'BRASIL MT Noval Mutum 05.I.2000\ H.F. Mendes leg.' (19, LEBIC). 'PARECIS \M. Grosso Brasil \XI-1960\M. Alvarenga leg' (2q, DZUP); 'BR-29 RIO JURUENA। M. Grosso BRASILI XI-1960\ M. Alvarenga leg' (2ㅇ, DZUP); 'Chapada dos\ Guimarães (Buriti)\MT BRASIL X.1972\ G.R. Kloss \& F. Val' (1ㅇ, DZUP); 'Brasil, Mato Grosso, 18km W de Noval Mutum, Faz. Buriti, 12.i.2000, HF Mendes' (1+, DZUP); 'Brasil MT\Chap. dos Guimarães $\backslash$ Colégio Ágr. Buriti 13 a 17-III-1986\Col I.S. Gorayeb' 'Armadilha\1,6m\Suspensa (1ð̃, MPEG); BRASIL, MT, Noval Lacerda, Cascata Urapuru\142452S - 592723W 28.iv.2008 J.A. Rafael $\& \backslash$ F.F. Xavier F ${ }^{\circ}$, arm. luz' (1 9 , INPA):'Nova Xavantina MT BR \CUNX - bacaba luz 29/II/97\ Boreira RL' (19, RPSP); 'Utiariti Rio Papagaio, Mt $\backslash$ 27.X.1966 Lenko

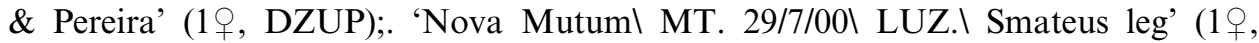
RPSP);'BC1-R14, Ribeirão Cascalheiral - MT, Br, 1249’S, 5146’W 21/VIII/1997,

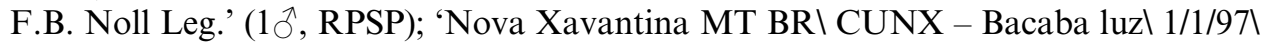

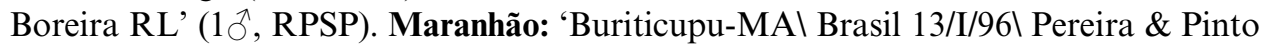
leg.\635' 'Horário: 7-8\ N Pl: 7!' ‘47’ (1ㅇ, INPA). 'Igarapé Gurupi-Umal Aldeia Araçu, Ma.I $50 \mathrm{Km}$ E. de Canindél V.1968 Malkin ol.' (3ㅇ, 1ðへ, MZUSP). Minas Gerais: 'Brasil, Minas Gerais, 13 km, $\backslash$ NE de Ipanema, Fazendal Montes Claros, 400m,\ 29-i-30.i.2003 Mielke \&l Casagrande, armadilhal luminosa' (19우 50̂, DZUP); 'BRASIL: MG\ Nova Lima 850m\1-10-i.1985\V.O. Becker col' (19, DZUP); '5-8-XII-2002\ PETI, SÃO GONÇALO DO RIO\ABAIXO, MG, $560 \mathrm{ml}$ MIELKE, LEG.' (1 9 , DZUP); '29-i-3-ii-2003 ESTAÇÃO। BIOLÓGICA DE CARATINGA, \CARATINGA, MG, 400m\MIELKE \& CASAGRANDE LEG.' (19, DZUP). Pará: 'Brasil Parál Alenquer 2 julho 1979' 'Brasil Parál W França' (19, MPEG); 'BRASIL, PA, Belterral FLONA Tapajós, 100m\02³6'15”'S - 54 ${ }^{\circ}$ 56’35'W' '15-16.iv.2008, arm. luzl J.A. Rafael, F.F. Xavier F'.' (1q, INPA); 'BRASIL:PA\ Belém, 20m\10-15.xi.1984\V.O. Becker col' (1ㅇ, DZUP); 'Brasil Pará \Benevides\ Est. Neopolis\Sítio D. Doca\VII.1991' 'Brasil Pará \. Overal' (19, MPEG); 'Brasil Parál Benevides\MORELÂNDIA\27-29.VI-1988' 'Brasil Parál F.F. Ramos' 'Armadilha\1,6m\ Suspensa' (19, MPEG); 'Brasil Pará BENEVIDES 15-III-1990' 'Brasil Parál W. Overal' (1 q, MPEG); 'Pará Bujarul 24-III-1978' 'Brasil Parál N. de Souza' (19, MPEG); 'Pará Bujarul 24-III-1978' 'Brasil Parál P. Nolasco' 
(1 9, MPEG); 'Pará Bujaru\25-III-1978’ 'Brasil Parál P. Nolasco' (3q, MPEG); 'Pará Bujarul 15-IX-1978' 'Brasil Parál R B Neto' (1, MPEG); 'Brasil-PA-Melgaçol Caxiuanã ECFPn\26-VIII-1995\ R.M. Valente' 'Em inflorescêncial masculina del Attalea maripa' 'Hymenoptera: Apocrital Aculeata: Apoidea:\ Apidae:\Incorp: 17/

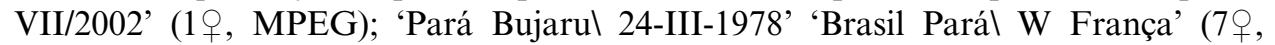
DZUP); 'Pará Cachimbol 16-22-VI-1995' (10̄, MZUSP); 'Canindél Rio Gurupi, Pará IV.1963 Malkin\\& Pinheiros col.' (1へ̄, MZUSP); 'Coraci - 15 km. NW Canindé, Rio Gurupi\ Pará- IV.1963\ B. Malkin col.' (1우, MZUSP); 'Brasil Parál Bujaru\ 15-IX-1978' 'Brasil Parál R.B. Neto' (5, MPEG); 'BRASIL: PA\Capitão Poçol 19-22.xi.1984\ V.O. Becker col.' (2ᄋ,1 ${ }^{\lambda}$, DZUP); 'Brasil Parál Serra Nortel SERRARIAI COL.NOTURNAI 19-X-1984' 'MPEG HYM 11005582 ' (19, MPEG); 'Brasil Pará Serra Nortel MANGÂNES\COL. NOTURNA\24-X-1984' 'Brasil Parál R.B. Neto' 'MPEG HYM $\backslash 11005590$ ' (19, MPEG); 'Brasil Parál Serra Norte\ CALDEIRÃO\COL. NOTURNA\ 24-X-1985' 'Brasil Parál F.F. Ramos' 'MPEG HYM\11005607' (19, MPEG); 'Brasil Pará \erra Nortel CALDEIRÃO\} COL. NOTURNA\25-X-1985' 'Brasil Parál F.F. Ramos' 'MPEG HYM\11005606' (1 9 , MPEG); 'Brasil Parál Serra Nortel CALDEIRÃO\COL. NOTURNA\25-X1985' 'Brasil Parál F.F. Ramos' 'MPEG HYM $\backslash 11005606$ ' (19, MPEG); 'Brasil Pará Serra Nortel CALDEIRÃO\COL. NOTURNA\ 25-X-1985' 'Brasil Parál W. França' 'MPEG HYM 11005604 ' (19, MPEG); 'Brasil Parál Serra Nortel CALDEIRÃO\COL. NOTURNA\ 25-X-1985' 'Brasil Parál R. B. Neto' 'MPEG HYM\ 11005603' (19, MPEG); 'Brasil Parál Serra Norte\CALDEIRÃO\COL. NOTURNA\25-X-1985' 'Brasil Parál F. F. Ramos' 'MPEG HYM 11005605 ' (1へ̂,, MPEG); 'Brasil Parál Serra Nortel PARAUABEBAS\COL: NOTURNA\ 7XI-1985' 'Brasil Parál W. França' 'MPEG HYM $\backslash 11005609$ ' (19, MPEG); 'Brasil Pará Serra Nortel CALDEIRÃO\ C/LUZ\ 27-X-1984' (1 q, MPEG); 'Brasil Parál Serra Nortel PARAUAPEBAS\COL.NOTURNA\ 7-XI-1985' 'Brasil Parál W. França' 'MPEG HYM\11005608' (19, MPEG); 'Brasil Parál Serra Nortel MANGANES\ COL. NOTURNAI 06.IX.1985' 'Brasil Parál Márcio Zanuto' 'MPEG HYM \11005599' (1 9 , MPEG); 'São M do Guamal 24-3-1964' 'Brasil PAl W. França Col.' 'Megalopta $c f$. amoena (Spinola)\ det. Camargo-82.' (1 9 , MPEG); 'Brasil Pará Tucuruíl Rio Tocantins IL. TOCANTIS $\backslash$ 06-VII-1984' 'Brasil Pará Col. B. Mascarenhas' (1ㅇ, MPEG); 'Brasil Pará Ourém\ Patauateua/ Faz. Gavião Reall 30.IV a 3.v.1992/Arm. Luzl Col. B. Mascarenhas e eq' (1 9, MPEG); 'Brasil Parál Ourém\ Patauateua 21 .Viii.1992' 'Brasil Parál B. Mascarenhas' 'Armadilhal de Luz'

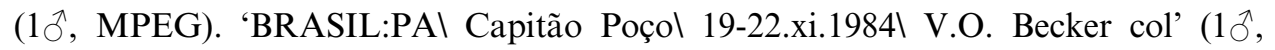
DZUP); 'Brasil Pará Ourém\ Patauateua/Faz. Gavião Reall 30.IV A 3.V.1992/ Arm. Luzl Col. B. Mascarenhas e eq.' (1ठ̄̄, MPEG); 'Peixe Boil E.F. del Bragança' 'Brazill Estado dol Pará' (1+, DZUP); 'Brasil Parál Serra Nortel Fofocal Col. NOTURNAI 18-IX-1985' 'Brasil Parál J. Dias' 'MPEG HYM\11005597' (1+, MPEG); 'Brasil Parál Serra Nortel SERRARIAI COL. NOTURNAI 19-X-1984' 'MPEG HYM\11005584' (19, MPEG); 'Brasil Pará Serra Nortel CALDEIRÃO\ 14.IX.1983' 'Brasil Parál F.F. Ramos' 'MPEG HYM 11005594 ' (1오․ MPEG); 'Brasil Parál Serra Nortel CALDEIRÃO\C/LUZI 27-X-1984' 'MPEG HYM। 11005593' 'Halictidael Megalopta\ M.C. Almeidal det. 1985' (19, MPEG); 'Brasil Pará Serra Nortel CALDEIRÃO\C/LUZ\27-X-1984' 'MPEG HYM \11005586' (19, MPEG); 'Brasil Parál Serra Nortel SERRARIA\COL. NOTURNAI 19-X1984' 'MPEG HYM 11005578 ' (1+9, MPEG); 'Brasil Parál Serra Nortel 
SERRARIAI COL. NOTURNAI 19-X-1984' 'MPEG HYM $\backslash 11005581$ ' (19, MPEG); 'Brasil Parál Serra Nortel SERRARIA\COL. NOTURNA\19-X-1984' 'MPEG HYM 11005579 ' (1ㅇ, MPEG); 'Brasil Parál Tome-Açul 18-IX-1978' 'Mata de terra firmel Isca iluminosal Captura noturna' (2甲, MPEG); 'Brasil Parál Tome-Açul 18-IX-1978' 'Brasil Parál R B Neto' (1q, MPEG); 'BRASIL, Pará, Tucuruíl Ig. Água Fria, 035052S-494704W, 02.xii.2001' 'J.A. Rafael \& J. Vidall Arm. Malaise' (1ㅇ, INPA); 'Brasil Pará Tucuruíl Rio Tocantis\SAÚDE\ 5a7-VI1984' 'Armadilha Malaise' (19, MPEG); 'Brasil Pará Tucuruíl Rio Tocantis\IL. TOCANTIS $\backslash$ 06-VIII-1984' 'Brasil Pará Col. B. Mascarenhas' (2ㅇ, MPEG); 'Brasil Pará Tucuruíl Rio Tocantis\BAGAGEM\27-VI-1984' 'Brasil Parál W.L. Overal' (19, MPEG); 'BRASIL:PA:\ UTINGA,\30.IX.1965\P. Waldir col.' (1ðð, MZUSP); 'BRASIL: Parál Urua, 65 km SW Itaituba on BR230\X-12-15-1977\ B.C. Ratcliffe' (1q, INPA). Paraíba: 'Brasil, PB, Mamanguapel Res. Guariba, Cabeçal do Boi 2122/11/1992\ Armadilha Luminosal Creão \& Martins cols' (19, UFPB). Paraná:

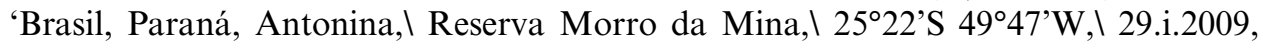
Armadilhal Shannon\ M.L.P. Guedes' (3q, DZUP); 'Brasil, Paraná, Antonina,।

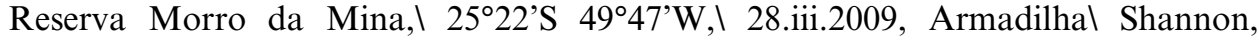
02:30h\M.L.P. Guedes' (19, DZUP); 'Brasil, Paraná, Antonina,\ Reserva Morro da Mina, $\backslash 25^{\circ} 22^{\prime} S 49^{\circ} 47^{\prime} \mathrm{W}, \backslash 1$ 12.v.2009, Ninho $1 \backslash$ L.M. Santos' (1ㅇ, DZUP); 'Brasil, Paraná, Antonina, \Reserva Morro da Mina, $\backslash 25^{\circ} 22^{\prime}$ S 4947’W, $\backslash 12 . v .2009$, Ninho $1 \backslash$ L.M. Santos' (1亏̄, DZUP); 'Brasil, Paraná, Antonina, \Reserva Morro da Mina, $\backslash 25^{\circ}$

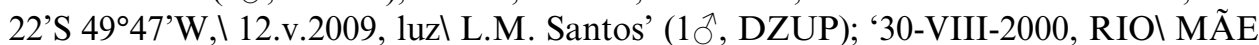
CATIRRA, 200m\MORRETES,PR\O. MIELKE LEG.' (2ô, DZUP); '31-I-1998। Castelhanos, S.I José dos Pinhais, \PR. 700m. C. Mielke' (2甲, DZUP); 'PARQUE EST. MARUMBI $\backslash$ EST. GRACIOSA-PR\REC. BELA VISTA\19/I/94\PINTO JR, A.R. COL' (1 ${ }^{\jmath}$, DZUP), 'Brasil, Paraná, Guaratubal Estrada dos Castelhanos, I 25.XI.2009, L.M. Santos.' (19,2 ô, DZUP). Pernambuco: 'CARUARU, PE\ Brejo dos Cavalos\ Brasil, 25.9.1999\ C. Schlindwein leg.' '769 UFPE\ Luz Negra, L114'

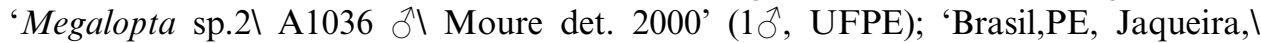
RPPN Frei Caneca, $\backslash$ 0843’15’S 3550’27’W,I600m, 28.v.2007, J.A.I Rafael \& F.F.

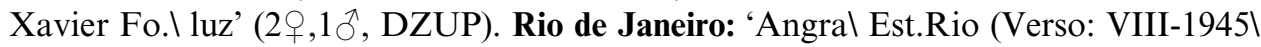

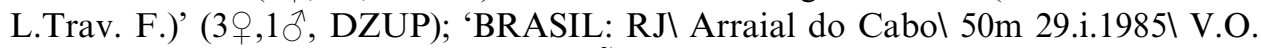
Becker col' $(2 \propto, 2 \hat{\jmath}$, DZUP); 'COLEÇÃO $\backslash$ CAMPOS SEABRA' 'FLORESTA da TIJUCA \D. Federal BRASIL\Esquilos 6 janeiro 1957 C.A. Campos Seabra\ LUZ' (1+, DZUP); 'COLEÇÃO $\backslash$ CAMPOS SEABRA' 'FLORESTA da TIJUCA\D. Federal BRASILI Esquilos-Luzl 3 Fevereiro 1957 C.A. Campos Seabra'(3ㅇ, DZUP); 'COLEÇÃO CAMPOS SEABRA' 'FLORESTA da TIJUCA\ D. Federal BRASIL\ 27.VIII.1957\ C.A. Campos Seabra'(19, DZUP); 'FLORESTA da

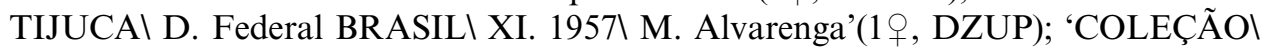
CAMPOS SEABRA' 'FLORESTA da TIJUCA \D. Federal BRASIL\ 16.I.1958\C. A. Campos Seabra'(1ㅇ, DZUP); 'COLEÇÃO\CAMPOS SEABRA' 'FLORESTA da TIJUCA\ D. Federal BRASIL\} 2 8 \text { Dezembro } 1 9 5 8 \backslash \text { C.A.C. Seabra\ LUZ'(1의, } DZUP); 'COLEÇÃO $\backslash$ CAMPOS SEABRA' 'FLORESTA da TIJUCA\ D. Federal BRASIL\14.I. 1959\C.A. Campos Seabra'26' (19, DZUP); 'FLORESTA da

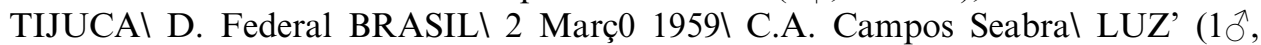
DZUP); 'COLEÇÃO $\backslash$ CAMPOS SEABRA' 'FLORESTA da TIJUCA\ D. Federal BRASIL\} 1 1 \text { Fevereiro 1960\ C.A.C. Seabra\ Luz' (19, DZUP); 'DPT } { } ^ { \circ } \text { ZOOL\UF- } PARANÁ' 'FLORESTA TIJUCA-RJ $\backslash$ BRASIL 17/I/61\ F.M. Oliveira leg.' (1q, 
DZUP); 'D. Federal $\backslash$ I. Governador $\backslash$ II-956 F. Perreira' (19, MZUSP); 'BRASIL: RJ $\backslash$ Maricá, 5m\ 12-15.i.1985\ V.O. Becker' 'sp.5' (4ㅇ, DZUP); 'COLEÇÃO\ CAMPOS SEABRA' 'REPRESSA RIO GRANDEI Guanabara Brasill IX.1960। F.M. Oliveira'(2ᄋ, DZUP); 'COLEÇÃO\CAMPOS SEABRA' 'REPRESSA RIO GRANDE\ Guanabara Brasil $\backslash$ 17-X-1960\ F.M. Oliveira'(1 9 , DZUP); 'COLEÇÃO\} CAMPOS SEABRA' 'REPRESSA RIO GRANDE\ Guanabara Brasil\ 18-XI-1960। F.M. Oliveira'(1 9 , DZUP); 'COLEÇÃO $\backslash$ CAMPOS SEABRA' 'REPRESSA RIO GRANDE\ Guanabara Brasil\XII-1960\ F.M. Oliveira'(5 9 , DZUP); 'COLEÇÃO\ CAMPOS SEABRA' 'REPRESSA RIO GRANDE\ Guanabara Brasill Dezembro 1960\ F.M. Oliveira' (6̊,1ठ̄, DZUP); 'COLEÇÃO। CAMPOS SEABRA' 'REPRESSA RIO GRANDEl Guanabara Brasil II-1961\ F.M. Oliveira' (1今̄, DZUP); 'Itatiaial R. Janeiro, Brasill abril 1961\ F.M. Oliveira' (6へ,, DZUP); 'COLEÇÃO\CAMPOS SEABRA' 'Itatiaia\R. Janeiro, Brasill Janeiro 1959\Z.V.

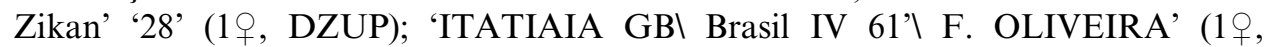
DZUP); 'DPT' ZOOL\ UF-PARANÁ' 'P.N. ITATIAIA-RJ` BRASIL-8/9/1967\ M. Alvarenga leg' (1, DZUP); 'J.F. Zikan\ITATIAYA, 700m\ Est. do Rio. Brasil\ 8.II.1946' (19, INPA); 'D”J.F. Zikan\ITATIAYA, 700m\5.VI.1941\E. Rio-Brasil.' (19, DZUP); ' $\circ$ ' 'J.F. Zikan\ITATIAYA, 700m\ E. Rio-Brazil\ 26XII-1929\Unha de boi' (19, DZUP);'Est. do Rio\ Angra dos Reis $\backslash 28 . I X .1951 \backslash$ L. Trav. F ${ }^{\circ}$ COL' (1, DZUP); 'Est. do Rio\ Angra dos Reis $\backslash 28 . I X .1951 \backslash$ L.Trav. F ${ }^{\circ}$ COL' (1 9 , MZUSP); 'BRASIL, RJ, Macaé PN\ Jumbatiba, 01.v.2007, 3 m\ 221640S - 414135W, J.A.I Rafael \& F.F. Xavier F', luz' (10̄', DZUP); 'COLEÇÃO। CAMPOS SEABRA' 'Guaratibal D. Fed. Brasil Outubro $1958 \backslash$ Aristoteles Silva' (1ㅇ, DZUP); '18-21/I/1996\CEDAE, 550m, \CACHOEIRA DE MACACU, RJ O. C. MIELKE \& MIERS leg.' (4q,1ठ̄, DZUP); 'Serra dos Orgãos 11.1940 Parko' (1q, DZUP). Rondônia: 'BRASIL:RO\ Ariquemes\180m 13-\ 16.iv.1989\ V.O. Becker' (5o, DZUP); 'BRASIL: RO\ Ariquemes\ 180m 13-I 16.iv.1989\ V.O. Becker' (19, DZUP); 'BRASIL, RO, Guajará-\ Mirim, R. Pacaás Novos $111113 \mathrm{~S}$ -645121W, Luz 07.ix.1999, U. Barbosa' (19, INPA); 'Brasil, RO, Itapuã do Oeste, Flonal do Jamari, $110 \mathrm{~m} \backslash 9.260^{\circ} \mathrm{S} 62.913^{\circ} \mathrm{W} \backslash 4 . i x .2012$, Cavichioli Melo, Rosa \& Santos' 'Armadilhal Luminosa' (4ㅇ, 2^ DZUP); 'Brasil, RO, Itapuãl do Oeste, Flonal do Jamari, $90 \mathrm{~m} \backslash 9.146^{\circ} \mathrm{S} 63.012^{\circ} \mathrm{W} \backslash$ 5.ix.2012, Cavichiolil Melo, Rosa \& Santos' 'Armadilhal Luminosa' (4, 2ð DZUP). 'BRASIL: Rondônial Ouro Preto do Oeste \9-III-1985 equipe J.R. Arias $\backslash$ CDCl 1m' '10' (1+, INPA); 'BRASIL: RO Porto Velho, $180 \mathrm{~m} \backslash 24-30 . i v .1989 \backslash$ V.O. Becker col' (2q, DZUP); 'BRASIL: RO\ Porto Velho, $180 \mathrm{~m} \backslash 2$-12.v.1989 V.O. Becker' (2q, DZUP); 'BRASIL:RO\ Porto Velho, 180m\2-12.v.1989\ V.O. Becker' (1, DZUP); 'BRASIL, RO, Vilhenal

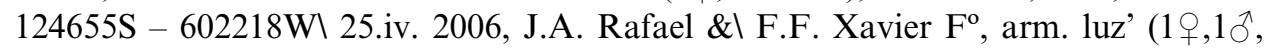
INPA); 'BRASIL: BRASIL: Rondônial Vilhenal 27-VII-1983\ Binda Leonete' 'ARM. MALAISE $\backslash$ C. AbERTO' 'Polo Noroeste' (2q, INPA); 'Rio Jamary 4 15-

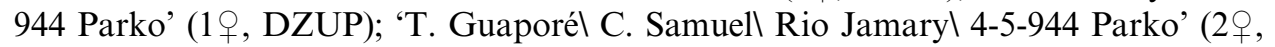
DZUP); 'Guaporél Porto-Velho' '(verso: XII-1944l A. Parko)' (19, DZUP); 'Rondônial Vilhenal 27-VII-1983। Binda Leonete' 'ARM. MALAISEl C. AbERTO' 'Polo Noroeste' (1ठ̃, INPA); 'BRASIL, RO, Vilhenal 124655S 602218W 25.iv.2008, J.A. Rafael \&l F.F. Xavier F'o arm.luz'; 'V. Rondônia (378

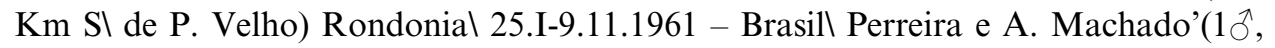
MZUSP). Roraima: 'Brasil, Roraima, Amajaril Tepequém, Igarapé da Lual 0347’00.5”N 6144’52.6’W’ ‘615m 02-jul-09 GamalNeto, J.L. Em Pensilvânia' 'MIRR 


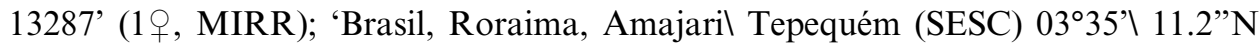
6142'53.7”W 630m' '16-abr-09 Gama Neto, J.L.I Pensilvânia' 'MIRR 12371' (1옹, MIRR); Brasil, RR, Guaporél 12¹6’05”S $\backslash 60^{\circ} 42^{\prime} 30^{\prime} \mathrm{W} \backslash$ 23.IV.2006 LUZI J.A. Rafael leg.'; 'Posto MEVA: Rio Auaris $\backslash$ Terr. Roraima, Brasil $4^{\circ} 8^{\prime} \mathrm{N} 64^{\circ} 29^{\prime} \mathrm{W} \backslash 31 /$ março/1977' 'Luzl Negra' (2 9 , INPA). 'Brasil, Roraima, Pacaraima,। Ramal do Miang $04^{\circ} \backslash 29^{\prime} 37^{\prime \prime} \mathrm{N} 61^{\circ} 04$ ’35'W 770m' ‘10-jul-08 Silva,S.J.R. da Silva Em\ isca aromática' 'MIRR 10290' (1q, MIRR). Santa Catarina: 'BRASIL: SCl Brusque, $100 \mathrm{~m} \backslash 5 . \mathrm{I} .1989 \backslash$ V.O. Becker col' $(2 q, 1 \hat{\jmath}$, DZUP); 'DPT' ZOOL\UF-PARANÁ' 'JOINVILLE-SCl BRASIL-9/2/69\ Mielke-Laroca' 'à luz' (10̂, DZUP); 'DPT ZOOLI UF-PARANÁ' 'JOINVILLE-SCl BRASIL-9/X/69\ Mielke-Laroca' (1ㅇ, DZUP). São Paulo: 'BRASIL - São Paulo,। Juquiá, Faz. Poço Grande,। 6-9iv.1940 - F. Lane \& Trav. Fo. \& C. Carvalho.' 'BRASIL - S. Paulol Juquiá, klm.

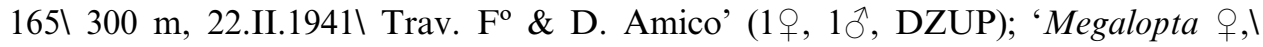
idalia $\backslash$ Smith $\backslash$ P. Moure det.40' '102.879' (1ㅇ, MZUSP); 'Brasil, São Paulo, 43 km a

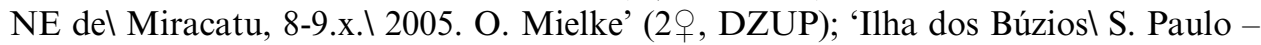
Brasil\ 16.X.-4.XI.963\ Exp. Dep.Zool.' (4ㅇ, DZUP); 'Ilha dos Búzios $\backslash$ S. Paulo Brasil\ 16.X.-4.XI.963\ Exp. Dep.Zool.' 'À luz' (5q, DZUP); 'Ilha dos Búzios $S$. Paulo - Brasil\ 16.X.-4.XI.963\ Exp. Dep.Zool.' 'À luz' (9, MZUSP); 'Macaubal, SP, Brasil $\backslash 16 /$ VIII/07\ $2^{\mathrm{a}}$ arm. - pretal sp 658' (1ㅇ, DZUP); 'Macaubal, SP, Brasill 20/XII/07\ $2^{\mathrm{a}}$ arm. - pretal sp 331' (1ㅇ, DZUP); 'Praia Palmeira\ SP. II-1963\ EXP.

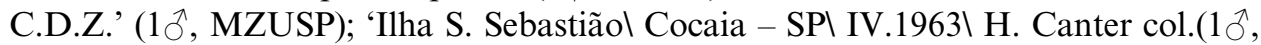

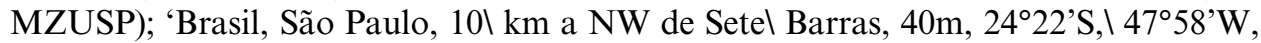
26.iii.2005,\ armadilha luminosa' (1ठ̄, DZUP); 'Faz. Pau D'Alho\Itú - São Paulol Brasil\XII-1960\U. Martins\ col.' (1+, MZUSP); 'Ribeirão Grande, SP\ Fazenda Intervales\20.v.1993 - luzl CGFroehlich leg.' (19,1§ึ, DZUP). ECUADOR: Sucumbios: 'ECUADOR\ PROV. NAPO\LIMONCOCHA\ 9 - JUNIO - 84\ Y. Carvajal' (1 9 , DZUP). PERU: Cuzco: 'PERU, CU, Campanentol Paratori 1203/ $7258 \backslash 690 \mathrm{~m}$ 22.X.2002\J. Grados' 'LIGHTTRAP\ MV/UV' (2q, MUSM); 'PERU, CU, Campanento\ Paratori 1203/7258\690m 23.X.2002\J. Grados' 'LIGHTTRAP\ MV/UV' (3, MUSM); 'PERU, CU, Campanentol Paratori 1203/7258\690m 24.

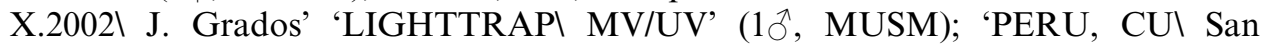

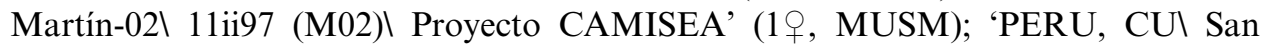
Martín-02\12v97 (M02)\Proyecto CAMISEA' (10̄, MUSM); ' PERU, CU, La Convención,\Echarate, CC, Timpial 7249’29’ /1207’14.20`\445m 18-19.x.2009 Light\ M. Alvarado y E. Razuri' (19, MUSM); 'PERU, CU, La Convención,। Echarate, CC, Otsanampiato, $\backslash 73^{\circ} 08^{\prime} 57,71^{\prime} / 12^{\circ} 39^{\prime} 31,36^{\prime} \backslash 1449 \mathrm{~m} \backslash 19 . x .2009$. Light

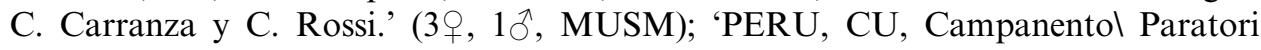
1203/7258\690m 23.X.2002\ J. Grados' ' LIGHTTRAP\MV/UV' 'Megalopta' (1ㅇ, MUSM); 'Peru, Cuzco, 3km NE\ de Quincemil, $613 \mathrm{~m}, \backslash 13.218^{\circ} \mathrm{S} 70.728^{\circ} \mathrm{W}, \backslash 20$.

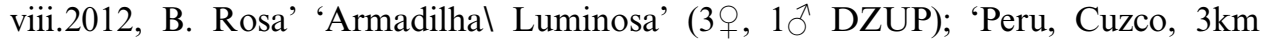
$\mathrm{NE} \backslash$ de Quincemil, $613 \mathrm{~m}, \backslash 13.218^{\circ} \mathrm{S} 70.728^{\circ} \mathrm{W}, \backslash 20$.viii.2012, L. Santos' 'Armadilhal

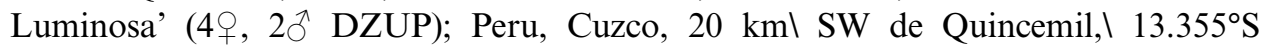
$70.889^{\circ} \mathrm{W}, \backslash$ 985m, 23.viii.2012,\ Cavichioli, Melo,\ Rosa \& Santos' 'Armadilhal Luminosa' (1 9, DZUP). Huanuco:'Bosque Nacional del Iparia, Rio Pachitea,\HU, PERU 300m\ 4-6.ix.74 G. Lamas' 'Megalopta' (1, MUSM); 'Tingo MarialPeru670ms' (19, DZUP). Junin: 'PERU: JU, Pampal Hermosa lodge, $\backslash 10^{\circ} 59^{\prime} \mathrm{S} / 75^{\circ} 25 \mathrm{~W}$, 1220m\25.xi.2007 J. Heppner' (19, MUSM); 'SATIPO-PERU\ $750 \mathrm{Mr} \backslash$ Coll. J. Lindemans' (2o, RMNH); 'SATIPO-PERUI 750 Mr Jan\1949' (4, RMNH); 
'SATIPO-PERU\ $750 \mathrm{Mr} \backslash$ febr. 1949' (19, RMNH); 'SATIPO-PERU $750 \mathrm{Mr}$ \1.1949' (2ᄋ, RMNH); 'SATIPO-PERU 750 Mr 112.1948' (1\%, RMNH); 'SATIPO-PERU 750 Mr \12.11.1938\Coll J. Lindemans' (1 $q$, RMNH). Loreto: 'PERU, LO, Maynas \Albergue AE tours $\backslash$ S4 18,68 W73 13,91\v01 Mario Callegaril

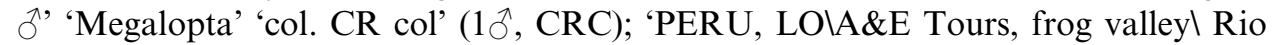
Tahuayol 27vi01 Mario Callegari' 'Ex. light trap' 'col. CR col' (1+, CRC); 'Santa Sofia, Rio Utoquinia, LO, PERU 29-31.viii.74\ G. Lamas' 'Megaloptal det. J.G. Rozen' (1, MUSM); 'Peru, LO, Maynas, Alpahuayo-Mishanal KM 28 - Ex light trap\12vii01 Mario Callegari' 'Megalopta' ‘col. CR col' (1웅 CRC). Madre de Dios:'Peru, Madre de Dios, $\backslash 6 \mathrm{~km}$ a NE de Mazuko, $\backslash 13.048^{\circ} \mathrm{S} 70.346^{\circ} \mathrm{W}, \backslash 380 \mathrm{~m}$, 18.viii.2012,\Cavichioli, Melo, Rosal \& Santos' 'Armadilhal Luminosa' (7오 $20^{\wedge}$ DZUP); 'Peru, Madre de Dios $\backslash$ Manu, $9 \mathrm{~km}$ a SW del Mazuko, 364m, $\backslash 13.181^{\circ} \mathrm{S}$ 70.384 W,\19.viii.2012, Cavichioli, \Melo, Rosa \& Santos' 'Armadilha\ Luminosa' (3ㅇ, $5 \delta^{\circ}$ DZUP); 'Peru, Madre de Dios, \ Manu, $9 \mathrm{~km}$ a SW del Mazuko, 364m,I $13.181^{\circ} \mathrm{S}, 70.384^{\circ} \mathrm{W}, \backslash$ 19.viii.2012,। R. Cavichioli' 'Armadilhal Luminosa' (4ㅇ, DZUP); 'Peru, Madre de Dios, $\backslash 5 \mathrm{~km}$ SW de St. Rosa, $12.967^{\circ} \mathrm{S} 70.332^{\circ} \mathrm{W}, \backslash 404 \mathrm{~m}$, 21.viii.2012,\ R. Cavichioli' 'Armadilha\ Luminosa' (8ㅇ, 10 DZUP). 'PERU, MD, Tamboata\ Jungle Lodge, 225 masl $\backslash$ S12 49,456 N69 24, 163\ 9-20x01, C Rasmussen leg' 'col. CR col' (1ð̄, CRC); 'PERU, MD, Boca Riol La Torre 300m\27.xi.79 G. Lamas' (1 9, MUSM); 'Tambopatal 23.jun.84' (1 9, MUSM); 'PERU, MD, 15 Km E\ Pto, Maldonado 200m\4/2/90 M. MEDINA' (1 9 , MUSM). Pasco: 'PERU, PA,

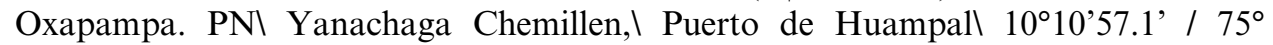
34'25.6’ 1001m 06-09.xi.2010 C. Caramaza y J. Peralta' (1 9 , MUSM); 'PERU: DPTO. Pasco:\ Paujil (P.N. Yanachaga)\ 20.IX.93 (500mt.)\ Pedro Hocking' 'Megalopta' (19, MUSM); 'PERU: Dpto Pasco:\Sta. Rosa (R. Palcazu) $\$ 5.XI.89 (500mt)\ Pedro Hocking' (1q, MUSM); 'PERU: Dpto Pasco:\ Sta. Rosa (R. Palcazu)\28.IX.92 (500mt)\ Pedro Hocking' (1+9, MUSM). Puno: 'Peru, Puno, Carabaya, $\backslash 11 \mathrm{~km}$ ao $\mathrm{S}$ de Mazuko, $\backslash 13.206^{\circ} \mathrm{S} 70.368^{\circ} \mathrm{W}, \backslash 450 \mathrm{~m}, 19$. viii.2012,। Melo, Rosa \& Santos' 'Armadilhal Luminosa' (2+, 4 $\overbrace{}^{\wedge}$ DZUP). San Martin: 'PERU, SM, Tarapoto-\Yurimaguas, km 20\ 'BIODIVERSIDAD'` 0634/7620 950 masl\IV-VI.2002 C. Rasmussen' 'Megalopta sp' 'col. CR col' (1ㅇ, CRC); 'Ijarigi 320m\ Rio Pachiteal1.III.68\ Col: R. Garcia' 'Megalopta' (19, MUSM). SURINAME: Brokopondo: 'Surinamel Brokopondo\ March 1964\ M. Boeseman $(1$,, $\mathrm{RMNH})$ '. Nickerie: 'Museum Leiden\W. Suriname Exp.\ Maratakka River\ Awarre-savannal 26.II-3.III.1971\ D.C. Geijskes' (1, RMNH)'. Paramaribo: 'Surinamel Paramaribol Ma Retraitel Swamp forestl 18-20 Jan. 1964l D.C. Geijskes' 'MALAISE-TRAP' (1, RMNH)'; 'Surinamel Paramaribol Ma Retraitel Swamp forest $\backslash$ 20-23 mar. 1964\ D.C. Geijskes' 'MALAISE-TRAP' (19, RMNH)'. Saramacca: 'Suriname, Coppename River\ Voltz Mountain\13-15 July 1963\ P.H.v. Doesburg Jr. (1 9, RMNH)'. Sipaliwini: 'Suriname Coopename 24 Febr 1965 P.A. Florschützl \& P.J.M. Maas' 'at light' (1+, RMNH)'. VENEZUELA: Amazonas: 'VENEZUELA, Amaz.। Pro. Ayacuchol 25 IV 1967 R. L. Dressler' (1+, DZUP). 